\title{
A Study of Unconventional Gas Accumulation in Dannevirke Series (Paleogene) Rocks, Canterbury Basin, New Zealand.
}

A thesis submitted for the fulfilment of the degree of Master of Science, majoring in Petroleum Geoscience.

School of Geography, Environment \& Earth Sciences,

Victoria University of Wellington,

New Zealand. 


\section{Abstract}

This thesis aims to assess the potential of unconventional gas accumulation of Dannevirke aged (65-43 Ma) mudrock of the Canterbury Basin, South Island, New Zealand. Unconventional hydrocarbon resources contained in low-porosity, low-permeability rocks are potentially a large source of natural gas. Recent developments throughout the United States and increasingly so in Australia, signify a shift in exploration efforts from conventional natural gas targets towards unconventional shale gas plays and basin centred gas systems. Despite extensive international progress made in this field of exploration, little is known about New Zealand unconventional hydrocarbon systems.

The Canterbury Basin is approximately $360,000 \mathrm{~km}^{2}$ in area and is located approximately between $44^{\circ} \mathrm{S}$ and $46^{\circ} \mathrm{S}$. The deepest part of the basin is located offshore and is known as the Clipper Sub-Basin, which exhibits economic basement depths of $6500 \mathrm{~m}$. The Clipper Sub-Basin is a late Cretaceous syn-rift horst and graben feature which trends north east-south west and is bound basinward by the Benreoch High and landward by the Canterbury Bight High. Dannevirke aged transgressive rocks overlay these structures and intermittently exhibit gas-charged intervals in low porosity facies.

Elevated gas concentrations are recorded in four exploration wells in the Clipper Sub-Basin from gas chromatograph readings (up to 2.7/00.4\%). These high-gas zones correspond to intervals of elevated quartz (up to $72 \mathrm{wt} \%$ ), whereas non-gaseous intervals corresponded to quartz values as low as $30 \mathrm{wt} \%$. Scanning electron microscopy results do not reveal biogenic silica populations in the cutting samples examined. High silica is related to diagenetic silica transformations of mica, various clay minerals, pyrite and silica transformations. Although no visible porosity is observed in thin sections, FMI wireline analysis illustrate natural fractures predominately occur in siliceous intervals, where resistive fractures can account up to one fracture per $10 \mathrm{~m}$ of stratigraphic thickness. These fissile or laminated brittle lithologies are likely hydrocarbon conduits or accumulation intervals for wet gas. RockEval pyrolysis results indicate the siliceous mudrocks are organic lean, comprising an immature gas-prone source rock which averages 1.5\% total organic carbon.

Findings made in this research are compared to the Whangai Formation, considered in this study to be a comparable shale gas system and also to the Monterey Formation of the United States which is a known basin centred gas system. Dannevirke aged sediments found in the Clipper Sub-Basin appear to constitute the requisites of a near-to-source, direct type, basin centred gas system. Implications of this study open up the possibility that New Zealand's widespread Paleocene-Eocene mudrocks are capable of natural gas accumulation and therefore viable natural gas exploration targets in New Zealand. 


\section{Acknowledgments}

This Master of Science thesis would not have been completed without the kind and positive assistance of my many friends, colleagues and most importantly my parents, Jean and Peter Cozens.

I would like to thank the very helpful assistance of, Peter Hazledine, Hilary Dussing, Jonathan Salo, Richard and Beryl Newman, Kim Styles, Tim Stern, Gary Ward, Vaughan Stagpoole, Geoff Clitheroe, Bede Browne, Stewart Bush, Trev Maltby, David Flynn, Hugh Morgans, Dan Willmott, Dominic Mahoney, Hamish White, Chris Newman, Graham Hill, Brad Field, Mark Lawrence, Richard Sykes, Georgie Henderson, Grant Caldwell and Stewart Bennie. Your collective support either academic or emotional throughout the difficult year I faced in 2010 is reflected in every page of this thesis.

Excellent guidance and thorough geological tuition has come care of my three supervisors, Mac Beggs, Greg Browne and Mike Hannah. Your initiation of this research, meticulous proof reading and ongoing momentum in search of this unconventional glut is truly appreciated. Any remaining faults in the text are mine.

“If I had more time, I would have written less” Mark Twain 1835 - 1910. 


\section{Table of Contents}

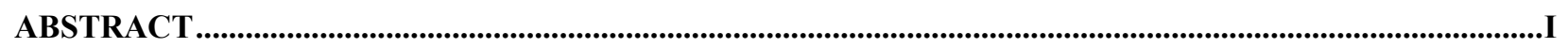

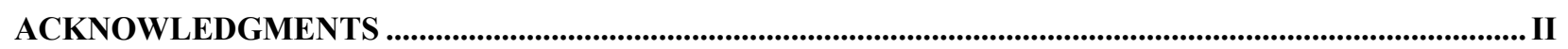

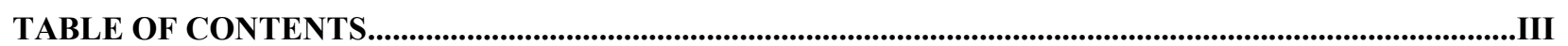

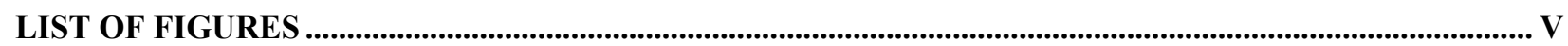

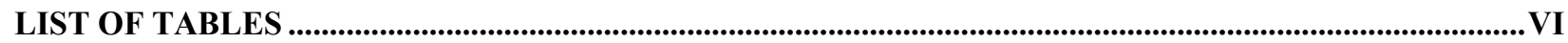

LIST OF EQUATIONS ................................................................................................................................................

1.0 INTRODUCTION.......................................................................................................................................... 1

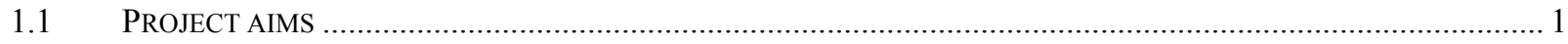

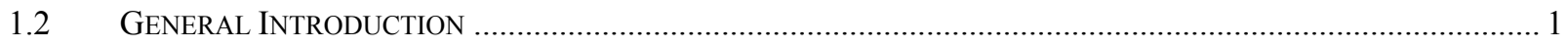

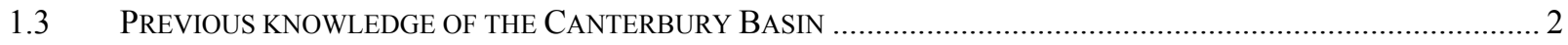

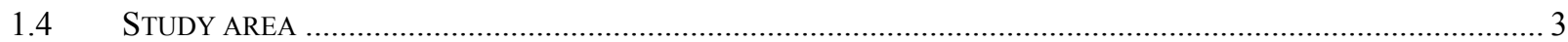

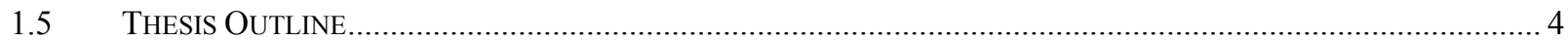



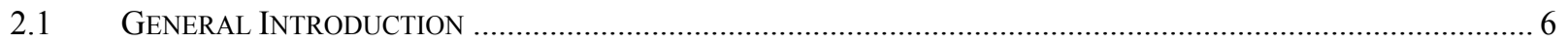

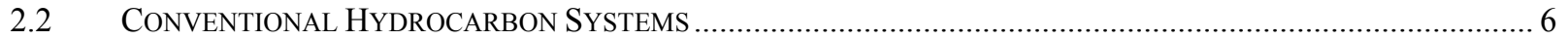

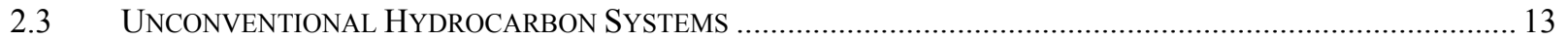

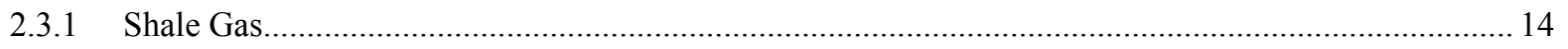

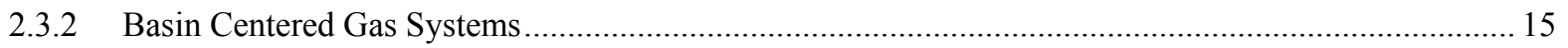

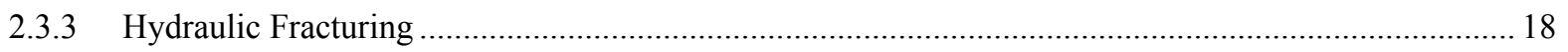

3.0 GEOLOGICAL SETTING OF THE CANTERBURY BASIN \& CLIPPER SUB-BASIN .................... 20

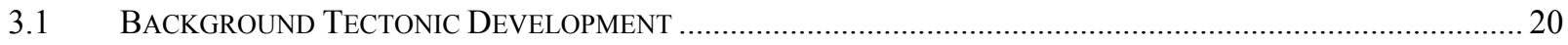

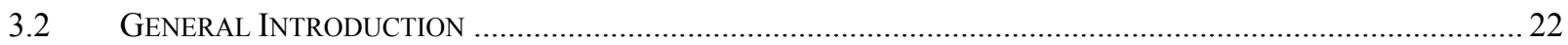

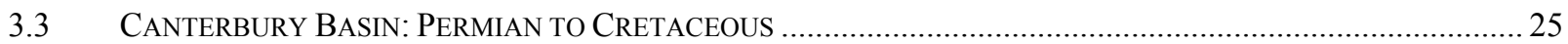

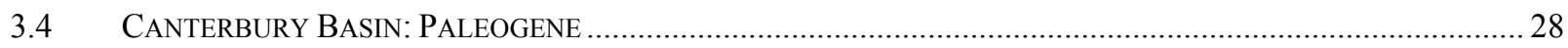

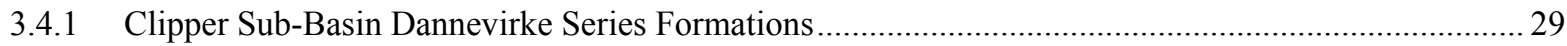

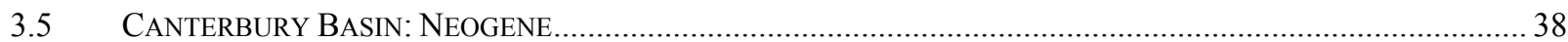

4.0 STUDY METHODS.................................................................................................................................... 40

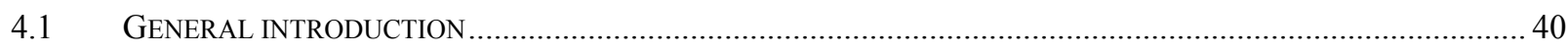

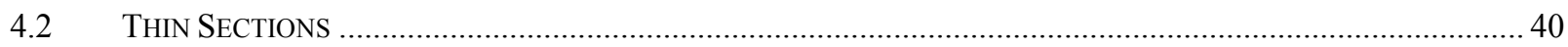

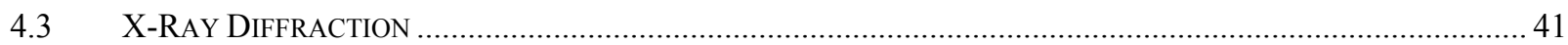

4.4 SCANNING ELECTRON MiCRosCoPe AND ENERGy DiSPERSIVE SPECTROSCOPY ......................................... 42

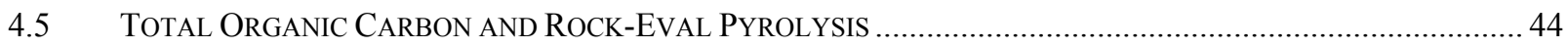

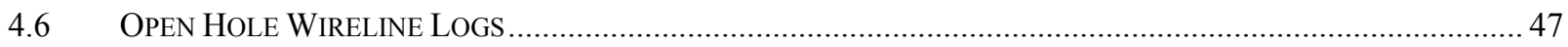

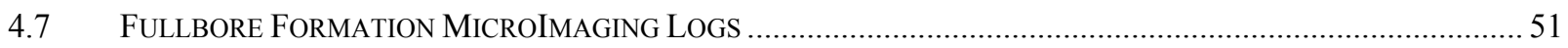

5.0 RESULTS AND INTERPRETATION OF LABORATORY BASED DATA .........................................56

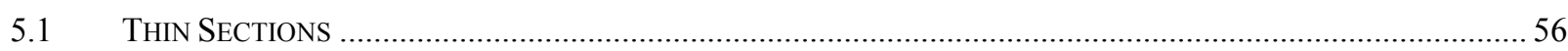

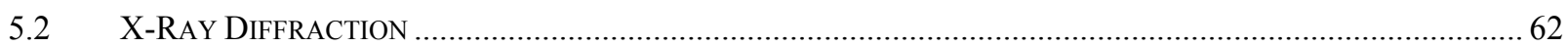

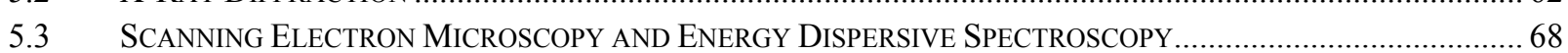

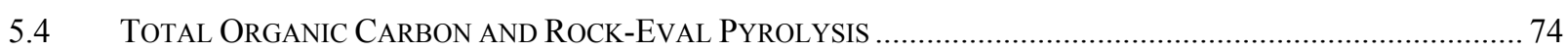

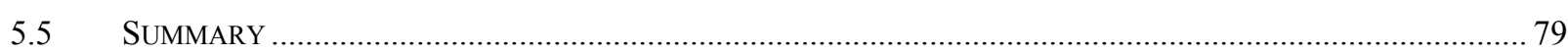

6.0 RESULTS AND INTERPRETATION OF WELL BASED DATA.................................................... 81

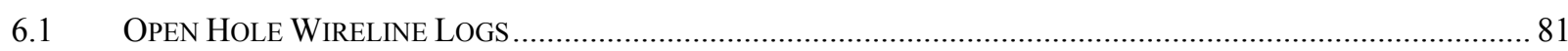




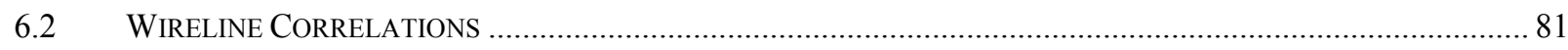

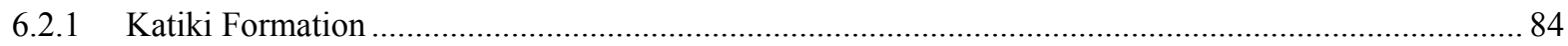

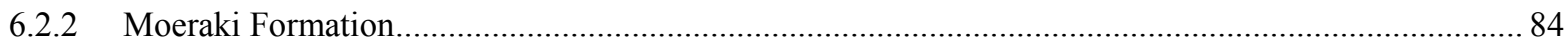

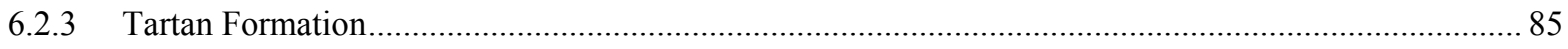

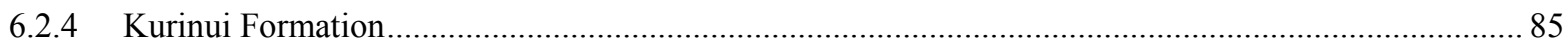

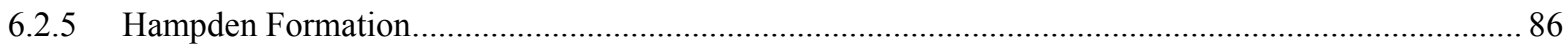

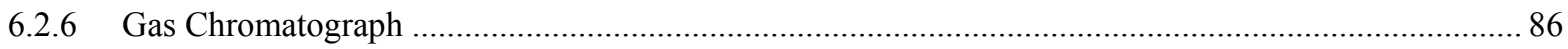

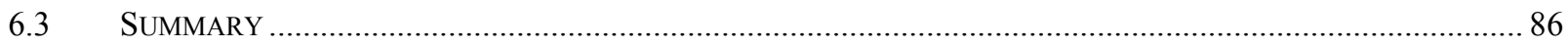

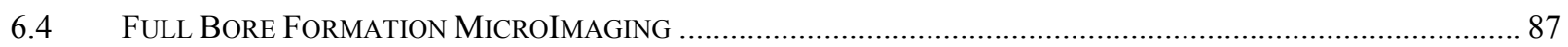

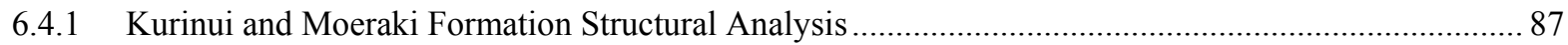

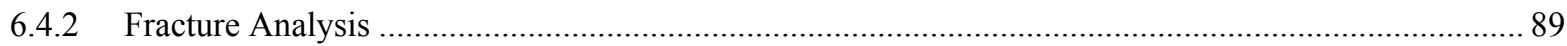

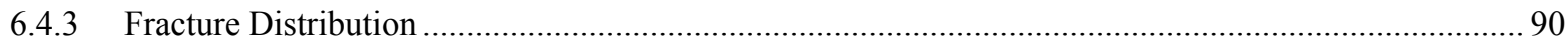

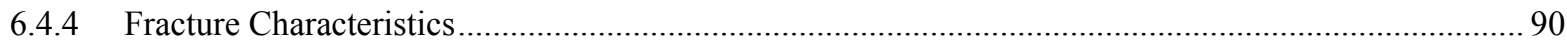

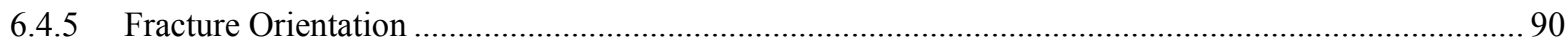

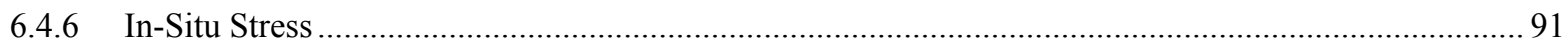

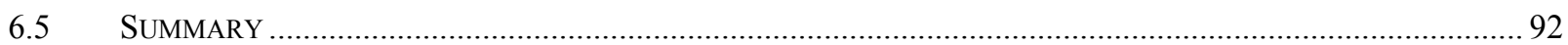

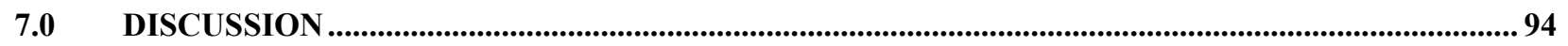

INTRODUCTION

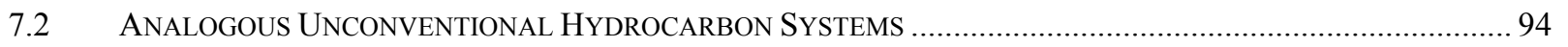



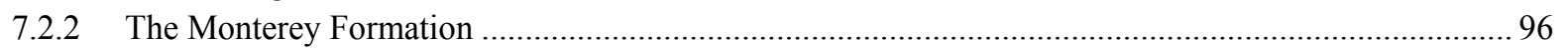

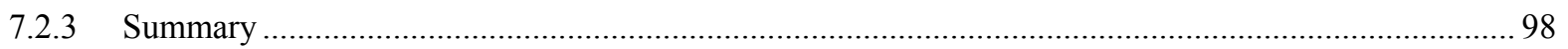

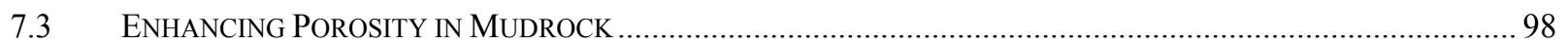

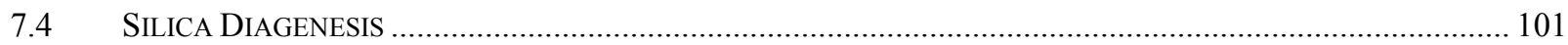

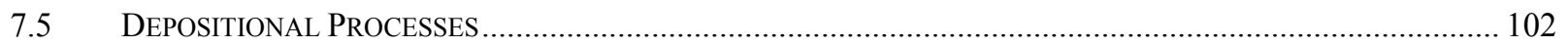

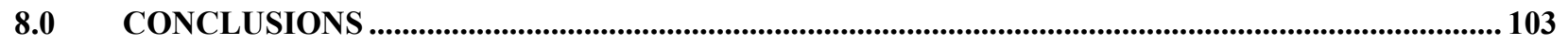

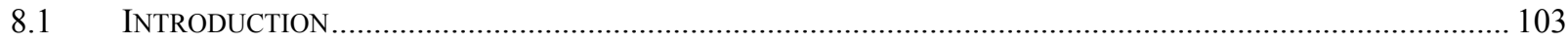

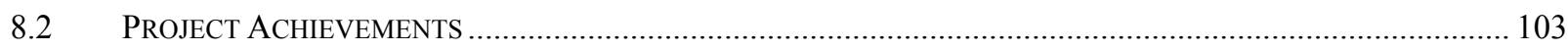

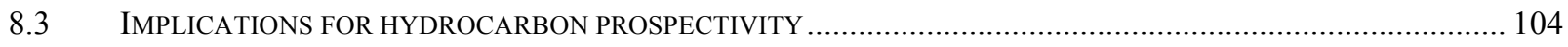

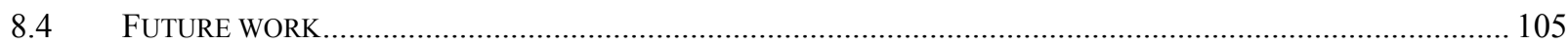

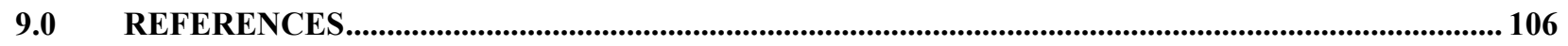

APPENDIX A: NEW ZEALAND GEOLOGICAL TIMESCALE ..............................................................114

APPENDIX B: WIRELINE ABBREVIATIONS \& OIL FIELD GLOSSARY ........................................... 116

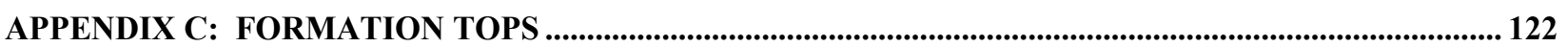

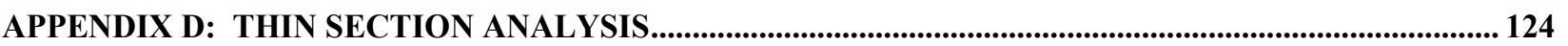

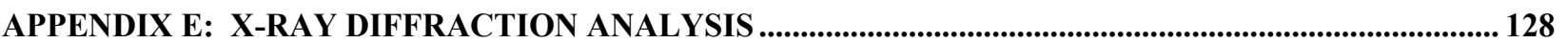

APPENDIX F: SCANNING ELECTRON MICROSCOPY \& ENERGY DISPERSIVE SPECTROSCOPY

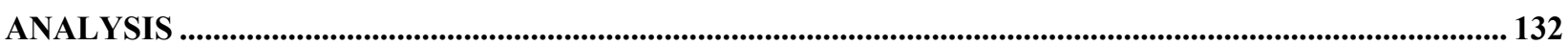

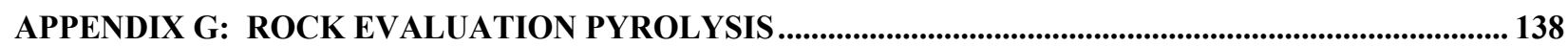

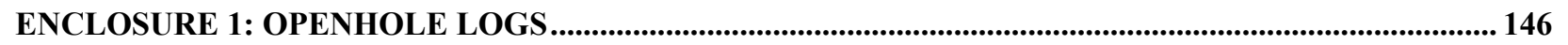

ENCLOSURE 2: FULLBORE MICROIMAGING LOG............................................................................. 146

ENCLOSURE 3: FULLBORE MICROIMAGING QC LOGS...................................................................... 146 


\section{List of Figures}

Figure 1.1: Canterbury Basin: Location of study area.................................................................................................. 4

Figure 2.1: Van Krevelen diagram and oil generation window. .................................................................................... 8

Figure 2.2: Migration of hydrocarbon between clastic sand sized grains....................................................................... 9

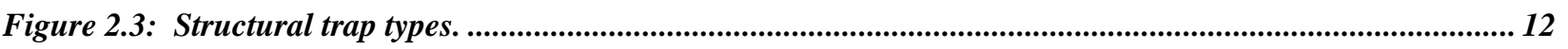

Figure 2.4: Schematic hydrocarbon systems........................................................................................................... 13

Figure 2.5: Elements of a shale gas play. ........................................................................................................................ 15

Figure 3.1: New Zealand: Map of tectonostratigraphic terranes............................................................................. 22

Figure 3.2: Canterbury Basin: Chronostratigraphic Model. ................................................................................ 24

Figure 3.3: Canterbury Basin: Lower Clarence Series paleogeography. ................................................................. 26

Figure 3.4: Canterbury Basin: Lower Ruakumara Series paleogeography.............................................................. 27

Figure 3.5: Canterbury Basin: Mid to late Cretaceous isopach map.................................................................... 28

Figure 3.6: Clipper Sub-Basin: Generalised well stratigraphy. ........................................................................ 30

Figure 3.7: Canterbury Basin: Lower Mata Series paleogeography. ...................................................................... 31

Figure 3.8: Canterbury Basin: Lower Dannevirke Series paleogeography............................................................ 32

Figure 3.9: Canterbury Basin: Middle Dannevirke Series paleogeography............................................................... 34

Figure 3.10: Canterbury Basin: Lower Arnold Series paleogeography..................................................................... 35

Figure 3.11: Canterbury Basin: Upper Arnold Series paleogeography..................................................................... 36

Figure 3.12: Canterbury Basin: Lower Landon Series paleogeography. .................................................................. 37

Figure 3.13: Canterbury Basin: Paleogene isopach map......................................................................................... 38

Figure 3.14: Canterbury Basin: Neogene isopach map. ........................................................................................ 39

Figure 4.1: Source Rock Analyser (SRA) programme. ……......................................................................................... 45

Figure 4.2: Schematic theory underlying fracture sinusoids. ..................................................................................... 52

Figure 4.3: Drilling Induced Tensile Fractures (DITF) and shear failure fracture schematic.............................. 54

Figure 4.4: Cutter-1: Examples of FMI analysis using Petris Recall Version 5.3 software.................................... 55

Figure 5.1: Cutter-1: Thin section of cutting sample 2600 mbrt............................................................................... 57

Figure 5.2: Galleon-1: Thin section of cutting sample 2450 mbrt............................................................................. 58

Figure 5.3: Cutter-1: Thin section of cutting sample 2530 mbrt............................................................................... 59

Figure 5.4: New Zealand: Permian to Paleogene Quartz-Feldspar-Lithic Composition Plot.................................. 61

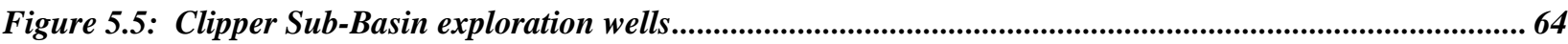

Figure 5.6. Clipper Sub-Basin exploration wells; Clipper-1 and Cutter-1 XRD diffraction curves. ........................ 65

Figure 5.7: Cutter-1: Abundance quartz/mixed layer clay vs. wireline relationship................................................ 67

Figure 5.8: Endeavour-1: 1600 mbrt subhedral to euhedral quartz grains determined using EDS....................... 69

Figure 5.9: Cutter-1: 2430 mbrt plates of kaolinite determined using EDS. ........................................................... 69

Figure 5.10: Clipper-1: 3000mbrt SEM image illustrating webbed or stringing smectite and illite...................... 70

Figure 5.11: Cutter-1: 2200 mbrt illite determined using EDS.......................................................................... 70

Figure 5.12: Galleon-1: 2400 mbrt SEM image illustrating mixed clay layers. ..................................................... 71

Figure 5.13: Clipper-1: 3000 mbrt SEM and EDS image. ............................................................................... 72

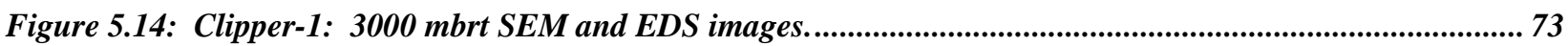

Figure 5.15: Cutter-1: Generative potential (quantity) as determined by $S_{2}$ vs. TOC cross plot.............................. 76

Figure 5.16: Canterbury Basin: Dannevirke Series Van Krevelen diagram. ............................................................ 77

Figure 6.1: Clipper Sub-Basin: Wireline well correlation. ...................................................................................... 83

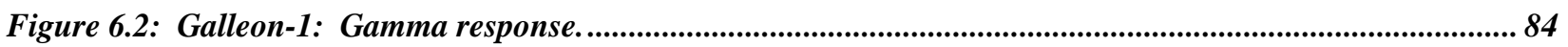

Figure 6.3: Cutter-1: Gas chromatograph readings. ............................................................................................. 85

Figure 6.4: Cutter-1: 2050 - 2600mbrt FMI walkout plot. ........................................................................................ 88

Figure 6.5: Cutter-1: Fracture orientation rose diagram.......................................................................................... 91

Figure 6.6: Cutter-1: DITF rose diagram and World Stress Map. .......................................................................... 92

Figure 7.1: Canterbury Basin: Fault and igneous induced deformation of Paleogene sediments...................... 100 


\section{List of Tables}

Table 2.1: Kerogen types present in a conventional petroleum system. ............................................................... 7

Table 2.2: Structural and stratigraphic hydrocarbon traps.......................................................................................... 11

Table 2.3: Direct and Indirect Basin Centred Gas System attributes.................................................................16

Table 2.4: Direct and Indirect Basin Centred Gas System phase evolution..........................................................17

Table 3.1: Clipper Sub-Basin: Summary of late Mata Series to early Arnold Series formation used in this thesis.

Table 4.1: Clipper Sub-Basin: Dannevirke Series thin section sample selection

Table 4.2: Clipper Sub-Basin: Dannevirke Series XRD sample selection. ..........................................................42

Table 4.3: Clipper Sub-Basin: Dannevirke Series XRD procedure settings. ......................................................... 42

Table 4.4: Clipper Sub-Basin: Dannevirke Series SEM \& EDS sample selection. ................................................ 44

Table 4.5: Clipper Sub-Basin: Dannevirke Series Rock Pyrolysis sample selection. ............................................. 47

Table 4.6: Clipper Sub-Basin: Dannevirke Series wireline logs run. ................................................................... 48

Table 4.7: Cutter-1: Dip types and definitions used in FMI interpretation. ....................................................... 53

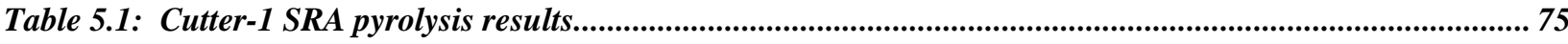

Table 5.2: Cutter-1: Generative potential (quantity) as determined by TOC analysis........................................... 75

Table 5.3: Cutter-1: Kerogen type and expelled products (quality) as determined by HI...................................... 77

Table 5.4: Cutter-1: Thermal maturity as determined by $T_{\max }\left({ }^{\circ} \mathrm{C}\right)$............................................................................. 79

Table 6.1: Cutter-1: 2050 - 2600mbrt showing FMI interpreted structural zones................................................... 89

Table 6.2: Cutter-1 2050 - 2600mbrt FMI interpreted natural fractures. .................................................................. 90

Table 7.1: Shale Gas \& BCGS Summary Table: East Coast New Zealand and Californian analogues................ 95

\section{List of Equations}

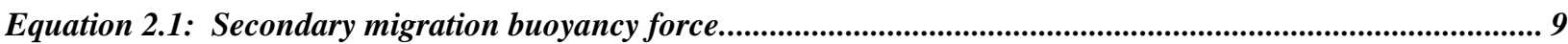

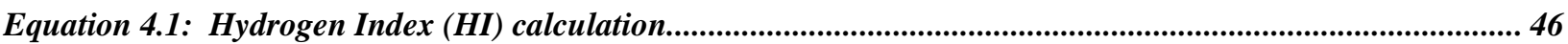

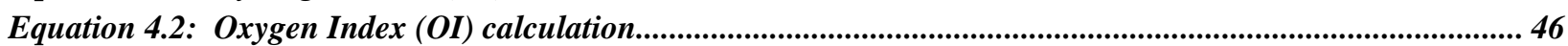

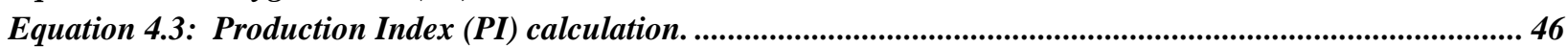

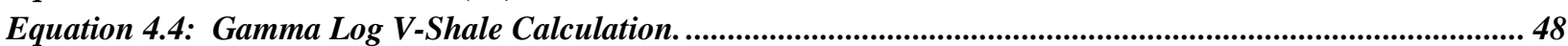

Equation 4.5: Density-Neutron Log V-Shale Calculation........................................................................................ 50 


\subsection{Introduction}

\subsection{Project aims}

Unconventional hydrocarbon resources contained in mudstone is potentially a large source of natural gas. Shale gas systems and Basin Centred Gas Systems (BCGS) are two unconventional resource types that have largely been overlooked by the 'traditional' or conventional oil and gas industry in New Zealand, although internationally their potential is gradually becoming better appreciated. Neither fine-grained sediments nor Dannevirke Series rocks of the Canterbury Basin have figured prominently in previous assessments of the petroleum potential of the Canterbury Basin.

This thesis aims to assess the potential and the possibility of unconventional gas accumulating in Paleocene and Eocene aged (Dannevirke Series 65-43Ma) mudstone in the Canterbury Basin, South Island, New Zealand. Global analogues illustrate mudstone has the ability to generate and accumulate economic quantities of natural gas. If this is the case, a study to determine the composition and organic geochemistry of the Canterbury Basin mudstone is required.

Thin section petrology, x-ray diffraction (XRD), scanning electron microscopy (SEM) techniques and wireline logs are used to determine the composition of strata where gas accumulation is known or suspected. Selected intervals were further subjected to source rock analysis to determine their hydrocarbon quality, quantity and maturity. This analytical approach assessed the controlling factors that either allowed or impeded natural gas accumulation in low porosity and low permeability mudrocks. Patterns and stratigraphic correlations from Clipper Sub-Basin exploration wells are recognised by examining indicative wireline signatures.

Results of this research are compared to known or suspected gas-charged mudstone from New Zealand's East Coast Basin and California's Santa Maria Basin. These findings may constitute the requisites of either a BCGS or shale gas system not previously known to exist in New Zealand, but well documented in the United States gas fields.

\subsection{General Introduction}

The late Cretaceous to Paleogene period in the Canterbury Basin is characterised by transgressive sedimentation, which commenced in the late Cretaceous (Haumurian) and continued through to early Oligocene (Whaingaroan) time (Field \& Browne, 1989). This period is also characterised by fluctuating global climate and ocean circulation patterns (c.a. 61-49 Ma), continued marine and terrestrial extinctions and, relative to present levels, heightened $\mathrm{CO}_{2}$ concentrations (Killops et al., 2000; Crouch \& Brinkhuis, 2005). In the offshore Clipper Sub-Basin, thick $(<1100 \mathrm{~m})$ successions of late Cretaceous to Paleogene, largely massive mudstones, drape the underlying syn-rift graben sandstones of the mid Cretaceous Period (e.g. Clipper Formation). 
The Dannevirke Series mudstones are known to be organic rich Gibbons \& Herridge, 1984; Gibbons \& Herridge, 1984; Killops et al., 1997). They exhibit variable stratigraphic thickness, are occasionally fissile or laminated, and are often located within short migration distances to known Cretaceous reservoirs of the Pukeiwahiti and Shag Point formations (Sykes \& Funnell, 2002; Morgans, 2009; Schiøler, et al., 2010).

The late Cretaceous to late Paleogene sediments of the Canterbury Basin has long been of interest to the oil industry. Five offshore wells have been drilled in the Canterbury Basin, two of which recorded and sampled gas condensate shows in the Cretaceous sediments at Galleon-1 and Clipper-1 (Hawkes \& Mound, 1984; Wilson, 1985). Although not sampled, the Cutter-1 well indicated anomolous gas shows in Eocene mudstones (Tap Oil Limited, 2007). Favourable organic rich mudstone formations such as the Katiki, Tartan, Moeraki and Kurinui exhibit excellent source rock potential and are laterally pervasive (Field \& Browne, 1989; Schiøler et al., 2008). These organic rich mudstones offer an unconventional resource and although considered high risk, which has hindered their exploration, it does not necessarily mean non-productive. Mudstones account for c.a. $70 \%$ of global basin fill and therefore influence a very large proportion of hydrocarbon generation and productivity (Alpin \& Macquaker, 2010). The term shale, which is commonly used to describe all fine grained sediments, must be used with caution as it implies fissility and preferential alignment of grains. Not all mudstones are finely laminated and will act more as flow barriers and seals to migrating hydrocarbon than shale, which is comprised of complex porous rocks (Hornby et al., 1994). The term shale gas is used for natural gas sourced from shale rock.

Lack of detailed understanding of the geological nature of shale gas resources has been an important factor in suppressing exploration outside of the United States (Law, 2002). Potentially one of the most economically important unconventional gas systems in the world BCGS contribute at least $15 \%$ of the total United States annual gas production (Law, 2002; The Economist, 2010). This thesis assumes a similar origin and occurrence of gas in tightly laminated or fissile mudstones contained in the Canterbury Basin, possibly constituting a realistic, near-term energy resource.

\subsection{Previous knowledge of the Canterbury Basin}

The hydrocarbon potential of the Canterbury Basin has provided the impetus for geological investigation since the 1900's (Field \& Browne, 1989). The first petroleum exploration well at Chertsey-1 was drilled in 1917. Gravity and magnetic surveys were first conducted in the Canterbury Basin during the mid 1960's by the Department of Scientific and Industrial Research (DSIR). Thousands of kilometres of seismic data have since been acquired by various oil companies; the majority between 1970 and 1985 targeting Cretaceous aged source rocks and Cretaceous to Miocene reservoir sandstones (e.g. Shell BP Todd Canterbury Services Ltd, 1984).

Previous hydrocarbon assessments have been focussed on Teurian Stage (Dt) and older source rock potential (Killops et al., 1997; Sykes \& Funnell, 2002). Although Gibbons \& Herridge (1984) and 
Gibbons \& Fry (1986) briefly examined Paleocene to Oligocene source rock potential from Clipper-1 and Galleon-1 respectively, there has been little research conducted in these mudstones since. Research by several authors is beginning to focus attention on Dannevirke age sediments in the North Otago region and the Canterbury Basin. Wilson \& McMillan, (1996) and McMillan, (1999) published two geological summaries of coastal Otago, which was advanced by Morgans (2009) who suggested the Hampden Beach section (located approximately $1 \mathrm{~km}$ north of Moeraki) represents one of the most complete Paleogene successions in New Zealand. Schiøler et al., (2010) highlights the Tartan Formation (observed in the Canterbury Basin) as having good to excellent source rock potential. Known to be laterally persistent, organic rich, exhibiting ultra low porosity and low permeability properties of variable thickness, the Tartan Formation may provide sufficient impetus to investigate the hydrocarbon potential of other formations within the Dannevirke Series.

\subsection{Study area}

The Canterbury Basin is located approximately between $44^{\circ} \mathrm{S}$ and $46^{\circ} \mathrm{S}$ latitude (Crown Minerals New Zealand, 2009). The total spatial dimensions are approximately $55,000 \mathrm{~km}^{2}$ extending from the onshore plains to an offshore region approximately $30,000 \mathrm{~km}^{2}$ in area southeast of the central South Island. The basin extends eastward of Oamaru nominally as far as the upper slope (e.g. the Bounty Trough). The study area of this research focuses on the Clipper Sub-Basin (Figure 1.1). In the Clipper Sub-Basin, depths to economic basement are up to $6500 \mathrm{~m}$, making it the deepest part of the Canterbury Basin (Crown Minerals New Zealand, 2009). It is an in-filled graben bounded to the southeast by the Benreoch High and to the northwest by the Canterbury Bight High. This study area was chosen for the following reasons:

1. A near continuous Paleocene - Eocene sedimentary record exists with excellent source rock potential (Killops et al., 1997; Morgans, 2009).

2. The Clipper Sub-Basin depth to economic basement is deep; a requisite for a BCGS (Law, 2002).

3. Anomalous saturated gas readings made in the Cutter-1 well drilled in 2006 (Tap Oil Limited, 2007) may indicate an unconventional gas play. Similar total gas chromatograph readings have been noted in Clipper Sub-Basin exploration wells, Endeavour-1, Galleon-1 and Clipper-1.

4. The Canterbury Basin is a known conventional hydrocarbon system (Field \& Browne, 1989). 


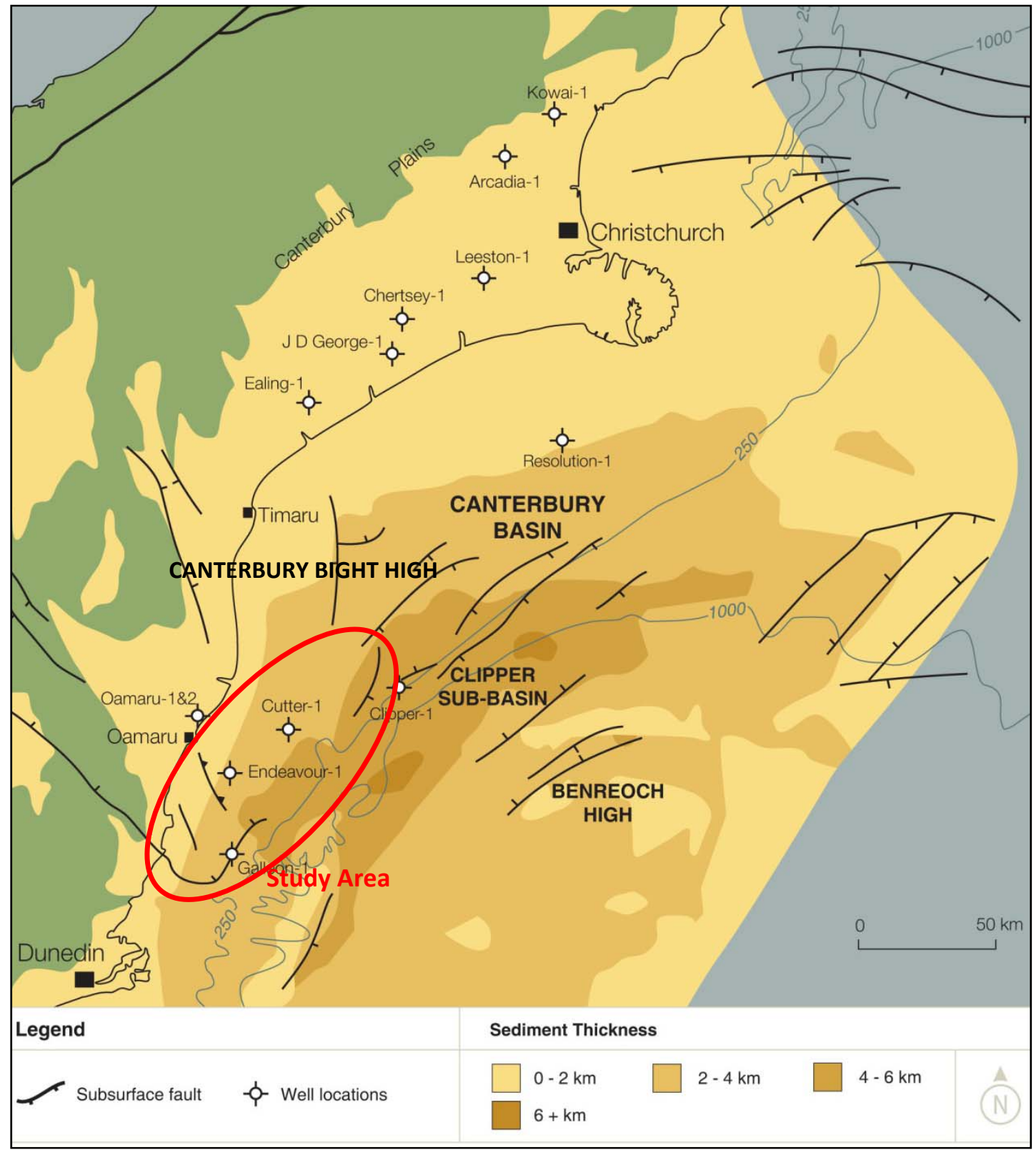

Figure 1.1: Canterbury Basin: Location of study area.

Illustrated are horst and graben features associated with Cretaceous syn-rifting. Exploration wells completed to date are illustrated, four of which are within the red oval; the study area of this research. Modified after Crown Minerals (2009).

\subsection{Thesis Outline}

This thesis is separated into eight chapters. Following this introduction outlining the aim and study area of this research, petroleum system concepts are discussed in Chapter 2. Concepts of conventional hydrocarbon exploration are outlined initially before a discussion of unconventional hydrocarbon exploration. Shale gas and BCGS are then discussed in this chapter. Chapter 3 investigates the geological model that has given rise to known petroleum systems of the Canterbury Basin. The chapter also outlines the geological evolution of the basin from the mid Cretaceous to present day with particular emphasis on the depositional environments which affect Dannevirke Series mudstones. A study methods section (Chapter 4) outlines the techniques used in this study. This includes laboratory and wireline log 
evaluation used to characterise known or suspected shale gas plays. Chapter 5 and 6 discusses analytical results and offers interpretation of the laboratory and well based data. Chapter 7 provides a discussion section where a case study investigates comparable Mata to Dannevirke aged mudstone deposition in the Whangai Formation of the East Coast Basin. The prolific Monterey Formation in the Santa Maria Basin, California is also compared, as an example of a producing fractured shale gas play. Chapter 8 , aside from concluding and summarising findings, briefly examines the implications that shale gas prospectivity may have to New Zealand sedimentary basins if deemed a viable source of natural gas.

All depths expressed in well sheets and laboratory test samples are measured depths below rotary table (mbrt). This datum takes into account the height above sea level of the semi-submersible rig used during drilling operations. The adopted geological timescale is after Copper (2004) and can be viewed in Appendix A: New Zealand Geological Timescale. 


\subsection{Petroleum Geology Concepts}

\subsection{General Introduction}

Petroleum systems bring together all the elements and processes required for the generation, accumulation and exploitation of hydrocarbon compounds (Magoon \& Dow, 1994). Petroleum is a chemical compound which comprises a complex mixture of hydrocarbons derived from a range of organic material. The material is sought after for the generation of various forms of energy, this resource is recognised as either: 1) biogenic gas; 2) thermogenic gas; 3) gas condensate; 4) natural bitumen; or 5) crude oil. There are two types of hydrocarbon resource identified, these are known as conventional and unconventional systems. These systems exhibit different petroleum generation characteristics but ultimately produce similar hydrocarbon products.

\subsection{Conventional Hydrocarbon Systems}

A conventional hydrocarbon system comprises five key elements necessary for hydrocarbon generation and entrapment; 1) source rock; 2) migration and expulsion; 3) reservoir; 4) seal; and 5) trap. These elements and processes must be correctly arranged in both time and space so that organic matter included in a source rock can be converted into a petroleum accumulation favourable for exploitation (Magoon \& Dow, 1994; Allen \& Allen, 2005).

\section{Source Rock}

This is a rock which has or is capable of generating hydrocarbons. Organic rich in nature, source rocks are formed in oxygen-deficient environments such as deep water marine, lacustrine or deltaic frontiers (Selley, 1998). Terrestrial or marine organic matter deposited in these anoxic conditions is buried, trapping numerous living micro organisms, dead organic material and various minerals (Tissot \& Welte, 1978).

Organic matter is divided into two components; bitumen, which is soluble in organic solvents and kerogen which is an insoluble fraction. Bitumen, which is the smallest fraction, includes indigenous aliphatic, aromatic and N-S-O compounds (i.e. resins and asphaltenes), including migrated hydrocarbons generated from elsewhere (Gluyas \& Swarbrick, 2006). Kerogen, which is the most abundant organic component on the planet, is a term used to describe complex organic compounds (Dow, 1977). This is a mixture of organic materials, rather than a specific form, so no precise chemical formula can be assigned. It has a high molecular weight (> 1000 Daltons) and is insoluble in normal organic solvents. Different organic precursors influence the kerogen type produced; this in turn affects the variety of hydrocarbon generated (Table 2.1). 


\begin{tabular}{l|l} 
Kerogen Type I & $\begin{array}{l}\text { Source rocks formed from algal (lipids) remains or severe biodegradation. They are deposited } \\
\text { under anoxic conditions in deep lakes and laucustrine environments. Exhibiting high initial H/C } \\
\text { and low O/C ratios. This kerogen type is oil and gas prone. }\end{array}$ \\
\hline Kerogen Type II & $\begin{array}{l}\text { Source rocks formed from marine planktonic remains and autochthonous organic matter. They are } \\
\text { deposited in neritic marine environments and are frequently observed in many petroleum systems. } \\
\text { Exhibiting high H/C and low O/C ratios, this kerogen type is oil and gas prone, but has a lower } \\
\text { yield than type I kerogen. }\end{array}$ \\
\hline Kerogen Type III & $\begin{array}{l}\text { Source rocks are formed from terrestrial plant matter that has been decomposed by bacteria and } \\
\text { fungi under oxic or sub-oxic conditions. Exhibiting low H/C and initial high O/C ratios, the oil } \\
\text { potential is decreasing tending to generate mostly gas. }\end{array}$ \\
\hline Kerogen Type IV & $\begin{array}{l}\text { Source rocks formed from terrestrial and marine organic matter. A residue of type III kerogen, it is } \\
\text { highly decomposed organic matter with little to no hydrocarbon potential. }\end{array}$
\end{tabular}

Table 2.1: Kerogen types present in a conventional petroleum system.

A notable difference associated with kerogen type is the hydrocarbon yield with oil prone kerogen forming with initially high $\mathrm{H} / \mathrm{C}$ and low $\mathrm{O} / \mathrm{C}$ ratios. The potential yield decreases markedly with highly decomposed organic matter which has very low $\mathrm{H} / \mathrm{C}$ ratios. Modified after (Tissot \& Welte, 1978).

Upon burial, chemical reactions begin to occur in the source rock which can be divided into three stages of alteration:

1. During increasing burial (depths up to $2000 \mathrm{~m}$ ) organic matter is separated into bitumen and kerogen. With continued increasing burial depths, overburden pressure and elevated temperature causes a progressive rearrangement of the kerogen to occur leading to the formation of a wide variety of hydrocarbon compounds.

2. Catagenesis: When sufficient burial depths (c.a. 2000 to $7000 \mathrm{~m}$ ) and high temperature regimes (c.a. $50^{\circ} \mathrm{C}$ to $160^{\circ} \mathrm{C}$ ) are reached, the main zone of oil generation (the cracking zone) occurs. Carbon-carbon and Ester bonds are broken producing "wet" gas which typically contains less than $85 \%$ methane and more complex hydrocarbons (e.g. >IC4) (Figure 2.1).

3. Metagenesis: The final stage of kerogen degradation which is only reached in sufficiently old or deep sedimentary basins and is a major rearrangement of the aromatic nuclei contained in the remaining kerogen and generates only 'dry' gas. Dry gas contains no or insignificant amounts of liquid hydrocarbons and is over $95 \%$ methane (Hyne, 1991).

A conceptual tool that illustrates the types of hydrocarbon generated is the Van Krevelen diagram (Dow, 1977) (Figure 2.1). The hydrocarbon characteristics generated can be measured by vitrinite reflectance (Ro\%) which is a key method of measuring the temperature history of the basin have reached. During diagenesis typical Ro\% values are $<0.5 \%$; catagenesis $0.5 \%-2.0 \%$; and metagenesis values between $2.0 \%$ $-4.0 \%$ (Magoon \& Dow, 1994). The onset of oil generation correlates with a reflectance value ranging between $0.5 \%-0.6 \%$ and the termination of oil generation with reflectance values in the order of $0.85 \%$ $1.1 \%$ (Figure 2.1). 

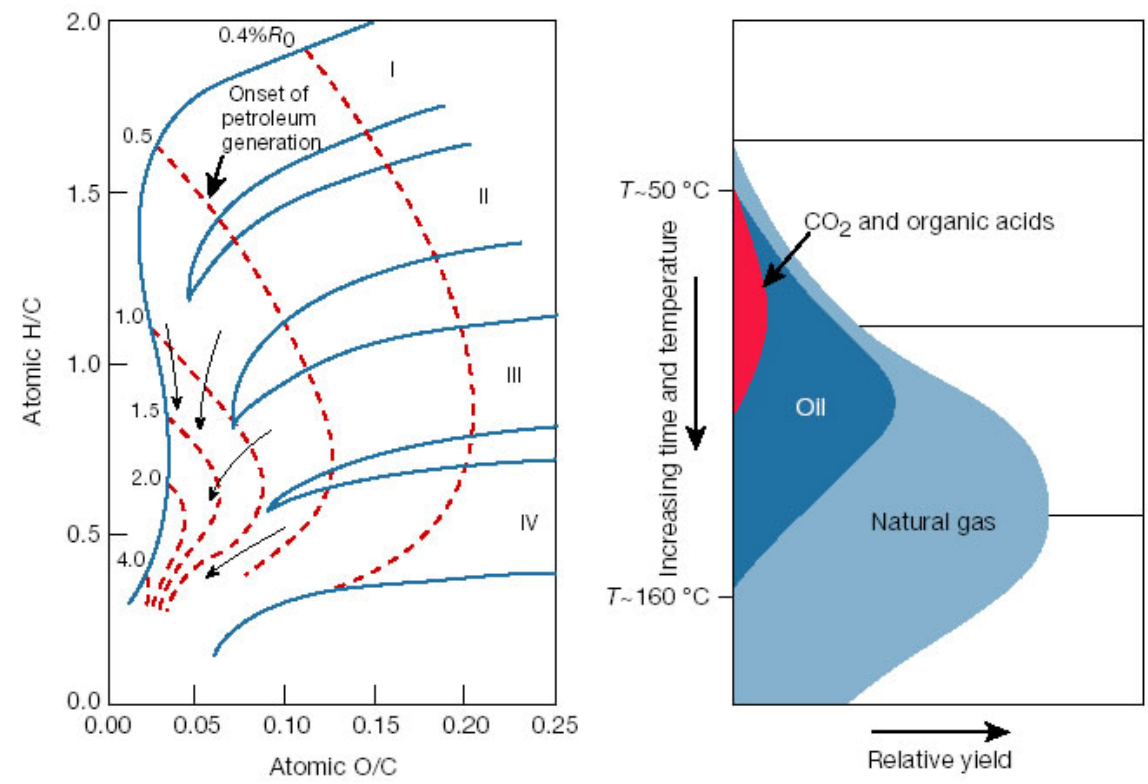

Figure 2.1: Van Krevelen diagram and oil generation window.

Corresponding to Table 2.1; kerogen types are graphically plotted according to their $\mathrm{H} / \mathrm{C}$ and $\mathrm{O} / \mathrm{C}$ ratio. With increasing burial and temperature the onset of oil generation is followed by natural (dry) gas generation. These changes are sequentially occurring with increasing vitrinite reflectance values. Note the oil window is tightly controlled by temperature. After (Gluyas \& Swarbrick, 2006).

\section{Migration \& Expulsion}

The Van Krevelen diagram illustrates physical changes that occur in hydrocarbons, resulting in changes in molecular weight which correspond to increased buoyancy. Increased buoyancy will result in the hydrocarbon attempting to move out of the source rock in a process known as migration. Migration is divided into two stages; primary and secondary migration.

Primary migration is the initial expulsion of hydrocarbon from the fine grained, low permeability source rock into a carrier bed of much greater permeability (Gluyas \& Swarbrick, 2006). This is controlled by three mechanisms; 1) diffusion; 2) oil-phase expulsion; and 3) solution in gas.

1. Diffusion occurs on a minor scale over short distances. It is limited to the edges of thick source units or to thin source beds and is probably most effective in immature rocks, where pre-existing light hydrocarbons bleed out of the rocks prior to the onset of significant generation and expulsion.

2. Oil-phase expulsion occurs when microfracturing, induced by internal pressures are created as hydrocarbon develops. Laminated source rocks may expel hydrocarbon with greater efficiency along planes of weakness such as bedding planes. Once the internal pressure has returned to normal, the microfractures heal, thus isolating the hydrocarbon. Continued generation leads to further overpressuring, repeating the cycle. 
3. The expulsion of oil dissolved in gas requires there to be a separate gas phase. This scenario is expected in source rocks capable of generating gas and in the latter phases of catagenesis and is considered a minor mechanism for oil expulsion.

Distances travelled by migrating hydrocarbon during the primary phase are short. It is difficult and slow because of the low matrix permeability found in source rocks. Secondary migration is controlled by buoyancy forces and concentrates hydrocarbon into specific sites (traps) where it may be commercially extracted (Allen \& Allen, 2005). Hydrocarbon moves through wider pores in carrier beds (e.g. sandstones or carbonates) which are coarse-grained and more permeable than those experienced during primary migration. The distinction between primary and secondary migration is based on pore size and rock type. Hydrocarbon is less dense than surrounding formation water and lithology and therefore more buoyant (Figure 2.2). Capable of displacing water downward, hydrocarbon buoyancy force is proportional to the height of the oil column and the density difference with formation water.

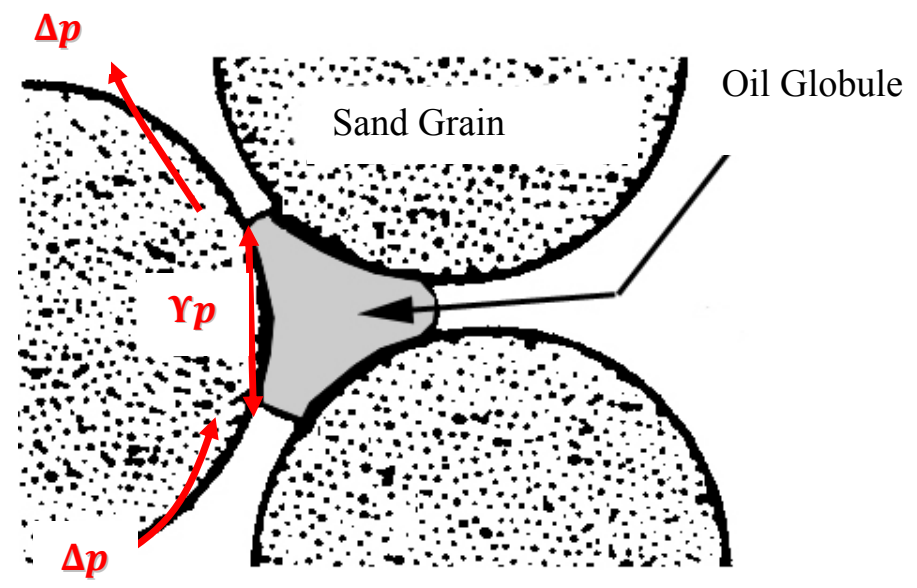

Figure 2.2: Migration of hydrocarbon between clastic sand sized grains.

In order for the oil globule to pass between the pore throats, it must deform in shape. This will only occur when the oil globule pressure is equal or lower to the opposing capillary force. Opposing this buoyancy force $(\Delta \rho)$ is the capillary entry pressure; which is the force resisting the movement of hydrocarbon into the pore throats. Capillary pressure opposes the buoyant force until the radius of curvature inside the distorted hydrocarbon globule is equal at its lower and upper ends. Only then will the hydrocarbon globule pass through the pore throats (Allen \& Allen, 2005).

The globule of oil must deform in order to pass through a narrower throat, which is expressed in Equation 2.1 .

$$
\Delta p=\Upsilon p(\mathrm{P} w-\mathrm{P} p)
$$

Equation 2.1: Secondary migration buoyancy force.

Where, $\Delta p$ is the Buoyancy Force require to enter the pore throat, $\Upsilon p$ is the height of the petroleum column, Pw is the subsurface density of water and $P p$ is the subsurface density of petroleum. After (Allen \& Allen, 2005)

If the buoyancy force is too small or the pore throat diameter too narrow for hydrocarbon to migrate further; accumulation occurs. Secondary migration occurs in a preferential direction that offers the greatest buoyant advantage. This may include; 1) up-dip perpendicular to structural contours; and 2) oblique angles to structural contours when capillary entry pressure exceeds buoyancy forces. 


\section{Reservoir}

A reservoir is a porous or fractured lithology where hydrocarbon undergoing secondary migration can accumulate. Accumulation occurs in an environment where buoyancy pressures of migrating hydrocarbon are in equilibrium with the pore entry pressures (e.g. where buoyancy force is equal to pore throat entry pressure). Essential to reservoir rock quality is porosity and permeability; voids to store the hydrocarbon (porosity) and connectivity (permeability) which allows the hydrocarbon to move. The pore diameters must also be above a minimum size because if the ratio of total pore volume to inner surface area is too low; capillary attraction of the mineral grains and the hydrocarbon will hold the fluids in the rock reducing effective permeability (Tissot \& Welte, 1978).

The primary porosity of a rock is dependent on the packing characteristics and sorting of its component grains. Well sorted sands with spherical grains such as beach or dune sands make excellent reservoirs with high primary porosity. With increasing overburden pressure and associated recrystallisation and cementation, sandstone begins to lose porosity (Pye \& Krinsley, 1985). This is now identified as secondary porosity, where mouldic (dissolution of shell fragments and other particles) pores is created as a result of quartz framework grain dissolution during late diagenesis, leading to possible fracture or fault development.

Hydrocarbon accumulation is typically found in clastic or detrital reservoir rocks such as sandstones and highly siliceous siltstones (Selley, 1998). Reservoir rocks must be sealed by an overlying relatively impermeable cap rock to inhibit the loss of buoyant hydrocarbons.

\section{Seal}

A seal (or cap) rock is a fine grained clastic, shale, evaporite or chalk lithology which impedes hydrocarbon migration (Gluyas \& Swarbrick, 2006). The pore entry pressures must exceed the buoyancy force exerted by the hydrocarbon in the reservoir. The seal must cover a large continuous area in order to be effective. Rocks which vary in lithology, faulted and fractured are prone to leakage and may not effectively seal hydrocarbon reservoirs. 


\section{Trap}

The final requirement of a conventional hydrocarbon system is a trap to capture and hold the hydrocarbon. Traps can be either structural or stratigraphic in nature. Structural traps are formed by a deformation in the rock layer that contains the hydrocarbons. Domes, anticlines, and folds are common structures and fault-related features may also be classified as structural traps if closure is present. Stratigraphic traps are formed when other impermeable rock seals a reservoir or when a permeability difference (facies change) within the reservoir occurs. Stratigraphic traps can form against either younger or older time surfaces. Traps are often a combination of structural and stratigraphic elements and are summarised (Table 2.2).

\begin{tabular}{l|l|l} 
Structural & Tectonic & $\begin{array}{l}\text { Extensional } \\
\text { Compressional }\end{array}$ \\
\hline \multirow{2}{*}{ Diapiric } & $\begin{array}{l}\text { Salt Movement } \\
\text { Mud Movement } \\
\text { Plutonic Movement }\end{array}$ \\
\hline & Compactional & Drape Structures \\
\hline \multirow{2}{*}{ Stratigraphic } & Depositional & $\begin{array}{l}\text { Pinchouts (dune bars, reefs, channels). } \\
\text { Unconformities (erosional subcrop, karst) }\end{array}$ \\
\hline & Diagenetic & $\begin{array}{l}\text { Mineral precipitation } \\
\text { Tar mats } \\
\text { Permafrost } \\
\text { Gas hydrate crystallisation }\end{array}$ \\
\hline
\end{tabular}

Table 2.2: Structural and stratigraphic hydrocarbon traps.

Conventional hydrocarbon exploration in the Canterbury Basin has targeted structural traps of Cretaceous age. Modified after Allen \& Allen, (2005).

An example of a structural trap is the Kapuni gas/condensate field, which is situated onshore Taranaki parallel to the northerly trending Manaia fault system. Transgressive sequences of alternating sandstones, shales and coals are contained within an unbroken anticline structure.

Stratigraphic traps are formed by changes in the characteristics of the rocks themselves; lateral facies (i.e. fining up sequences) and spatial variations create pinch out and unconformable traps where hydrocarbon can accumulate. Shale gas accumulations effectively occur in stratigraphic traps. Low porosity and permeability seal rocks occur over large spatial areas, exhibit subtle folding and show no buoyancy driven accumulation conditions. Stratigraphic pinch outs or natural fractures can occur as conduits for the shale gas; which are then stored as free gas or absorbed onto kerogen or clay particle surfaces (Boyer et al., 2006).

The best known and historically most prospective structural trap is the anticline. Variation of this trapping mechanism is illustrated in Figure 2.3B. Prevalent in New Zealand and particularly the Cretaceous 
reservoirs of the Canterbury Basin, extensional (A and F) fault controlled traps constitute a known hydrocarbon system which is overlain by a sealing lithology usually mudstone.

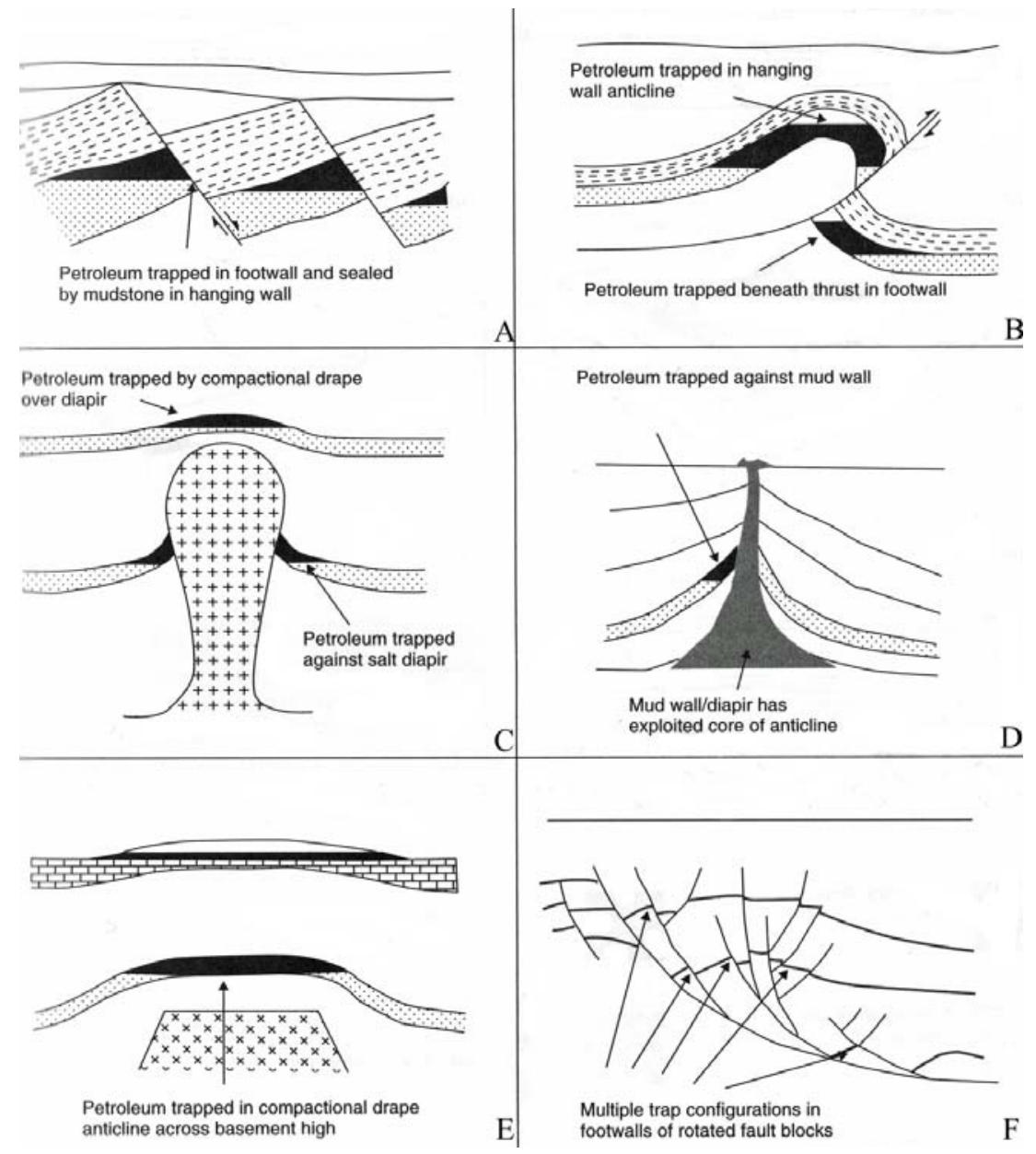

Figure 2.3: Structural trap types.

Image $\mathrm{A}$ has formed in response to extensional faulting allowing migration of hydrocarbon to occur between the foot and hanging wall along separate fault plans. Image B has formed in response to convergent movement rupturing an existing anticlinal trap. Hydrocarbon is trapped between the trust and the footwall by the contiguous seal rock containing the hydrocarbon in the hanging wall. Images $\mathrm{C}$ through $\mathrm{E}$ share similar properties as they have experienced an upwelling of less dense plutonics, mud or salt in the form of a diaper or melt which has displaced and separated overlying hydrocarbon accumulation. This can lead to over-pressuring of the reservoir and leakage, particularly in image $D$ where the mudstone integrity may be compromised by chemical and mechanic alteration. Image $F$ illustrates a large scale multi-trapping mechanism associated with extensional tectonics where multiple trap configurations give rise to migration paths and fault bound traps. Modified after Gluyas \& Swarbrick, (2006). 


\subsection{Unconventional Hydrocarbon Systems}

Unconventional oil and gas resources can be characterised by either rock with very low permeability or intractable fluids where some form of stimulation is required for commercial production (Johnson \& Dore, 2009) (Figure 2.4). Exploration and production paradigms which have been applied to conventional hydrocarbon resources may not apply in unconventional systems. Unconventional gas for instance, can be sourced from synclines rather than anticlines, in other cases water is encountered up dip of accumulating gas. Conventional gas resources are buoyancy driven which form discrete accumulations in structural or stratigraphic traps. Unconventional hydrocarbon, does not share these characteristics, but is instead regionally pervasive in nature (Law \& Curtis, 2002). Technologically complex to exploit despite being ubiquitous relative to conventional oil and gas deposits, the unconventional hydrocarbon recovery factor is commonly low (Schmoker, 2002). Unconventional hydrocarbon systems can yield; 1) heavy crude; 2) coal bed methane; 3) tar sands; 4) tight gas; and 5) shale gas or Basin Centred Gas System (BCGS explained in Section 2.3.2). For the purpose of this study, shale gas systems and BCGS are considered further in regard to the Canterbury Basin.

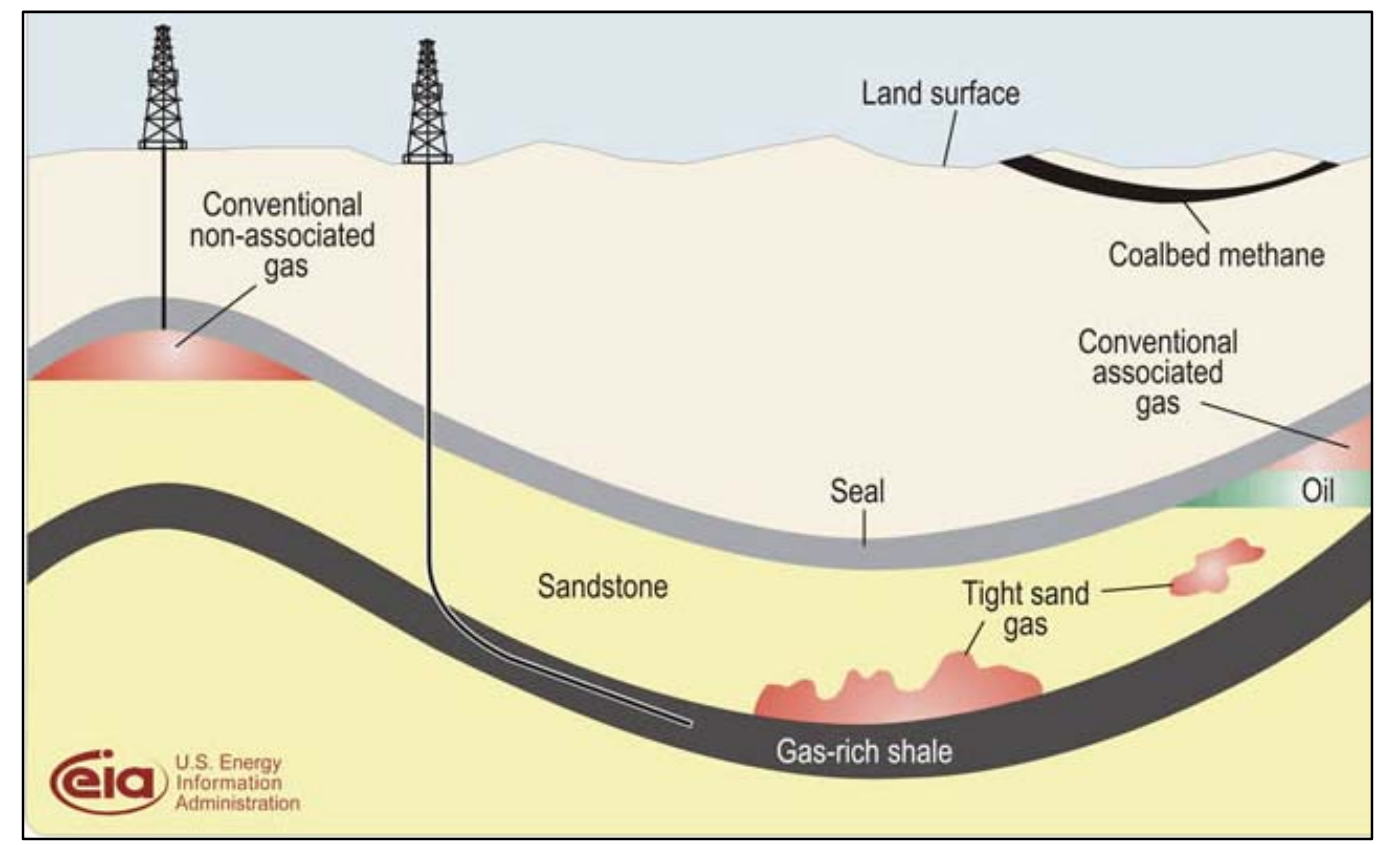

Figure 2.4: Schematic hydrocarbon systems.

Tight sand gas and gas-rich shale comprise the unconventional element of this diagram. Note the factors controlling accumulation, not buoyancy dependant as expected in the conventional sense. Instead unconventional hydrocarbon is laterally pervasive irrespective of structure. After the (US Information Administration, 2010). 


\subsubsection{Shale Gas}

Located in very fine grained sedimentary rocks, shale gas is characterised by subtle stratigraphic trapping mechanisms (e.g. pinchouts), ultra low porosity and permeability, gas saturated, variable total organic content, seals of variable lithology, and relatively short migration distances (Gluyas \& Swarbrick, 2006). In effect, the shale can act as source, seal and the reservoir for the natural gas. Shale gas systems are further defined by separating gas accumulations into either biogenic or thermogenic sources, although mixtures of the two gas types can occur (Jarvie et al., 2007).

1. Biogenic gas is formed at shallow depths and low temperatures by anaerobic bacterial decomposition of sedimentary organic matter.

2. Thermogenic gas is formed at deeper depths by:

a) Thermal cracking of sedimentary organic matter into hydrocarbon liquids and gas (this gas is co-genetic with oil, and is called "primary" thermogenic gas).

b) Thermal cracking of oil at high temperatures into gas ("secondary" thermogenic gas) and pyrobitumen.

Biogenic gas is very dry (i.e., it consists almost entirely of methane). In contrast, thermogenic gas can be dry, or can contain significant concentrations of "wet gas" components (ethane, propane, butanes) and condensate (C5+ hydrocarbons). Typically occurring in intervals where porosity and permeability values are lower than $13 \%$ and $0.1 \mathrm{md}$ respectively, shale gas can accumulate in three ways (Selley, 1998);

1. Adsorbed gas, which is controlled by the amount of organic matter present.

2. Free gas, which is not physically adhered onto internal surfaces.

3. Soluble gas, which is stored within water and/or bitumen.

According to Bowker, (2007) and Johnson \& Dore, (2009) shale gas systems can also vary considerably in their physical and chemical state and therefore no single means of measuring their productivity is known. Figure 2.5 illustrates several elements required for shale gas productivity, but makes no division between any one particular constituent. 
Three co-dependent relationships however, can be conceptualised from this model that culminate in;

1. Thickness $\rightarrow$ organic richness $\rightarrow$ maturation $\rightarrow$ gas in place.

2. Mineralogy $\rightarrow$ brittleness.

3. Pore pressure $\rightarrow$ permeability.

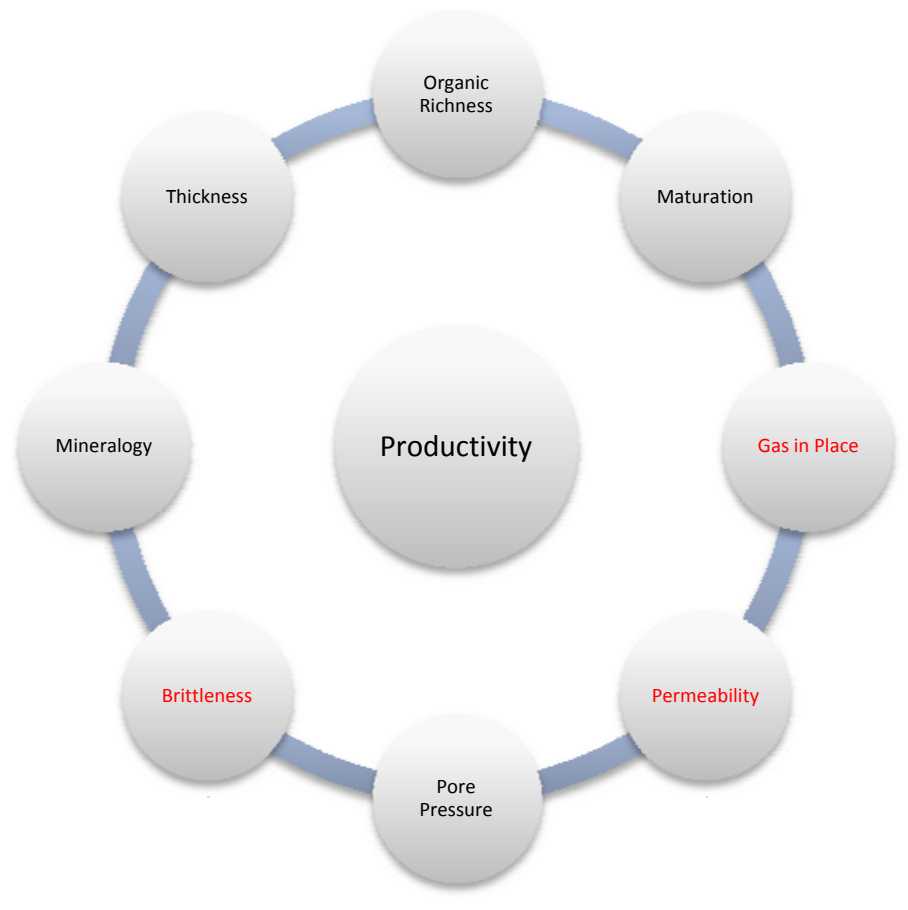

Figure 2.5: Elements of a shale gas play.

The thickness of organic rich shale can vary; for instance, the Barnett Shale, Fort Worth, Texas is up to c.a. $230 \mathrm{~m}$ thick, whereas the Tartan Formation averages c.a. $17 \mathrm{~m}$ thick. Both formations exhibit average TOC values above $3.6 \%$ while maturity $\mathrm{R}_{\mathrm{o}}$ values for the Barnett Shale range between $1.0-1.3 \%$ and the Tartan Formation exhibits a lesser $0.32-0.37 \%$ (Bowker, 2007; Schiøler, et al., 2010). Mineralogy is known to have a major influence on total gas capacity (Ross \& Bustin, 2008). Mudstone which exhibits elevated quartz or carbonate is favourable for shale gas productivity. Relative differences in rock brittleness tend to cluster natural fractures in zones of brittle organic and siliceous-rich facies (Boyer et al., 2006; Gale et al., 2007; and Alpin \& Macquaker, 2010). However, an inverse relation between silica and porosity in some regions (such as in the Western Canada Sedimentary Basin) implies that quartz rich facies do not lead to fracture completion and may not provide optimal gas capacity. The third and final key to shale gas productivity is pore pressure and permeability, whereby abnormally pressured source rock can affect ultimate permeability.

\subsubsection{Basin Centered Gas Systems}

A BCGS as defined by Law (2002) satisfies five main conditions, which exhibit relatively strict criterion than the definition of a shale gas system. This includes; 1) low permeability (between 0.1 and $0.0001 \mathrm{md}$ ); 
2) abnormal pressure (high or low); 3) gas saturation; 4) no down dip water contact; and 5) regionally pervasive accumulations. These gaseous accumulations can only form within closed petroleum systems (e.g. trapped) where highly generative source rocks and primary migration are critical. Two types of BCGS are distinguished on the basis of source rock quality:

1. An indirect system, which is derived from oil-prone source rocks.

2. A direct system, which is typically charged by gas-prone source rocks.

Indirect systems exhibit longer migration pathways than a direct system. Shorter migration distances are indicators of localised near-to-source hydrocarbon charge where the shale rock can be both source and seal. Stratigraphic trapping such as an erosional pinchout structure will exhibit variable seal quality opposed to an indirect system where a good bedding parallel seal quality is usually observed (Table 2.3).

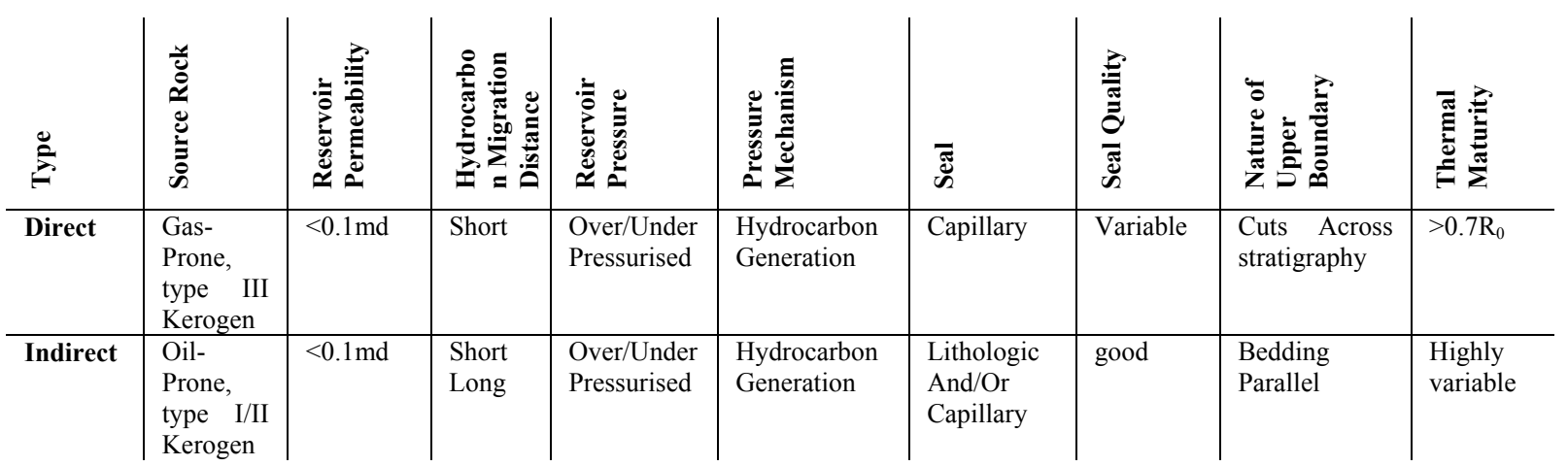

Table 2.3: Direct and Indirect Basin Centred Gas System attributes.

An indirect system seal quality is better than a direct system where variations in stratigraphic trapping mechanisms (i.e. lateral facies change) are greater, causing a more inconsistent seal quality. After Law (2002).

In a similar way to conventional hydrocarbon evolution (e.g. diagenesis, catagenesis, and metagenesis) a BCGS undergoes several phases of hydrocarbon development; a function of geologic process and responses (Table 2.4). 


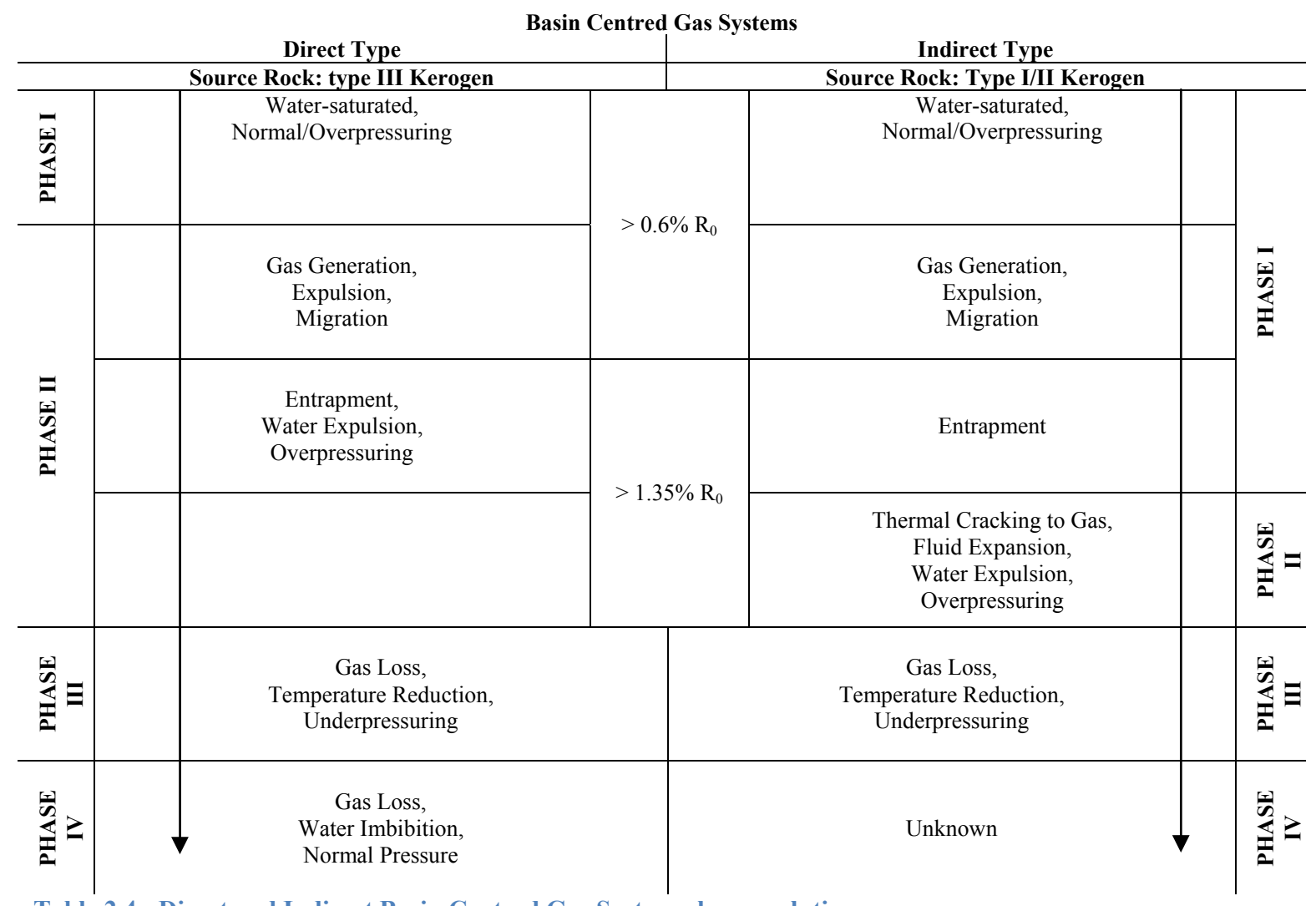

Table 2.4: Direct and Indirect Basin Centred Gas System phase evolution.

After Law (2002).

BCGS are divided into four development phases which correspond to direct and indirect source rock evolution for gas accumulations in low permeability reservoirs:

1. Phase one burial and thermal histories in direct and indirect systems are normally pressured and water saturated. In direct systems, phase one terminates as thermal gas generation commences. This differs slightly from an indirect system where the initiation of thermal cracking from oil to gas is just beginning. Reservoir quality in direct systems is thought to be poor relative to the reservoir quality in an indirect system.

2. During phase two development the type of kerogen distinguishes the direct and indirect systems.

a) In the direct system, source and reservoir rocks undergo further burial and temperature increase to the point where gas is generated. The source rocks begin to generate gas as further burial and temperature increases. Generated gas begins to enter adjacent water-wet relatively porous sandstone or mudstone laminations, eventually accumulating throughout the coarser grained pore systems. The capillary pressure of the water-wet pores is exceeded and free-water is expelled from the pore system, which results in the development of an abnormally pressured (high or low) gas saturated reservoir with no downdip contact.

b) In an indirect system, reservoir quality is assumed to be better quality than that of a direct system despite a similar development track being followed. Expelled oil and gas accumulates 
in structural and stratigraphic traps as discrete, buoyant accumulations with downdip water contacts. In principle, indirect systems follow more closely to a conventional hydrocarbon system where increasing burial and temperature increases lead to accumulated oil cracking to gas which is accompanied by significant fluid volume and pressure increases. Similar to the direct system, the capillary pressure of the water-wet pore system is exceeded replacing free water to form a gas saturated reservoir. Essential to this indirect phase is an effective lithologic top seal in reservoirs formally occupied by discrete oil accumulations.

3. Phase three represents a point where indirect and direct systems are identical. This occurs when both systems evolve into underpressured conditions, which is associated with gas loss and ambient temperature reduction of the basin. Mechanisms controlling this may include regional uplift and erosional unloading and/or heat flow perturbations (Law, 2002). Consequently, relative permeability deficiencies in seal rocks occur allowing gas to escape through leaky seals (e.g. gas chimneys). This loss of gas in conjunction with reduced temperatures results in an underpressured reservoir.

4. The final phase (four) is theoretical but is more applicable to direct systems than indirect systems. Phase four effectively represents the closure of the pressure cycle where continued gas leaks from the direct system seal rocks is accompanied by free water slowly re-entering the underpressured gas bearing reservoirs.

\subsubsection{Hydraulic Fracturing}

In some cases, where formation properties are not conducive to natural fracturing (i.e. ductile rocks or massive mudrock units), the technique of hydraulic fracturing (known as fraccing) is used to increase or restore the rate at which fluids, such as oil, gas, or water can be produced from a reservoir, including unconventional reservoirs such as shale or coal beds (Gale et al., 2007; Griffin, 2009).

Hydraulic fracturing is a technique used to create fractures that extend from the well bore into rock or coal formations. These fractures allow the oil or gas to travel more easily from the rock pores, where the oil or gas is trapped, to the production well. Typically, in order to create fractures a mixture of water, proppants (sand or ceramic beads) and chemicals (which include; methanol, guar gum and ammonium chloride) is pumped into the rock or coal formation.

Eventually, the formation will not be able to absorb the fluid as quickly as it is being injected. At this point, the pressure created causes the formation to crack or fracture. The fractures are held open by the proppants, and the oil or gas is then able to flow through the fractures to the well. Alternatively, acidizing involves pumping acid (usually hydrochloric acid), into the formation. The acid dissolves some of the rock 
material so that the rock pores open and fluid flows more quickly into the well. Fraccing and acidizing are sometimes performed simultaneously, in an acid fracture treatment.

These processes are crucial in low permeability rock as it exposes more of the formation to the well bore and greater volumes of gas can be produced by the increased surface area. The fracture provides a conductive path connecting a larger area of the reservoir to the well, thereby increasing the area from which natural gas and liquids can be recovered from the targeted formation. 


\subsection{Geological Setting of the Canterbury Basin \& Clipper Sub-Basin}

\subsection{Background Tectonic Development}

Basement rocks exposed throughout New Zealand are petrographically similar to those found in Australia and Antarctica (Graham, 2008). During the Mesozoic, New Zealand was part of the Gondwana super continent (Campbell \& Hutching, 2007). Zealandia began forming in response to enormous thicknesses of sediment accumulating east of Gondwana in what is known as the New Zealand Geosyncline. During the Rangitata depositional period (142 - 99 Ma), two distinct groups of rock were deposited; 1) the Murihiku super group (terrane) to the west; and 2) the Torlesse super group (terrane) to the east. Illustrated in Figure 3.1, the Western Province mainly comprises granite and gneiss and the Eastern province greywacke and schist (Dickinson, 1971; MacKinnon, 1983; Campbell \& Hutching, 2007; and Graham, 2008). Predominantly igneous in nature, the Western Province contains four large regional bodies of coarse grained crystalline rock, these being; 1) Hohonu; 2) Karamea; 3) Median; and 4) Paparoa batholiths. The Eastern Province contains sedimentary basement and comprises eight terranes referred to as the: 1) Buller; 2) Takaka; 3) Torlesse Composite (Rakaia and Pahau); 4) Brook Street; 5) Caples; 6) Matai; 7) Murihiku; and 8) the Waipapa composite terrane (Graham, 2008). Additional metamorphic terranes which have been intensely deformed are also recognised in the eastern province record, these being; 1) the Esk Head Melange; and 2) the Whakatane Melange.

After this phase of accretion, sediments of the New Zealand Geosyncline were compressed and folded during the Rangitata Orogeny 142 - 99 Ma. Seafloor sediments were effectively scraped off the subducting plate and folded in stages, causing intense deformation. The western rocks occur as open simple folds, whereas the eastern block was much more severely deformed, commonly in a stack of folds with complex faulting. Concurrent to this process, plutonic rocks were also contributing to the growth of the Zealandia continent as granitic bodies of magma rose and crystallised in the crust.

Sea floor spreading associated with extensional fault movement during the Cretaceous (95-90Ma) along what is now known as the Antarctic Australian Ridge occurred. This separated the two continental land masses of Australia and Zealandia away from the West and East Antarctic landmasses. By the late Cretaceous (65 Ma) Zealandia began to separate in a present day easterly direction away from the Australian landmass creating the Tasman Sea. This continued until the Eocene period (53 Ma).

Following a period of tectonic quiescence renewed seafloor spreading occurred to the southwest of present day New Zealand. Simultaneous strain in the southwest Pacific, associated with the spreading ridge between Antarctica and Australia, created various fault movements which led to the development of the Southern Alps and to the initiation of a new plate boundary across Zealandia (Figure 3.1). The Hikurangi Trough and the Puysegur Trench represent two opposing subduction margins associated with this plate boundary development. The Hikurangi Trough to the east of the present day Wairapapa coast encloses the 
North Island and the western South Island to the Australian plate. The Puysegur Trench which is south west of present day Fiordland encloses the remaining South Island upon the Pacific plate.

Subduction of the present day subduction system is creating rifting in the central North Island through the Taupo Volcanic Zone (TVZ), manifest with a range of basic to rhyolitic volcanic centres and cones (e.g. Mt Tarawera, Taupo Caldera, Mt Tongariro and Ruapehu). Further west, deep-seated subduction has produced the Taranaki Volcanics near New Plymouth. The East Coast of New Zealand continues to receive extensive sedimentary accumulations through continued uplift of the axial ranges and subsequent erosion. A thorough geological evolution is discussed in Section 3. 


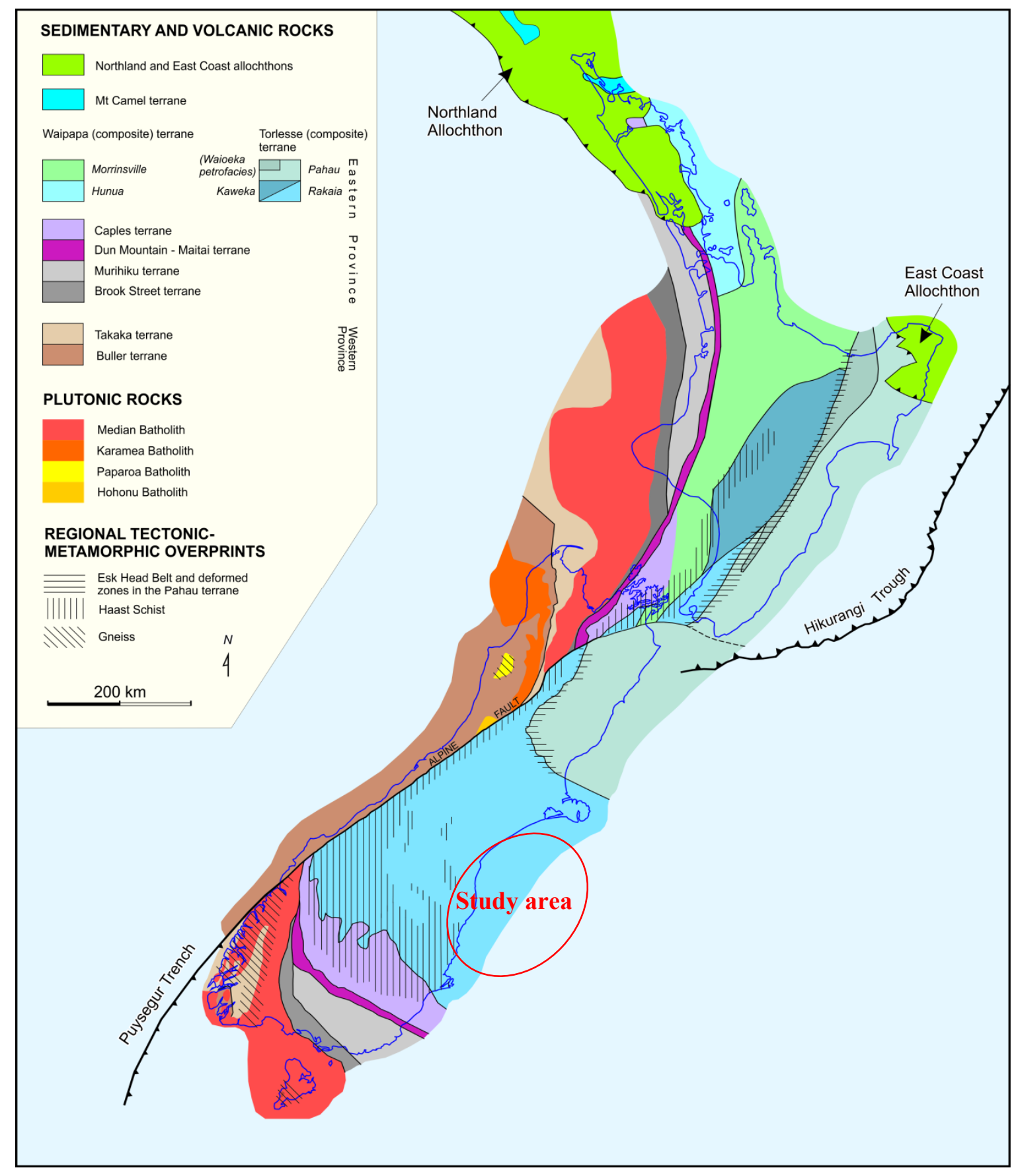

Figure 3.1: New Zealand: Map of tectonostratigraphic terranes.

The sediment input into the study area is derived from the Haast Schist and Torlesse Super Group from the Eastern Province terranes. The study area and much of the South Island east of the Puysegur Trench rest upon the Pacific Plate, the remainder of New Zealand is set upon the Australian Plate. Modified after Graham, (2008).

\subsection{General Introduction}

Hydrocarbon plays are located throughout the Canterbury Basin in mid Cretaceous to mid Paleogene sediments (Killops et al., 1997). The Clipper Sub-Basin (Figure 1.1) is a proven offshore hydrocarbon system, exhibiting all the five elements required for an operating petroleum system (Wilson, 1985; Field \& Browne, 1989). 
A simplified chronostratigraphic model for the area was developed by New Zealand Oil and Gas (NZOG). This model utilises contemporary biostratigraphic and seismic work to date (2010) and has been adopted in this research (Figure 3.2). 

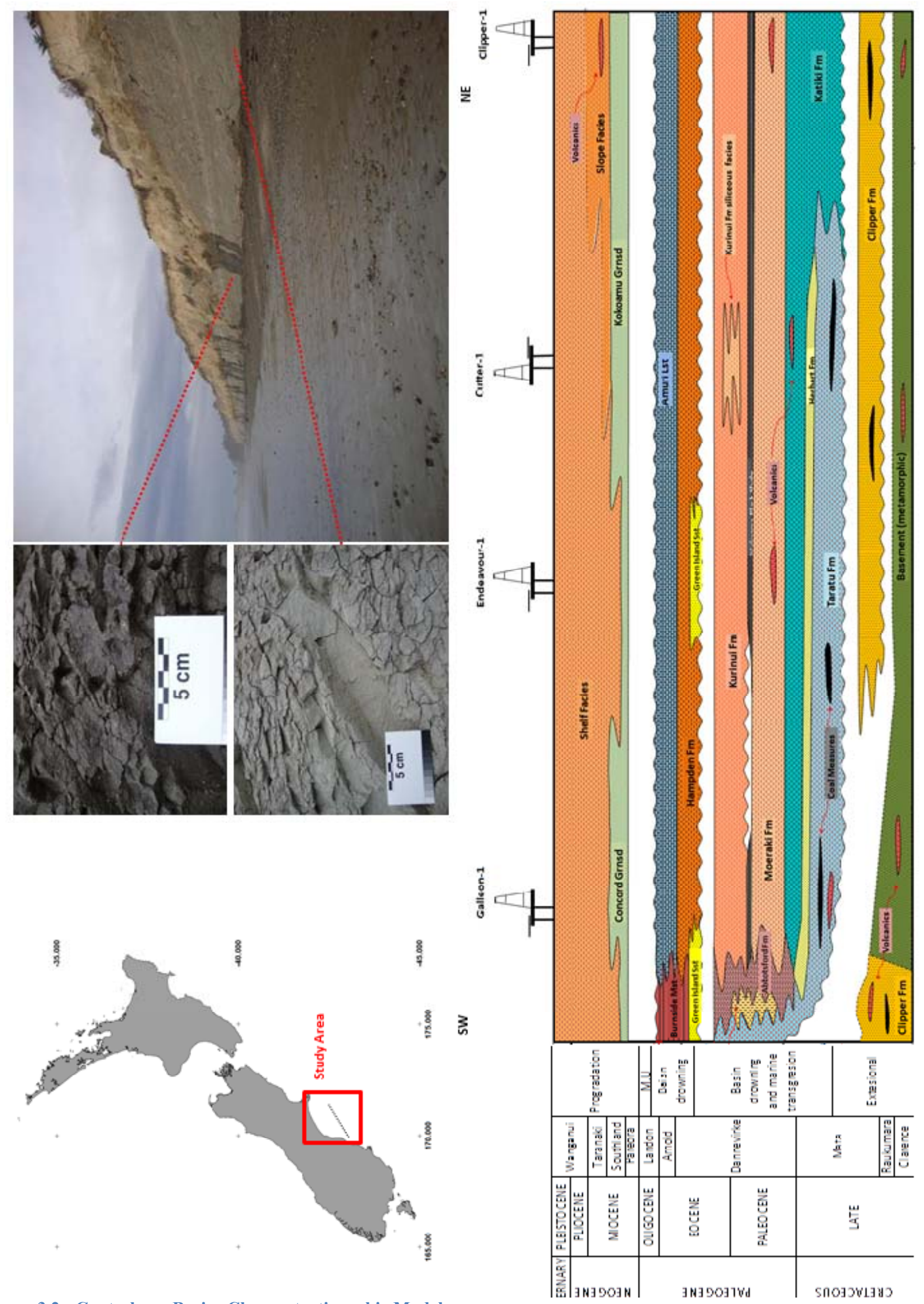

Figure 3.2: Canterbury Basin: Chronostratigraphic Model.

Mid Cretaceous to present day schematic geology of the Canterbury Basin. Twenty formations and lithology types are recognised Modified after personal communication between New Zealand Oil and Gas - author of this study. Inserted photographs refer to Hampden Beach and clearly illustrate the weathered and highly fractured mudrock lithology. 


\subsection{Canterbury Basin: Permian to Cretaceous}

Up to eight tectonostratigraphic terranes have been documented in the South Island (Figure 3.1); the Torlesse Terrane and its metamorphic equivalent, the Haast or Otago Schist are the basement rocks for much of the Canterbury Basin. Together, these terranes have provided the bulk of the sediment into the Canterbury Basin. Three main units make up the Torlesse Terrane:

1. The Torlesse Super Group (terrane) which comprises alternating sandstone and argillite, locally referred to as greywacke are derived from submarine fans and deltaic systems (MacKinnon, 1983). The rocks are divided chronologically into three groups based on age; 1) older Torlesse; Permian to late Triassic age; 2) younger Torlesse; late Triassic to early Cretaceous age; and 3) Esk Head Melange (late Triassic to early Jurassic age).

2. The Haast Schist which comprises of metamorphosed alternating sandstone and mudstone rocks, derived from Torlesse rocks. The schist is predominantly of chlorite grade becoming biotite schist closer to the Alpine Fault. An early Jurassic to mid Cretaceous age $(200-90 \mathrm{Ma})$ is assigned (Bishop et al., 1985). It grades northward into the quartzo-feldspathic Torlesse Supergroup.

3. A derivative of the Torlesse super group is the Esk Head Melange and Waipapa terrane which comprises early to late Jurassic alternating sandstone and argillite. This formed as a product of avalanching, gravity slumping or sliding associated with the Rangitata Orogeny.

Torlesse sediments that underwent rapid subsidence and formed rift basins during the mid to late Cretaceous were metamorphosed during the Rangitata Orogeny. The dominant faulting pattern in the Canterbury Basin at this time is normal with high-angle faults bounding northeast - southwest trending horst and graben features. Such features are common throughout much of the South Island namely Fiordland, the West Coast, North West Nelson and Marlborough (e.g. Bishop et al., 1985; Laird, 1993; Adams et al., 1998; Sutherland, 1999; Sutherland et al., 2002 and Balfour, 2005).

In the Canterbury Basin, two main depositional centres developed in response to the mid Cretaceous rifting; 1) the Clipper Sub-Basin in the southern Canterbury Basin; and 2) the Central trough in the Great South Basin. Other smaller rift basins also developed during this phase in Canterbury and North Otago (e.g. the Kyeburn Formation at central and north Otago and mid Canterbury respectively, and Trotters Gorge at the Hewson depocentre).

The Clipper Sub-Basin began to infill with coarse grained clastic sediments during the Clarence Series (108.4-95.2 Ma). Sediments include sandstones, mudstones and conglomerates sourced from the widespread, low lying, subaerial exposed Torlesse Supergroup and the Haast/Otago Schist; a mixture of quartzo-feldspathic greywacke and schistose chlorite - rich sediments (Figure 3.3). 
At the same time greywacke and conglomerates were being deposited to the west and are now exposed at Trotters Gorge and Kyeburn containing schist, tuffaceous and ignimbrite sediments Bishop et al.,(1985); Field \& Browne, (1989). This occurred during the lower Clarence Series (Urutawan) and is post-dated by emerging activity in the north of the basin where alkaline volcanism was occurring in Marlborough and at the Mandamus River during the late Clarence Series (Ngaterian). During the deposition of Ruakumara Series (Mangaotanean) the Mt Somers volcanics were erupted from several centres around mid Canterbury and possibly towards the southeast of the basin. This volcanic group ranges from rhyolite through dacite and andesite to high-alumina basalt (Field \& Browne, 1989).

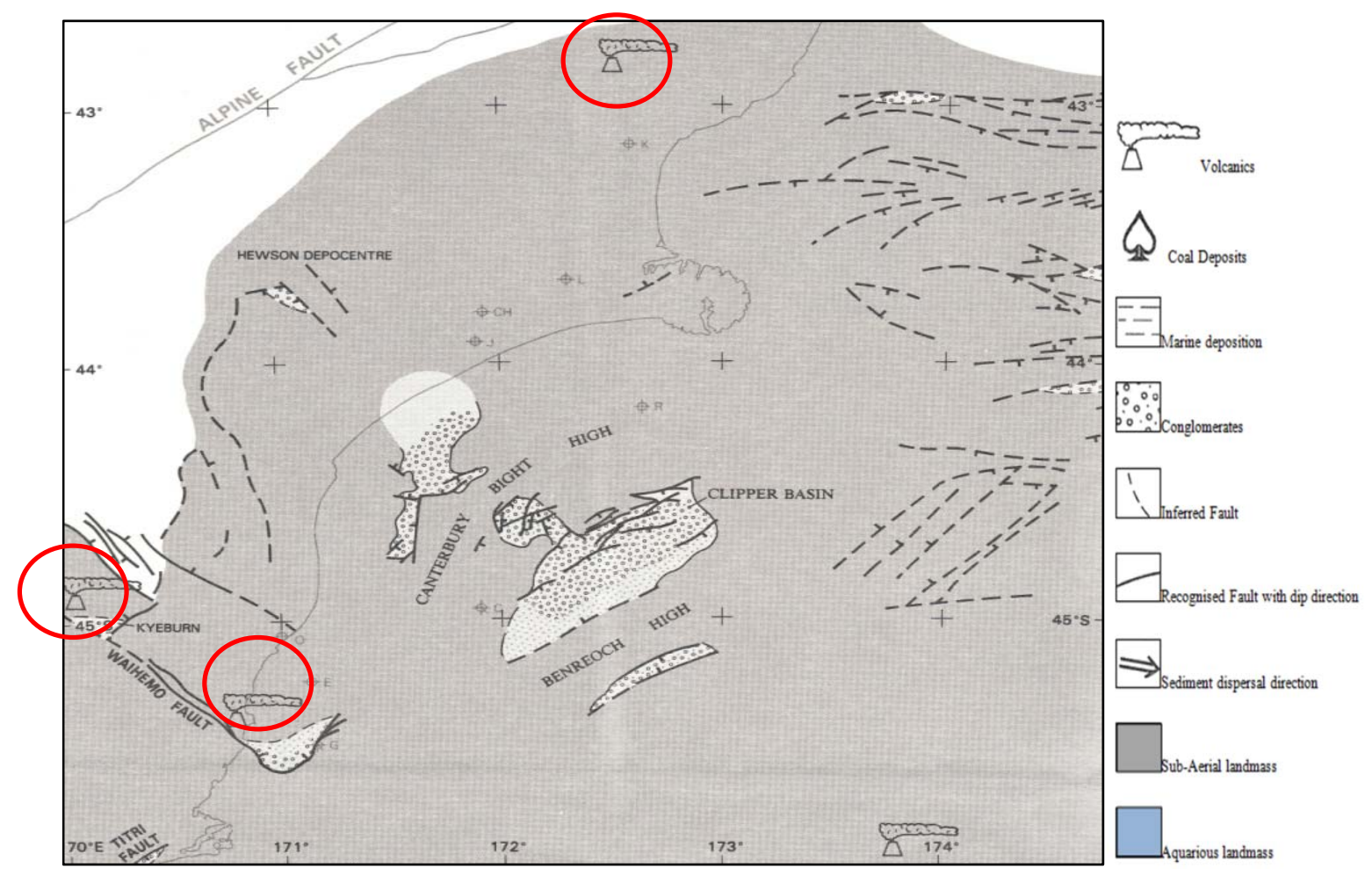

Figure 3.3: Canterbury Basin: Lower Clarence Series paleogeography.

Subaerial erosion or non-deposition characterised the sedimentation during the lower Clarence Series (Albian) causing the Clipper Sub-Basin to infill with coarse clastic sediments. Circled in red, the Kyeburn depocentre, the Mandamus igneous complex and Mt Somers volcanic group erupted throughout the basin during the mid to late Cretaceous, terminating before the Clipper Sub-Basin began flooding by the end of the Ruakumara Series. Modified after Field and Browne (1989). 
The upper Ruakumara Series marks a time when the Clipper Sub-Basin rapidly subsided (Figure 3.4). This is likely to have commenced in the first instance from the east and northeast concurrent with continued peneplanation and localised deposition of fine grained terrestrial sediments in the west of the Canterbury Basin.

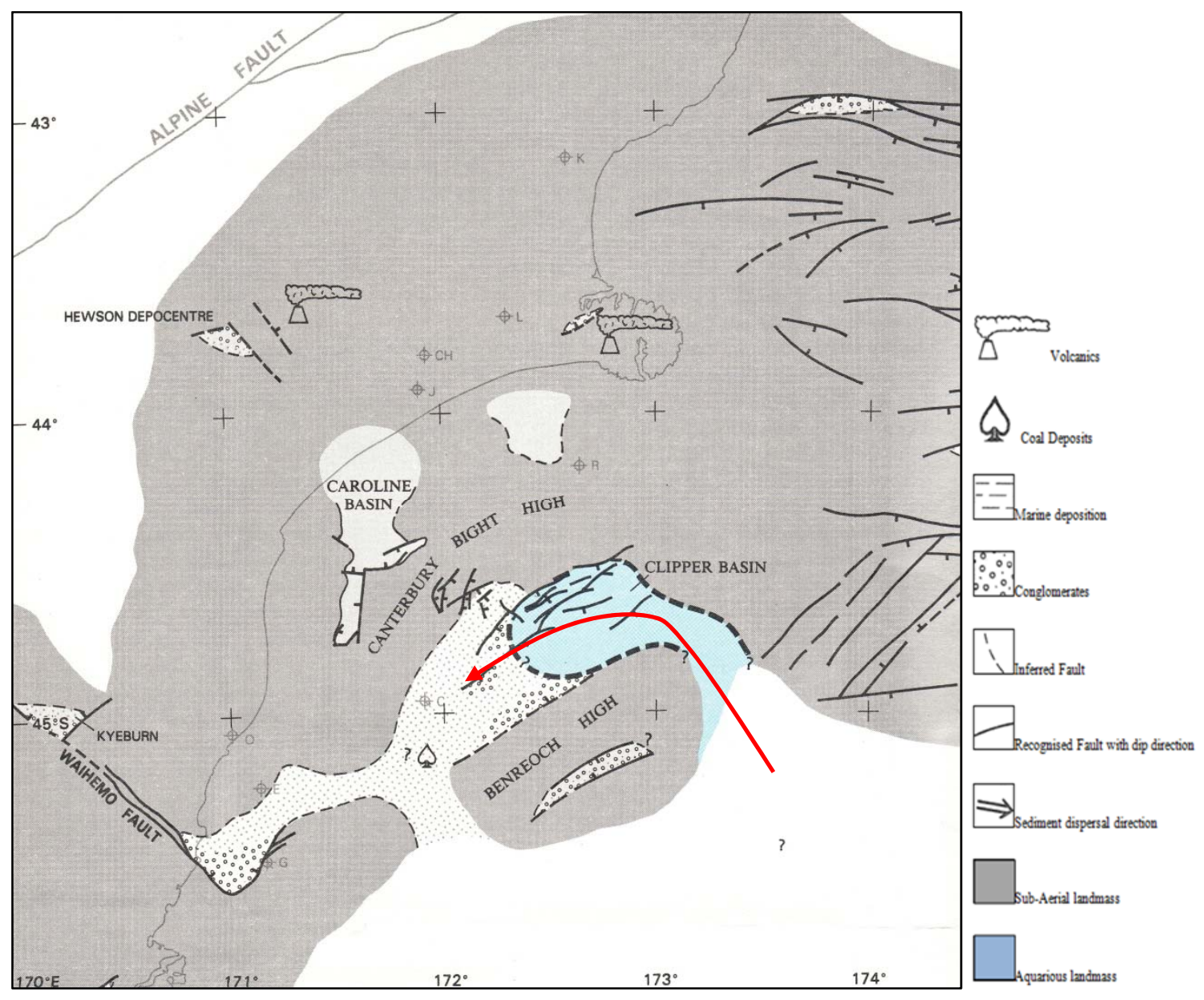

Figure 3.4: Canterbury Basin: Lower Ruakumara Series paleogeography.

The sea entered from the east and northeast (red arrow) in the Clipper Sub-Basin. This is the first instance marine transgressive sediments began overlying the coarse grained clastics in the Clipper Sub-Basin. The Kyeburn depocentre, the Mandamus igneous complex and Mt Somers volcanic group which erupted further south in the basin during the mid to late Cretaceous, terminating before the Clipper Sub-Basin began flooding by the end of the Ruakumara Series. During this time, the Caroline Basin begins to infill subaerial erosion of the Canterbury Bight High. Modified after Field and Browne (1989).

The oldest sediments to overlie economic basement in the Canterbury basin are clastic sediments of the Clipper Formation; a mid to late Cretaceous (Ngaterian to Teratan) sandstone package. According to Killops et al., (1997), oil and gas shows observed and tested in the Clipper-1 and Galleon-1 wells is likely to have originated from the coal measures of the upper Clipper Formation (Figure 3.4).

Isopach map interpretation of the Clipper Sub-Basin indicate mid to late Cretaceous sediment thickness is in excess of three kilometres (Figure 3.5). Active faulting is predominant at the north western margin of the infilled graben feature. 


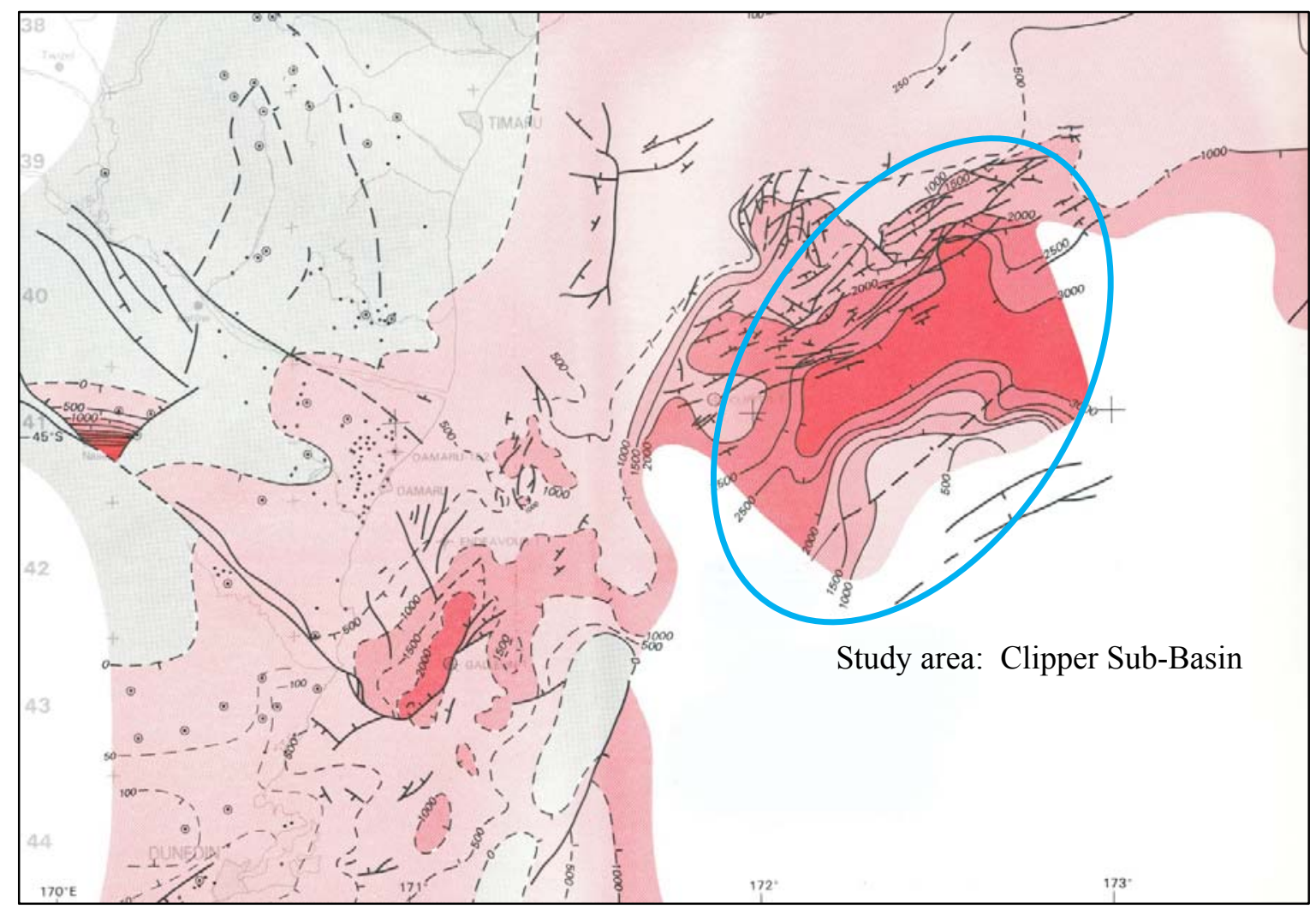

Figure 3.5: Canterbury Basin: Mid to late Cretaceous isopach map.

Circled in blue is the Clipper Sub-Basin which exhibits mid to late Cretaceous thicknesses in excess of three kilometres. This is the deepest and thickest sediment package which formed in response to infilling of Cretaceous NE - SW trending graben features. Dark red denotes basal depths over $3 \mathrm{~km}$, whereas pink denotes depths between surface and $500 \mathrm{~m}$. After Field and Browne (1989).

\subsection{Canterbury Basin: Paleogene}

Faulting during the late Cretaceous was followed by a period of relative tectonic quiescence in the Paleogene with only localised fault movements, typically reactivations of Cretaceous faults (Field \& Browne, 1989). Basin subsidence continued into the Paleogene with sediments derived from a low lying landmass to the west of the basin and from the subaerially exposed Chatham Rise to the north east (Wood et al., 1989). This transgression resulted in the deposition of the Mata and Dannevirke Series, representing the first marine sediments identified in the Clipper Sub-Basin. The Katiki (Haumurian - Teurian) and Moeraki (Teurian) Formations were deposited south and west of the Canterbury Bight during this phase (Figure 3.7).

Basaltic volcanism was also pronounced during the Paleocene throughout central Canterbury which mainly occurred in two areas of the basin. The first volcanic complex is known as the Endeavour volcanics which erupted in the south of the basin during the late Teurian to Waipawan. This subalkaline theoleiitic volcanism continued in central Canterbury erupting the View Hill volcanic group which culminated in the Waipawan.

During early Eocene time, paleocirculation became restricted to the north, placing the Canterbury Bight under a marginally nertic water mass (Morgans, 2009). By late Eocene time, faulting and renewed 
movement of extensional faults saw the depo-centre begin to develop around the Farlie area (Figure 3.11). According to Field and Browne (1989) these movements may have been precursors to the convergence of the Alpine Fault boundary. This transform plate boundary divided the developing Hikurangi margin in the north east and the already established Puysegur margin in the south west.

Increased plate convergence produced localised faulting and differential subsidence which led to the development of the Endeavour High (Figure 1.1). This NE-SW trending sub-aerial or shallow sub-marine region of late Eocene - early Miocene age bounded the Clipper Sub-Basin to the northwest. Increased carbonate facies observed in the late Eocene to Oligocene was likely a result of restricted clastic sedimentation across much of the Canterbury Basin which covered the region in limestone (Amuri Limestone).

The late Oligocene was characterised by alkalic to tholeitic volcanism resulting in the emplacement of the Brothers Basalt and Cookson Volcanics (Field \& Browne, 1989). But, most notable in the mid Oligocene sediment record, is what is now known as the Marshall Unconformity. Fulthorpe et al., (1996) dated the unconformity as between 34.6 and $29 \mathrm{Ma}$ (Whaingaoan - Duntroonian). This represents a break in sedimentation of at least 3 million years and occurred widely throughout shelf sequences in the eastern New Zealand passive continental margin. Possible causes for the unconformity and its associated glauconitic and bioclastic sediments are sea-level fluctuations (Lever, 2007), including those related to local geoidal effects, or erosive bottom waters stemming from the development of Antarctic glaciations or from splitting of the southern continents (Carter, 1985).

\subsubsection{Clipper Sub-Basin Dannevirke Series Formations}

The Dannevirke Series (65-43 Ma) forms a major part of the Paleogene period (65-23.8 Ma). In the Canterbury Basin, six formations occur within the Dannevirke Series. These formations are summarised in Figure 3.6 and Table 3.1 and explained in greater detail thereafter. 


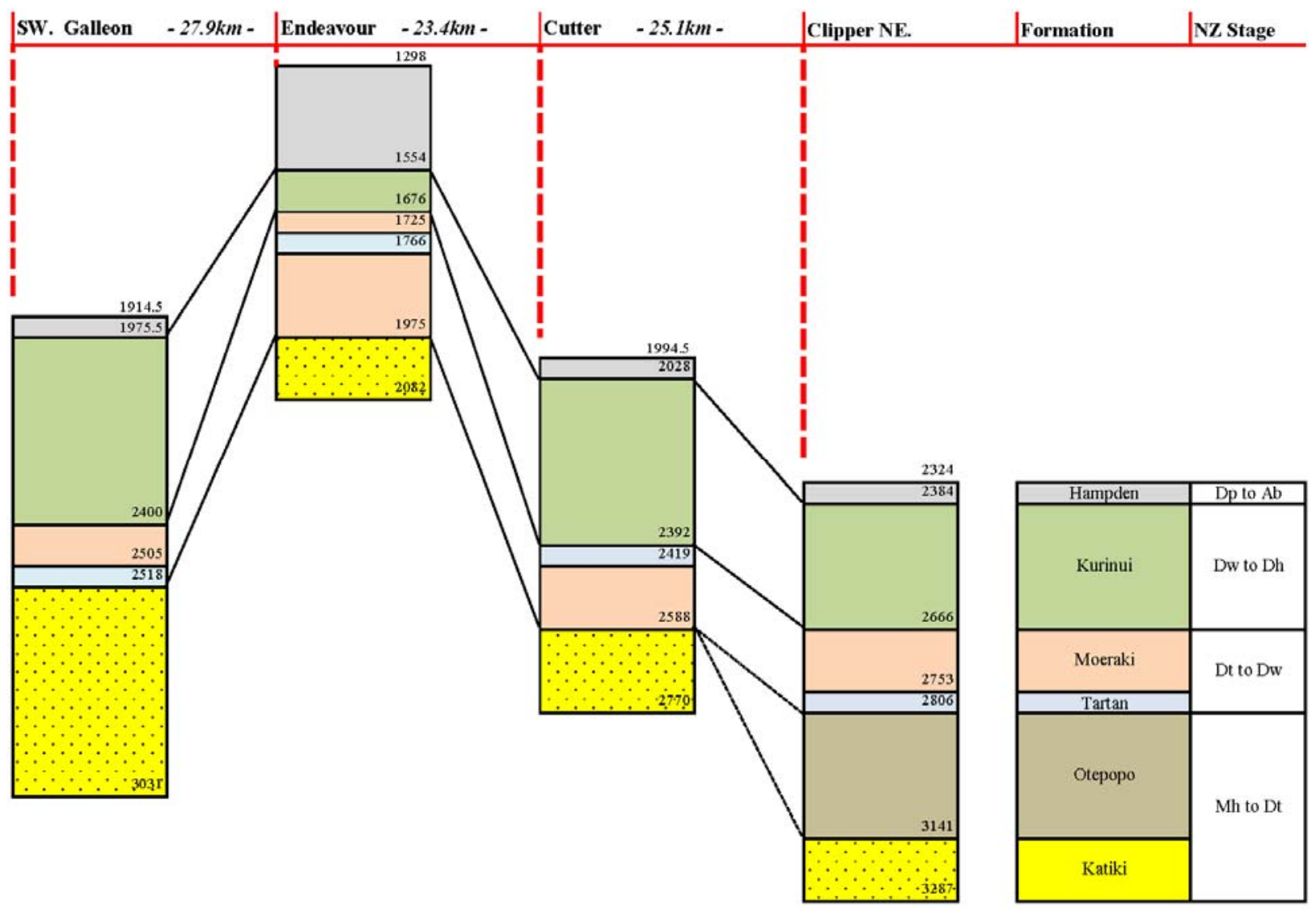

Figure 3.6: Clipper Sub-Basin: Generalised well stratigraphy.

Depths of formation tops are given in metres (mbrt) for each well. Key to formation names and stages are given to the right. Refer to Appendix $\mathrm{C}$ for further details.

\begin{tabular}{|c|c|c|c|c|c|c|}
\hline Series & Global Age & NZ Stage & Formation & Lithology & Depositional Environment & Thickness \\
\hline \multirow{6}{*}{ 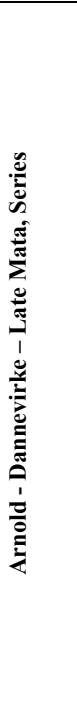 } & $\begin{array}{l}\text { Late Maastrichtian - early } \\
\text { Ypresian }\end{array}$ & Mh-Dt & Katiki & $\begin{array}{l}\text { Medium dark grey, } \\
\text { massive, silty to } \\
\text { muddy sandstone }\end{array}$ & $\begin{array}{l}\text { Inner-shelf with little wave } \\
\text { activity and slightly abnormal } \\
\text { salinity }\end{array}$ & c.a. $<515 \mathrm{~m}$ \\
\hline & $\begin{array}{l}\text { Early Danian - to late } \\
\text { Thaetian }\end{array}$ & $\mathrm{Dt}$ & Otepopo & $\begin{array}{l}\text { Light grey to light } \\
\text { grey/brown sandy } \\
\text { siltstone }\end{array}$ & Near shore to inner shelf. & $\begin{array}{l}\text { c.a. } 335 \mathrm{~m} \\
\text { Clipper-1 only }\end{array}$ \\
\hline & Danian - early Ypresian & $\mathrm{Dt}-\mathrm{Dw}$ & Moeraki & $\begin{array}{l}\text { Medium grey-green } \\
\text { mudstone }\end{array}$ & $\begin{array}{l}\text { Inner shelf deposition with a } \\
\text { possible outer neritic to bathyal } \\
\text { paleoenvironment competent }\end{array}$ & c.a. $<300 \mathrm{~m}$ \\
\hline & $\begin{array}{l}\text { Late Thanetian - early } \\
\text { Ypresian }\end{array}$ & $\mathrm{Dt}-\mathrm{Dw}$ & Tartan & $\begin{array}{l}\text { Dark brown, } \\
\text { carbonaceous shale }\end{array}$ & $\begin{array}{l}\text { Shelf to basal slope/abyssal } \\
\text { environment below the limit of } \\
\text { wave action }\end{array}$ & c.a. $<41 \mathrm{~m}$ \\
\hline & $\begin{array}{l}\text { Early Ypresian to early } \\
\text { Lutetian }\end{array}$ & Dw - Dh & Kurinui & $\begin{array}{l}\text { Medium grey } \\
\text { mudstone }\end{array}$ & $\begin{array}{l}\text { An inner to middle shelf } \\
\text { environment which was affected } \\
\text { by periodic storm events }\end{array}$ & c.a. $<425 \mathrm{~m}$ \\
\hline & $\begin{array}{l}\text { Early Lutetian - early } \\
\text { Bartonian }\end{array}$ & $\mathrm{Dh}-\mathrm{Ab}$ & Hampden & $\begin{array}{l}\text { Medium grey } \\
\text { mudstone. }\end{array}$ & $\begin{array}{l}\text { An outer most shelf to upper } \\
\text { bathyal environment }\end{array}$ & c.a. $<257 \mathrm{~m}$ \\
\hline
\end{tabular}

Table 3.1: Clipper Sub-Basin: Summary of late Mata Series to early Arnold Series formation used in this thesis. Formation age, basic lithology, interpreted depositional environment and thickness are illustrated. 
1. Katiki Formation.

The Katiki Formation is a medium dark grey, massive, silty to muddy sandstone. Grain size decreases stratigraphically upwards to a siltstone (McMillian, 1999). The formation was deposited between the Haumurian $(\mathrm{Mh})$ at the base and the Teurian (Dt) at the top; the fining upward nature suggests deposition occurred in a deepening offshore setting (Morgans, 2009) (Figure 3.7). Abundant pyrite, glauconitic and bioturbation suggest an inner shelf environment with little wave activity and slightly subnormal salinity (Pocknall et al., 1991). Towards the southwest of the basin in the vicinity of Endeavour-1 and Galleon-1, the Katiki Formation is interrupted locally by Pukeiwitahi Formation, the Zapata Limestone and the Galleon Volcanics.

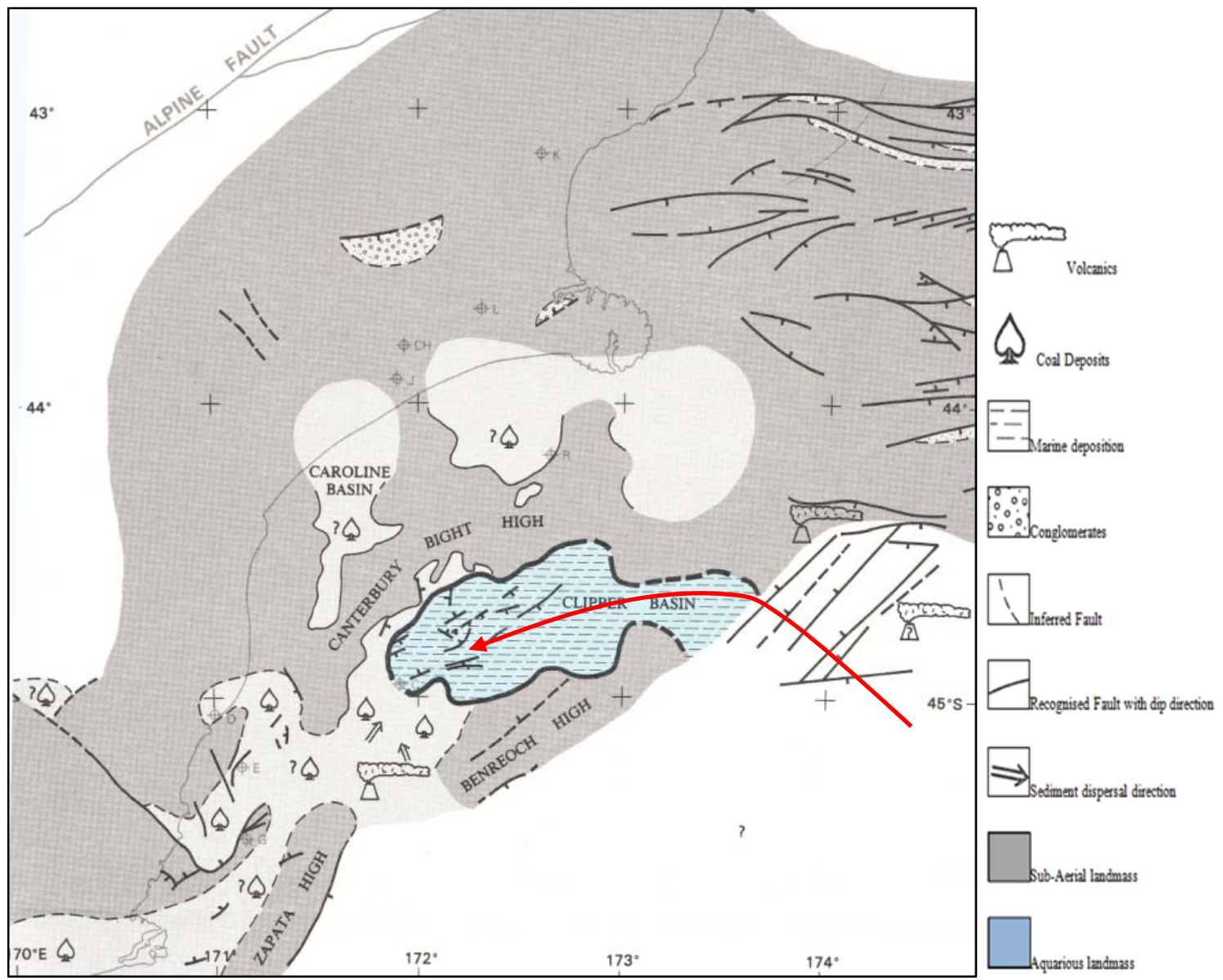

Figure 3.7: Canterbury Basin: Lower Mata Series paleogeography.

The sea entered from the east and northeast (red arrow) into the Clipper Sub-Basin. Infilling of the Clipper Sub-Basin was influenced by the emerging Zapata and Benreoch High and Galleon volcanics which periodically interrupt the Katiki Formation deposition. Transgressive marine sediments also begin to seal non-marine to estuarine coal measures of the Pukeiwitahi Formation. Sub-basin development also occurring north of the Canterbury Bight High. Coal deposits continue to form in the Clipper Sub-Basin. Modified after Field and Browne (1989).

\section{Moeraki Formation}

The Moeraki Formation is a medium grey green, micaceous, non-calcareous mudstone (Morgans, 2009). It was deposited between lower to middle Teurian (Dt) at the base and upper Teurian to lower Waipawan $(\mathrm{Dw})$ at the top. The Moeraki Formation is recognised by a marked decrease in 
glauconite content from the high proportion of greensand observed in the Otepopo Formation and has a relatively high gamma signature on wireline logs.

The Moeraki Formation appears to be thickest in the vicinity of Endeavour-1, thinning towards the southeast of the basin (Figure 3.8). This formation is highly bioturbated suggesting inner shelf deposition (Wilson \& McMillan, 1996). An outer neritic to bathyal paleoenvironment may also be interpreted with basinward regression based on microfaunas and microfloras observed by Pocknall et.al; (1991) and Field and Browne (1989).



Figure 3.8: Canterbury Basin: Lower Dannevirke Series paleogeography.

During this period, continued subsidence resulted in widespread flooding to shelf and bathyal depths. The shoreline has transgressed west, depositing fine grained sediments of the Katiki and Moeraki formations, which are now widespread. In shallow water areas, neritic sandstone and deltas developed, with estuarine coal and non-marine facies further westward. Modified after Field and Browne (1989).

\section{Tartan Formation}

The Tartan Formation is a dark brown, carbonaceous, slightly calcareous, very micaceous, and slightly glauconitic shale (Cook et al., 1999 and Schiøler, et al., (2010). The Tartan Formation is biostratigraphically coeval with the Waipawa Formation of the New Zealand East Coast, Taranaki and Northland Basins. It is also identified throughout the Great South and Canterbury Basins. It is 
Late Teurian (Dt) in age and has a very distinctive high gamma signature usually in the order of 150API - 180 API. Because of the widespread distribution of the Tartan Formation throughout New Zealand, it is difficult to assign one contemporaneous depositional environment. In the Canterbury Basin, the Tartan Formation, is anomalously rich in organic matter, is a result of changes in oceanic circulation patterns prior to the benthic extinctions of the late Paleocene warming (Crouch \& Brinkhuis, 2005). According to Schiøler et al., (2010) the Tartan Formation was deposited under dysaerobic conditions. This corresponds to an inner shelf to basal slope/abyssal environment below the limit of wave action and areas of high phytoplankton productivity (Figure 3.8). 


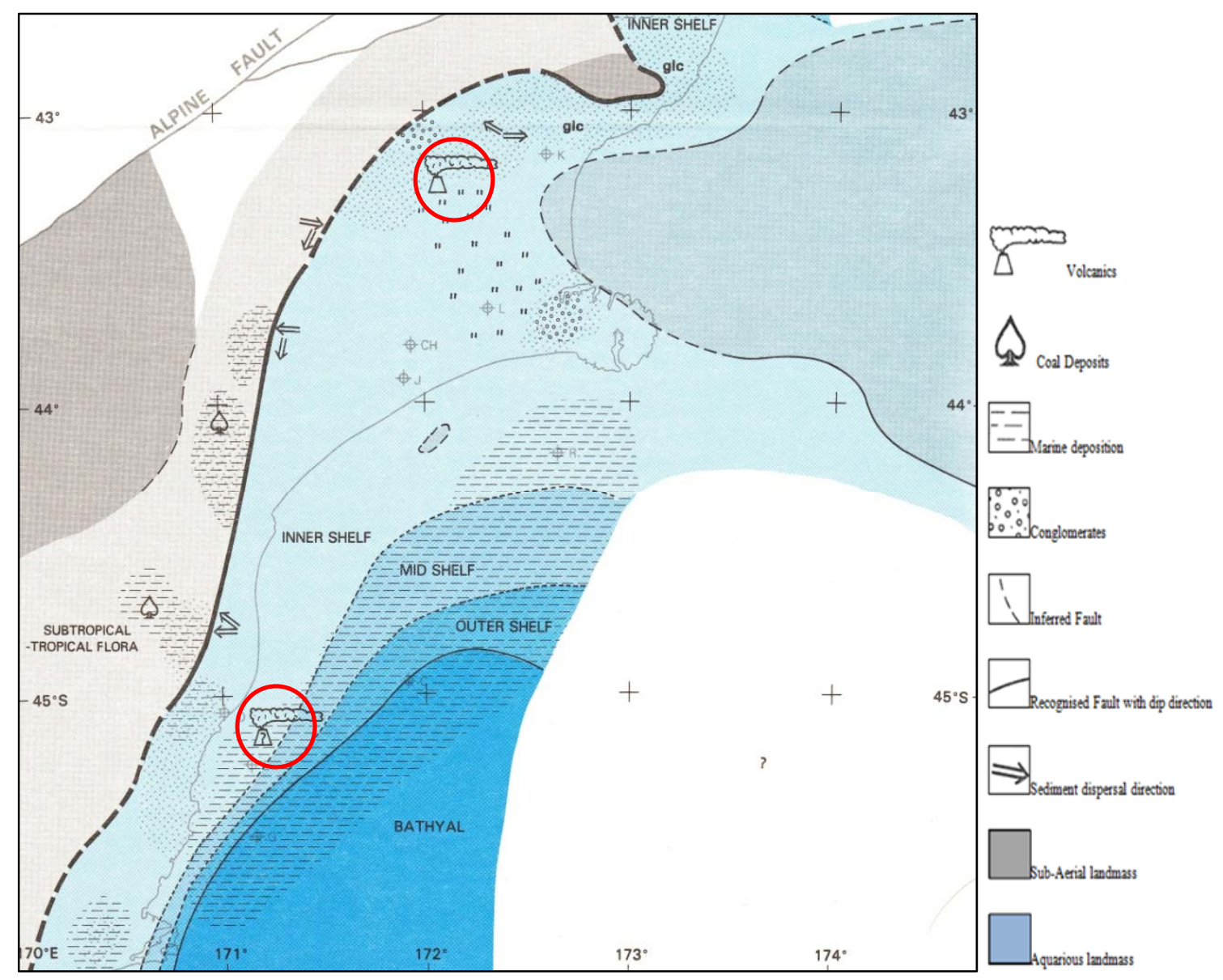

Figure 3.9: Canterbury Basin: Middle Dannevirke Series paleogeography.

Renewed volcanism (red circle) associated with the View Hill and Endeavour volcanics occurred concurrent with the development of fine-grained inner shelf to bathyal depositional environments. Modified after Field and Browne (1989).

\section{The Otepopo Formation}

This formation is a light grey to light grey/brown sandy siltstone which is highly argillaceous, soft, and glauconitic in appearance (Wilding and Sweetman 1971). Deposited during the lower Teurian (Dt) the Otepopo Formation exhibits a sharp basal contact; possibly being a disconformity. It is only observed in the Clipper-1 well.

\section{Kurinui Formation}

The Kurinui Formation is a medium grey, non-calcareous basal glauconitic greensand overlain by a fining upwards succession of slightly calcareous mudstone (Morgans, 2009). The glauconite content decreases into bioturbated smectite silty claystones with several muddy very fine sand layers (McMillian, 1999). Dinoflagellate and foraminiferal data indicate a Waipawan Heretaungan (Dw - Dh) age and an inner to middle shelf environment which was affected by periodic storm events is inferred (McMillian, 1999) (Figure 3.9). 


\section{Hampden Formation}

The Hampden Formation is a medium grey, calcareous, micaceous, thoroughly bioturbated, very fine sandstone which grades upwards into mudstone. Thick greensand at the base probably suggests a discontinuity on the underlying Kurinui Formation and therefore could be as old as Porangan (Dp) at the base (Morgans, 2009). Abundant macro and microfauna in the mudstone indicate a Bortonian - Kaiatan ( $\mathrm{Ab}$ - Ak) age and deposition is thought to have occurred in an outer most shelf to upper bathyal environment, (i.e. depositional environments deeper than other Dannevirke Series sediments) (Morgans, 2009) (Figure 3.10).

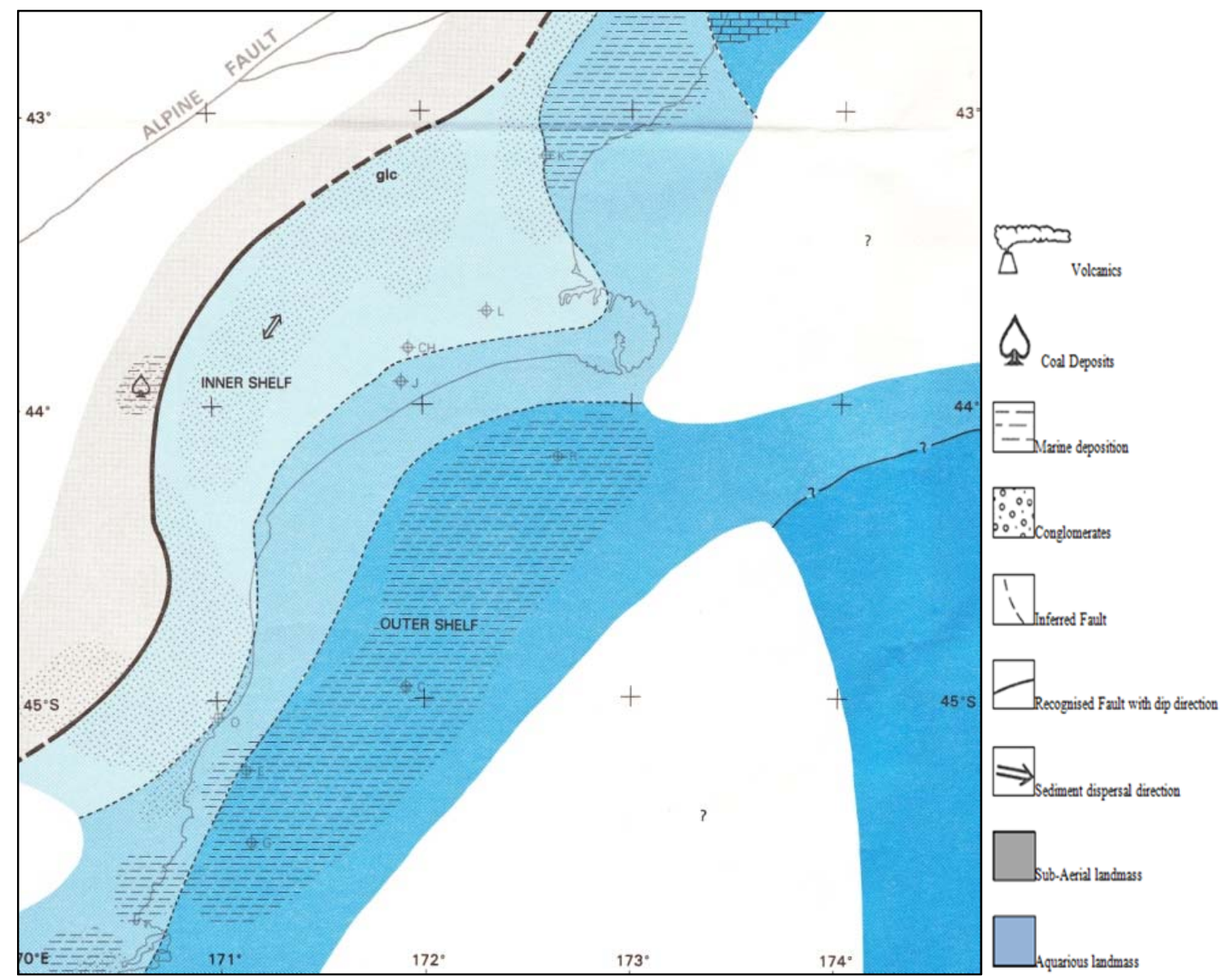

Figure 3.10: Canterbury Basin: Lower Arnold Series paleogeography.

Volcanism was quiescent and deposition was dominated by fine - grained sediments. The shoreline had transgressed west to approximate present day position. Development of inner shelf to bathyal depositional environments continues. Modified after Field and Browne (1989).

\section{Late Eocene to Early Miocene}

The Amuri Limestone is recognised as strata deposited between the Runangan (Ar) at the base to the Waitakian (Lw) at the top. It overlies the sediments of the Dannevirke Series (Figure 3.11 and Figure 3.12). Microfaunas present in the limestone suggest an outer shelf or slope paleoenvironment, which ultimately represents sediment starvation during the maximum transgression over the New Zealand landmass (Field and Browne, 1989). 


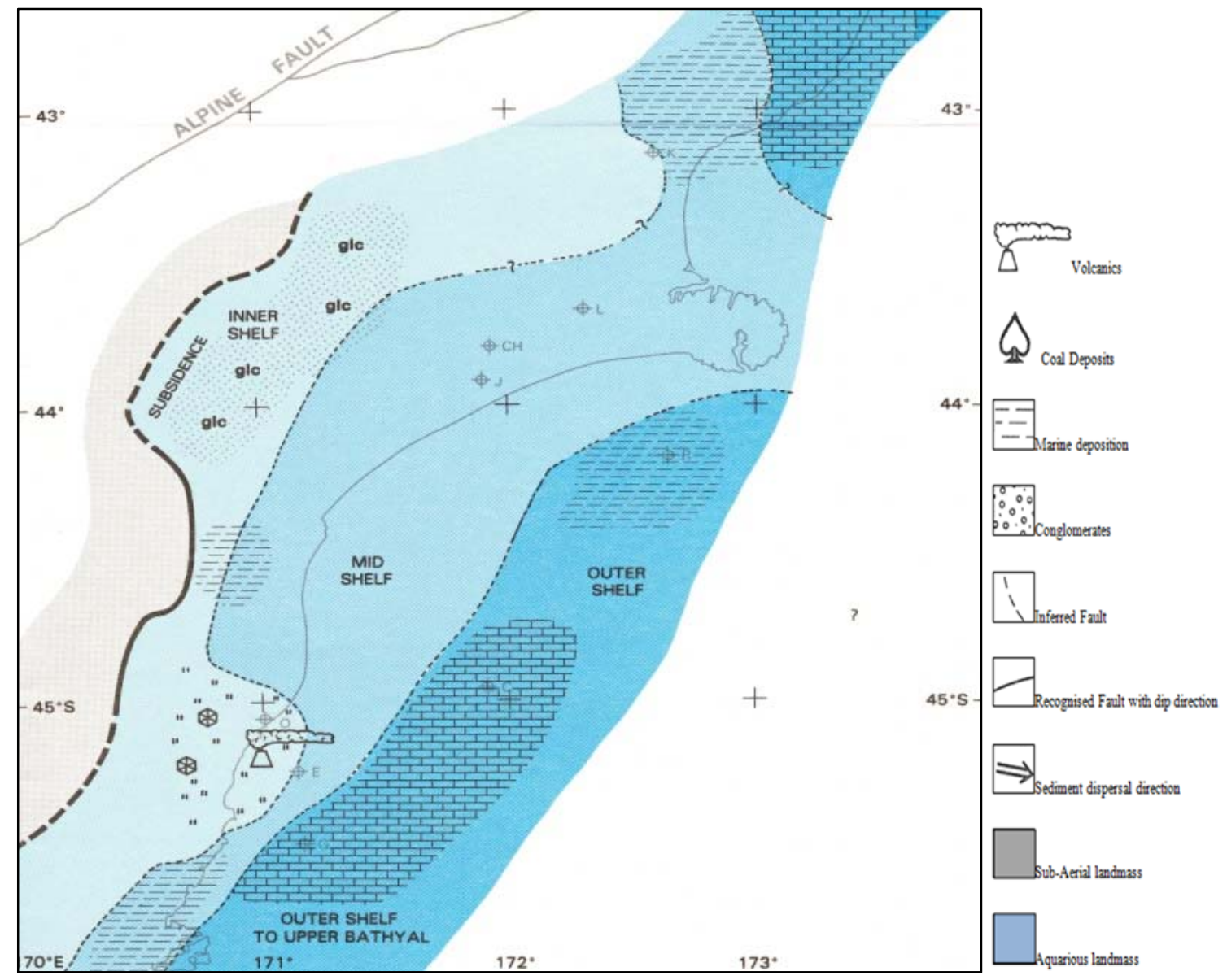

Figure 3.11: Canterbury Basin: Upper Arnold Series paleogeography.

Volcanism in the Canterbury Basin is characterised by alkalic to tholeitic widespread volcanism associated with the Brothers Basalt and Cookson Volcanics. Basin subsidence in the inner shelf environment leads to increased glauconitic deposition, while carbonate deposition in the outer shelf environment now commences to cover sediments of Dannevirke age. Modified after Field and Browne (1989). 


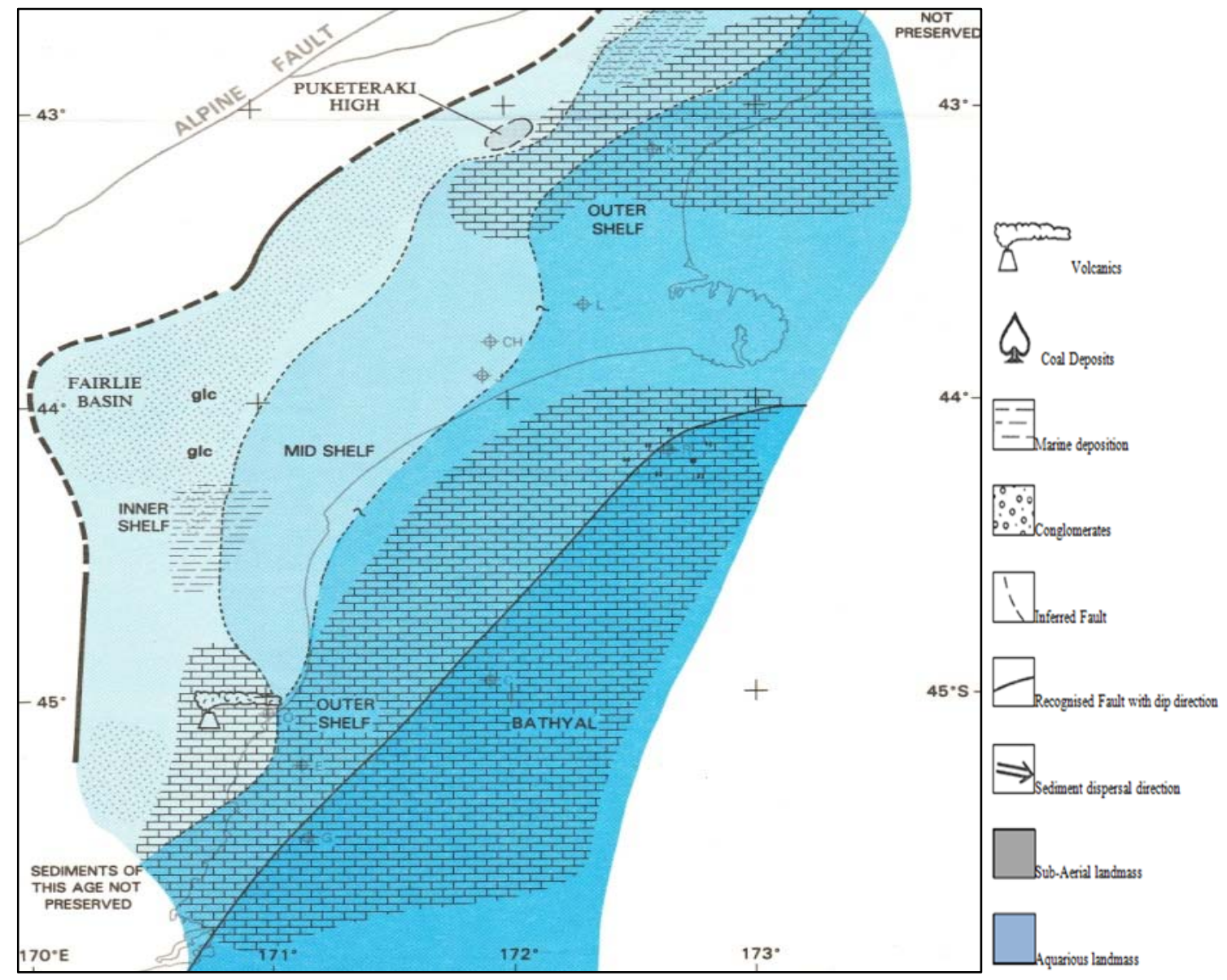

Figure 3.12: Canterbury Basin: Lower Landon Series paleogeography.

Volcanism in the Canterbury Basin is characterised by alkalic to tholeitic widespread volcanism associated with the Brothers Basalt and Cookson Volcanics. Increasing carbonate coverage continues to cover sediments of Dannevirke age. The Fairlie Basin also commences to receive glauconitic sediment, as shoreline develops westward. Modified after Field and Browne (1989).

Isopach map interpretation of the Clipper Sub-Basin indicate Paleogene sediment thickness is limited to two kilometres (Figure 3.13). Compared to the mid to late Cretaceous isopach, the Paleogene interpretation is widespread across the basin. Little or no faulting is observed. 


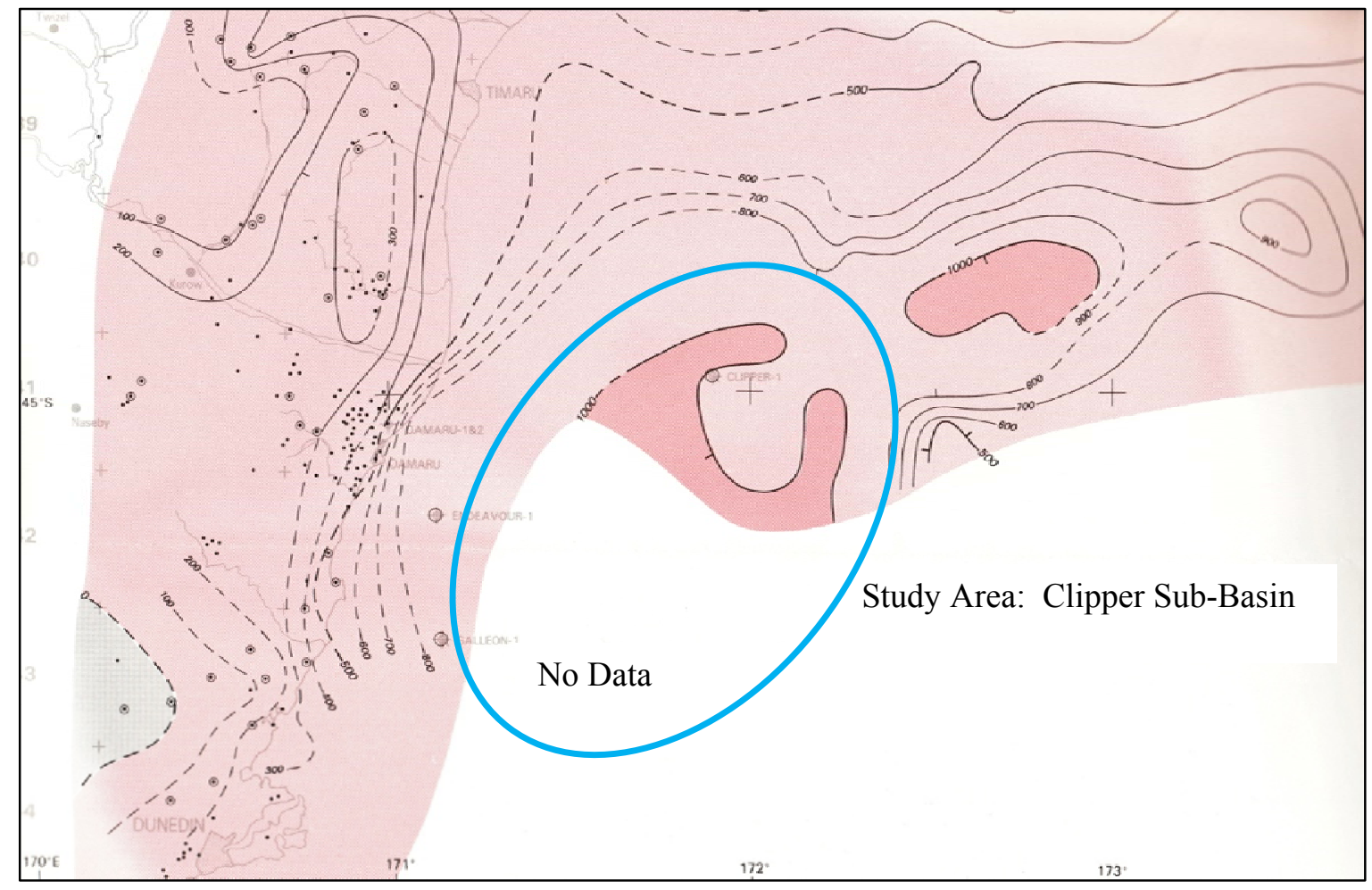

Figure 3.13: Canterbury Basin: Paleogene isopach map.

Circled in blue is the Clipper Sub-Basin which during the Paleogene is thought to exhibit up to 2 kilometres of transgressive sedimentation. Infilling contours are not completed understood towards the south and there is a large area with no interpretation. After Field and Browne (1989).

\subsection{Canterbury Basin: Neogene}

Compressional forces associated with the development of modern Australian - Pacific plate boundary to the east of the basin provided an additional sediment source for the rapidly subsiding sub-basins and reactivated older normal faults into reverse faults. By early Waitakian (Lw) time, two subduction zones along the Puysegur and Hikurangi margins were affecting the fault geometry of the Canterbury Basin (Field \& Browne, 1989; Field et al., 2002). East-west compression observed north of the basin was becoming pronounced while increased regional subsidence occurred to the south. During this time (28.5 $20.5 \mathrm{Ma}$ ) the Canterbury Basin experienced deposition of Whaingaroan (Lwh) to Otaian (Po) carbonate sediments together with greensand (glauconite) deposition and basaltic volcanisim (at Oamaru, Timaru, Geraldine and Banks Peninsula). Increased subsidence and tectonic uplift resulted in sediment progradation from west to east (Field \& Browne, 1989; Lu et al., 2003). Two mechanisms controlled this accelerated sedimentation during the Miocene; a positive relationship between plate convergence and uplift in the Southern Alps and global climatic and eustatic forcing mechanisms. This resulted in the preservation of an unusually thick sedimentary wedge which offshore is well imaged in seismic reflection surveys with numerous depositional cycles revealed (Lu et al., 2005).

Noted in seismic records in the late Miocene is an increased warping and uplift signature of this clastic sediment ( $\mathrm{Lu}$ et al., 2005). Field \& Browne (1989) attributes the evolution of Banks Peninsula volcanics to this warping and uplift with continuous activity from $11-5.8 \mathrm{Ma}$. The late Miocene to early Pliocene is 
characterised by a glacioeustatic fluctuation in sea level causing more regional erosion and unconformities (Suggate, 1990). Extensive erosion (which was particularly great in the west) gave rise to thick sheets of Pliocene sand and conglomerate (Kowai Formation) being deposited. This conglomerate wedge prograded east and interfingers with fine grained marine sediments. Increasing frequency and amplitude of climate change (Molnar, 2004) and deformation associated with the Kaikoura Orogeny, particularly in the north of the basin continued into the Pleistocene (Browne \& Naish, 2003).

The Pleistocene is characterised by increased plate convergence and continued uplift of the Southern Alps (Norris \& Cooper, 2000). It is also marked by frequent periods of glaciation and associated fluctuations in sea level (Field \& Browne, 1989; Suggate, 1990; Browne \& Naish, 2003).

Isopach map interpretation of the Clipper Sub-Basin indicate Neogene sediment thickness is limited to two kilometres (Figure 3.14). Compared to the mid to late Cretaceous isopach, the Paleogene interpretation is regular with transgressive infilling of Cretaceous graben features near to complete. Little or no faulting is observed.

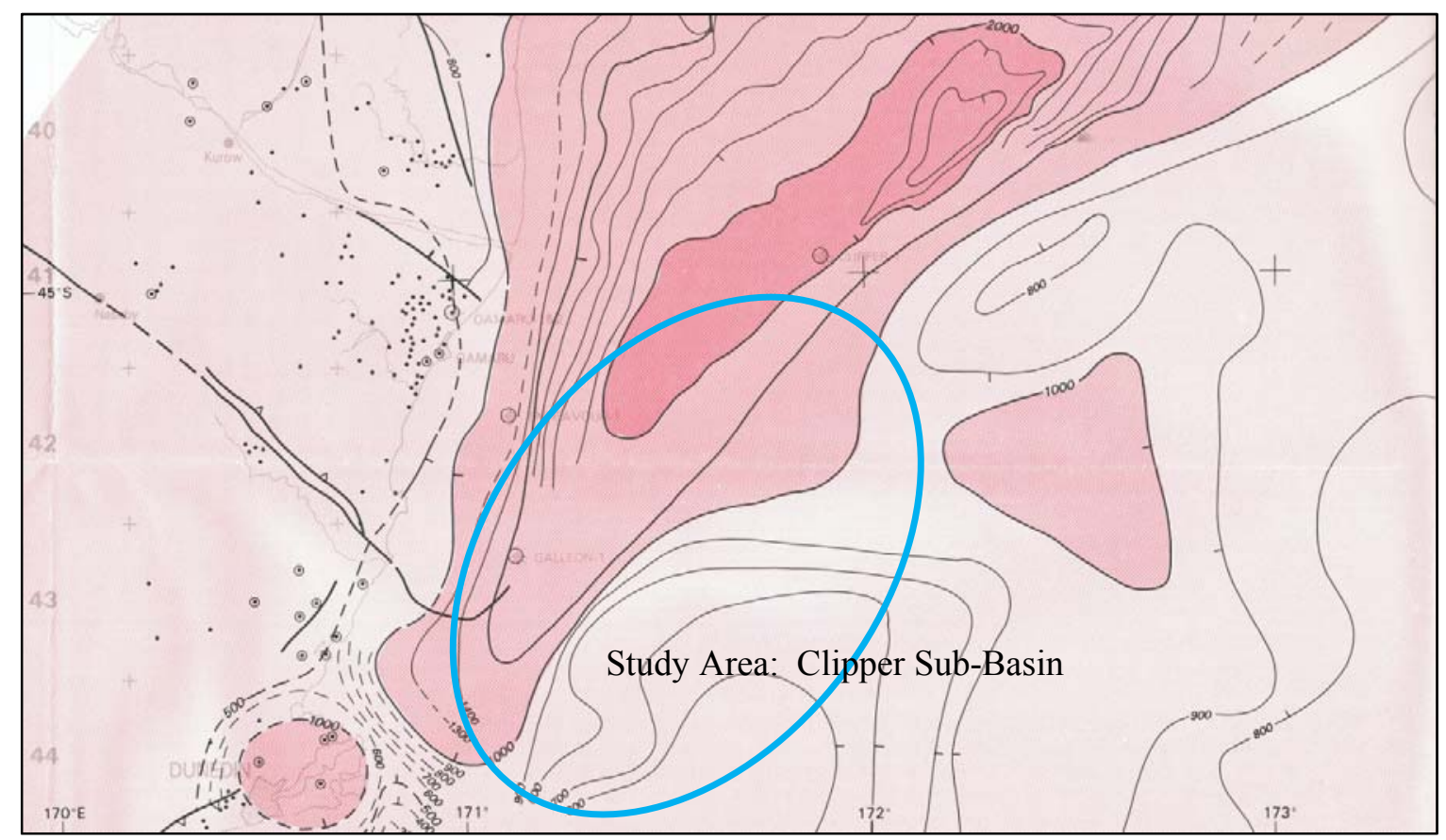

Figure 3.14: Canterbury Basin: Neogene isopach map.

Circled in blue is the Clipper Sub-Basin which during the Neogene maintained a NE SW trending depocentre as noted in the mid to late Cretaceous isopach map. Up to two kilometres of sediment was deposited during this period; in response principally to regional uplift on the South Alps and in the deposition of material into the basin. After Field and Browne (1989). 


\subsection{Study Methods}

\subsection{General introduction}

Shale gas must be stored as free gas in either naturally occurring fractures or throughout intergranular porosity in sufficient volume to be considered economic (Law, 2002). Siliceous mineralogy may also control enhanced secondary porosity, by means of preferentially fracturing fine grained facies; as is the case for shale gas accumulations in the Barnett Shale, Texas and the Monterery Formation, Caifornia (Chaika \& Williams, 2001; Jarvie et al., 2007 and Durham, 2010). Higgs, (2007) identified elevated silica accumulations in intervals of elevated total gas in mudstones in Cutter-1. It is therefore conceivable shale gas may be accumulating in similar facies through out the Clipper Sub-Basin.

To investigate this hypothesis, this thesis has employed; thin sections, X-Ray Diffraction (XRD), Scanning Electron Microscopy (SEM), Rock-Eval pyrolysis techniques and relating findings such as wireline log signatures to determine the relationship between mineralogy and gas accumulation in the Clipper Sub-Basin.

\subsection{Thin Sections}

Thin section preparation followed standardised methods, namely a $0.03 \mathrm{~mm}$ thick slice of a sample mounted upon a glass slide was made, allowing almost the entire range of grains sizes in a sample to be examined under a polarizing microscope (Shelley, 1975). Preparation of the samples is briefly discussed:

1. Washed cutting samples were collected over reference intervals from Endeavour-1; Galleon-1; Clipper-1 and Cutter-1.

2. Samples were impregnated with epoxy resin in a vacuum chamber to ensure air bubbles were minimal during preparation.

3. The epoxy 'plugs' which contain the sample are cut to approximately $2 \mathrm{~mm}$ thickness using a diamond cutting saw and cut faces were smoothed down using fine abrasives (carborundum power) mixed with water.

4. The smooth cut faces were mounted onto a glass slide, allowed to set before final smoothing down of sampled mount to an approximate $0.03 \mathrm{~mm}$ thickness.

5. Slides were washed in alcohol and stained using potassium ferrocyanide which turns yellow under normal polar in the presence of potassium feldspar.

Twenty samples from Dannevirke age mudstones were examined using a polarizing microscope (Table 4.1). All samples prepared have been sourced from washed cutting samples. Considerable care was taken when interpreting thin sections and only analysis representative and consistent with overall mudstone facies was considered (i.e. downhole contamination from limestone facies is not considered representative). All samples were stained for orthoclase feldspar (orthoclase appears yellow under normal 
polar) and point counting was carried out on sand grains identified throughout the slides. One hundred sand sized grains were counted per sample and plotted on a Quartz, Feldspar, Lithic (QFL) plot (after Folk, et al., 1970).

\begin{tabular}{l|l|l|l|l} 
Formation & Endeavour-1 & Galleon-1 & Clipper-1 & Cutter-1 \\
\hline Hampden & $1500 \mathrm{~m}$ & & & \\
\hline Kurinui & $1600 \mathrm{~m}$ & $2300 \mathrm{~m}$ & & $2110 \mathrm{~m}$ \\
\hline & & & & $2140 \mathrm{~m}$ \\
\hline & & & & $2390 \mathrm{~m}$ \\
\hline Tartan & $1750 \mathrm{~m}$ & $2500 \mathrm{~m}$ & & \\
\hline Moeraki & $1760 \mathrm{~m}$ & & & \\
\hline & & $2450 \mathrm{~m}$ & & $2430 \mathrm{~m}$ \\
\hline & & & & $2560 \mathrm{~m}$ \\
\hline Otepopo & & & & \\
\hline & & & $3000 \mathrm{~m}$ & \\
\hline Katiki & & & $3100 \mathrm{~m}$ & \\
\hline & & $2550 \mathrm{~m}$ & & $2640 \mathrm{~m}$ \\
\hline & & $2650 \mathrm{~m}$ & & $2660 \mathrm{~m}$
\end{tabular}

Table 4.1: Clipper Sub-Basin: Dannevirke Series thin section sample selection.

Washed cutting samples are expressed in metres below rotary table (mbrt).

\subsection{X-Ray Diffraction}

X-ray diffraction is used extensively for analysing the structure and properties of solid materials. Produced from photons of electromagnetic radiation instead of transitions between radioactive nuclei (as in a gamma ray), X-rays have the ability to penetrate different matter, as a function of density and elemental composition. As the primary beam strikes the sample, x-rays are diffracted in a characteristic manner; this pattern is recorded on a radiation counter as abundance peaks.

A brief description of how the washed samples were prepared follows:

1. Samples were crushed in an agate mortar and pestle and prepared in unoriented powder mounts.

2. The $<2 \mu \mathrm{m}$ clay fraction was separated and two oriented clay mounts were prepared for each sample, one of these was run as an untreated scan and the other was run after glycolation to verify the presence of any swelling clays.

3. Partial semi-quantitative X-Ray Florescence (XRF) was carried out on some samples to assist and confirm XRD confirmations.

Quantitative whole rock and clay fraction XRD analysis was undertaken on 12 mudstone samples from the Clipper Sub-Basin exploration wells (Table 4.2). These samples were tested by Sietronics Pty Limited in Canberra. Additional quantitative whole rock and clay fraction XRD analysis carried out by Higgs (2007) on behalf of TAP Oil (Cutter-1) were also used in this study.

\begin{tabular}{l|l|l|l|l|l} 
Formation & Endeavour-1 & Galleon-1 & Clipper-1 & Cutter-1 & Cutter-1 \\
\hline Hampden & $1500 \mathrm{~m}$ & & & & $2142.5 \mathrm{~m}$ \\
\hline Kurinui & $1600 \mathrm{~m}$ & & & $2110 \mathrm{~m}$ & $2142.5 \mathrm{~m}$ \\
\hline & & & & $2390 \mathrm{~m}$ & \\
\hline & & & & & $2161 \mathrm{~m}$ \\
\hline & & & & & $2183.5 \mathrm{~m}$ \\
\hline & & & & & $2199.5 \mathrm{~m}$ \\
\hline
\end{tabular}




\begin{tabular}{l|l|l|l|l|l}
\hline & & & & & \\
\hline Tartan & $1750 \mathrm{~m}$ & $2500 \mathrm{~m}$ & & & $260 \mathrm{~m}$ \\
\hline Moeraki & & $2450 \mathrm{~m}$ & & $2505 \mathrm{~m}$ & $2360 \mathrm{~m}$ \\
\hline & & & & & \\
\hline & & & & & $2516 \mathrm{~m}$ \\
\hline & & & & & $2521 \mathrm{~m}$ \\
\hline Otepopo & & & $3000 \mathrm{~m}$ & & $2526 \mathrm{~m}$ \\
\hline & & & $3100 \mathrm{~m}$ & & \\
\hline Katiki & & $2550 \mathrm{~m}$ & $3150 \mathrm{~m}$ & & $2640 \mathrm{~m}$
\end{tabular}

Table 4.2: Clipper Sub-Basin: Dannevirke Series XRD sample selection.

Washed cutting samples are expressed in metres below rotary table (mbrt). Shaded column denotes previous XRD work carried out by Higgs (2007) on Cutter-1 samples collected.

Although it is unknown what analytical method Higgs (2007) adopted, when examining samples from Cutter-1, Sietronics adopted the following parameters to produce an XRD pattern (Table 4.3).

\begin{tabular}{ll} 
Model: & Bruker-AXS D4 XRD \\
\hline Generator: & $40 \mathrm{kV} \& 30 \mathrm{~mA}$ \\
\hline Tube Anode: & Copper \\
\hline Wave Length: & $1.54 \AA$ \\
\hline Step Spacing: & $0.02^{\circ}$ \\
\hline Scan Step Time: & 2 seconds \\
\hline Divergent Slit: & Automatic \\
\hline Scanning Range: & $1.3^{\circ}$ to $70^{\circ}$ \\
\hline Spinning: & Yes \\
\hline Quantitative Software: & Siroquant Version 3
\end{tabular}

Table 4.3: Clipper Sub-Basin: Dannevirke Series XRD procedure settings.

\subsection{Scanning Electron Microscope and Energy Dispersive Spectroscopy}

The Scanning Electron Microscope (SEM) is a tool increasingly used by petroleum geologists to evaluate reservoir quality, identifying microfossils, and to address production problems associated with clay minerals and drilling fluids. Unlike a polarising microscope which records a two dimensional image of a sample, the SEM produces a three dimensional image. This has allowed the pore structures and the smallest associated minerals to be identified (Welton, 1984).

Instead of using a ray of light the SEM utilises an internally generated electron beam, known as the primary beam. In scanning electron microscopy, (SEM) an electron beam is scanned across a sample's surface. When the electrons strike the sample, a variety of signals are generated, and it is the detection of specific signals which produces an image or a sample's elemental composition. The three signals which provide the greatest amount of information in SEM are; 1) secondary electrons; 2) backscattered electrons; and 3) X-rays.

Secondary electrons are emitted from the atoms occupying the top surface and produce a readily interpretable image of the surface. The contrast in the image is determined by the sample morphology. A high-resolution image can be obtained because of the small diameter of the primary electron beam. Backscattered electrons are primary beam electrons which are 'reflected' from atoms in the solid. The 
contrast in the image produced is determined by the atomic number of the elements in the sample. The image will therefore show the distribution of different chemical phases in the sample (Welton, 1984). Because these electrons are emitted from a depth in the sample, the resolution in the image is not as good as for secondary electrons. Interaction of the primary beam with atoms in the sample causes phase transitions which result in the emission of an X-ray. The emitted X-ray has an energy characteristic of the parent element. Detection and measurement of the energy permits elemental analysis (Energy Dispersive X-ray Spectroscopy (EDS).

EDS can provide rapid qualitative, or with adequate standards, quantitative analysis of elemental composition with a sampling depth of 1 to 2 microns. X-rays may also be used to form maps or line profiles, showing the elemental distribution in a sample surface.

Preparation of the samples for SEM and EDS scanning are as follows:

1. Dried grains were stuck to an adhesive strip of conductive carbon tape; which was mounted onto an aluminium 'stub'.

2. These 'stubs' were coated first in carbon and secondly platinum using an evaporative coating chamber to ensure a clear image and to prevent damage.

SEM and EDS methods used to examine intervals of elevated quartz content found in the four reference wells. SEM is capable of magnifying a sample image up to 150000 times, and is therefore capable of identifying elementary architecture that may be considered biogenic or detrital. Silica based planktonic species include radiolarian and diatoms; two levels of marine taxonomy. Twenty samples were examined taken from intervals where elevated silica (derived from XRD results) was observed (Table 4.4). 


\begin{tabular}{|c|c|c|c|c|}
\hline Formation & Endeavour-1 & Galleon-1 & Clipper-1 & Cutter-1 \\
\hline \multirow[t]{2}{*}{ Hampden } & $1400 \mathrm{~m}$ & & & \\
\hline & $1500 \mathrm{~m}$ & & & \\
\hline \multirow[t]{4}{*}{ Kurinui } & $1600 \mathrm{~m}$ & & & $2100 \mathrm{~m}$ \\
\hline & & & & $2145 \mathrm{~m}$ \\
\hline & & & & $2155 \mathrm{~m}$ \\
\hline & & & & $2180 \mathrm{~m}$ \\
\hline \multirow{4}{*}{$\begin{array}{l}\text { Tartan } \\
\text { Moeraki }\end{array}$} & $1750 \mathrm{~m}$ & $2505 \mathrm{~m}^{*}$ & & \\
\hline & $1800 \mathrm{~m}$ & $2400 \mathrm{~m}$ & & $2430 \mathrm{~m}^{*}$ \\
\hline & & $2450 \mathrm{~m}$ & & $2530 \mathrm{~m}$ \\
\hline & $1850 \mathrm{~m}$ & & & \\
\hline \multirow[t]{3}{*}{ Otepopo } & & & $3000 \mathrm{~m} *$ & \\
\hline & & & $3050 \mathrm{~m}$ & \\
\hline & & & $3100 \mathrm{~m} *$ & \\
\hline \multirow[t]{2}{*}{ Katiki } & & $2550 \mathrm{~m}$ & $3150 \mathrm{~m}$ & \\
\hline & & $2600 \mathrm{~m}$ & $3250 \mathrm{~m}$ & \\
\hline
\end{tabular}

Table 4.4: Clipper Sub-Basin: Dannevirke Series SEM \& EDS sample selection.

Washed cutting samples are expressed in metres below rotary table (mbrt). * Samples examined and mapped using the EDS technique.

\subsection{Total Organic Carbon and Rock-Eval Pyrolysis}

Certain minimum values of TOC are required before the expulsion of hydrocarbons from a source rock can occur. Typical expulsion thresholds are considered to be $0.3 \%$ for carbonates and $0.5 \%$ for shales (Tissot \& Welte, 1978). A common way to measure TOC is by the Rock-Eval/TOC method, whereby Rock-Eval pyrolysis is combined with an oxidation cycle; effectively adding the organic carbon in the pyrolysate $\left(\mathrm{S}_{1}+\mathrm{S}_{2}\right)$ to the residual organic matter obtained by oxidisation $\left(\mathrm{S}_{4}\right)$.

A Source Rock Analyser (SRA TPH/TOC'M Model) at GNS Science was used in this research to determine; 1) the free hydrocarbons contained in the sample; and 2) the hydrocarbon and oxygen containing compounds $\left(\mathrm{CO}_{2}\right)$ that are volatilised during the cracking of kerogen. Cutting samples were soaked in warm water and washed over a $1 \mathrm{~mm}$ sieve before being dried at c.a. $40^{\circ} \mathrm{C}$. Samples were powdered and approximately $100 \mathrm{mg}$ was collected for pyrolysis testing. Eight samples obtained from Cutter-1 were processed using the following method:

1. Samples are kept isothermally at $300^{\circ} \mathrm{C}$ for 3 minutes, allowing the free hydrocarbons to be volatilised and their S1 peak measured, which is achieved using a Flame Ioniser Detector (FID).

2. The temperature was then increased from $300^{\circ} \mathrm{C}$ to $650^{\circ} \mathrm{C}$ (at $25^{\circ} \mathrm{C} / \mathrm{min}$ ). This is the phase of volatilisation of the heavier hydrocarbon compounds $(>\mathrm{C} 40)$ as well as the cracking of nonvolatile organic matter. The hydrocarbons released from this thermal cracking were measured as the S2 peak. The temperature at which S2 reaches its maximum corresponds to the maximum release of hydrocarbons from cracking of kerogen and is known as Tmax. 
3. The $\mathrm{CO}_{2}$ released from kerogen cracking is confined up to $400^{\circ} \mathrm{C}$. The kerogen confined to this temperature range, and $\mathrm{CO} 2$ which is released is expressed as the $\mathrm{S} 3$ peak.

4. The oven was then cooled below $600^{\circ} \mathrm{C}$ to ensure no pyrolysis components were released during oxidation and isothermally held at $580^{\circ} \mathrm{C}$ while the sample was saturated with oxygen to oxidise the remaining residual organic carbon. Carbon monoxide and carbon dioxide were measured to determine the value of S4 (Figure 4.1).

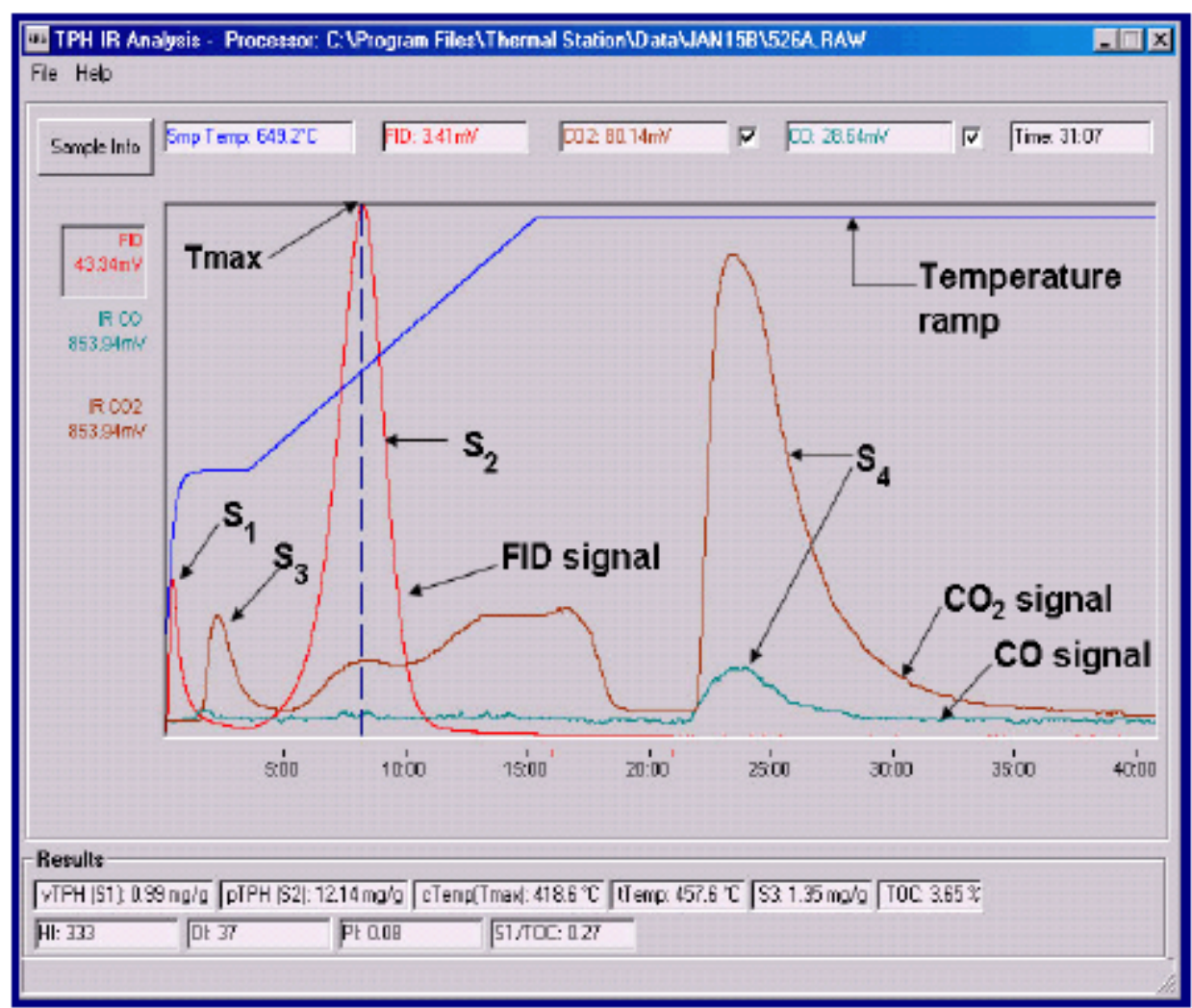

Figure 4.1: Source Rock Analyser (SRA) programme.

The SRA uses one oven and $S_{1}, S_{2}$ and $S_{3}$ peaks are measured simultaneously. The $X$-axis denotes the time domain; the $Y$ axis denotes temperature and $\mathrm{CO}, \mathrm{CO}_{2}$ intensity.

This process yields the following results:

1. S1. This is the amount of free hydrocarbons (gas and oil) in the sample (expressed as $\mathrm{mg} \mathrm{HC} / \mathrm{g}$ rock). Care must be taken interpreting samples which may be contaminated by drilling fluids (e.g. glycol mud additives, as used in Cutter-1) which can give an abnormally high value for $\mathrm{S}_{1}$.

2. S2. This is the amount of hydrocarbons generated through thermal cracking of non-volatile organic matter. $S_{2}(\mathrm{mg} \mathrm{HC} / \mathrm{g}$ rock) is an indication of the quantity of hydrocarbons that the rock has the potential of producing should burial and maturation continue.

3. S3. This is the amount of $\mathrm{CO}_{2}$ produced during pyrolysis of kerogen. $\mathrm{S}_{3}(\mathrm{mg} \mathrm{CO} / \mathrm{g}$ rock) is an indication of the amount of oxygen in the kerogen and is used to calculate the oxygen index. The 
measurement of $S_{3}$ is restricted to the range $300-400^{\circ} \mathrm{C}$ in order to exclude the possible addition of inorganic carbon from the thermal degradation of any carbonates present within the sample.

4. S4. This is the amount of carbon dioxide and carbon monoxide released during combustion of the residual organic carbon remaining after pyrolysis. The unit of measurement is $\mathrm{mg} \mathrm{CO}_{2} / \mathrm{g}$ rock.

5. Tmax. This is the temperature at which the maximum release of hydrocarbons from cracking of kerogen occurs during pyrolysis (i.e. the temperature of the S2 peak, Figure 4.1). Tmax is an indication of the level of maturation of the organic matter (Peters \& Cassa, 1994).

6. Total Organic Carbon (TOC) of the sample is obtained by oxidising the organic matter remaining in the sample after pyrolysis (residual organic carbon). The TOC is then determined by adding the residual organic carbon detected, to the pyrolysed organic carbon, which in turn is measured from the hydrocarbon compounds given off from pyrolysis.

7. Hydrogen index (HI), the parameter used to characterise the origin of organic matter is expressed by:

Equation 4.1: Hydrogen Index (HI) calculation.

$$
H I=(100 . S 2) / T O C
$$

8. Oxygen Index (OI), the parameter that correlates the ratio of oxygen to carbon is expressed by:

Equation 4.2: Oxygen Index (OI) calculation.

$$
O I=(100 . S 3) / T O C
$$

9. Production Index (PI), is used to characterise the evolution level of the organic matter and is expressed by:

$$
P I=\{S 1 /(S 1+S 2)\}
$$

Eight samples were examined from the Cutter-1 well only; the most recently drilled well in the Canterbury Basin (Table 4.5). These samples were selected in intervals of elevated background gas, as noted during drilling operations (Tap Oil Limited, 2007 ). 


\begin{tabular}{l|c|c} 
Formation & Depth (mbrt) & Gas Chromatograph Total Gas Reading (\%) \\
\hline Kurinui & 2145 & $0.13 \%$ \\
\hline Kurinui & 2155 & $1.40 \%$ \\
\hline Kurinui & 2180 & $0.46 \%$ \\
\hline Kurinui & 2220 & $0.32 \%$ \\
\hline Kurinui & 2360 & $0.086 \%$ \\
\hline Moeraki & 2500 & $0.25 \%$ \\
\hline Moeraki & 2510 & $0.40 \%$ \\
\hline Moeraki & 2530 & $0.25 \%$
\end{tabular}

Table 4.5: Clipper Sub-Basin: Dannevirke Series Rock Pyrolysis sample selection.

Washed cutting samples are expressed in metres below rotary table (mbrt). No cutting samples were available between $2157 \mathrm{~m}$ to $2172 \mathrm{~m}$ where total gas ranged between $2 \%$ and $2.71 \%$.

\subsection{Open Hole Wireline Logs}

Openhole wireline logs run in the four exploration wells drilled in the Canterbury Basin include; 1) gamma ray; 2) resistivity; 3) spontaneous potential; 4) neutron and density; 5) sonic; and 6) engineering tools. These logs are discussed briefly below and in (Table 4.6).

\begin{tabular}{|c|c|c|c|c|}
\hline & 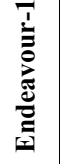 & 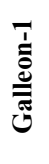 & & Ü \\
\hline \multicolumn{5}{|l|}{ Wireline Log: } \\
\hline \multicolumn{5}{|l|}{ Engineering } \\
\hline BIT & & & & $\mathrm{Y}$ \\
\hline CLI & $\mathrm{Y}$ & $\mathrm{Y}$ & $\mathrm{Y}$ & \\
\hline CLD & & & $\mathrm{Y}$ & \\
\hline CAL1 & & & & $\mathrm{Y}$ \\
\hline CAL2 & & & & $\mathrm{Y}$ \\
\hline TNS & & & & $\mathrm{Y}$ \\
\hline $\mathrm{CDF}$ & & & & $\mathrm{Y}$ \\
\hline \multicolumn{5}{|l|}{ Sonic } \\
\hline LSS & & $\mathrm{Y}$ & $\mathrm{Y}$ & \\
\hline $\mathrm{BHC}$ & $\mathrm{Y}$ & $\mathrm{Y}$ & $\mathrm{Y}$ & \\
\hline DRH & & & & $\mathrm{Y}$ \\
\hline DTC & & & & $\mathrm{Y}$ \\
\hline DTSU & & & & $\mathrm{Y}$ \\
\hline \multicolumn{5}{|l|}{ Natural Radioactivity } \\
\hline GRL & & $\mathrm{Y}$ & & \\
\hline GRD & & $\mathrm{Y}$ & & \\
\hline GRA & & & & $\mathrm{Y}$ \\
\hline GRI & $\mathrm{Y}$ & $\mathrm{Y}$ & $\mathrm{Y}$ & $\mathrm{Y}$ \\
\hline GRS & & & & $\mathrm{Y}$ \\
\hline \multicolumn{5}{|l|}{ Resistivity } \\
\hline $16 \mathrm{~N}$ & $\mathrm{Y}$ & & & \\
\hline ILD & $\mathrm{Y}$ & $\mathrm{Y}$ & $\mathrm{Y}$ & \\
\hline LLD & & $\mathrm{Y}$ & & \\
\hline SFL & & $\mathrm{Y}$ & $\mathrm{Y}$ & \\
\hline ILM & & $\mathrm{Y}$ & $\mathrm{Y}$ & \\
\hline LLS & & $\mathrm{Y}$ & & \\
\hline MSF & & $\mathrm{Y}$ & & \\
\hline LP16 & & & & $\mathrm{Y}$ \\
\hline LP22 & & & & $\mathrm{Y}$ \\
\hline
\end{tabular}




\begin{tabular}{|c|c|c|c|c|}
\hline & LP28 & & & $\mathrm{Y}$ \\
\hline & LP34 & & & $\mathrm{Y}$ \\
\hline & LP40 & & & $\mathrm{Y}$ \\
\hline \multicolumn{5}{|c|}{ Density/Porosity } \\
\hline & PEF & & $\mathrm{Y}$ & $\mathrm{Y}$ \\
\hline & FDC & $\mathrm{Y}$ & $\mathrm{Y}$ & $\mathrm{Y}$ \\
\hline & TNPH & & & $\mathrm{Y}$ \\
\hline & $\mathrm{CNL}$ & & $\mathrm{Y}$ & \\
\hline \multicolumn{5}{|l|}{ Imaging } \\
\hline & FMI & & & $\mathrm{Y}$ \\
\hline
\end{tabular}

Table 4.6: Clipper Sub-Basin: Dannevirke Series wireline logs run.

Full abbreviations are located in Appendix B: Wireline Abbreviations.

\section{Gamma ray measurements}

Naturally occurring radioactivity emanates from uranium, thorium and potassium contained in sediments. The gamma ray log measures the radioactivity of the three elements combined, while a specialised gamma ray $\log$ called the spectral gamma ray log measures individual elements. Gamma is the most useful wireline log for distinguishing between shale rock and non-shale rock. However, a low gamma signature for shale rock can also be recorded where thorium and potassium are relatively low compared to the uranium content. Shale typically emits more gamma rays than other sedimentary rocks due to an increased concentration of radioactive potassium contained within the clay particles and can usefully discriminate shale rocks from others (e.g. sandstone and conglomerate). The accepted unit for radioactivity is the API (American Petroleum Institute) unit. An important derivative of a gamma tool measurement, used in petrophysical calculations, is the calculation of Volume Shale (V-Shale) (Rider, 2002).

Calculation of the V-Shale fraction using a gamma log is particularly useful for net reservoir identification and permeability modelling. The environmentally corrected gamma log will normalise the gamma ray for the effects of borehole size and mud weights, and in general, is the best gamma log to use for the V-Shale calculations. No environmental corrections are applied to any of the GR logs during the V-Shale calculations (Rider, 2002). The most useful form of V-Shale calculation is given by:

Equation 4.4: Gamma Log V-Shale Calculation.

$$
V \operatorname{sh} G R=(G R-G R \min ) /(G R \max -G R \min )
$$

Where GRmin is the average gamma ray value through the 'cleanest' reservoir interval ( $0 \%$ shale), GRmax is the average gamma ray value through the 'shaliest' non-reservoir interval (100\% shale).

Although this explanation of V-Shale refers to the gamma log, it is necessary to briefly discuss other methods of V-Shale calculation such as density-neutron porosity differences which maybe more desirable to use, particularly in shalely sands. These are discussed hereafter under the density-neutron log subheading. 


\section{Resistivity}

Most rock materials are natural insulators, while their enclosed fluids are conductors. Resistivity tools measure the resistance to the passage of an electric current emitted from a wireline tool. If a formation is porous and contains brine water (e.g. sandstone) the recorded resistivity will be low. If the same formation contained hydrocarbon the resistivity will be very high. The resistivity tool is run in open holes where electrically conductive drilling mud or water has been used. Different tools are used to understand the true bore hole resistivity which is affected by mud filtrate build up on the hole wall. These tools can record resistivity properties up to 30 " $(0.762 \mathrm{~m})$ laterally into the formation (e.g. various laterlogs and spherically focused tools). The accepted unit of measurement is the Ohm and is expressed as ohms $\mathrm{m}^{2} / \mathrm{m}$.

\section{Spontaneous Potential}

Self potential (SP) differences between an electrode in the bore hole and a reference electrode at the surface are measured using the SP log. Electrical disequilibrium is created by connecting formations vertically when in nature they are isolated (Rider, 2002). The conductive fluid in the bore hole, a poroperm contrast and a salinity or pressure difference between the bore hole fluid and the formation fluid provoke a SP current. No artificial currents are applied and the accepted unit of measurement is the millivolt (MV). Although the signature or shape of this log will be similar to the gamma log, it lacks bed boundary resolution.

\section{Density and Neutron}

The bulk density of a rock is a function of the density of minerals comprising the matrix and the volume of free fluids which it encloses. The density log measures the differences in lithology type associated with varied bulk density. Medium to high energy focused gamma rays are bombarded at the formation and the attenuation between the tool source and the detectors is measured. Sandstone with no porosity will have a bulk density of $2.65 \mathrm{~g} / \mathrm{cm}^{3}$ the density of pure quartz (Rider, 2002). If this sandstone has $10 \%$ porosity, the bulk density will reduce to $2.49 \mathrm{~g} / \mathrm{cm}^{3}$. This $\log$ is measured as $\mathrm{g} / \mathrm{cm}^{3}$ and is used to calculate formation porosity and hydrocarbon density. It is used in conjunction with the neutron log and is expressed as $\mathrm{gm} / \mathrm{cc}^{3}$.

The neutron log measures the formations reaction to fast neutron bombardment. Neutrons are modified rapidly when they contain abundant hydrogen nuclei, in the geological context; formation water. The log is principally a measure of the formations water content, bound or free. The recognised unit of measurement is the neutron porosity unit (expressed as a \%) which is inherently related to the formations hydrogen index (HI). Density and neutron logs are typically illustrated on the same track but at opposing scales; therefore low density, high porosity signatures are of interest. 
As discussed previously, the density-neutron log maybe used in the calculation of V-Shale. This formula may underestimate the shale fraction in gas-bearing formations and overestimate the shale fraction in poorly compacted formations. Density-neutron analyses are different from the others as two log curves are utilised in the calculations. In some situations (notably shaley sands) this method can yield better results, but is extremely sensitive to bad borehole conditions and should not be used in complex lithologies.

The most useful equation for V-Shale using density and neutron logs is given by:

Equation 4.5: Density-Neutron Log V-Shale Calculation.

$$
V s h N D=(\emptyset N P H I-\emptyset D E N) /(2.0 \emptyset D E N)
$$

Where; $\varnothing_{\mathrm{NPHI}}$ is the lithology corrected neutron porosity, $\varnothing_{\mathrm{DEN}}$ is the density porosity.

\section{Acoustic}

The formation's ability to transmit sound energy is a function of lithology, rock texture and in particular, porosity. The acoustic log measures the formation's interval transit travel time, either as a compressional, shear or stoneley wave form. This log is sensitive to subtle textural variations in both sand and shale and is used to aid in seismic interpretation and to evaluate porosity in liquid filled holes. The recognised unit of measurement is $\Delta \mathrm{t}$ and (expressed in $\mathrm{ft} / \mathrm{sec}$ ) which is the reciprocal of velocity.

\section{Calliper and Engineering}

These are a series of logs run in conjunction with other wireline tools such as resistivity, neutron and gamma runs. Measurements such as the shape of the borehole, weight on bit, mud pressure, formation pressure and temperature can be made. These readings maybe symptomatic of changes in lithology; sandy or brittle facies will cause washout in the borehole while excessive weight on the bit would indicate harder or denser lithology such as limestone. Spiky signatures can partly explain a noisy gamma or resistivity reading where laminations and bedding features could distort track quality. Developments in drilling technology have mitigated avoidable deficiencies in the borehole environment. Non-reactive drilling mud, controlled pump pressure and weight on bit have improved contemporary well quality. This improvement is noticeable when considering older wells such as Endeavour-1; Clipper-1; Galleon-1 which differ in borehole completion quality relative to Cutter-1.

\section{Formation Gas Analysis}

A gas chromatograph (GC) is used to measure the chemical constituents present in complex formation gas samples during drilling operations. As drilling fluids circulate and cutting samples are retrieved from the shakers onboard the drilling rig, the gas chromatograph detects through a narrow tube known as the column, the different chemical constituents present in the carrier gas (cutting samples). The different 
chemical constituents of the sample pass through a gas stream (carrier gas, mobile phase) at different rates. This depends on varying chemical and physical properties and their interaction with the specific column filling; called the stationary phase. The function of the stationary phase in the column is to separate different gaseous components, causing each one to exit the column at a different time (retention time). Other parameters that can be used to alter the order or time of retention are the carrier gas flow rate, and the temperature.

In a $\mathrm{GC}$ analysis, a known volume of gaseous or liquid analyte is injected into the "entrance" (head) of the column, usually using a microsyringe (or, solid phase microextraction fibbers, or a gas source switching system). As the carrier gas sweeps the analyte molecules through the column, this motion is inhibited by the absorption of the analyte molecules either onto the column walls or onto packing materials in the column. The rate at which the molecules progress along the column depends on the strength of absorption, which in turn depends on the type of molecule and on the stationary phase materials. Since each type of molecule has a different rate of progression, the various components of the analyte mixture are separated as they progress along the column and reach the end of the column at different times (retention time). A detector is used to monitor the outlet stream from the column; thus, the time at which each component reaches the outlet and the amount of that component can be determined. Generally, substances are identified (qualitatively) by the order in which they emerge (elute) from the column and by the retention time of the analyte in the column.

The integrity of gas chromatograph analysis, particularly in older wells drilled in the Clipper Sub-Basin is affected by trip gas readings. Trip gas is formation gas that that enters the wellbore when the mud pump is shut down and drill string is being pulled from the wellbore. Gas may enter the bore because of the reduction in bottom hole pressure experienced when the pump is shut down or during swabbing. This necessary procedure can lead to spikes in the chromatograph record which should be recognised and accounted for as drilling induced artefacts and not natural occurrences.

\subsection{Fullbore Formation MicroImaging Logs}

The Fullbore Formation MicroImager (FMI) wireline tool is a 4 arm, pad-based resistivity measurement device with 2 pads on each arm which are in contact with the borehole wall. Each pad has 24 microresistivity buttons. Planar features such as fractures and bedding planes appears as sinusoids when 'unwrapped' (Figure 4.2). The amplitude of the sinusoid is proportional to the dip magnitude of the feature and the lower most point of the curve provides the azimuth. 


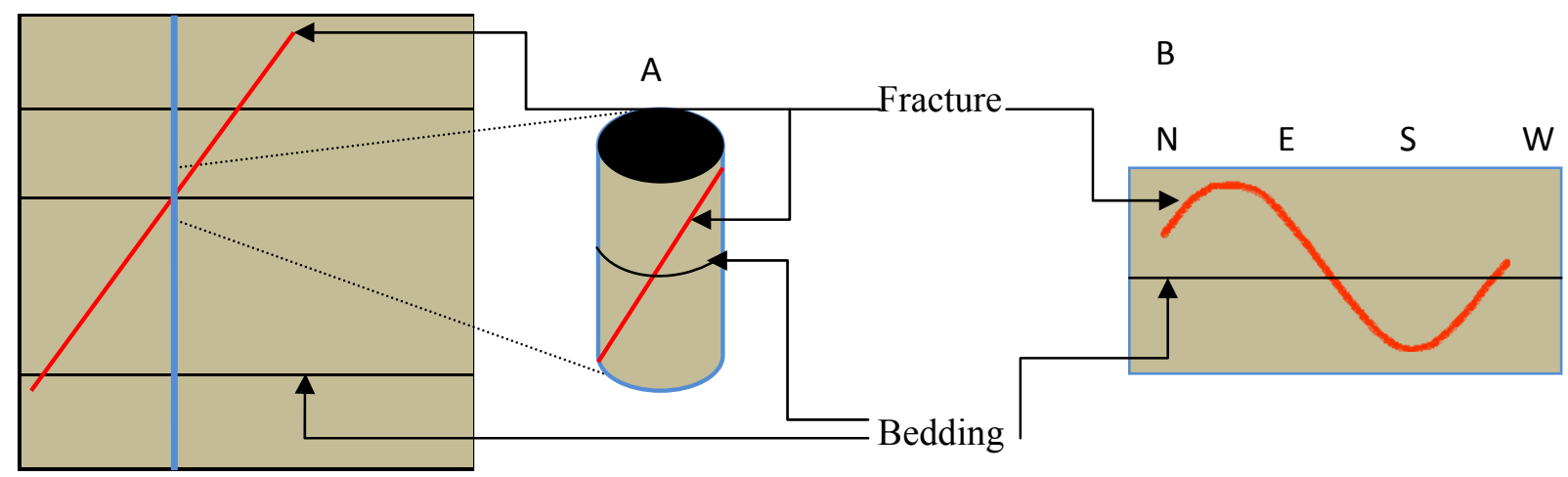

Figure 4.2: Schematic theory underlying fracture sinusoids.

Diagram A represents a vertical borehole with one high angle fracture (red) and horizontal bedding (black). Diagram B is the same image 'unwrapped' relative to north, where the amplitude of the unwrapped fracture sinusoid is a product of the angle it was intercepted in the borehole. The bedding plane in this instance remains horizontal. The azimuth is given by the lowest point on the sinusoid (in this case $180^{\circ}$ south).

The acquired data was processed and interpreted using Petris Recall Version 5.3 software, made available at GNS Science (Figure 4.4). Interpretation was confined to Dannevirke Series mudstones, namely the Kurinui, Moeraki and upper Katiki formations between 2050 and 2600 mbrt in the Cutter-1 well. Processing steps are summarised below:

1. Data was loaded via translation from raw DLIS format into the Recall database.

2. Log quality control (LQC) of raw data was undertaken to assess suitability of the raw data for processing. This involved depth-based plots of acquisition information and cross-plots of borehole calliper and orientation information.

3. The image Preprocess module standardised the raw curves ready for use in Recall for subsequent processing.

4. An accelerometer speed correction was applied to the raw data in an attempt to remove as many speed irregularities from the image as possible.

5. Statically-normalised images were generated by mapping the formation resistivity curves to a colour range in which the data population for the entire imaged interval is covered (Rider, 2002). Essentially, a statically-normalised image illustrates gross resistivity variations throughout the imaged interval.

6. The data was then normalised again using a sliding window of $1.0 \mathrm{~m}$ to generate the dynamicallynormalised image. The dynamically-normalised image highlights the detail.

7. All images were displayed as unwrapped boreholes with $0^{\circ}(\mathrm{N})$ at the left-hand edge, $180^{\circ}(\mathrm{S})$ in the centre and $360^{\circ}(\mathrm{N})$ at the right-hand edge.

Dips were calculated by manually matching sinusoids to observed geological features on the images and were only picked if features could be confidently identified (e.g. bedding planes, drilling induced and natural fractures). Dip types are defined in (Table 4.7). Specific analyses were undertaken as follows: 
1. Sediments that had been originally deposited horizontally (mudstones) were used to determine structural dip and sub-divide the imaged interval into structural zones.

2. Fractures were characterised on the basis of their image morphology, distribution, and orientation. In this case they were further divided based on aperture infilling; either conductive or resistive. A water based drilling mud (KCL/Polymer) was used in the Cutter-1 well; conductive fractures therefore appear dark while resistive fractures appear bright.

\begin{tabular}{|c|c|c|c|}
\hline Dip Type & Definition & Tadpol & \\
\hline Mudstone Bedding & $\begin{array}{l}\text { Planar bedding features occurring within units identified as } \\
\text { mudstones. GR usually } \geq 100 \text { GAPI. }\end{array}$ & Green & \\
\hline Resistive Fracture & $\begin{array}{l}\text { Planar, bright (resistive), high angle }\left(>40^{\circ}\right) \text {, discordant features that } \\
\text { can be traced discontinuously to continuously to around the } \\
\text { borehole. }\end{array}$ & Yellow & \\
\hline Conductive Fracture & $\begin{array}{l}\text { Planar, dark (conductive), high angle }\left(>40^{\circ}\right) \text {, discordant features } \\
\text { that can be traced discontinuously to continuously to around the } \\
\text { borehole. }\end{array}$ & Brown & \\
\hline Tensile Fractures & $\begin{array}{l}\text { Drilling-induced tension fractures (DITF) that appear as thin, dark, } \\
\text { vertical to sub-vertical, or "J" to "S" shaped features, } 180^{\circ} \text { apart and } \\
\text { orthogonal to borehole breakouts. }\end{array}$ & Purple & \\
\hline Borehole breakout & $\begin{array}{l}\text { Borehole breakout features that appear as thick, dark, vertical, } \\
\text { locally irregular features that occur } 180^{\circ} \text { apart and orthogonal to } \\
\text { DITF. }\end{array}$ & Scarlet & \\
\hline
\end{tabular}

Table 4.7: Cutter-1: Dip types and definitions used in FMI interpretation.

Mudstone bedding typically exhibits low angle bedding planes; a product of low energy deposition. Resistive and conductive natural fractures vary in aperture (micro scale) and distribution (metre scale). Fractures are visible due to a resistivity contrast between the fracture and host rock matrix. Fractures may be conductive or resistive depending on fracture fill; drilling fluids, sulphides and mud smear will appear dark in an FMI image, cataclastics and various mineralisation will appear light in an FMI image. 
Breakout or drilling induced tensile fractures (DITF) are only visible as a function of a complex set of interactions that include may include mud weight and rock strength. They provide important information concerning in-situ stress properties of the formation (e.g. $\mathrm{Sh}_{\min }$ and $\mathrm{Sh}_{\max }$ orientations). Figure 4.3 illustrates the difference associated with minimum and maximum stress directions.

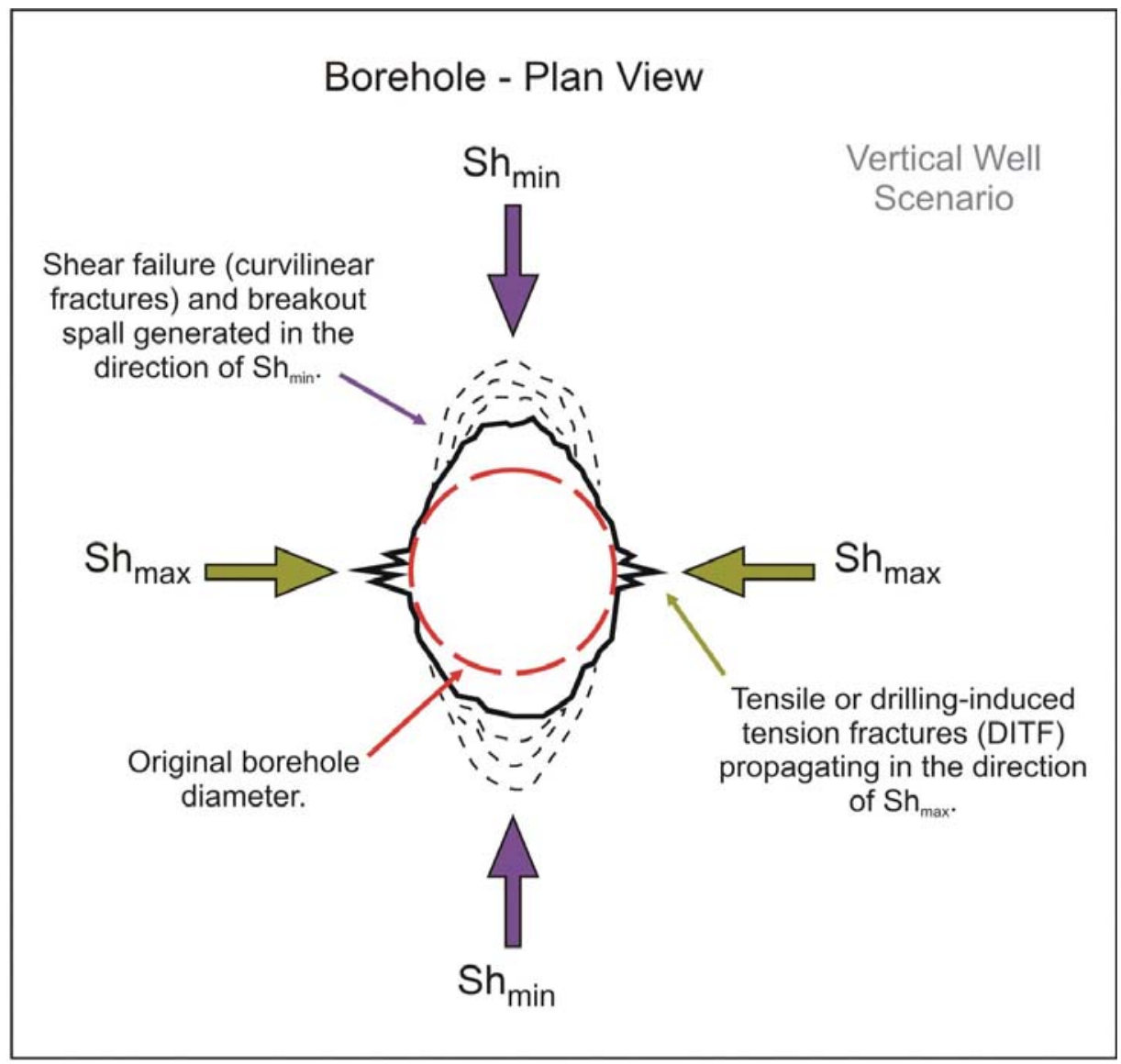

Figure 4.3: Drilling Induced Tensile Fractures (DITF) and shear failure fracture schematic. After (Dart \& Zoback, 1989). 


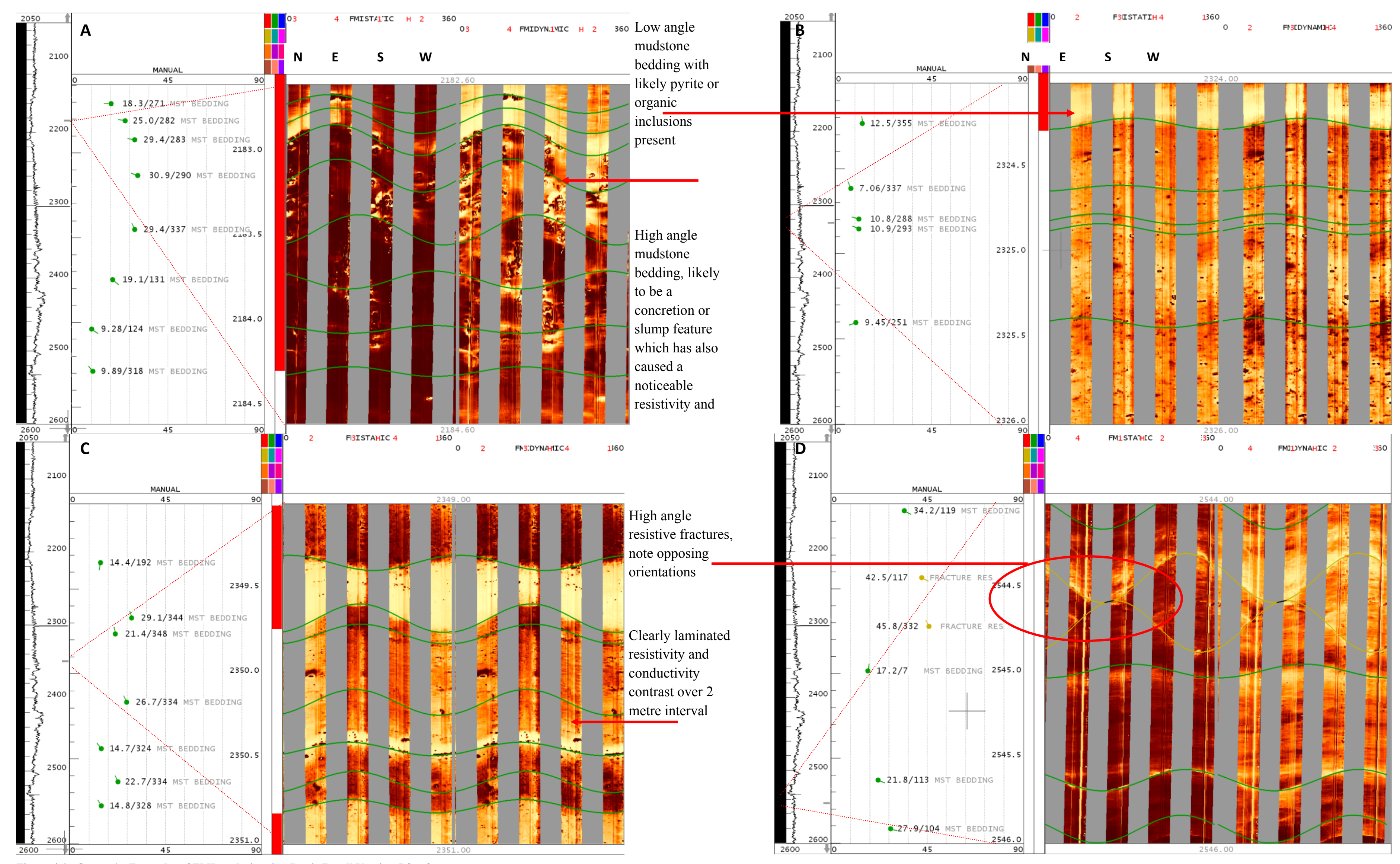

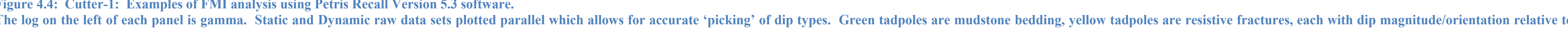
north expressed. Lighter coloured intervals are resistive relative to the darker intervals which are more conductive. Images are becoming progressively deeper from left to right. 


\subsection{Results and Interpretation of Laboratory Based Data}

\subsection{Thin Sections}

Twenty thin sections were examined from four wells (Table 4.1). Of the twenty slides examined, dark brown to orange brown mud matrix supports up to $40 \%$ of identifiable very fine sand sized grains. The detrital grains were very fine grained $(<60 \mu \mathrm{m})$ moderately poorly sorted to poorly sorted, predominantly sub angular to sub rounded in shape with evidence of chemical compaction and pressure solution between the grain contacts. Quartz overgrowths were identified as a minor cement phase, occurring as very thin and partial syntaxial overgrowths typically in intergranular pore space. All samples display a massive to laminated structure in thin section with laminae clearly visible due to alignment of opaque grains.

Detrital quartz is present in all samples (Figure 5.1) of which polycrystalline quartz (average 68\%) exceeds monocrystalline quartz (average 32\%). This is taken to reflect a volcanic influence, perhaps attributed to the underlying basaltic intrusives. According to Mortimer (2007) basaltic intrusives with anomalously young ages of $28.6 \pm 1.2 \mathrm{Ma}$ and $45.8 \pm 1.8 \mathrm{Ma}$ thought to be related to the Deborah and Waiareka Volcanics which are located at the base of the Paleogene record in the Cutter-1 well. Alternatively the polycrystalline nature of the quartz would reflect recycling from schist terrane (as suggested by the rock fragments observed in thin section). 

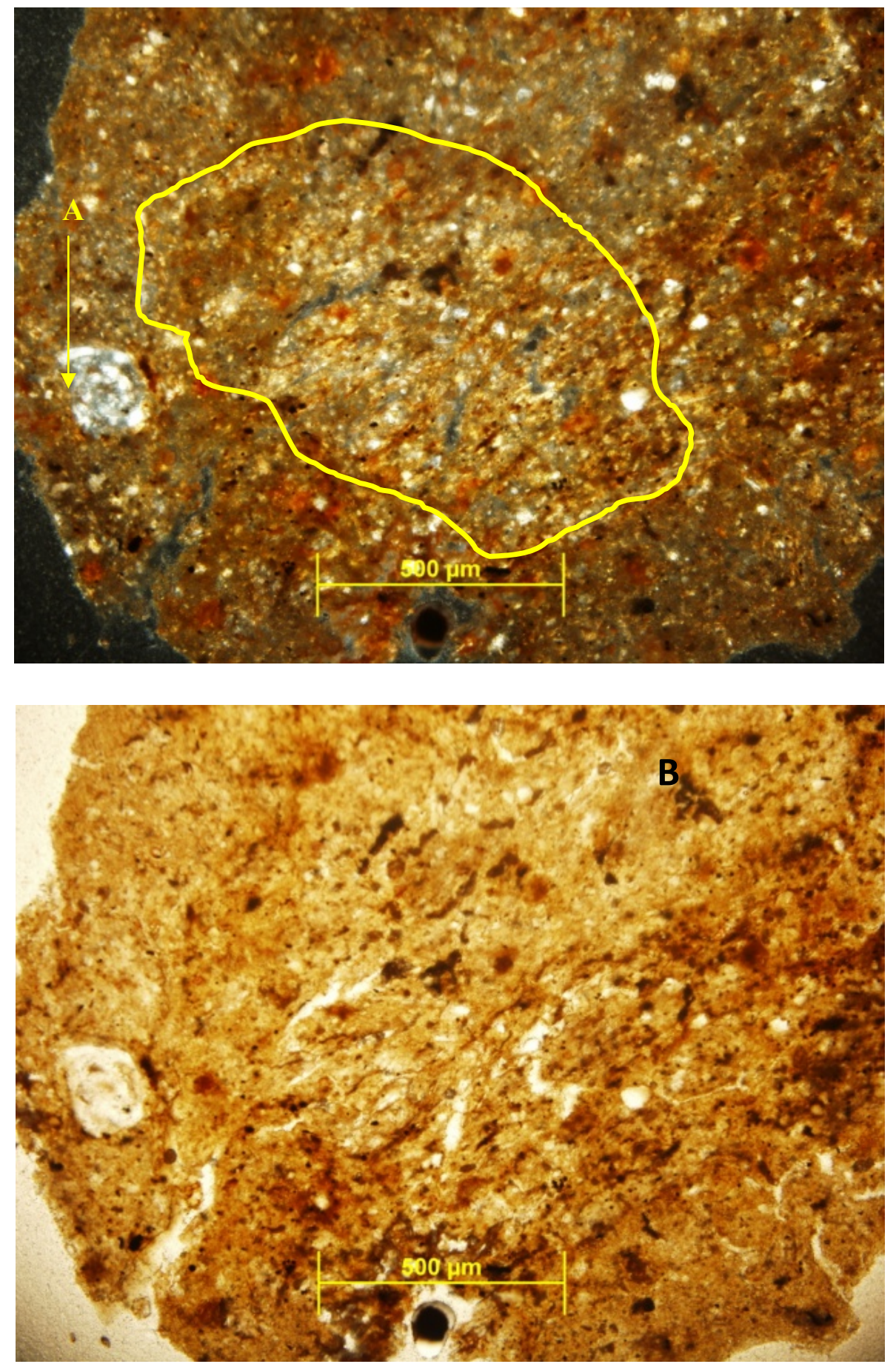

Figure 5.1: Cutter-1: Thin section of cutting sample 2600 mbrt.

Cross polarised light (XPL) top image, Plane polarised light (PPL) image to the bottom. Illustrated is the fine grained matrix and slight preferential fabric (bottom left to top right). Between 15-20\% undulose quartz grains which appear bright in XPL image; these are very fine grained, moderately sorted, sub-angular to sub-rounded. PPL image illustrates no obvious evidence of plagioclase feldspar, but apparent are opaque grains, perhaps pyrite or organic remnants surrounded in calcite matrix. A denotes polycrystalline quartz, B denotes opaque inclusions.

Lithic fragments (Figure 5.2) comprise metamorphic (metamorphic textures are visible) and sandstone grains. It is also possible these fragments could be burrows; created by bioturbidation. Wilson \& McMillan, (1996) and Morgans (2009) identified frequent burrowing and biogenic reworking of Teurian 
to Heretaungan sediment in the onshore record. The poorly sorted nature of the grains within the yellow curve in Figure 5.2 suggest reworking and disturbance which is indicative of ichnofossils
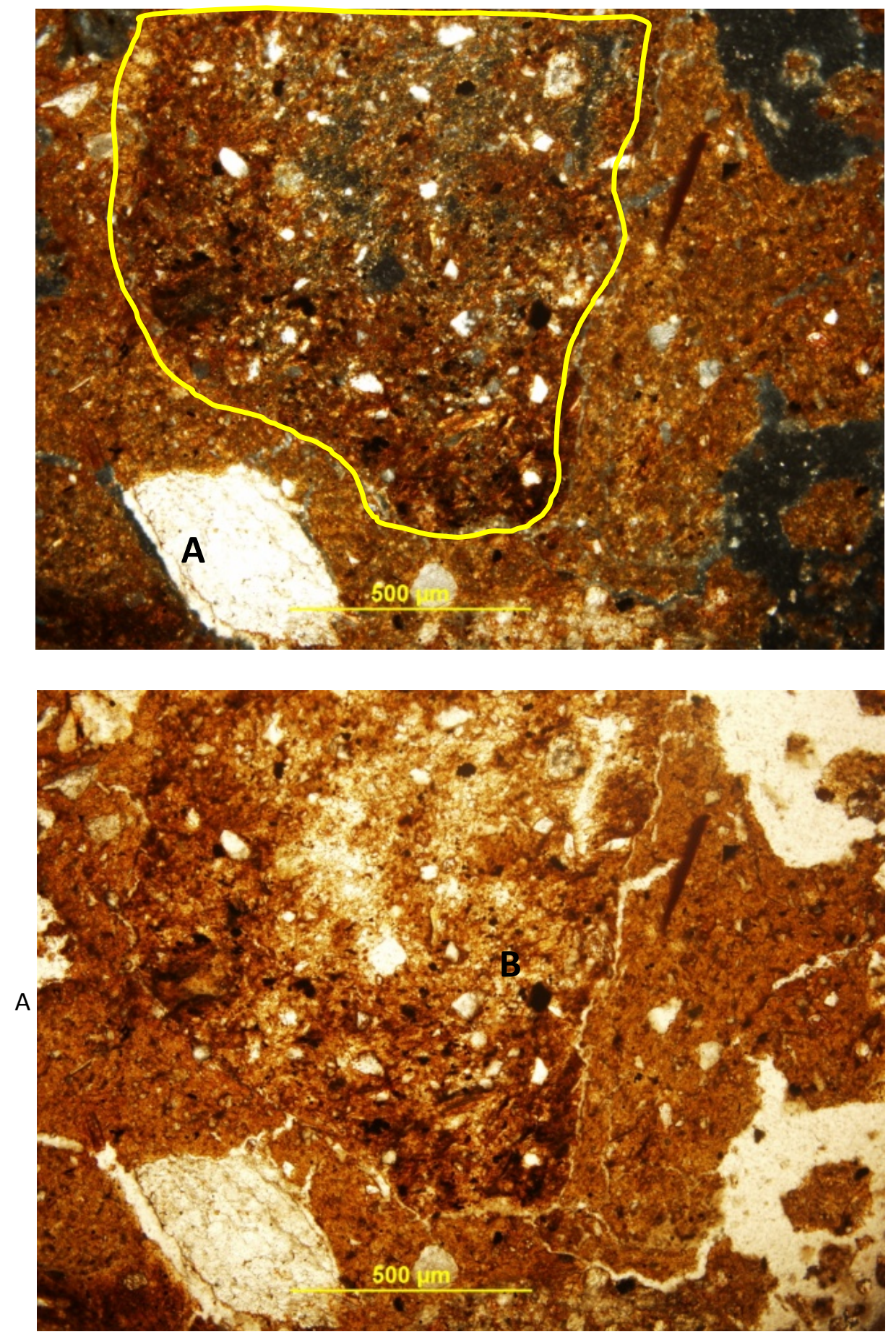

Figure 5.2: Galleon-1: Thin section of cutting sample 2450 mbrt.

Cross polarised light (XPL) top image, Plane polarised light (PPL) image to the bottom. Illustrated is a fine grained predominantly calcite matrix. Up to $10 \%$ very fine grained, sub angular to sub rounded poorly sorted calcite grains which appear dull white in XPL. Between 10-15\% undulose quartz grains which appear bright in XPL image; these are very fine grained, moderately sorted, sub-angular to sub-rounded. PPL image illustrates trace orthoclase feldspar which appear dull yellow. Enclosed in the yellow border is a possible sandstone lithic remnant or burrow. Apparent are opaque grains, perhaps pyrite or possibly organic remnants surrounded in calcite matrix. A denotes monocrystalline calcite, B denotes opaque inclusions. 
Carbonate (micrite) is the main matrix material observed in these mudstones. It is likely the carbonate has replaced the original skeletal grains such as foraminifera. Similarly pyrite observed in all samples occurs as a minor cement phase replacing organic matter. Pyrite was quantified and identified during XRD and SEM analysis respectively and in discussed in Sections 5.2 and 5.3.
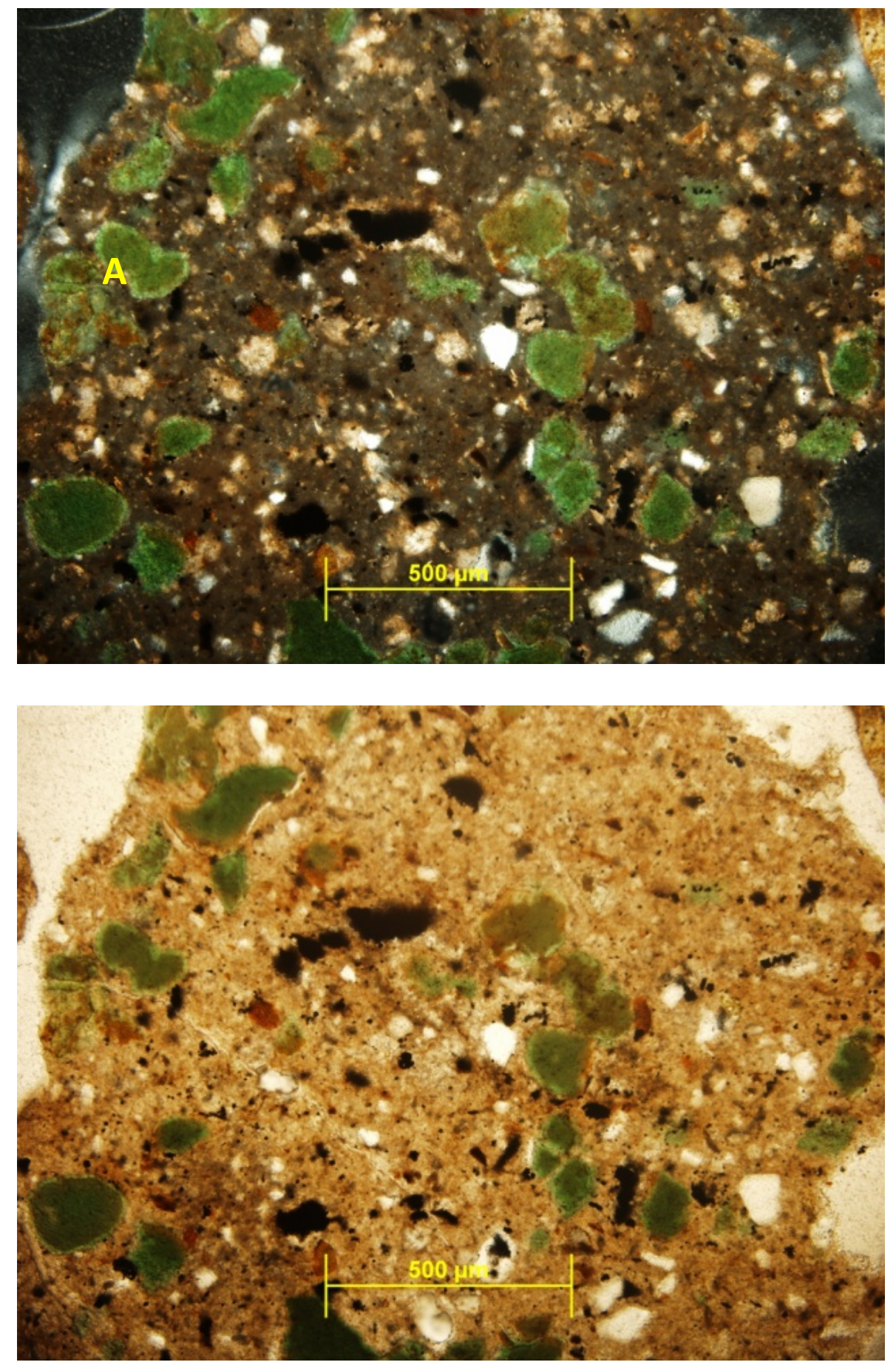

Figure 5.3: Cutter-1: Thin section of cutting sample 2530 mbrt.

Cross polarised light (XPL) top image, Plane polarised light (PPL) image to the bottom. Illustrated is a fine grained predominantly calcite matrix with up to $20 \%$ very fine grained, sub angular to sub rounded poorly sorted calcite grains which appear dull white in XPL. Up to $10 \%$ undulose quartz grains which appear bright in XPL image; these are very fine grained, moderately sorted, sub-angular to sub-rounded. Apparent are well rounded to sub-rounded emerald green 
glauconitic grains and opaque, perhaps pyrite or possibly organic remnants surrounded in calcite matrix. A denotes glauconite.

Localised to the Kurinui - Moeraki formation boundary across all four wells is the presence of coarse sand sized well rounded to sub rounded glauconite grains (Figure 5.3). Glauconite is a green silicate mineral found in sedimentary rocks which is suggestive of slow sedimentation and oxidising environments. Glauconite abundance varies between $5-15 \%$ and the well rounded to sub-rounded appearance suggests the grains have been transported to their current position. Alternatively, the rounded morphology of the glauconite grains could represent infilling and mineral replacement of foraminifera species.

No visible porosity has been observed in this section, but it should be noted that authigenic clay minerals are likely to contain significant volumes of intercrystalline microporosity (Higgs, 2007a).

Using the classification scheme of Folk et al., (1970) the quartz-feldspar-lithic (QFL) composition of the samples examined in this section is illustrated in Figure 5.4. The majority of the samples classify as sublitharenite. 


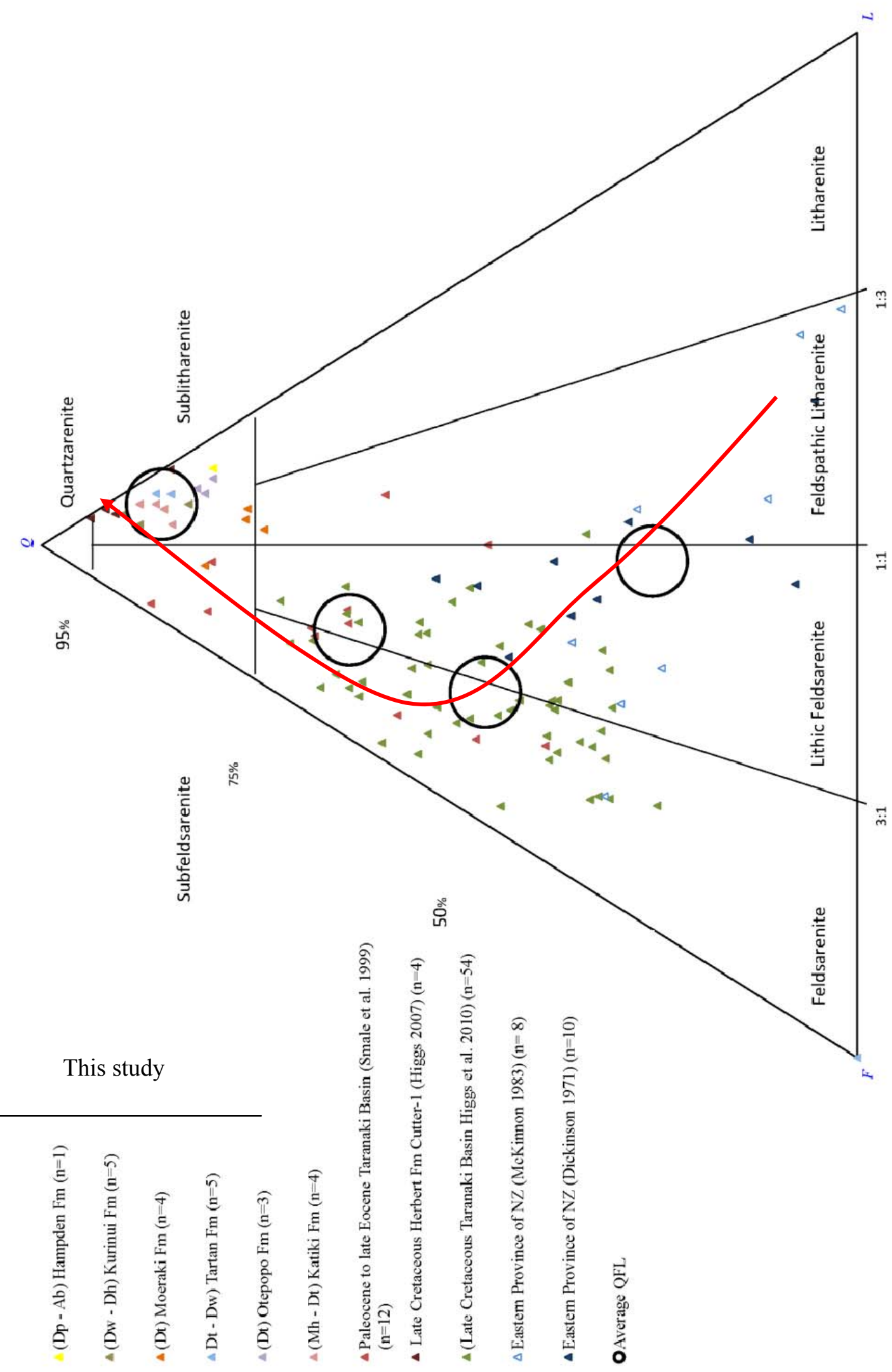

Figure 5.4: New Zealand: Permian to Paleogene Quartz-Feldspar-Lithic Composition Plot.

Imposed red arrowed line denotes a line of best fit through average QFL ratios and (circled) tracks a trend from oldest to youngest petrofacies. 
A petrofacies change is illustrated from Permian to Jurassic rocks (Eastern Province facies of Dickinson 1971 and McKinnon 1983) which constitute feldspathic litharenite to lithic feldsarenite composition of the Torlesse terrane. The average QFL ratio of 19:36:38 of these rocks changes into predominantly feldsarenite sandstones during the Cretaceous, at least in the Taranaki Basin. Sandstones of this age have an average QFL ratio of 31:24:8 (i.e. considerably more quartzose). Tertiary (Kapuni Group) Taranaki Basin rocks display a QFL ratio of 35:15:6 which is slightly more quartzose than Cretaceous Taranaki sediments (Smale et al., 1999). During the Cretaceous in the Canterbury Basin the typical sandstone QFL composition is 58:0.3:6 (Higgs 2007a). In this study, Paleogene sediments have an average QFL of 82:5:13. Relative to the other samples plotted, the Canterbury Basin samples are anomalously rich is quartz and relatively low in feldspar, particularly the Cretaceous sandstone of the Herbert Formation (Higgs, 2007a). The absence of feldspar (orthoclase and plagioclase) from all samples examined is a likely response to chemical weathering and diagenetic changes that took place. In large part the feldspars are clay minerals are thoughts to have been altered to clay minerals of the kaoline group (Retallack, 2001).

Reasons underlying the anomalously high quartz in the Canterbury Basin samples are poorly understood, although derivation from Torlesse basement (as recycled grains) or volcanics is a possibility; these older sediments being partly schistose and exhibiting higher silica values than greywackes of the Western Margin (Dickinson, 1971 and MacKinnon, 1983).

\subsection{X-Ray Diffraction}

Twelve XRD samples were examined from four wells, all displaying highly crystalline mineralogy which is characterised by sharp diffraction patterns. The XRD results suggest a high proportion of quartz is present (up to $72 \mathrm{wt} \%$ ) within the matrix which is very fine sand sized and finer. A pronounced calcite signature is observed, typically occurring between $27^{\circ} 2 \theta$ and $29^{\circ} 2 \theta$ but this is restricted mainly to Endeavour-1 and Cutter-1. Mixed layer clay occurred between $2^{\circ} 2 \theta$ and $20^{\circ} 2 \theta$, whereby kaolinite is the predominate clay mineral forming in these samples, constituting up to 26wt\% (Cutter-1 $2390 \mathrm{mbrt}$ ) followed by subordinate illite and to a lesser extent smectite which ranged in abundance from trace to $16 \mathrm{wt} \%$ respectively. Although illite/smectite weight percentages were calculated in XRD analyses, individual illite and smectite constituents were only recorded in the three samples tested in Endeavour-1 and at 2510mbrt in Cutter-1. Illite weight percentages are greater than that of smectite (and montmorillonite) where ratios varied between $2: 1$ and 4:1. Diffraction patterns where highly crystalline consistently occurring at c.a. $9^{\circ} 2 \theta$.

A maximum calcite value was obtained from Cutter- 1 at 2110 mbrt where $45 \mathrm{wt} \%$ was measured. All diffraction patterns illustrate highly crystalline mineral structures. In particular, the quartz signatures, which compare favourably to those expressed by Jones \& Segnit, (1971), who published a series of 
diffraction curves that ranged from Opal-A to Opal-C. A well ordered crystalline quartz structure will display a spiky response opposed to an amorphous silica specimen which will produce a flat rounded response. Based on these XRD results, no evidence was found to suggest the quartz is amorphous in nature and is assumed to be detrital or a product of silica diagenesis.

Four selected XRD results are presented (Figure 5.5 \& Figure 5.6), whereby each plot illustrates characteristically similar diffraction patterns. Highly crystalline quartz is illustrated in all samples, which were taken from; 1) Hampden Formation, Endeavour-1; 2) Kurinui Formation, Cutter-1; 3) Moeraki Formation, Galleon-1; and 4) the Otepopo Formation in Clipper-1. Commencing between $21^{\circ} 2 \theta$ and becoming less pronounced at c.a. $70^{\circ} 2 \theta$ for any given sample, quartz is the most abundant mineral species identified. The selected sample from Endeavour-1 has the most pronounced baseline of the four samples plotted and displays frequent calcite and kaolinite occurrences. The Clipper-1 sample represents the smallest variation in baseline magnitude and is clay poor.

Clay abundance patterns are also plotted on corresponding graphs, which is the $2 \theta$ scale magnified four times from the original $2 \theta$ plot. This illustrates a consistency between the kaolinite, illite and to a lesser extent the smectite patterns. 

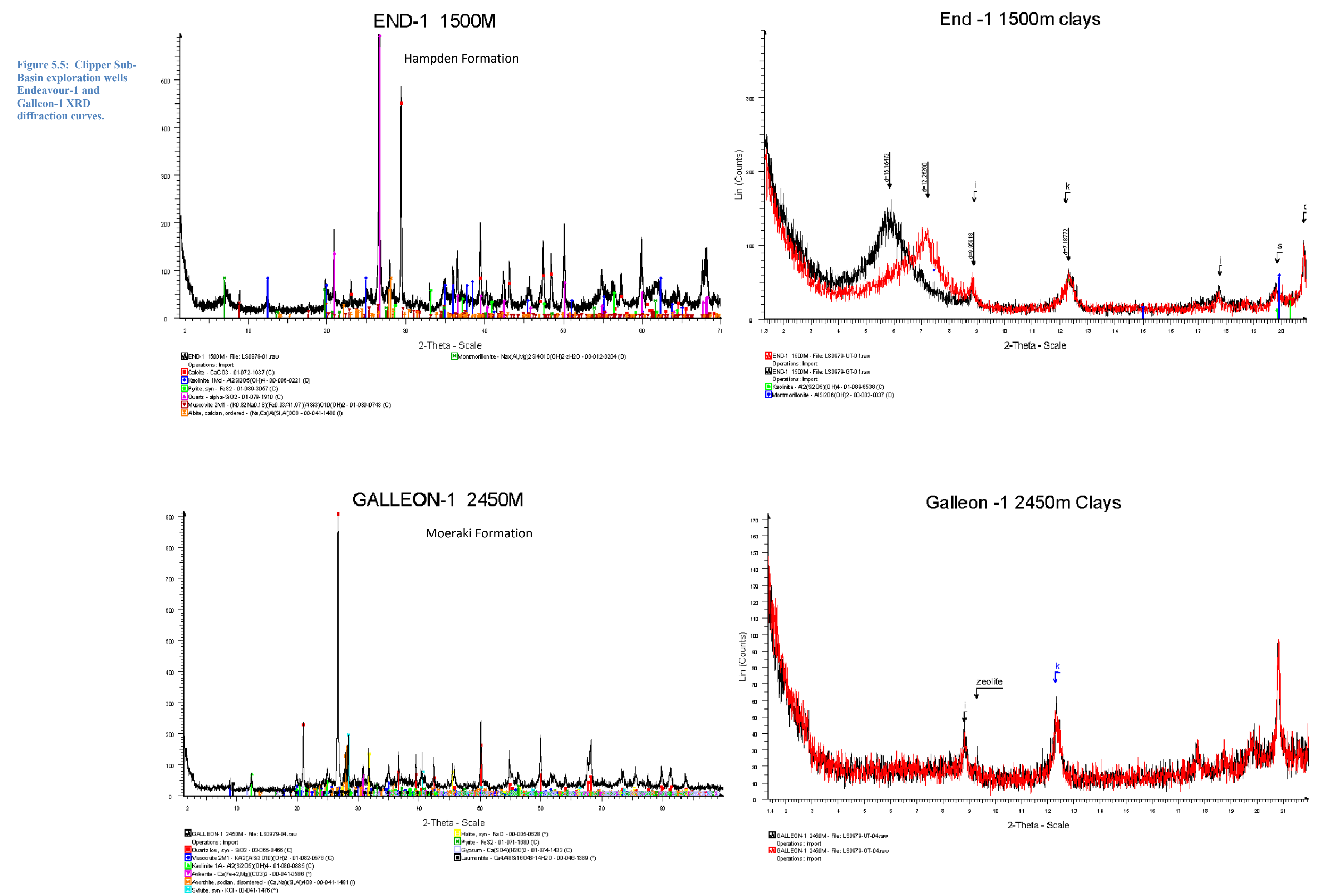

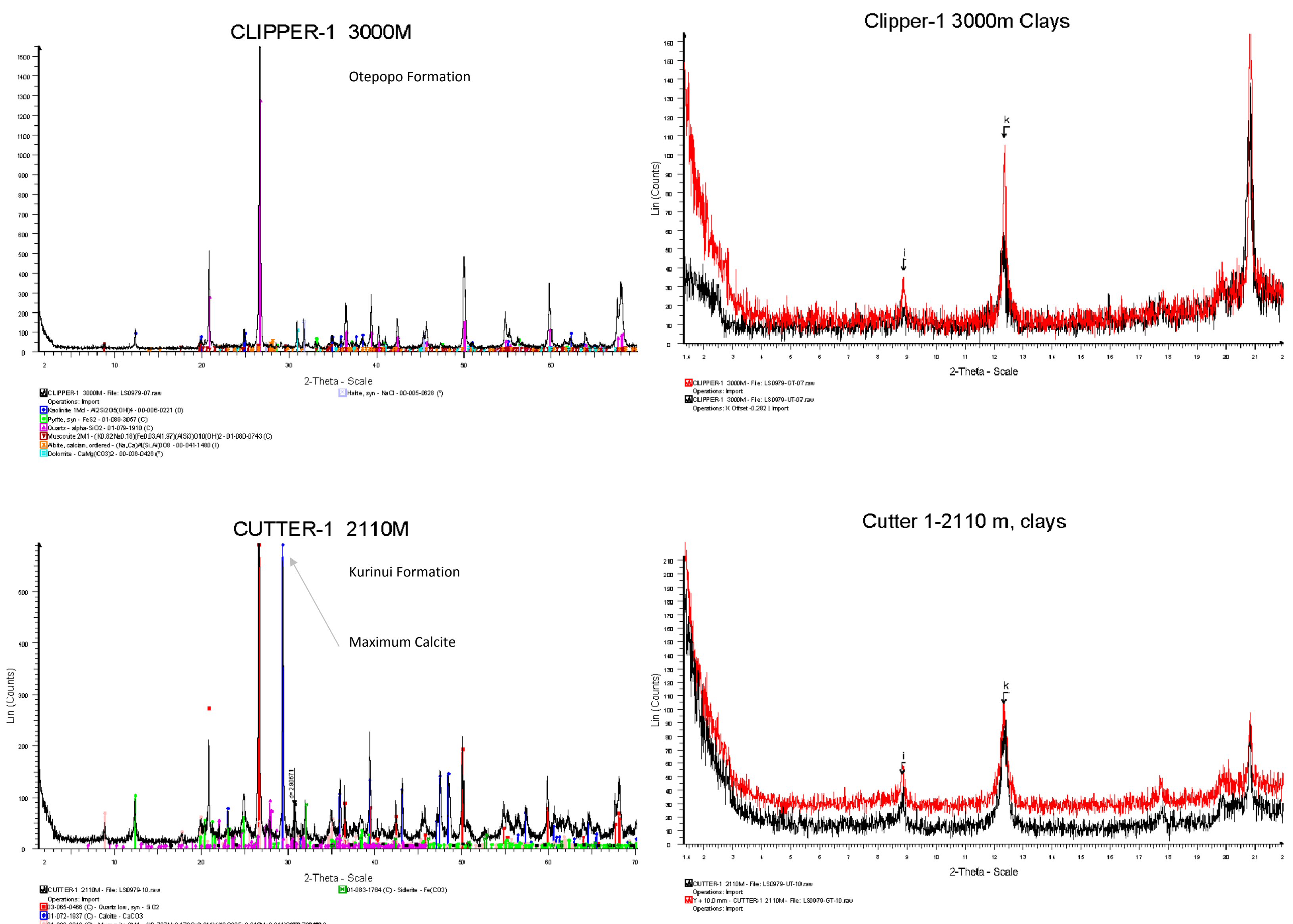

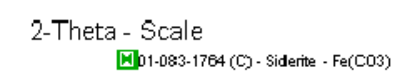

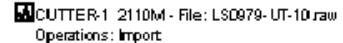

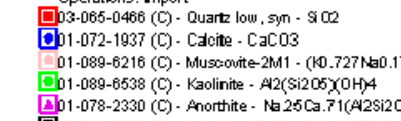


Combining XRD results from this study and from previous work carried out on Cutter-1 samples by Higgs (2007), a wireline and mineralogy relationship is illustrated in Figure 5.7. Elevated quartz corresponds to decreased smectite/illite weight percentage in the two gas-rich intervals identified in Cutter-1. This also corresponds to a decrease in gamma, resistivity, density and acoustic logs. Therefore, it is reasonable to suggest gas is accumulating in intervals of elevated quartz and reduced clay content, presumably where porosity and permeability values are greater.

Compaction of a mudstone during increased burial inevitably leads to mineral dissolution and various precipitation reactions (Bjorlykke \& Hoeg, 1997). According to Peltonen et al., (2009) one of the most common and important chemical reactions in mudstones is the smectite to illite (S-I) transformation. A consequence of this reaction is the formation of significant amounts of silica (Peltonen et al., 2009). As silica is released it is precipitated as quartz cement within the micro-pores of the clay matrix. This may lead to a reduction in gamma (as quartz has little or no natural radioactivity), an increase in density and overpressuring of the formation creating smaller and more rigid crystals which influence mudstone physical properties such as anisotropy and strength (Thyberg et al., 2010). This theory may have validity especially as identified illite is frequently greater in abundance than smectite. However, there is insufficiant data in this thesis to pursue this notion thoroughly, but, a high quartz and a low clay trend in intervals of elevated gas is noted.

If enhanced grain alignment (anisotropy) and quartz crystallisation is occurring in these discreet intervals of elevated silica, it is unclear why the sonic interval time and density logs (in particular) do not reflect a hardening or stiffening of the mudrock; as would be expected with densification. The dissolution of smectite (and opal C) into high silica concentrations relative to quartz saturation in the pore water is well documented (Abercrombie et al., 1994 and Bjorlykke \& Hoeg, 1997). Micro-quartz will not precipitate in sediments lower than a temperature of $60-80^{\circ} \mathrm{C}$ has been reached. However, measured bottom-hole temperatures in Cutter-1; illustrate formation temperatures of c.a. $62-75^{\circ} \mathrm{C}$. This would therefore be well within range for a micro-quartz producing reaction to occur. 


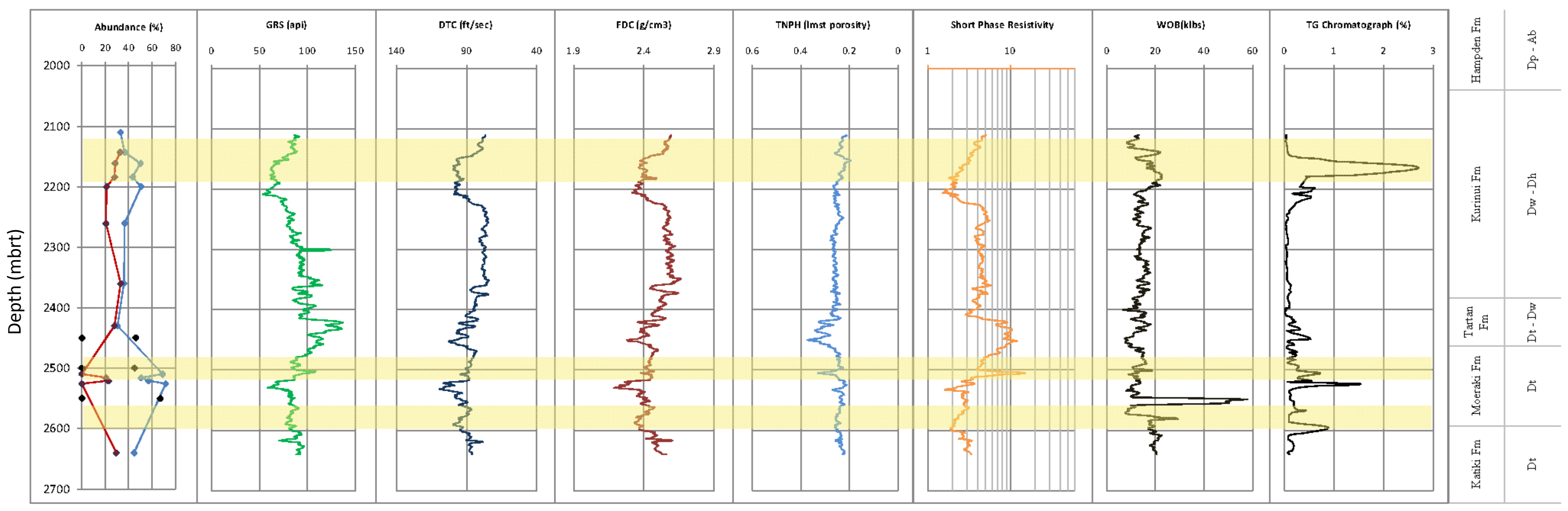

Figure 5.7: Cutter-1: Abundance quartz/mixed layer clay vs. wireline relationship.

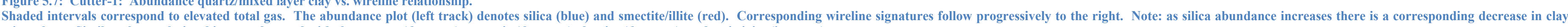
mineralogy. Similar phase relationships are observed with the gamma (decrease), acoustic (decrease), density (decrease), and resistivity (increase). 


\subsection{Scanning Electron Microscopy and Energy Dispersive Spectroscopy}

Twenty samples (which comprised 15 SEM and five EDS analyses), from four wells were examined (Table 4.4 and Appendix F: Scanning Electron Microscopy \& Energy Dispersive Spectroscopy Analysis). Of the twenty samples examined, no biosiliceous grains were identified.

Scanning Electron Microscopy (SEM) and Energy Dispersive Spectroscopy (EDS) illustrate two particular findings;

1. Silica abundance is not biogenic in origin.

2. Micro-quartz (which mainly occurs as sub-micron to approximately $2-25 \mu \mathrm{m}$ in size) is found within the micro-pores of the fine grained clay matrix comprising kaolinite and mixed layer smectite - illite minerals.

A very fine grained quartz cement, in fills the micro-pores of the fine grained clay matrix. Quartz grains are angular to sub-angular and range in size from c.a. $2 \mu \mathrm{m}$ to $65 \mu \mathrm{m}$ in diameter and varied between $10 \%$ and 50\% abundance (Figure 5.8). The matrix is composed of three clay minerals (which correspond to semi quantitative findings presented in Section 5.2). Kaolinite was the most abundant clay mineral observed (Figure 5.9) and is often found with quartz, iron oxides, pyrite, siderite, muscovite and other clay minerals (Retallack, 2001). Subordinate illite and smectite, which are sometimes difficult to distinguish exhibit a webbed or stringy architecture (Figure 5.10), but illite is usually more platey in appearance (Figure 5.11) than smectite. Mixed layer clays are intermediate mineral stages which occur during degradation by weathering and during aggradation by deep diagenesis (Larmer, 1998). Because clay mineral structures are very similar, the crystal lattice structure may be of a chlorite or illite type, which gives rise to the term; mixed layer clay which is subsequently used in the following figures (Figure 5.12).

Pyrite was commonly observed, particularly in the lower Moeraki Formation and Otepopo Formation, representing up to $20 \%$ of the sample (Figure 5.13). They were distinguishable by their isometric crystals that appear as cubes or pyritohedrons (twelve irregular or pentagonal sided faces). 


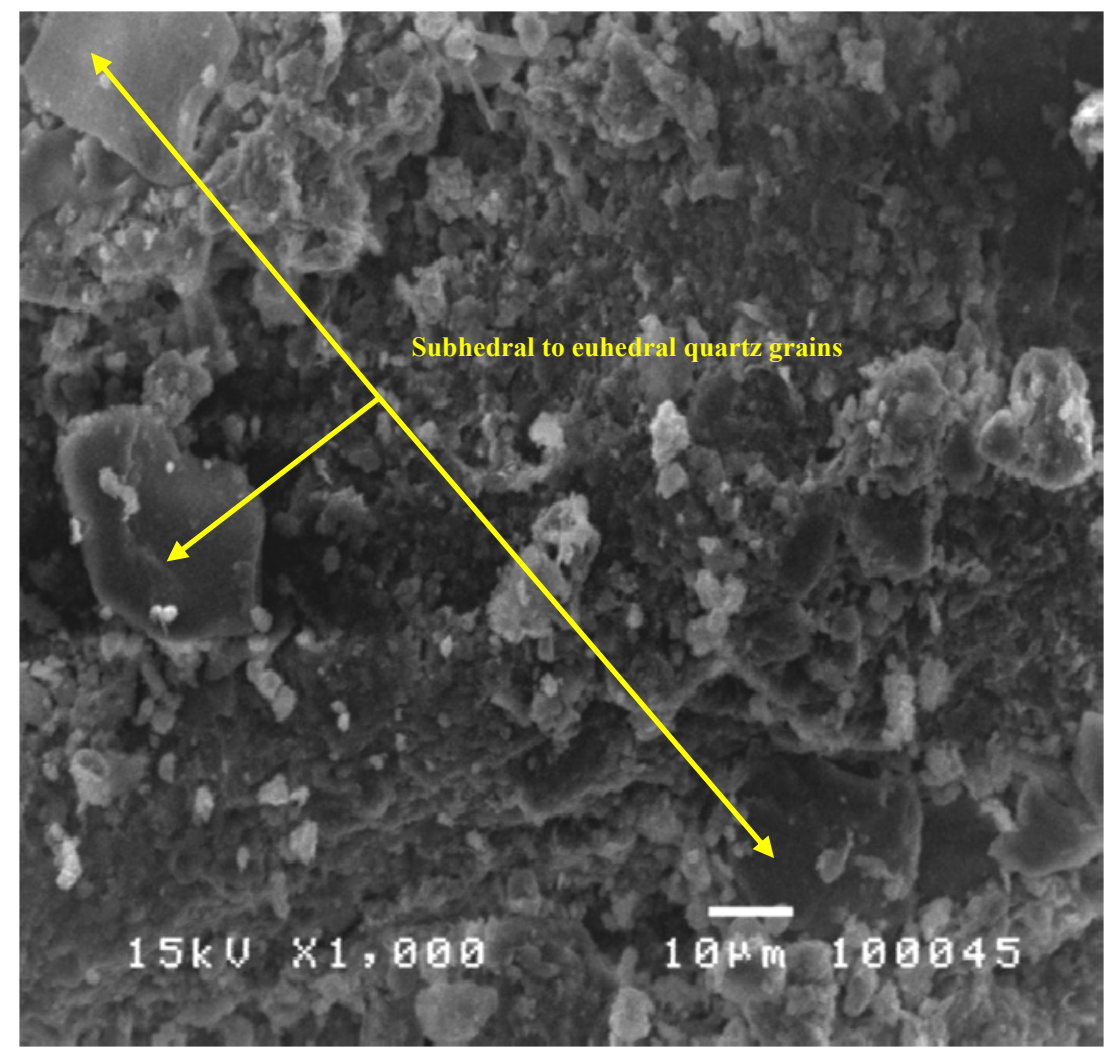

Figure 5.8: Endeavour-1: 1600 mbrt subhedral to euhedral quartz grains determined using EDS

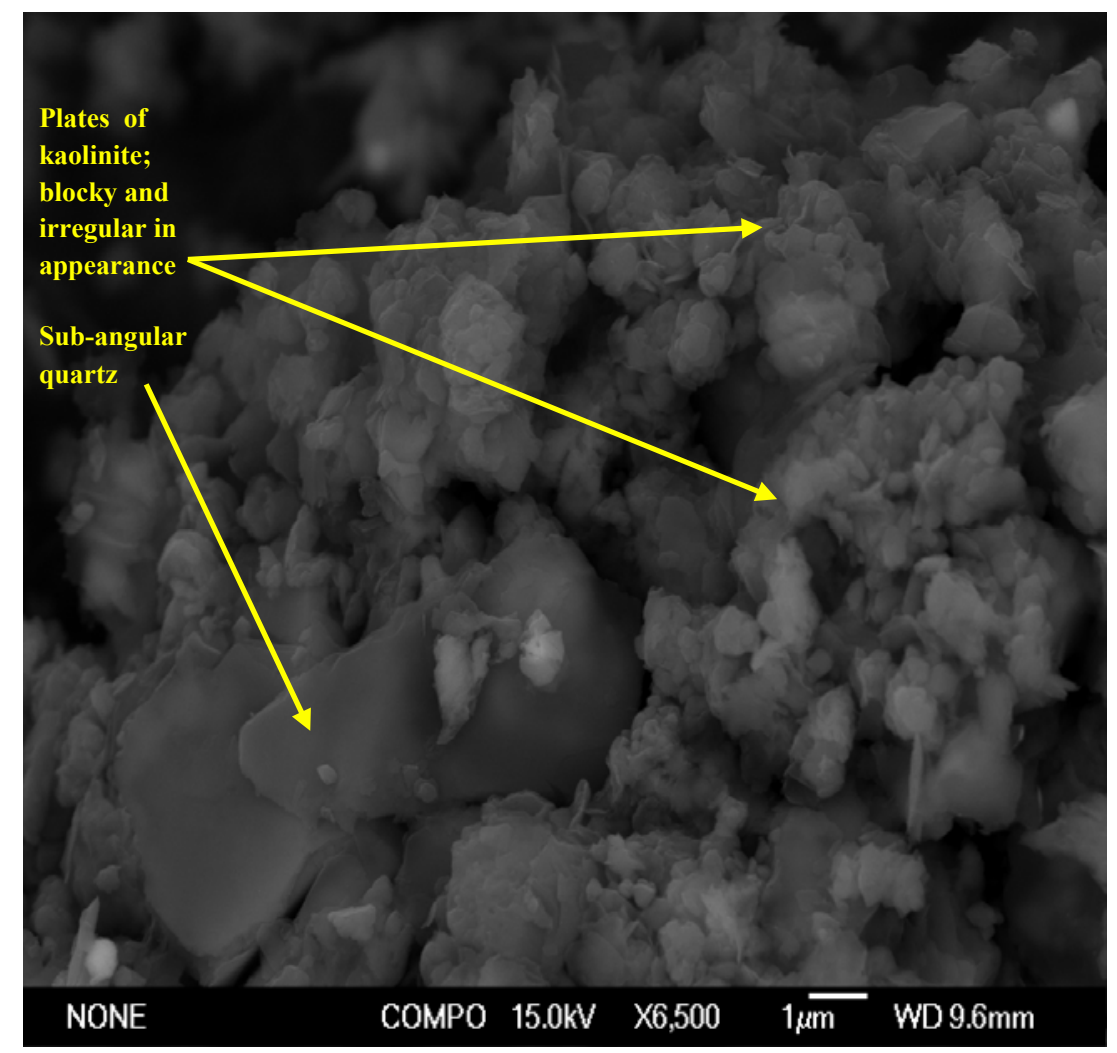

Figure 5.9: Cutter-1: 2430 mbrt plates of kaolinite determined using EDS. 


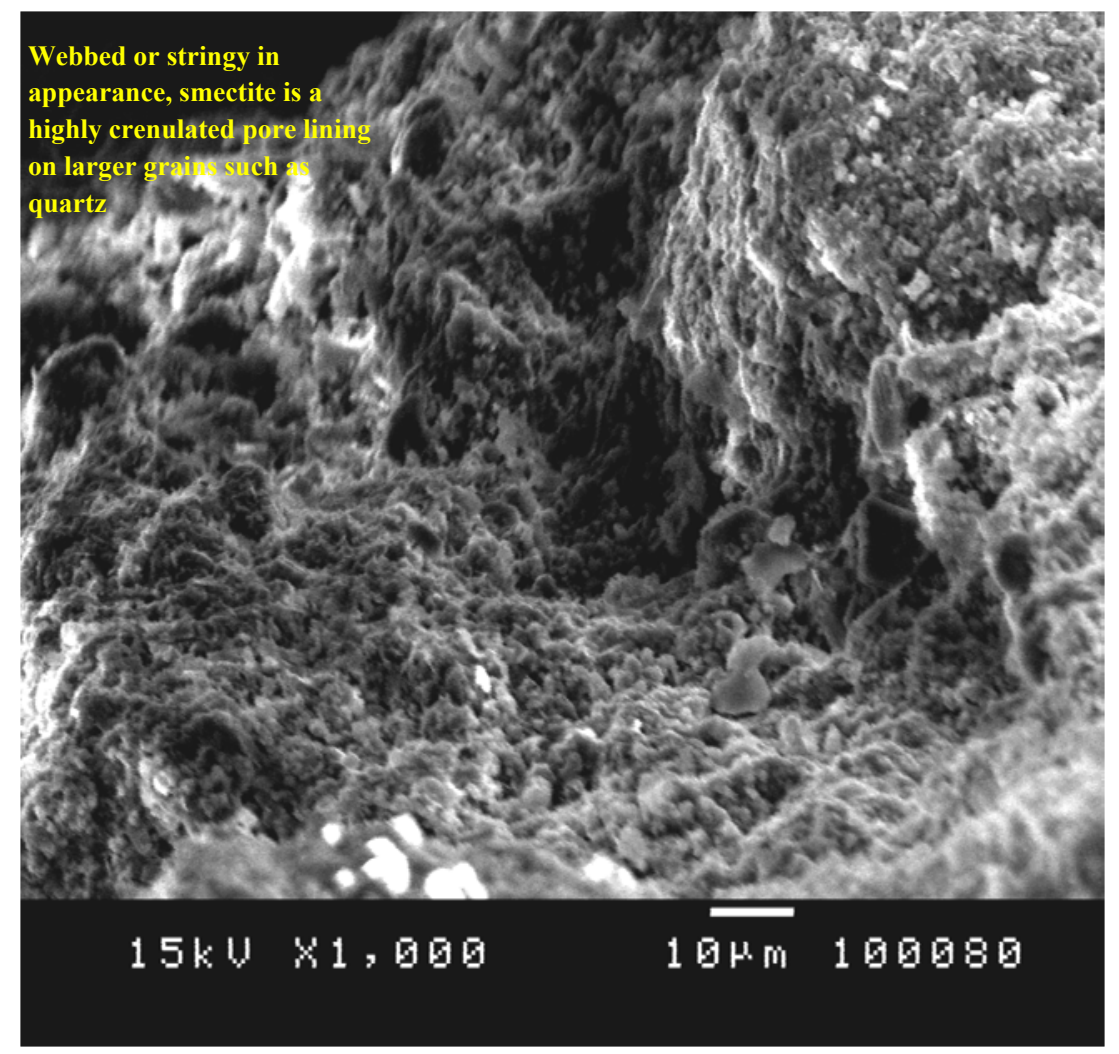

Figure 5.10: Clipper-1: 3000mbrt SEM image illustrating webbed or stringing smectite and illite.

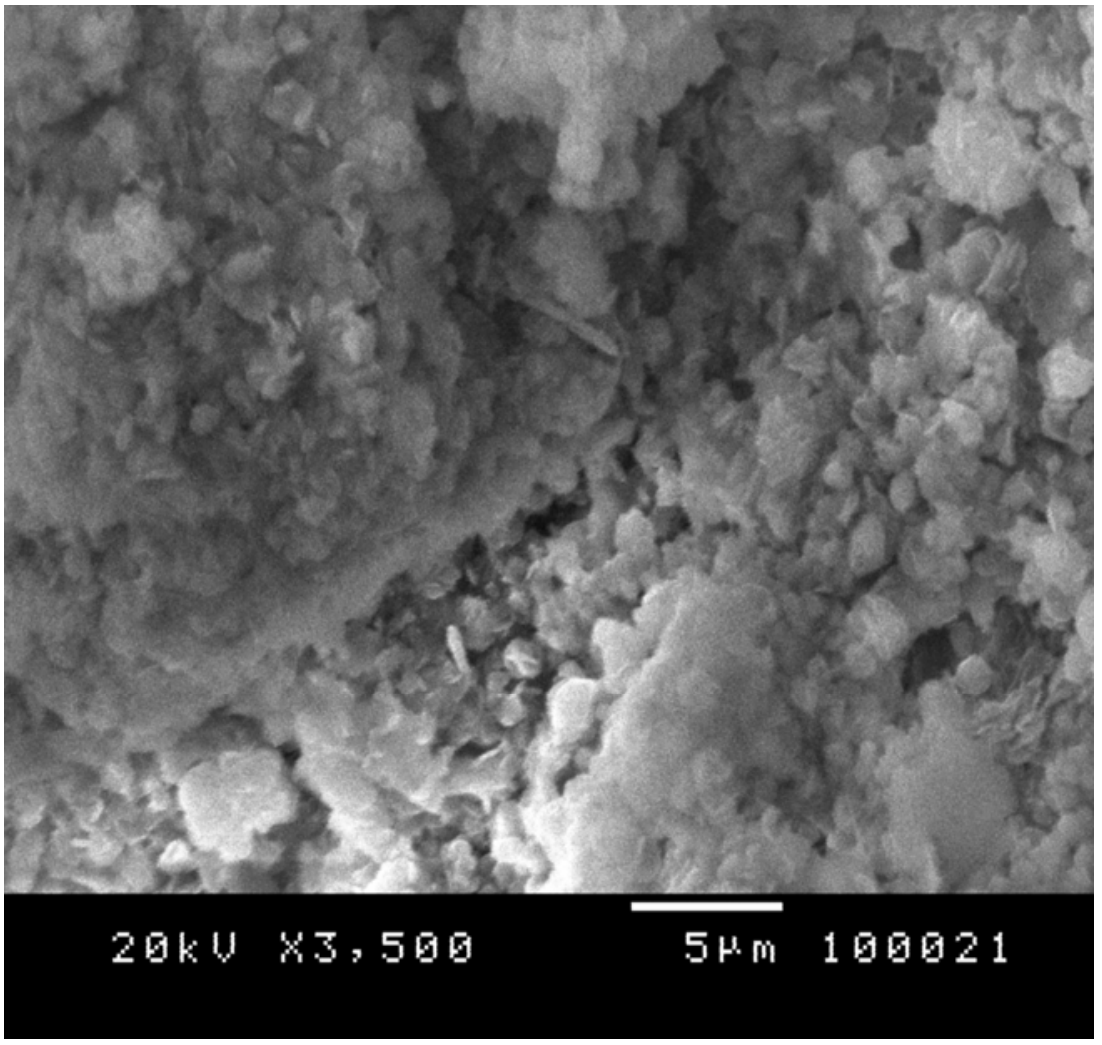

Figure 5.11: Cutter-1: 2200 mbrt illite determined using EDS 


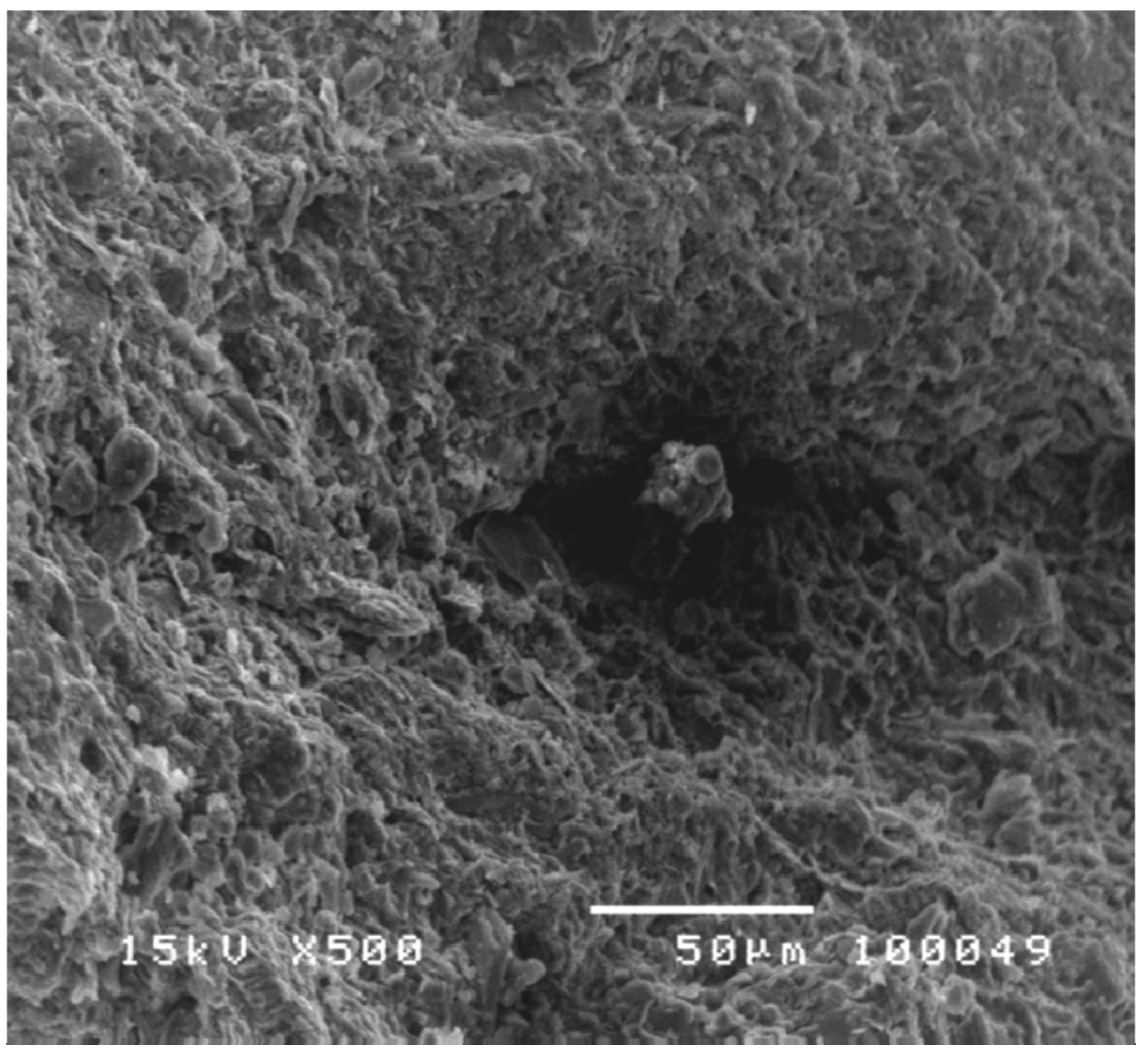

Figure 5.12: Galleon-1: 2400 mbrt SEM image illustrating mixed clay layers.

Smectite is produced from the weathering of basaltic rocks with a high availability of calcium and paucity of potassium (Larmer, 1998). This type of clay is susceptible to swelling due to weak interlayer bonding. Another important and common chemical processes in clay rich sediments (especially marine deposits) is the decomposition of organic matter. Formed by reducing bacterial sulphate, bisulphide is formed, which when partially oxidised can react with organic matter and reactive metal species to form iron sulphides, the most common being pyrite. The amount of pyrite formed in these sediments is determined by the availability of sulphate, reactive iron and reactive organic matter during the formation of these mudstones. The mineral pyrite (or iron pyrite) is iron disulfide $\left(\mathrm{FeS}_{2}\right)$ and exhibits isometric crystals that appear as cubes or pyritohedrons (twelve irregular or pentagonal sided faces). 

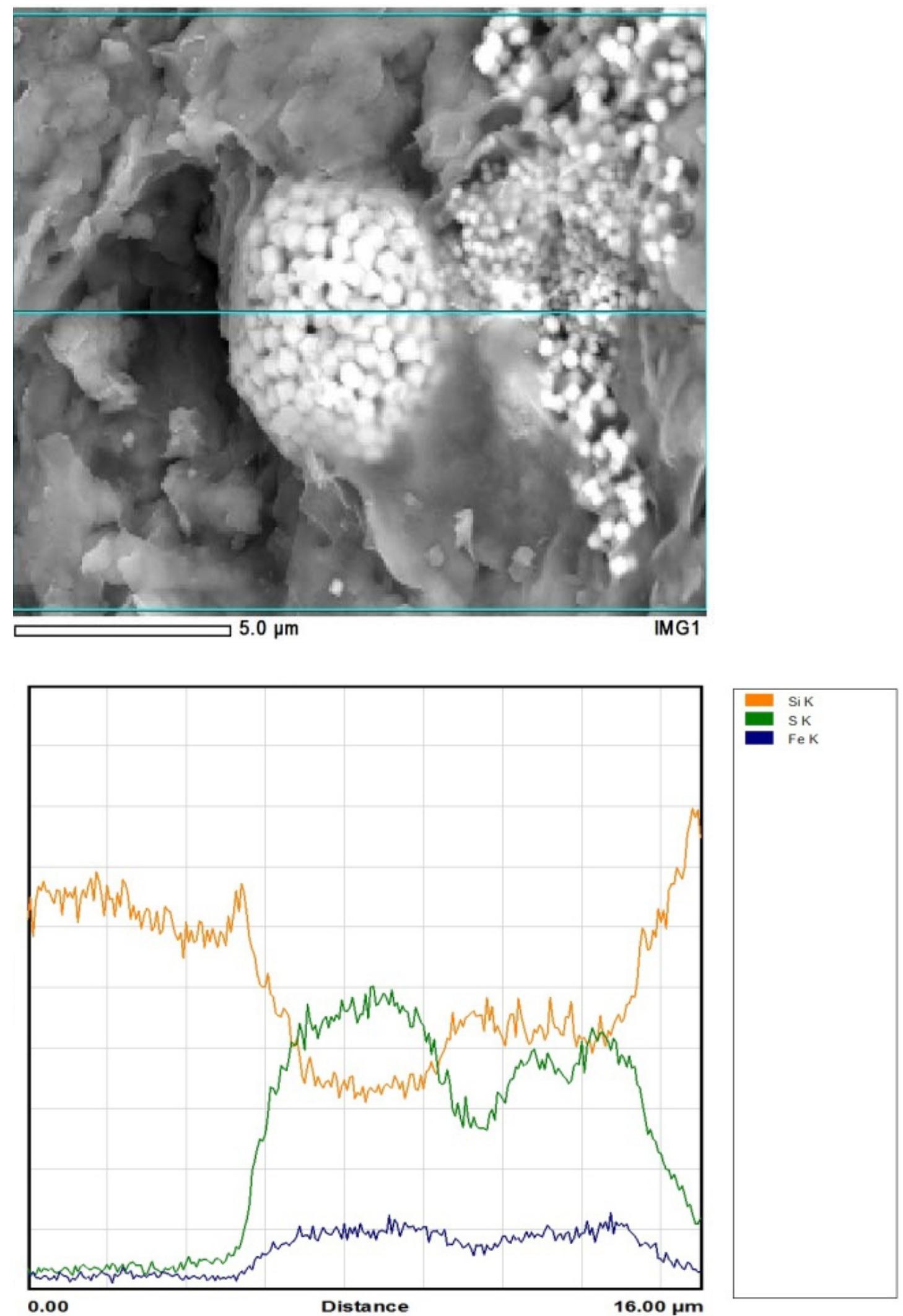

Figure 5.13: Clipper-1: 3000 mbrt SEM and EDS image.

Set in silica cement, Backscattered SEM image magnified to 7500x (left) exhibits pyritohedron architecture. Elementary signature (right) is a cross section through the horizontal line in the SEM image. It clearly illustrates silica cement, interrupted by elevated sulphur and minor iron which corresponds to pyrite growth. 
Although there was no observed evidence of radiolarian or diatoms, calcareous nannofossils (coccoliths) were noticed in abundance throughout the Otepopo Formation (only observed in Clipper-1). These were c.a. $1 \mu \mathrm{m}$ in diameter and accounted for up to $15 \%$ of the sample (Figure 5.14).



Figure 5.14: Clipper-1: 3000 mbrt SEM and EDS images.

Schematic coccospheres (Armstrong \& Braiser, 2005) illustrating individual coccoliths, which is identified in the backscattered SEM image magnified 17000x. Resulting mapping denotes the elementary composition in order of abundance; 1) Green - calcium carbonate; 2) Red - silica; and 3) Blue - iron. 
Calcareous nannofossils are minute calcareous skeletons, which include coccoliths and coccospheres, a type of haptophyte algae which are commonly found in vast numbers in marine sediments (Armstrong \& Braiser, 2005). Coccoliths are a common element of late Cretaceous to early Oligocene age sediments in New Zealand's East coast basins (McGonigal \& Di Stefano, 2002). A coccolith is a single disc-like plate which is secreted by the algal organism and held in combination with several other plates, occasionally amalgamating to form a coccosphere. Upon death, they sink through the water column forming in some cases vast chalk deposits. Individual coccoliths and coccospheres invariably become separated following death and breakup of the coccospheres or are shed continuously by some species, ultimately becoming preserved in the fossil record.

\subsection{Total Organic Carbon and Rock-Eval Pyrolysis}

Rock-Eval pyrolysis was carried out on eight samples collected from Cutter-1 using a source rock analyser (SRA) at GNS Science. As shown in Table 5.1, samples were taken from intervals of elevated gas chromatograph readings from the Kurinui Formation and underlying Moeraki Formation. This was done to investigate the possibility that gas has either migrated from deeper reservoirs or is formed in-situ in these intervals.

Despite elevated gas chromatograph readings made while drilling in the Kurinui and Moeraki formations (particularity in Cutter-1 and to a lesser extent in Clipper-1), the SRA test results from Cutter-1 indicate a limited (but not insignificant) total organic carbon value. A Modular Formation Dynamic Tester (MDT) fluid sample was taken during drilling operations at $2531 \mathrm{mbrt}$ in Cutter-1. Subsequently, this allowed identification of glycol (a drilling mud additive) which is likely to have contaminated the cutting samples. When tested in the SRA, the glycol displayed a prominent $S_{1}$ peak and therefore will contribute to the $S_{1}$ signatures from the eight Cutter-1 samples tested in this research (Table 5.1). 


\begin{tabular}{|c|c|c|c|c|c|c|c|c|c|c|}
\hline \multirow{2}{*}{ Sample } & $\mathrm{S}_{1}$ & $\mathrm{~S}_{2}$ & \multirow{2}{*}{$\begin{array}{c}\mathrm{T}_{\max } \\
\text { (c Temp) }\end{array}$} & \multirow{2}{*}{$\begin{array}{c}\mathrm{T}_{\text {peak }} \\
\text { (c Temp) }\end{array}$} & \multirow{2}{*}{$\begin{array}{c}\mathrm{S}_{3} \\
\text { (mg HC/g rock) }\end{array}$} & \multirow{2}{*}{$\begin{array}{l}\text { TOC } \\
\text { (wt \%) }\end{array}$} & \multirow{2}{*}{$\begin{array}{c}\mathrm{HI} \\
\text { (mg HC/g rock) }\end{array}$} & \multirow{2}{*}{$\begin{array}{c}\mathrm{OI} \\
(\mathrm{mg} \mathrm{CO} 2 / \mathrm{g} \\
\text { TOC) }\end{array}$} & \multirow[t]{2}{*}{ PI } & \multirow{2}{*}{$\begin{array}{c}\text { BI } \\
\text { (mg HC/g rock) }\end{array}$} \\
\hline & \multicolumn{2}{|c|}{ (mg HC/g rock) } & & & & & & & & \\
\hline 2145 & 0.24 & 1.43 & 433.5 & 472.5 & 1.27 & 1.04 & 138 & 122 & 0.14 & 23 \\
\hline 2155 & 0.27 & 1.66 & 431.5 & 470.5 & 1.11 & 1.31 & 126 & 85 & 0.14 & 21 \\
\hline 2180 & 0.27 & 1.76 & 432.8 & 471.8 & 1.00 & 1.36 & 130 & 74 & 0.13 & 20 \\
\hline 2220 & 0.28 & 2.28 & 433.0 & 472.0 & 1.02 & 1.51 & 151 & 68 & 0.11 & 19 \\
\hline 2360 & 0.27 & 1.55 & 427.0 & 466.0 & 1.43 & 1.24 & 125 & 116 & 0.15 & 22 \\
\hline 2500 & 0.49 & 3.41 & 421.3 & 460.3 & 0.65 & 1.64 & 207 & 40 & 0.13 & 30 \\
\hline 2510 & 0.65 & 4.80 & 420.8 & 459.8 & 0.48 & 1.66 & 289 & 29 & 0.12 & 39 \\
\hline 2530 & 0.43 & 1.93 & 427.2 & 466.2 & 1.05 & 1.17 & 165 & 89 & 0.18 & 37 \\
\hline $2531 *$ & 0.46 & 0.13 & 320.8 & 359.8 & 0.2 & 0.13 & 95 & 147 & 0.78 & 354 \\
\hline
\end{tabular}

Table 5.1: Cutter-1 SRA pyrolysis results.

Washed cutting samples are expressed in metres below rotary table (mbrt) * denotes MDT fluid sample collected.

TOC values in Cutter-1 for the Kurinui Formation ranged between $1.04-1.51 \%$, while underlying TOC values for the Moeraki Formation ranged between $1.17-1.66 \%$. The total average TOC value from Cutter-1 is $1.4 \%$. This value is within the range proposed by (Burford, 1975; Gibbons \& Herridge, 1984; and Gibbons \& Fry, 1986) who determined TOC values in Endeavour-1, Clipper-1 and Galleon-1 to range between $0.9-2.5 \%$ but slightly less than the average TOC of $1.6 \%$ that these previous authors had suggested for the Hampden, Kurinui and Moeraki formation sediments.

The generative potential of a source rock can be either tabulated or cross plotted to determine the likely quantity of likely hydrocarbon. These two methods have been adopted for Kurinui and Moeraki sediments in this study. Modified after (Peters \& Cassa, 1994) are the tabulated results from Cutter-1 which illustrate a 'good' generative potential (Table 5.2). All samples from Cutter-1 fell within the TOC range of $1-2 \mathrm{wt} \%$.

\begin{tabular}{|c|c|c|c|c|c|c|c|}
\hline \multirow[b]{2}{*}{$\begin{array}{c}\text { Potential } \\
\text { (quantity) }\end{array}$} & \multirow[b]{2}{*}{$\begin{array}{c}\text { TOC } \\
(\text { wt \%) } \\
\end{array}$} & \multicolumn{2}{|c|}{ Rock-Eval (mg HC/g rock) } & \multirow[b]{2}{*}{$\begin{array}{c}\text { Bitumen } \\
\text { (ppm) }\end{array}$} & \multirow[b]{2}{*}{$\begin{array}{c}\text { Hydrocarbons } \\
\text { (ppm) }\end{array}$} & \multirow[b]{2}{*}{ Formation } & \multirow[b]{2}{*}{ Depth } \\
\hline & & $\mathbf{S}_{1}$ & $\mathbf{S}_{2}$ & & & & \\
\hline Poor & $<0.5$ & $<0.5$ & $<2.5$ & $<500$ & $<300$ & $\mathrm{n} / \mathrm{a}$ & $\mathrm{n} / \mathrm{a}$ \\
\hline Fair & $0.5-1$ & $0.5-1$ & $2.5-5$ & $500-1000$ & $300-600$ & $\mathrm{n} / \mathrm{a}$ & $\mathrm{n} / \mathrm{a}$ \\
\hline Good & $1-2$ & $1-2$ & $5-10$ & $1000-2000$ & $600-1200$ & $\begin{array}{l}\text { Kurinui } \\
\text { Kurinui } \\
\text { Kurinui } \\
\text { Kurinui } \\
\text { Kurinui } \\
\text { Moeraki } \\
\text { Moeraki } \\
\text { Moeraki }\end{array}$ & $\begin{array}{l}2145 \\
2155 \\
2180 \\
2220 \\
2360 \\
2500 \\
2510 \\
2530 \\
\end{array}$ \\
\hline Very Good & $2-4$ & $2-4$ & $10-20$ & $2000-4000$ & $1200-2400$ & $\mathrm{n} / \mathrm{a}$ & $\mathrm{n} / \mathrm{a}$ \\
\hline Excellent & $>4$ & $>4$ & $>20$ & $>4000$ & $>2400$ & $\mathrm{n} / \mathrm{a}$ & $\mathrm{n} / \mathrm{a}$ \\
\hline
\end{tabular}

Table 5.2: Cutter-1: Generative potential (quantity) as determined by TOC analysis.

A cross plot of $S_{2}$ vs. TOC data (displayed in Table 5.1) illustrate the generative potential (quantity) of hydrocarbon. The limited number of Dannevirke aged samples from Cutter-1 are plotted with age 
equivalent Kurinui and Moeraki formation $\mathrm{S}_{2}$ and TOC data sets after Burford, (1975); Gibbons \& Herridge, (1984); and Gibbons \& Fry, (1986) (Figure 5.16).

Figure 5.15 illustrates varied hydrocarbon quantity with HI values ranging between $<50$ to slightly over 300. This corresponds to 'poor' to 'good' HI values. Kurinui and Moeraki sediments from Cutter-1 plot within the 'good' range of 'gas' and to a lesser extent two samples from the Moeraki Formation (2500 \& $2510 \mathrm{mbrt}$ ) which plot within the 'mixed oil and gas' range.

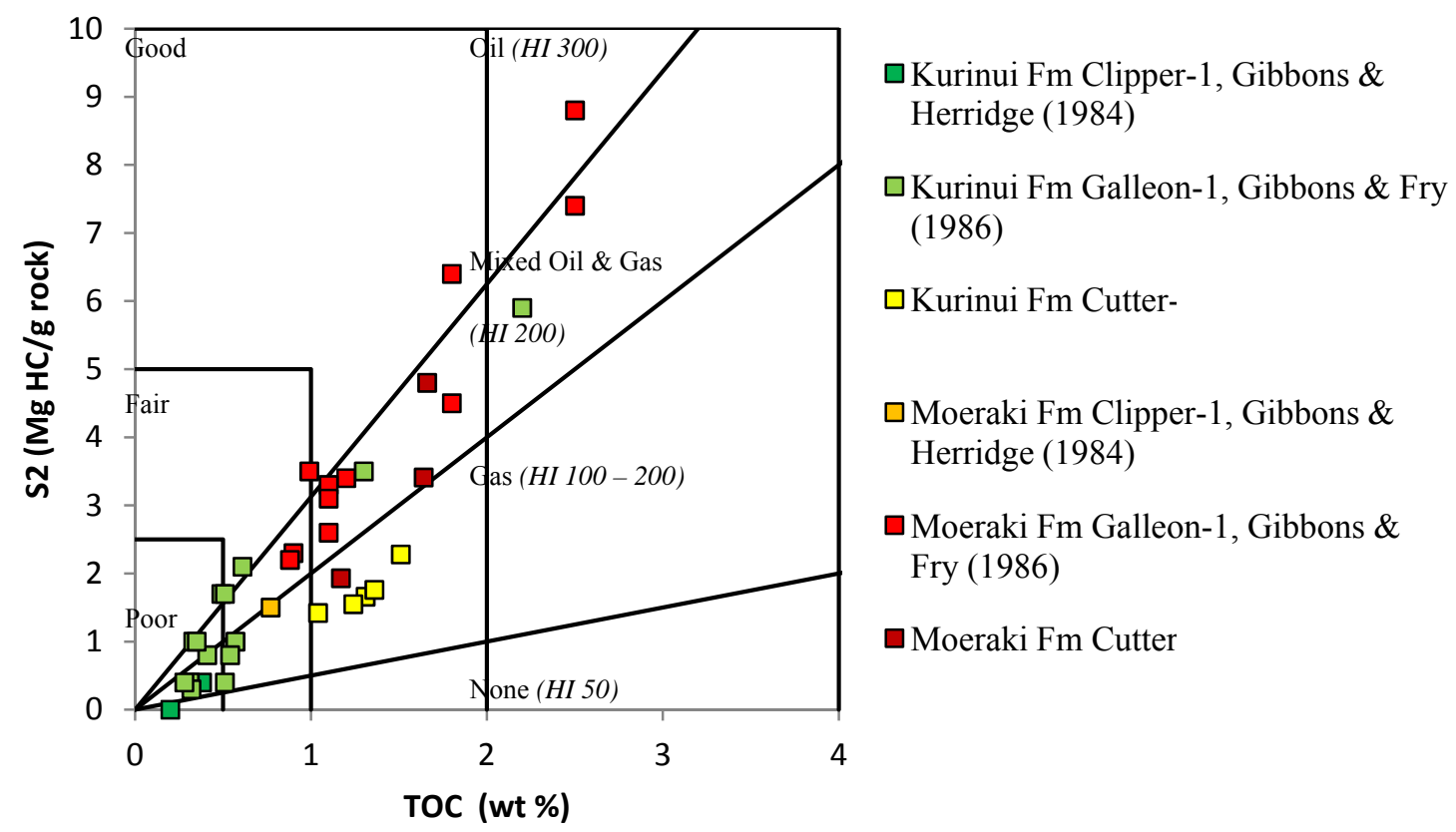

Figure 5.15: Cutter-1: Generative potential (quantity) as determined by $S_{2}$ vs. TOC cross plot.

All samples from Cutter-1 plot within the range of 'good'. Two of these samples (Moeraki 2500 \& 2510 mbrt) plot within the mixed oil and gas range.

The tabulated total organic carbon (TOC) and the $\mathrm{S}_{2}$ vs. TOC cross plot are used to measure the quantity of organic carbon in a rock or sediment sample. To measure the quality of the organic carbon, Table 5.3 is adopted after Peters \& Cassa, (1994) to display the kerogen type and expelled hydrocarbon product. HI values are used to determine the main hydrocarbon product at peak maturity. A majority of Cutter-1 samples fall within the 'gas' producing range, although a mixed 'oil and gas' (kerogen type II/III) is displayed in two of the three Moeraki samples tested. 


\begin{tabular}{|c|c|c|c|c|c|c|}
\hline $\begin{array}{l}\text { Kerogen } \\
\text { (quality) }\end{array}$ & $\begin{array}{c}\mathrm{HI}(\mathrm{mg} \mathrm{HC} / \mathrm{g} \\
\text { TOC) }\end{array}$ & $\mathbf{S}_{2} / \mathbf{S}_{3}$ & Atomic H/C & $\begin{array}{c}\text { Main product } \\
\text { at peak } \\
\text { maturity } \\
\end{array}$ & Formation & Depth \\
\hline I & $>600$ & $>15$ & $>1.5$ & Oil & $\mathrm{n} / \mathrm{a}$ & $\mathrm{n} / \mathrm{a}$ \\
\hline II & $300-600$ & $10-15$ & $1.2-1.5$ & Oil & $\mathrm{n} / \mathrm{a}$ & $\mathrm{n} / \mathrm{a}$ \\
\hline II/III & $200-300$ & $5-10$ & $1.0-1.2$ & Oil/Gas & $\begin{array}{l}\text { Moeraki } \\
\text { Moeraki }\end{array}$ & $\begin{array}{l}2500 \\
2510\end{array}$ \\
\hline III & $50-200$ & $1-5$ & $0.7-1.0$ & Gas & $\begin{array}{l}\text { Kurinui } \\
\text { Kurinui } \\
\text { Kurinui } \\
\text { Kurinui } \\
\text { Kurinui } \\
\text { Moeraki }\end{array}$ & $\begin{array}{l}2145 \\
2155 \\
2180 \\
2220 \\
2360 \\
2530 \\
\end{array}$ \\
\hline IV & $<50$ & $<1$ & $<0.7$ & None & $\mathrm{n} / \mathrm{a}$ & $\mathrm{n} / \mathrm{a}$ \\
\hline
\end{tabular}

Table 5.3: Cutter-1: Kerogen type and expelled products (quality) as determined by HI.

As discussed in section 2.2; the van Krevelen diagram is also a useful method to illustrate the atomic $\mathrm{H} / \mathrm{C}$ vs. O/C relationship which can define the three kerogen types based on differences in elemental composition. The Kurinui and Moeraki formation samples plot between kerogen types II and type III (Figure 5.16). The Kurinui Formation plots closer to the type III kerogen line; more indicative of a cellulosic source rock formed from terrestrial plant matter as opposed to type II source rocks formed from marine planktonic remains.

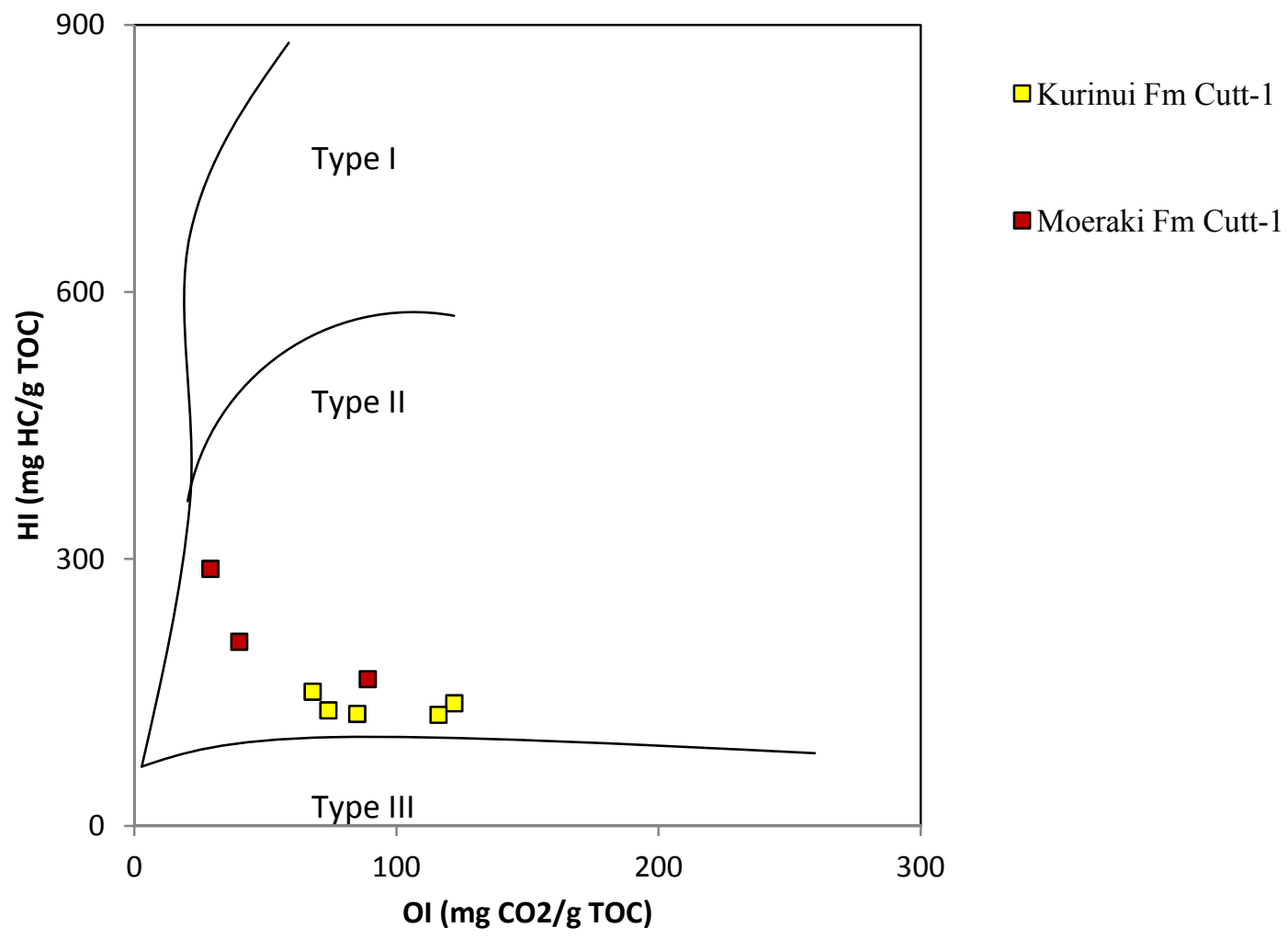

Figure 5.16: Canterbury Basin: Dannevirke Series Van Krevelen diagram.

The five Kurinui Formation samples from Cutter-1 tend to plot closer to type III kerogen while Moeraki Formation (2500 \& 2510 mbrt) samples exhibit a higher HI and lower OI and are type II/III.

Maturation data is a measure of the source rock potential to produce oil or gas. Commonly represented by vitrinite reflectance data $\left(\mathrm{R}_{0}\right)$, Cretaceous sediments in the Canterbury Basin display $R_{0}$ values in the order 
of $0.6-1.3 \%$ (Field and Browne, 1989). The highest value of 1.3\% was sourced from the Clipper SubBasin indicates early to late maturity has occurred. Few data sets are available for Dannevirke aged sediments in the Canterbury Basin. 


\begin{tabular}{|c|c|c|c|c|c|c|c|c|}
\hline Maturity & $R_{0}(\%)$ & $\mathbf{T}_{\max }\left({ }^{\circ} \mathrm{C}\right)$ & $\begin{array}{c}\text { Thermal Alteration } \\
\text { Index }\end{array}$ & $\begin{array}{l}\text { Bitumen/ } \\
\text { TOC }\end{array}$ & $\begin{array}{c}\text { Bitumen } \\
\text { (mg/g rock) }\end{array}$ & $\begin{array}{c}\text { Production } \\
\text { Index } \\
\left\{\mathrm{S}_{1} /\left(\mathrm{S}_{1}+\mathrm{S}_{2}\right)\right\}\end{array}$ & Formation & Depth \\
\hline Immature & $0.20-0.60$ & $<435$ & $1.5-2.6$ & $<0.05$ & $<50$ & $<0.10$ & $\begin{array}{l}\text { Kurinui } \\
\text { Kurinui } \\
\text { Kurinui } \\
\text { Kurinui } \\
\text { Kurinui } \\
\text { Moeraki } \\
\text { Moeraki } \\
\text { Moeraki } \\
\end{array}$ & $\begin{array}{l}2145 \\
2155 \\
2180 \\
2220 \\
2360 \\
2500 \\
2510 \\
2530 \\
\end{array}$ \\
\hline Mature & & & & & & & $\mathrm{n} / \mathrm{a}$ & $\mathrm{n} / \mathrm{a}$ \\
\hline Early & $0.60-0.65$ & $435-445$ & $2.6-2.7$ & $0.05-0.10$ & $50-100$ & $0.10-0.15$ & $\mathrm{n} / \mathrm{a}$ & $\mathrm{n} / \mathrm{a}$ \\
\hline Peak & $0.65-0.90$ & $445-450$ & $2.6-2.7$ & $0.15-0.25$ & $150-250$ & $0.25-0.40$ & $\mathrm{n} / \mathrm{a}$ & $\mathrm{n} / \mathrm{a}$ \\
\hline Late & $0.90-1.35$ & $450-470$ & $2.9-3.3$ & - & - & $>0.40$ & $\mathrm{n} / \mathrm{a}$ & $\mathrm{n} / \mathrm{a}$ \\
\hline Postmature & $>1.35$ & $>470$ & $>3.3$ & - & - & - & $\mathrm{n} / \mathrm{a}$ & $\mathrm{n} / \mathrm{a}$ \\
\hline
\end{tabular}

Table 5.4: Cutter-1: Thermal maturity as determined by $\mathrm{T}_{\max }\left({ }^{\circ} \mathrm{C}\right)$.

\subsection{Summary}

Sixty three data sets additional to published Dannevirke aged Clipper Sub-Basin samples were created. Cutting samples were collected over an interval thickness of several hundred metres. Samples were separated and distinguished from in-situ, downhole-caved lithologies and drilling muds/induced lithologies.

1. Samples examined under the polarising microscope are all fine grained, mud-rich with $0-20 \%$ sand sized grains. The mineralogy is dominated by quartz with lithics, and feldspar is rare or absent. Clay minerals have formed from the decomposition and replacement of unstable lithic grains and feldspar as well as from detrital mud. Quartz is sub angular to angular silt grade (16$32 \mu \mathrm{m}$ ) with less abundant calcite, pyrite and organic debris and trace feldspar, mica and localised glauconite. Quartz is the dominant mineral observed in all samples and is commonly polycrystalline (undulose). These samples were plotted on a composite QFL diagram and classified as sublitharenite.

2. The intensity of the XRD diffraction patterns are pronounced with quartz and to a lesser extent calcite contributing to a spiky appearance, which implies a well ordered and highly crystalline mineralogy. Subordinate mixed layer clay comprised kaolinite and to a lesser extent illite and smectite abundances. Semi-quantitative analyses illustrate quartz abundance ranged between $22 \mathrm{wt} \%$ at $1600 \mathrm{mbrt}$ in Endeavour-1 and $71.5 \mathrm{wt} \%$ at $2526 \mathrm{mbrt}$ in Cutter-1. Mixed layer clay ranged in average value between $11 \mathrm{wt} \%$ at $2550 \mathrm{mbrt}$ in Galleon- 1 and $60.3 \mathrm{wt} \%$ at $2360 \mathrm{mbrt}$ in Cutter-1. Where quartz weight percentages are high there is corresponding low clay weight percentage. This relationship is recognised most noticeably in intervals of elevated total gas chromatograph readings. 
3. No obvious diatomaceous or radiolarian bearing lithology was noted in any sample. Previous work had suggested a biogenic origin for silica in age equivalent sediments, so these findings were unexpected. Large siliceous blooms were proposed for late Paleocene siliceous sediments to the north in the Marlborough region by Hollis et al., (1995). The results of this thesis are consistant with the conclusion of Morgans (2009) who reported minor radiolarian populations at the Hampden Beach section during the Paleocene to early Eocene. The source of silica is thought to be derived from alteration of clays and feldspar. Crystalline quartz was noted throughout all samples, varying in angularity and size, typically $<20 \mu \mathrm{m}$. Clay minerals comprise kaolinite, illite and smectite, which are considered authigenic as they are strongly crystalline. The majority of samples are well compacted and tend to align parallel to each other. Diagenetic products observed included pyrite and calcite, likely to be a product of high porosity and fluid flow during early stages of shallow burial.

4. The Kurinui and underlying Moeraki formations exhibit HI values less than 435, indicating they are immature. The TOC values ranged between 1.16 and $2.04 \%$ and although significant enough to produce gas and a mixed oil and gas product at peak maturity, they are organically lean. This suggests elevated total gas observed in Cutter-1 has two possible origins. The first being thermogenic gas migrating from a near-to-source charge and second an in-situ biogenic gas. 


\subsection{Results and Interpretation of Well Based Data}

\subsection{Open Hole Wireline Logs}

The use of wireline and image logs enhances the accuracy of any stratigraphic model. Wireline logs should always be used in conjunction with contemporary seismic and biostratigraphic interpretation to ensure stratigraphic reliability (Rider, 2002). Wireline log data is recorded in the open hole environment before casing is run into the borehole. Facies differences are identified by relative change associated with; 1) density; 2) porosity and pore fluid type; 3) resistivity; 4) acoustic; and 5) natural radioactivity logs. These are geophysical properties which allow correlation between wells to be made. Four offshore wells; Endeavour-1, Clipper-1, Galleon-1 and Cutter-1 had a full suite of wireline logs run (Enclosure 1: Openhole logs). Cutter-1 has an additional advancement; Fullbore Formation MicroImager (FMI) and quality control logs which were run over the Dannevirke aged sediments. All these data was used in this thesis.

\subsection{Wireline Correlations}

A sharp contact is observed immediately beneath the Amuri Limestone, where logs from all wells display a major step change. A notable decrease in acoustic, density and resistivity logs corresponds to an increase in gamma when mudrocks of the Dannevirke Series are encountered. Throughout the Dannevirke Series, localised changes in lithology and preceding depositional conditions cause variation in the wireline signature, in particular the gamma signature (Figure 6.1). According to Rider, (2002), gamma peaks can represent shale sequences of maximum flooding events and are effectively time lines in the sediment record. The Tartan Formation and to a lesser extent intervals in the Moeraki Formation represent such flooding surfaces where gamma values are typically over 150 API units. Conversely, gamma values less than 65 API are considered sandier as quartz exhibits little or no radioactivity. Similarly mudstone with low gamma values may be potassium, thorium or uranium deficient. All gamma tracks have been shaded yellow where gamma values crossed less than 65 API units. Clipper-1 is the only well to display a consistently lower gamma signature throughout the Dannevirke Series, whereas the remaining three wells display relatively 'clean' shale properties.

With increased depth, the Dannevirke Series sonic and density responses increase in all wells. This is to be expected as effective overburden pressure increases, but of note are zones where neutron porosity increases and density values decrease, occasionally crossing over. Such zones indicate environments where fluid may be migrating or accumulating and are illustrated by green shading when in shale and yellow shading when in a sandier lithology. Although these intervals are expressed in Figure 6.1, a better resolution can be viewed in Enclosure 1: Openhole logs.

Dannevirke aged sediments in all four wells display reduced gamma and neutron-density cross over intervals of variable thickness; typically within less than five metre intervals. Total gas readings are also elevated in these intervals suggesting accumulation and migration is occurring in zones of enhanced 
porosity. The Otepopo Formation in Clipper-1 also displays good density porosity cross over, but is known to be a sandier lithology and not related to shale gas potential. 


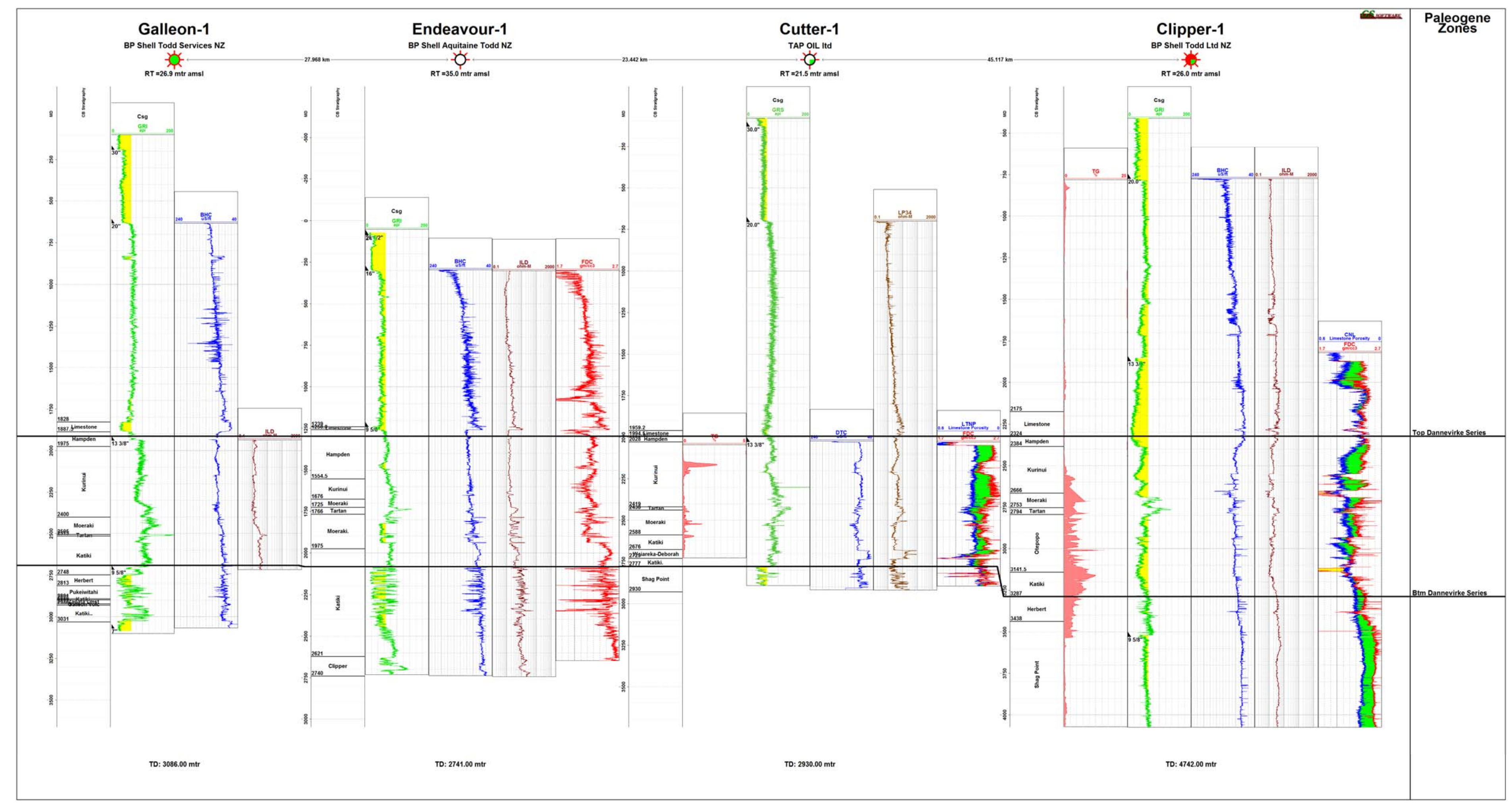

Figure 6.1: Clipper Sub-Basin: Wireline well correlation

typically of sand. Neutron-Density cross over's have been plotted yellow. Dannevirke Series was picked using biostratigraphic records and correlated to wireline signatures to find stratigraphic boundaries. An anced scale for each log can be sourced from Enclosure 1: Openhole logs. 


\subsubsection{Katiki Formation}

The Katiki Formation attains a maximum thickness in the Galleon-1 well of c.a. $513 \mathrm{~m}$ where three units are recognised (Figure 6.1). Biostratigraphic boundaries spanning Piripauan to Teurian aged sediments define an upper, middle and lower unit (Pocknall et al., 1991). The upper unit is interpreted to be near shore or paralic, the middle unit fully marine, and the lowermost unit a nonmarine environment. The presence of concretions and stringers of dolomite in Galleon-1 yield a characteristic spiky appearance to the Katiki Formation log response, in particular the gamma log (Figure 6.2). This is not as pronounced in the remaining 3 wells where a uniform signature is recognised by a slight decrease downhole in gamma and resistivity response.

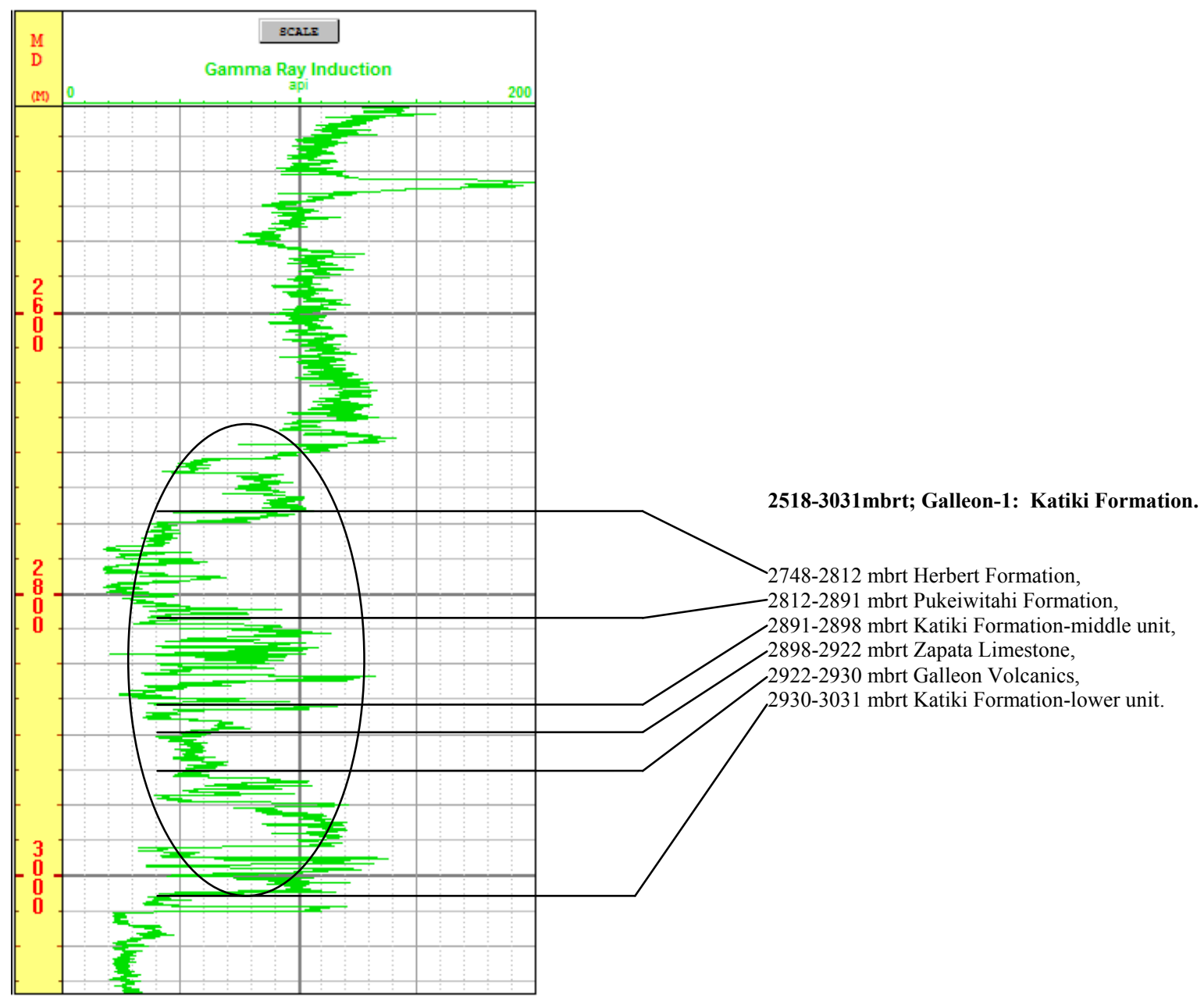

Figure 6.2: Galleon-1: Gamma response.

Black circle outlining Katiki Formation 'spiky' gamma log signature. MD denotes measured depth in metres.

\subsubsection{Moeraki Formation}

The Moeraki Formation is thickest in the Endeavour-1 well, where approximately $300 \mathrm{~m}$ of sediment is recorded. The wireline logs display a relatively high gamma signature down hole, typically over 150 API units. In Cutter-1, gas chromatograph readings display accumulation of wet gas (>IC4) throughout the 
entire formation (2438-2588 mbrt) (Figure 6.3). Neutron-density and gamma log responses in this interval suggest this is a zone of fissile or thinly laminated shale.

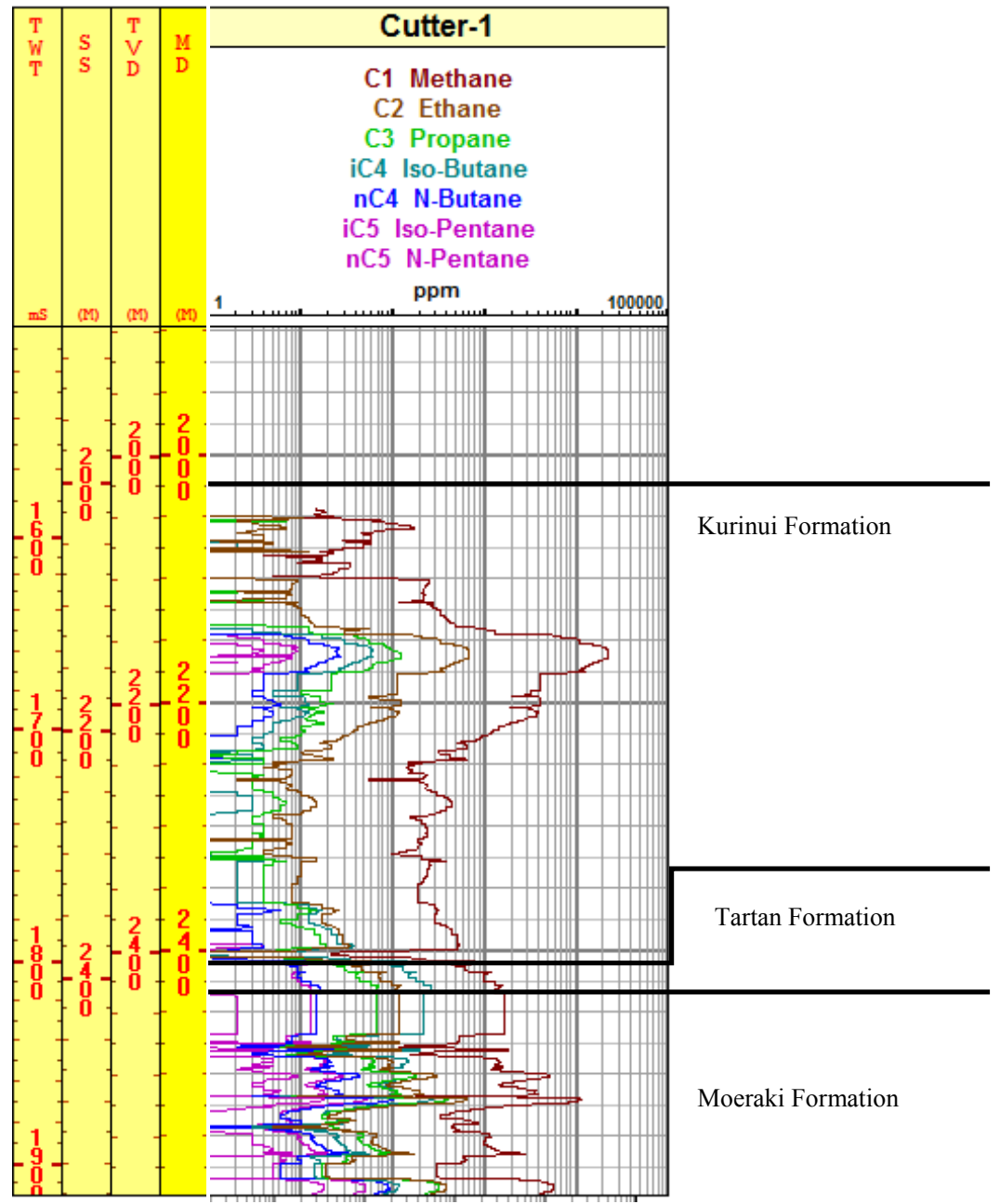

Figure 6.3: Cutter-1: Gas chromatograph readings.

The largest Total Gas (TG) reading is in the Kurinui Formation where $2.71 \%$ at c.a. 2165 is recorded. TWT: two way travel time, SS: sub seafloor, TVD: True vertical depth, MD: measure depth.

\subsubsection{Tartan Formation}

The Tartan Formation is present in all wells, and has a top marked by an increase in gamma, resistivity and acoustic values. Characteristic API values are typically between 150 and 190 API units; much higher than the Moeraki Formation. Elevated acoustic and resistivity signatures values are characteristic of the Tartan Formation. It is thickest in the Clipper-1 well, where $41 \mathrm{~m}$ is recorded.

\subsubsection{Kurinui Formation}

This may be reflected in the coarsening upwards succession noted in the gamma response at the top of the Kurinui Formation as it grades into the overlying Hampden Formation. The Kurinui Formation is thickest in the Galleon-1 well, where $425 \mathrm{~m}$ of sediment is recovered. The Kurinui Formation also exhibits wet gas (>IC4) between 2140 - 2250 mbrt in Cutter-1 and 2450 - 2530 mbrt in Clipper-1. 


\subsubsection{Hampden Formation}

The top of the Hampden Formation is marked by a sharp contact into the overlying Amuri Limestone. A marked changed in wireline log character is visible whereby a sharp increase in gamma and sonic response clearly define the top of the mudstone succession. The Hampden Formation is thickest in the Endeavour-1 well, where $256.5 \mathrm{~m}$ of sediment was recorded. Published biostratigraphy puts the Dannevirke and overlying Arnold Series boundary within the Hampden Formation in Endeavour-1 and Galleon-1 (Pocknal et al., 1991). This boundary is not clearly defined in Clipper-1 but is biostratigraphically constrained in Cutter-1 (Raine \& Schioler, 2007). Background gas levels were recorded between 1887.5 - 1950 mbrt in Galleon-1.

\subsubsection{Gas Chromatograph}

Gas chromatograph readings were made in all wells drilled in the Clipper Sub-Basin. All but Cutter-1 required gas signatures to be digitised using spatially aware software. The process of digitising these data may have led to minor errors in total gas percentage resolution. Endeavour-1 and Galleon-1 displayed minor total gas signatures throughout the Dannevirke Series whereas Clipper-1 and Cutter-1 display representative total gas readings up to c.a. 5\% throughout the Dannevirke Series. Digitised gas signatures from these older wells (such as Clipper-1) must be considered with caution as several factors are known to affect their integrity, factors such as multiple trip gas readings in Clipper-1 between 2650 - 4750 mbrt, up to c.a. $36 \%$ at 3140 mbrt.

\subsection{Summary}

Six sets of wireline tools were run in the four wells completed in the Clipper Sub-Basin. This produced valuable stratigraphic information, which used in conjunction with biostratigraphic data, allows enhanced formation resolution which is outlined below;

1. The Dannevirke Series illustrates little obvious step changes in wireline character. Biostratigraphic records (Pocknall et al., 1991; Raine \& Schioler, 2007; and Raine, 2008) were required to set or estimate formation boundaries, in particular the Hampden to Kurinui Formation transition which illustrated little difference in wireline response.

2. A slight decrease in the gamma signature is recorded throughout the Dannevirke Series sediments. A characteristic bell shaped pattern on the Dannevirke Series gamma logs is indicative of a coarsening upward succession reflecting a decrease in clay content upward. A 'spiky' gamma signature observed during in the Paleocene to Eocene succession, particularly in Cutter-1 may represent rapid fining up sequences followed by coarsening up sequences. This is interpreted as events associated with the Paleocene Eocene Thermal Maximum (PETM) and subsequent cooling. 
3. Gas Chromatograph readings throughout the Dannevirke Series in all four wells suggest total gas was limited to discrete intervals. These intervals correspond to zones of elevated silica. It is important to note the adverse effect trip gas had on the chromatograph record (Section 4.6), particularly in Clipper-1 where total gas readings reached 36\%.

\subsection{Full Bore Formation MicroImaging}

\subsubsection{Kurinui and Moeraki Formation Structural Analysis}

Eight structural zones were identified in the Cutter-1 well between 2050 and 2600 mbrt based on slight changes in dip angle and/or orientation as determined by FMI analysis. Average dip magnitudes varied in these eight zones between $1^{\circ}$ and $11^{\circ}$ relative to horizontal. These structural zones were derived by first plotting a dip azimuth walkout diagram (Figure 6.4). A dip azimuth walkout plot is read from the bottom depth to the top depth. Where clear breaks in mudstone dip azimuth occur, a structural break is inferred. The most obvious structural break in Cutter-1 occurred between 2360 - 2392m where average dip directions changed from NNW to SE back to NNW. This break does not correspond with a recognised break in the biostratigraphic record (Raine \& Schioler, 2007) but should also be considered as a possible slump or channel deposit. 


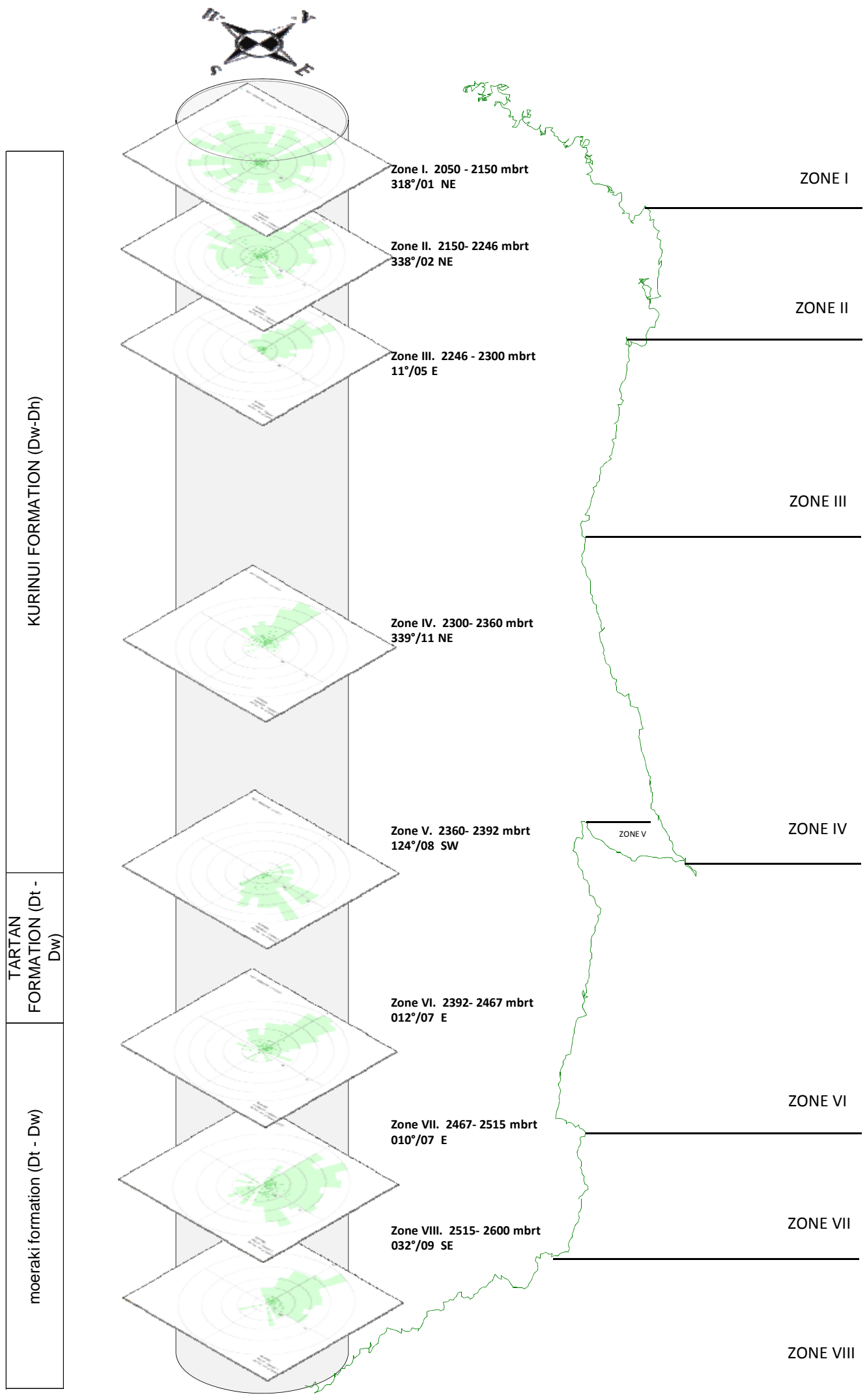

ZONE I

NE II

NE III 
diagram graphically illustrates the dip azimuth $\left(90^{\circ}\right.$ to strike) relative to north between depths of $2050 \mathrm{~m}-$ 2600mbrt in Cutter-1. This provides a useful means of visualising structural influences such as faulting and basin subsidence which occurred during mudstone deposition. Although this is to be expected in gently dipping strata, azimuth directions (and dip angles) become pronounced from zones three to eight (Table 6.1). This is likely to be a function of either; 1) renewed faulting and extension of deeper Cretaceous faults; 2) basin subsidence rates slowing; and 3) fluctuating sediment supplies.

\begin{tabular}{|c|c|c|c|c|}
\hline International Age & NZ Series & Structural Zone & $\begin{array}{l}\text { Depth } \\
\text { (mbrt) }\end{array}$ & $\begin{array}{l}\text { Average } \\
\text { Strike/Dip }\end{array}$ \\
\hline Ypresian to mid Lutetian & Waipawan (Dw) to Heretaungan (Dh) & I & $2050-2150 \mathrm{~m}$ & $318^{\circ} / 01 \mathrm{NE}$ \\
\hline Ypresian to mid Lutetian & Waipawan (Dw) to Heretaungan (Dh) & II & $2150-2246 \mathrm{~m}$ & $338 \% 02 \mathrm{NE}$ \\
\hline Ypresian to mid Lutetian & Waipawan (Dw) to Heretaungan (Dh) & III & $2246-2300 \mathrm{~m}$ & $011 \% 05 \mathrm{E}$ \\
\hline Ypresian to mid Lutetian & Waipawan (Dw) to Heretaungan (Dh) & IV & $2300-2360 \mathrm{~m}$ & $339^{\circ} / 11 \mathrm{NE}$ \\
\hline Ypresian to mid Lutetian & Waipawan (Dw) to Heretaungan (Dh) & $\mathrm{V}$ & $2360-2392 \mathrm{~m}$ & $124 \% 08 \mathrm{SW}$ \\
\hline Danian to early Ypresian & Teurian (Dt) to Waipawan (Dw) & VI & $2392-2467 \mathrm{~m}$ & $012 \% 07 \mathrm{E}$ \\
\hline Danian to early Ypresian & Teurian (Dt) to Waipawan (Dw) & VII & $2467-2515 \mathrm{~m}$ & $10^{\circ} / 007 \mathrm{E}$ \\
\hline Danian to early Ypresian & Teurian (Dt) to Waipawan (Dw) & VIII & $2515-2600 \mathrm{~m}$ & $032 \% 09 \mathrm{SE}$ \\
\hline
\end{tabular}

Table 6.1: Cutter-1: 2050 - 2600mbrt showing FMI interpreted structural zones.

Note: A general steepening of structural zones away from horizontal occurs below $2300 \mathrm{mbrt}$. This may reflect an unconformity below this depth or a localised winnowing affect above this depth where sediment has been sorted and deposited as horizontal stratification.

\subsubsection{Fracture Analysis}

Fracture analysis is dependent upon a resistivity contrast between the host rock and the fracture. Resistivity contrasts are present in Cutter-1 where 21 natural fractures are recognised (Table 6.2). The siliceous facies of the Kurinui Formation displayed the greatest fracture frequency and is considered brittle relative to the more ductile Tartan Formation which did not display any fractures. Being a vertically drilled hole; care was required when identifying fractures, particularly those with a dip below $40^{\circ}$. This was to ensure other high-angle localised features such as slump deposits, channel incision and drape bedforms were not misinterpreted 


\begin{tabular}{|c|c|c|c|c|}
\hline 胥 &  & 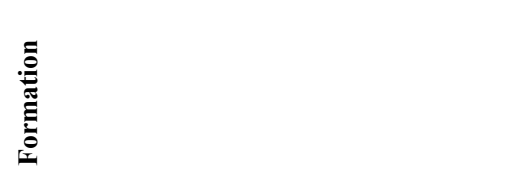 & $\ddot{\Xi}$ & 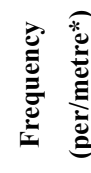 \\
\hline $\begin{array}{l}\text { Late Lutetian to } \\
\text { Priabonian }\end{array}$ & Porangan (Dp) - Bortonian (Ab) & Hampden (1994.5- 2028.0) & N/A & N/A \\
\hline Ypresian to mid Lutetian & Waipawan (Dw) - Heretaungan (Dh) & Kurinui (2028.0-2419.0) FMI start at 2050m & 3 & $1 / 13$ \\
\hline Ypresian to mid Lutetian & Waipawan (Dw) - Heretaungan (Dh) & Kurinui Siliceous (2142.8-2213.1) & 7 & $1 / 10$ \\
\hline Danian to early Ypresian & Teurian (Dt) - Waipawan (Dw) & Tartan $(2392.0-2419.0)$ & 0 & 0 \\
\hline Danian to early Ypresian & Teurian (Dt) - Waipawan (Dw) & Moeraki (2419.0-2588.0) & 10 & $1 / 17$ \\
\hline $\begin{array}{l}\text { Maastrichtian to } \\
\text { Thanetian }\end{array}$ & Haumurian (Mh) - Teurian (Dt) & Katiki (2588.0-2770.3) FMI end at 2600m & 1 & $1 / 12$ \\
\hline
\end{tabular}

Table 6.2: Cutter-1 2050 - 2600mbrt FMI interpreted natural fractures.

The highest fracture frequency is observed in the Kurinui siliceous facies interval. This is likely to be a product of the high quartz brittle lithology which is markedly different to the organic rich relatively ductile Tartan Formation. * Fracture frequency refers to the number of fractures in a given unit of thickness e.g. 1 fracture in 13 metres.

\subsubsection{Fracture Distribution}

Fracture distribution observed between 2050 - 2600m appears to be lithology dependant with calculated average natural fractures measuring one natural fracture per 26 metres (Enclosure 2). In the siliceous interval observed in the Kurinui Formation approximately one natural fracture per 10 metres were recognised while in the Moeraki Formation, approximately one natural fracture per 17 metres is determined. XRD analysis indicates that in Cutter-1 discrete zones of elevated silica and low clay ratios were evident; and these were coincident with elevated gas readings. It is therefore quite possible that fracture porosity is aiding gas migration and accumulation.

\subsubsection{Fracture Characteristics}

The dominant fracture type is resistive (bright) exhibiting very narrow aperture widths. Bright fractures in borehole images are normally interpreted as closed due to mineralisation, most commonly by carbonate or sulphide minerals and to a lesser extent by conductive drilling mud smear. Only one conductive fracture (dark) was observed, this being in the Moeraki Formation at 2390mbrt, which was likely to be attributed to clay smear in the borehole. The dominant fracture type is resistive, with 20 fractures corresponding to zones of elevated gas. It is reasonable to assume that enhanced fracture porosity may be aiding free-gas migration and storage.

\subsubsection{Fracture Orientation}

The predominant fracture direction in Cutter-1 is NE-SW, which corresponds to $\mathrm{Sh}_{\min }$ orientations observed in the Kurinui and Moeraki Formation (Figure 6.5). Irregular fracture orientations also occur, most noticeably in the Moeraki Formation between 2525 - 2545mbrt, where five alternating resistive fracture orientations are observed. 


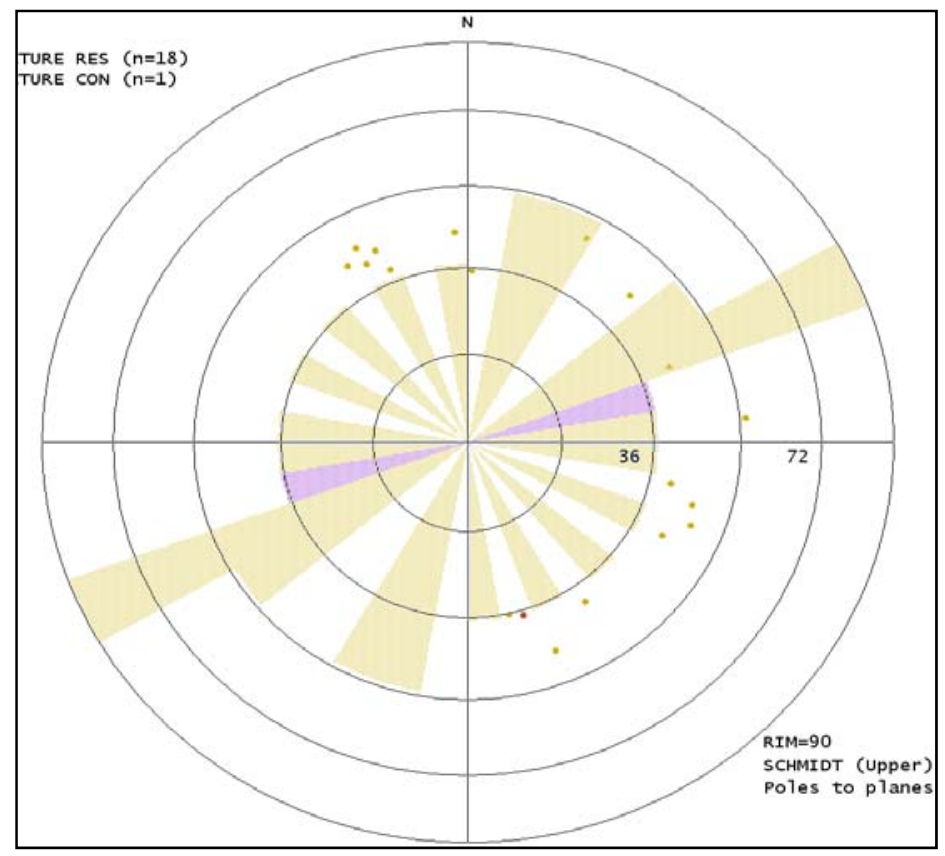

Figure 6.5: Cutter-1: Fracture orientation rose diagram.

Predominant natural fracture orientation strikes NE-SW, where conductive fractures are purple and resistive fractures are orange.

\subsubsection{In-Situ Stress}

In a vertical well, drilling-induced tension fractures (DITF) and borehole breakouts are direct measures of the prevailing horizontal in-situ stress orientations. Breakouts can be readily identified in Cutter-1 particularly between 2550-2600mbrt in the lower Moeraki and upper Katiki Formation, which indicates that $\mathrm{Sh}_{\min }$ strikes NE-SW. DITF or the $\mathrm{Sh}_{\max }$ direction strikes NW-SE and occurs principally throughout the gaseous siliceous interval of the Kurinui Formation. Maximum stress directions observed in Cutter-1 correspond to findings presented by Heidbach et al., (2009) on a world stress map (Figure 6.6). This map includes New Zealand and in particular the Pacific plate margin with corresponding $\mathrm{Sh}_{\max }$ orientations, where maximum stress directions align NW-SE in the Marlborough and Canterbury region and rotate to a predominately W-E trend in the Puysegur Trench. 


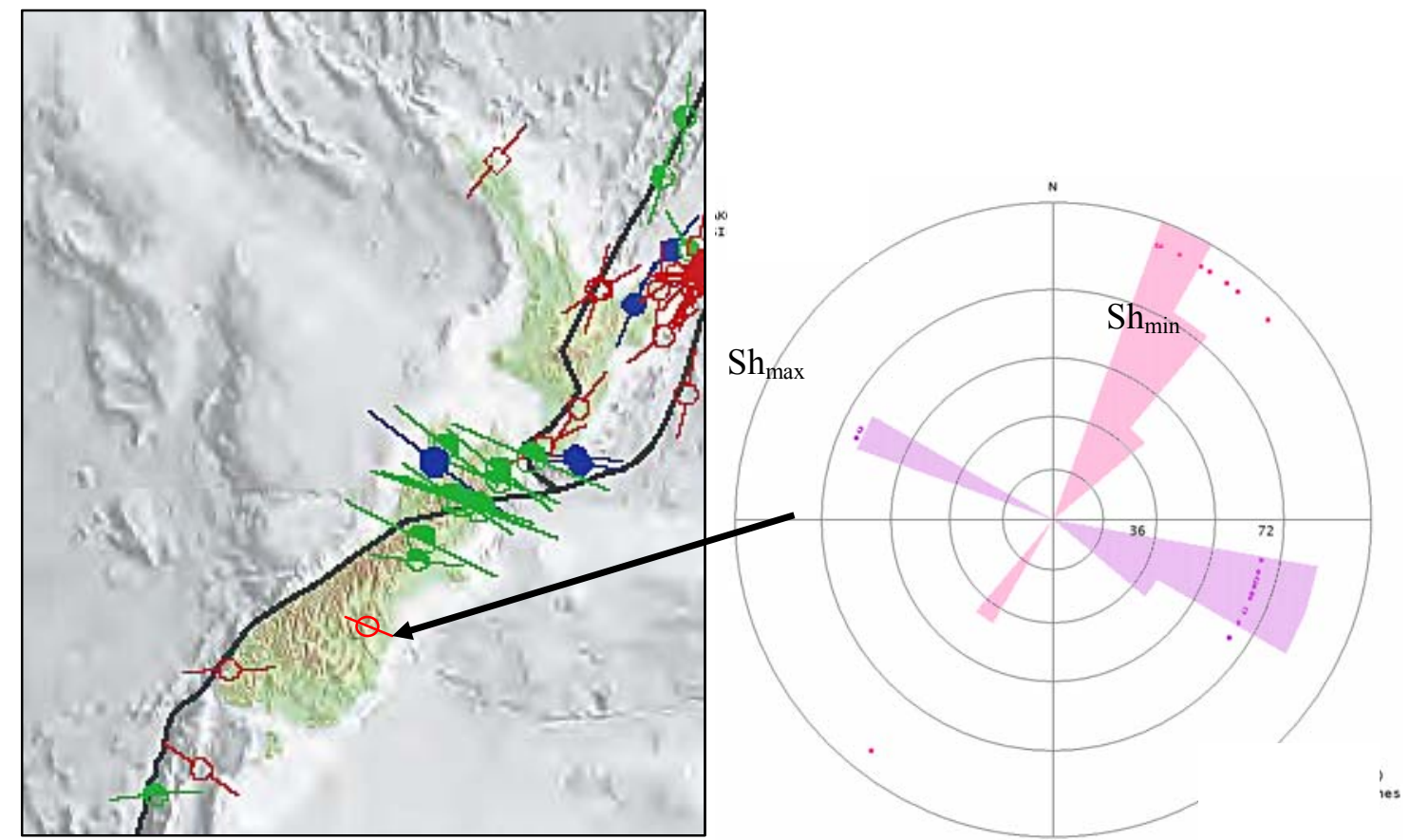

Figure 6.6: Cutter-1: DITF rose diagram and World Stress Map.

Purple are drilling induced tensile fractures (NW-SE) which is the maximum stress direction, pink are borehole breakouts (NE-SW) and are the minimum stress direction. Superimposed on New Zealand Map are findings from the World Stress Map, Green - strike slip focal mechanism, blue - thrust faulting, red - normal faulting. Modified after Heidbach et al., (2009).

Lithology may also be a controlling factor in borehole break out, however, it must be noted that the presence of breakouts may also be due to a number of other factors other than in-situ stresses. These factors include: 1) excessive weight on bit during drilling; 2) hydrostatic forces (heavy mud weight); 3) torsional stress/bit rotation; and 4) unloading.

\subsection{Summary}

Analysis of the FMI log illustrates several important structural and sedimentary factors that may be affecting free gas migration and storage in the Cutter-1 well and are discussed below;

1. Most noticeable is the relationship between elevated gas chromatograph readings and increased fracture frequency in the Kurinui siliceous facies and the Moeraki Formation. A fine grained lithology is prone to brittle deformation, particularly when elevated in silica content. Brittle state fractures of fine grained sediments could be occurring in response to over-pressured intervals, continued movement of the Alpine Fault and other faults within the basin or perhaps the migrating intrusive activity associated with the Miocene Deborah- Waiareka volcanics.

2. Low gamma, density and porosity wireline responses indicate very closely spaced silty or sandy laminations occur throughout the siliceous interval in the Kurinui Formation and the lower Moeraki Formation. This could suggest greater porosity in the horizontal plane relative to the vertical, suggesting a near-to-source hydrocarbon charge allowing free-gas to accumulate. 
3. Near horizontal mudstone bedding corresponds to intervals of increased gas chromatograph readings in the Kurinui and Moeraki Formations. Where background gas is very low, the dip of mudstone bedding increases (Table 6.1). Post-deposition structural tilting of sediment may have caused gas to migrate up inclined laminations.

4. DITF in Cutter-1 correspond with $\mathrm{Sh}_{\max }$ directions as prescribed by the Heidbach et al., (2009) world stress map. 


\subsection{Discussion}

\subsection{Introduction}

Unconventional hydrocarbon resources contained in low porosity and low permeability rocks are potentially a large source of natural gas. Recent developments throughout the United States and on the East Coast of Australia signify a shift in exploration efforts from conventional natural gas targets, towards shale gas plays and BCGS (Spencer, 1997; Boyer et al., 2006; Campbell, 2009). This is due in part to the depletion of conventional targets, but also acknowledgement of large scale unconventional gas potential (The Economist, 2010). The notion of a BCGS has gained momentum throughout the United States where approximately 30 large scale systems are identified (Popov et al., 2000). Commercially viable shale gas discoveries are also recognised throughout Canada (Ross \& Bustin, 2008 and references therein) and, perhaps more importantly in New Zealand, namely the Whangai Formation in the East Coast Basin. Deep basin conditions and thick transgressive successions are also present in much of the east coast New Zealand Paleogene sedimentary succession (Field \& Browne, 1989; Field \& Uruski, 1997; and Cook et al., 1999).

\subsection{Analogous Unconventional Hydrocarbon Systems}

If an unconventional gas system is present in the Clipper Sub-Basin, whereby wet gas is preferentially accumulating in low porosity and low permeable rocks, the two potential analogues should be considered (Table 7.1).

1. The Whangai Formation of the East Coast Basin. This is considered to be a shale gas play of similar age and composition to early Paleocene mudstones of the Clipper Sub-Basin.

2. The Monterey Formation, of the Santa Maria Basin in California, which is a producing BCGS play. 


\begin{tabular}{|c|c|c|c|c|c|c|c|}
\hline \multicolumn{8}{|c|}{ Shale Gas } \\
\hline & \multicolumn{2}{|c|}{ Source Potential } & \multicolumn{3}{|c|}{ Migration } & \multicolumn{2}{|c|}{ Seal } \\
\hline Whangai Fm & \multicolumn{2}{|c|}{$\begin{array}{l}\text { Mature, gas and oil prone, ave } \\
\text { TOC } 1.5 \% \text {, overpressured. }\end{array}$} & \multicolumn{3}{|c|}{$\begin{array}{l}\text { Hydraulic fracturing due to high capillary } \\
\text { pressure, likely near-to-source hydrocarbon } \\
\text { charge through laminated facies. }\end{array}$} & \multicolumn{2}{|c|}{ Hydraulic seal failure. } \\
\hline Kurinui Fm & \multicolumn{2}{|c|}{$\begin{array}{c}\text { Immature, gas prone, ave TOC } \\
1.3 \% \text {, normally pressured. }\end{array}$} & \multirow{2}{*}{\multicolumn{3}{|c|}{$\begin{array}{l}\text { Possible hydraulic fracturing due to localised } \\
\text { elevated capillary pressure, likely near-to- } \\
\text { source hydrocarbon charge through laminated } \\
\text { facies. }\end{array}$}} & \multirow{2}{*}{\multicolumn{2}{|c|}{$\begin{array}{l}\text { Possible hydraulic or membrane } \\
\text { seal failure. }\end{array}$}} \\
\hline Moeraki Fm & \multicolumn{2}{|c|}{$\begin{array}{l}\text { Immature gas and oil prone, ave } \\
\text { TOC } 1.5 \% \text {, normally pressured. }\end{array}$} & & & & & \\
\hline \multicolumn{8}{|c|}{ Basin Centred Gas Systems } \\
\hline & $\begin{array}{c}\text { Permeability } \\
\text { \& Porosity }\end{array}$ & $\begin{array}{c}\text { Spatial } \\
\text { Dimensions }\end{array}$ & $\begin{array}{c}\text { Formation } \\
\text { Pressure }\end{array}$ & $\begin{array}{c}\text { Hydrocarbon } \\
\text { Type }\end{array}$ & $\begin{array}{c}\text { TOC } \\
\text { (ave } \%)\end{array}$ & $\begin{array}{c}\text { Trapping } \\
\text { mechanism }\end{array}$ & Depth \\
\hline Monterey Fm & $\begin{array}{l}0.1-10 \mathrm{md} \& \\
\text { up to } 20 \% \text { in } \\
\text { fractured } \\
\text { shale }\end{array}$ & $80,000 \mathrm{~km}^{2}$ & $\begin{array}{l}\text { Under- } \\
\text { pressured to } \\
\text { normal }\end{array}$ & II & $5 \%$ & $\begin{array}{l}\text { Mainly structural } \\
\text { with several } \\
\text { stratigraphic } \\
\text { pinchout traps }\end{array}$ & c.a. $4.0 \mathrm{~km}$ \\
\hline Kurinui Fm & Unknown & $\begin{array}{c}\text { At least } \\
50,000 \mathrm{~km}^{2}\end{array}$ & $\begin{array}{l}\text { Normally } \\
\text { pressured }\end{array}$ & II & $1.3 \%$ & Stratigraphic & c.a. 2100 \\
\hline Moeraki Fm & Unknown & $\begin{array}{c}\text { At least } \\
50,000 \mathrm{~km}^{2}\end{array}$ & $\begin{array}{l}\text { Normally } \\
\text { pressured }\end{array}$ & II/III & $1.5 \%$ & Stratigraphic & c.a. 2500 \\
\hline
\end{tabular}

Table 7.1: Shale Gas \& BCGS Summary Table: East Coast New Zealand and Californian analogues

\subsubsection{The Whangai Formation}

Fine grained Paleogene transgressive deposits are contained in the East Coast Basin are similar to Paleogene sediments in the Canterbury Basin. They were deposited in a large passive margin during the late Cretaceous to late Paleogene (c.a. $85 \mathrm{Ma}$ to $25 \mathrm{Ma}$ ), and include significant source rocks belonging to the Whangai and overlying Waipawa formations. Basement rocks comprise Jurassic to Cretaceous aged low-grade metamorphosed sediments derived from the Gondwana Super Continent (Uruski, 2010).

The Whangai Formation is of late Cretaceous to early Paleogene (Haumurian to Teurian) age, and is between 300 and $500 \mathrm{~m}$ thick throughout much of the onshore East Coast Basin. It is siliceous mudstone exhibiting silica weight percentages up to $83 \%$ which is considered very high by Moore (1988) and indicative of a shale rock (Retallack, 2001). The Whangai Formation is a known hydrocarbon source leaking oil to the surface in a number of seeps throughout the East Coast (Rogers et al., 1999).

The Whangai Formation may actually exhibit the requisites of a shale gas system; 1) source; 2) reservoir; and 3) seal rocks:

1. Average TOC source rock values of the Whangai Formation are in the order of $1 \%$ with maximum measured TOC values of 1.5\% (Moore, 1988; Uruski, 2010). Similar TOC source rock values measured from Clipper Sub-Basin samples (Moeraki and Kurinui formations) range between $1.04 \%-1.66 \%$ (Section 5.4). These are equally as low values, but remain significant enough to produce gas (Peters \& Cassa, 1994). 
2. The second requisite is reservoir. In both the East Coast and Canterbury Basins, suspected reservoirs are compositionally similar. In the Canterbury Basin, the Katiki and overlying Moeraki Formation are similar to the Whangai Formation. The Whangai Formation is a highly bioturbated, moderately to poorly sorted mudstone, mainly comprising detrital quartz (Figure 5.4) with greensand and well bedded calcareous facies. XRD analysis used in the study to determine the fine grained composition of Clipper Sub-Basin mudstones illustrates relatively high smectite values ranging between $0-32.6 \%$ (Figure 5.6).

3. Mudstones deposited during maximum marine flooding, observed in the Paleocene - Eocene record throughout New Zealand, also share a distinct high smectite signature (Darby, 2002). This is significant to the reservoir quality as Dewhurst et al., (1999), and Alpin \& Macquaker, (2010) suggest smectite rich mudstones generally have very low permeability properties, and tend to become overpressured.

4. The final requisite of a shale gas play and perhaps the hardest to compare and quantify for these contiguous mudstones, is the seal rock capacity. Little work has been undertaken in the seal rock behaviour in the East Coast and Canterbury Basins. According to Darby \& Funnell, (2001), seal rock properties in the East Coast Basin have compromised overpressured source rocks (e.g. Whangai, Waipawa Black Shale and Wanstead Formations). Hydraulic failure is likely to have occured whereby the capillary pressure is so high that the seal preferentially fails by fracturing allowing hydrocarbon to escape (Darby, 2002). Over 300 oil seeps are known to exisit throughout the East Coast Basin (Campbell et al., 2008). Fluid conduits allowing this hydrocarbon to migrate to the surface is thought to occur either by faults, joints, fractures, lateral connectivity, porosity differences associated with unconformable sediments or diapirism (Field et al., 1997). Similar lithologies are observed throughout Dannevirke aged sediments in the Canterbury Basin, in particular the Kurinui and Moeraki formations where hydrocarbon seeps and shows have also been documented throughout the Lindis Pass and Waihao Downs area. Here between 107 and 254 litres of crude oil/tonne have been calculated respectively (McLernon, 1978; Field and Browne, 1989).

\subsubsection{The Monterey Formation}

The Monterey Formation is located along the Californian coast in the Santa Maria Basin. Late Oligocene to early Miocene transform and extensional faulting along the Californian margin caused the subsidence and resulting infilling of Monterey sediments. This is a heterolithic formation that comprises varying amounts of biogenic calcite (calcareous nannofossils and foraminifera) and biogenic silica (radiolarian and diatoms) deposited in thick beds of mudstone and subordinate sandstone. The Monterey Formation is strongly fractured (Eichhubl \& Boles, 2000). Commonly 700m thick (and known to measure up to 
$1400 \mathrm{~m}$ thick), the Monterey Formation is a producing hydrocarbon system, which also exhibits the requisites of a known BCGS; 1) low permeability; 2) abnormal pressure; 3) gas saturated; and 4) regionally pervasive accumulations.

This is now described with reference to Dannevirke aged sediments of the Clipper Sub-Basin:

1. The permeability of the Monterey Formation varies between $0.1-10 \mathrm{md}$, while porosity values range between $1-5 \%$ in fractured lithologies and $10-20 \%$ in the low permeability matrix (Eichhubl \& Boles, 2000). Although exhibiting low porosity values, these fractures have developed after silica diagenesis occurred. This is significant as micro-fractures connect the pore spaces, and fracture permeabilities can be very high, in the order of 10's of Darcy's (Bodnar, 1990). They are subsequently important hydrocarbon conduits which comprise varying amounts of carbonate and minor silica cement. Fluid flow in fractured siliceous mudstone is likely to occur through highly localised faults that are associated with extensive subordinate fractures. These fractures are orientated orthogonal to bedding and usually strike perpendicular to $\mathrm{Sh}_{\max }$ directions, as is the case in the Canterbury Basin (Figure 6.6). There is no analytical data for Dannevirke aged mudstones in the Clipper Sub-Basin so comparison here is difficult.

2. It is unclear what the precise pressure regime for the entire Monterey Formation is, although Popov et al., (2000) suggest unconventional gas is sourced from underpressurised Miocene units. Modular formation dynamics test (MDT) data from Cutter-1 suggests the Dannevirke Series mudstones are normally pressured between c.a. 2000 - 3000mbrt, with slight deviation away from this linear trend (c.a. $7 \mathrm{MPa} / 500 \mathrm{~m}$ ) between c.a. $2522-2531 \mathrm{mbrt}$ where formation pressure dropped from an average of $28 \mathrm{MPa}$ to a $25 \mathrm{MPa}$. This corresponds to gas shows observed in the Moeraki Formation.

3. Offshore fields of the Monterey Formation produce heavy oil, with gravities ranging from less than 5 to as light as $40^{\circ}$ API (Popov et al., 2000). Onshore basin oils within the Monterey Formation have low gravities ranging from 16 to $27^{\circ} \mathrm{API}$, and high sulphur and nitrogen content. Natural gas comprises only a small portion of the hydrocarbons. The gas occurs as solution gas or, rarely, as gas caps. Little is known about natural gas occurring in the Dannevirke Series mudstones, other than it is wet gas (i.e. >IC4).

4. Net reservoir thickness averages $300 \mathrm{~m}$ and ranges from 15 to $1000 \mathrm{~m}$ in the Monterey Formation. Anticlines that formed above major reverse faults have trapped most oil and gas accumulation within the basin. Only one significant non-structural field has a trap formed by a stratigraphic pinchout (Popov et al., 2000). Dannevirke aged mudstones in the Clipper Sub-Basin range between c.a. $530-1100 \mathrm{~m}$ thick with suspected reservoir thicknesses up to $70 \mathrm{~m}$ (Cutter-1). These 
mudstones represent regional scale deposition which drapes Cretaceous sandstones throughout the east coast of New Zealand (Field \& Browne, 1989; Field \& Uruski, 1997; and Cook et al., 1999).

\subsubsection{Summary}

Dannevirke aged mudstones from the Clipper Sub-Basin illustrate no visible porosity in thin section (Section 5.1). The observed gas accumulation (in Cutter-1) has possibly migrated from Cretaceous sandstones (Section 5.4). Associated with increased gas generation, expulsion, and migration, gas begins to enter adjacent, water-wet sandstones such as the lower Katiki or Herbert Formation. Because these sandstones have low permeability which are in the order of $1-100 \mathrm{md}$ (Wilson, 1985), the rate at which gas is generated and accumulated in these clastic reservoirs is greater than the rate at which gas is lost. It is proposed, this newly generated gas accumulates in the sandstone or laminated mudstone pore system. When the capillary pressure of the water-wet pores is exceeded, and free, mobile water is expelled from the pore system, the development of an overpressured, gas-saturated reservoir with little or no free water occurs.

\subsection{Enhancing Porosity in Mudrock}

Findings made in this research indicate accumulation of free gas can occur in laminated mudstone. Gas saturation of mudstone intervals in the Clipper Sub-Basin occur in silica rich facies. According to Pye \& Krinsley, (1985); Hornby et al., (1994); Gale et al., (2007); and Thyberg et al., (2010), elevated quartz abundance can enhance intergranular porosity and by linking porous zones together; the permeability of the rock is enhanced. Silica diagenesis and grain dissolution re-order and redistribute silica concentrations; and when in great enough abundance, create a relative brittle-to-ductile lithology contrast. Gas migration along faults and microfractures is likely to be controlled by pre-existing structural defects (e.g. igneous upwelling or faulting), which will enhance zones of relative brittle weakness. This occurs in much the same way a crack on the surface of a frozen lake will propagate from its source of inception when stressed.

Quartz is a hard and brittle mineral (Bisschop et al., 2005). It displays poor ductile properties and when stressed is likely to fracture. Continued development and displacement of the Alpine and related faults west of the Canterbury Basin during the Neogene and reactivation of underlying Paleogene and Cretaceous faults might provide conduits for hydrocarbon migration. FMI image logs indicate drilling induced and natural fracturing with $\mathrm{Sh}_{\max }$ and $\mathrm{Sh}_{\min }$ stress directions aligned normal to the AustralianPacific plate boundary. This could be related to reactivation of Cretaceous faults at depth but extending into Paleogene sediments, or at least creating clusters of micro scale fractures.

A second mechanism capable of displacing and fracturing brittle lithology in the Clipper Sub-Basin is the upwelling by underlying plutonic intrusions. Intrusions of this nature are noted throughout the central and 
southern Canterbury Basin seismic records (Shell BP Todd Canterbury Services Ltd, 1984d). Vertical displacements, over pressuring of lithological units and brittle failure of overlying lithology might have resulted in structures as indicated in Figure 2.3 E. 



igure 7.1: Canterbury Basin: Fault and igneous induced deformation of Paleges surb

The volcanic intrusives underlying the Galleon and Barque prospects in illustration (beneath) have clearly punched through or reduced the Clipper and Katiki Formation thickness. This has created stress upon the overlying Hampden-Kurinui-Moeraki reactivation of Cretaceous faults may have developed into overlying Paleocene to Oligocene drape deposits. Both mechanisms cause planes of failure which when charged will act as hydrocarbon conduits (or leaky seals) from Cretaceous aged reservoirs into the overlying Paleocene to Eocene aged mudstones of the Dannevirke Series. Both images are modified after NZOG confidentia 


\subsection{Silica Diagenesis}

Although the concept of brittle failure in siliceous rock and subsequent fracturing has been addressed, the actual means of quantifying this hypothesis are complex and outside the scope of this study. Attention is therefore focused on determining the nature of silica abundance in well cutting samples from within the Clipper Sub-Basin. Of immediate interest are the reasons why abundant silica is forming in recognisable intervals throughout a predominantly calcareous mudstone succession. Consistently high siliceous productivity is recorded in the late Cretaceous and Paleocene record throughout the southwest Pacific Ocean, in particular the Whangai Formation of the East Coast Basin.

Only rare radiolarian populations were noted in the Dannevirke record at Hampden Beach by Morgans (2009), while no such radiolaria were observed in the four Clipper Sub-Basin wells examined. Silica diagenesis from other minerals is therefore considered the most likely source for the locally elevated silica levels. Diagenetic changes throughout the early Dannevirke Series mudrocks in the Clipper Sub-Basin include the formation of carbonate cement, alteration of mica, various clay minerals, pyrite and silica transformations. Temperature, pressure, pore fluid chemistry, burial and depositional history each play significant roles in rock composition. Siliceous sediments deposited in marine environments are mainly biogenic in origin (e.g. abundant diatom and radiolarian populations) and are considered as amorphous opal (Opal-A) when identified in great abundance in the fossil record. With ongoing diagenesis, major crystalline re-ordering occurs, which essentially completes a transformation from amorphous opal, to disordered cristobalite (opal-CT), and finally to quartz. Factors such as clay to carbonate ratios, temperature and pressure regimes control this rate of change, whereby rapid change can occur under elevated temperatures and suitable chemical conditions. Opal-CT to quartz transformations are very slow and dependant of high temperatures and alkaline pore solutions (Moore, 1988). Such transformations are documented by Moore (1988) in the Whangai Formation (Haumurian to Teurian). Moore favours a complete silica diagenesis transformation from opal-A or opal-CT to microcrystalline quartz, which is measured in values up to $83 \%$ Si02 by weight.

Sufficiently high temperatures and pressure conditions must have occurred during diagenesis for biogenic or detrital silica to be entirely converted to quartz. Moore (1988) reasons that past maximum formation temperatures experienced in the Whangai Formation were in the order of $55-60^{\circ} \mathrm{C}$, which is sufficient enough to alter the silica to quartz. If a similar scenario in the Canterbury Basin has occurred, an adequate heat source is required. As discussed in Section 3 an elevated thermal gradient by means of extrusive volcanics are likely to have locally raised ambient temperature regimes. Downhole temperature measurements and vitrinite reflectance data from Clipper Sub-Basin wells indicate that past and present temperatures in the order of $65-75^{\circ} \mathrm{C}$ exist. The lack of a biosiliceous origin that offer the silica (based on SEM work) and the presence of highly crystalline XRD diffraction patterns (presented in Section 5.2) are major findings in this thesis. 


\subsection{Depositional Processes}

Equivalent siliceous mudrocks are common throughout east coast New Zealand. These are the Conway, Herring and Mirza Formations in Northern Canterbury and Marlborough areas, and the Kurinui and Moeraki Formations in Central Canterbury Basin and the Garden Grove Formation i n the Great South Basin (Moore, 1988). This suggests a compositional similarity between these areas where slowly subsiding basins were coincident with a reduced supply of course terrigenous sediment. In most instances the areas were associated with biosiliceous sedimentation. As discussed in Section 7.4, silica rich mudrock facies appear to have been deposited throughout the south west Pacific during Cretaceous Paleocene biosiliceous upwelling events. Compositional similarities over such large areas cannot be attributed to any particular enclosed basin or offshore barrier. Therefore restricted oceanic circulation during the Cretaceous - Paleocene and biosiliceous upwelling events are likely to have caused siliceous facies in the regions.

A particular observation was made during analysis of the FMI data from Cutter-1, whereby a laminated interval corresponded to a highly siliceous interval in the gas saturated upper Kurinui Formation (2142.8 2213 mbrt). The average dip angle observed in this interval was only $2^{\circ}$; noticeably less than the underlying structural zones picked when constructing a dip azimuth walkout plot (Figure 6.4). This would suggest gas cannot accumulate where inclined strata allows up dip hydrocarbon losses. 


\subsection{Conclusions}

\subsection{Introduction}

Petroleum is the most critical energy resource for modern economies, supplying about $40 \%$ of the world's primary energy and nearly all of the fuel for the world's transportation systems (Greene et al., 2006). Over the past 30 years, world hydrocarbon use has increased by $47 \%$ despite oil price shocks and economic downturns. Over the next 30 years hydrocarbon demand is expected to grow by $60 \%$ as the transportation systems of developing economies become increasingly motorised (Greene et al., 2006). This growing reliance on hydrocarbon fuels and the continuing lack of economical substitutes for petroleum based transportation fuels has generated concern about the future adequacy of the world's petroleum resources.

There is increasing certainty that conventional oil production has peaked or will peak before 2025 (Mohr \& Evans, 2010). Given the likely peak in conventional oil production, it is important to examine unconventional hydrocarbon resources and possible production. The question therefore to be addressed, assuming conventional oil production will peak before 2025 , is what role can unconventional hydrocarbon play?

Largely overlooked by the 'traditional' or conventional oil and gas industry in New Zealand, neither finegrained sediments nor Dannevirke Series rocks of the Canterbury Basin have figured prominently in previous assessments of unconventional hydrocarbon potential.

\subsection{Project Achievements}

The intention of this thesis was to assess the potential and type the unconventional gas system which may exist in Dannevirke aged (65-43Ma) mudstone in the Canterbury Basin, South Island, New Zealand. This was achieved by examining data from wireline logs, and analytical laboratory testing.

Known or suspected gas-charged intervals were identified using wireline gas chromatography and logs. Cutting samples were collected from zones of interest and subjected to an analytical laboratory test programme.

By investigating Dannevirke aged sediments, this study has;

1. Found Dannevirke aged mudstone samples from four Clipper Sub-Basin wells classify as sublitharenite when plotted on a Quartz-Feldspar-Lithic plot. Quartz rich facies are a product of silica diagenesis altered from weathered Haast Schist and volcanic intrusions, or biosiliceous radiolarian or diatoms.

2. Observed intermittent gas saturation occurs where decreased gamma, resistivity, and density wireline values correspond to increased limestone porosity and total gas readings. Fissile or finely 
laminated shale lithology is suspected to accommodate lateral near-to-source hydrocarbon conduits, saturating relatively porous bedding with wet gas.

3. Confirmed gas-prone fissile or finely laminated lithology is quartz-high and clay-poor in composition, exhibiting up to $72 \mathrm{wt} \%$ quartz.

4. Confirmed gas-prone, quartz dominant, laminated facies correspond to concentrated natural fracture frequency. Resistive fractures observed during FMI log interpretation predominantly aligning to a $\mathrm{Sh}_{\min } \mathrm{SW}-\mathrm{NE}$ direction in Cutter-1; an orientation consistent with other regional findings.

5. Dannevirke aged sedimentation in Cutter-1 has a low but not insignificant source rock potential. Measured TOC values are all under $1.7 \%$ and are considered gas-prone and immature. Gaseous intervals identified in Cutter-1 are considered to be a near-to-source gas charge or in-situ biogenic gas accumulation.

6. Given the above, the Clipper Sub-Basin may constitute the workings of a direct type BCGS.

\subsection{Implications for hydrocarbon prospectivity}

Traditionally, hydrocarbon exploration in the Canterbury Basin has targeted Cretaceous clastic reservoirs with the younger Dannevirke aged sediments regarded as a secondary target. The Dannevirke Series provides a laterally pervasive mudstone succession between c.a. $530-1100 \mathrm{~m}$ thick. Six formations are recognised within the Dannevirke Series, which comprise finely laminated to massive mudstone facies. Subordinate siliceous facies appear in discrete intervals throughout the Clipper Sub-Basin wells examined. These intervals exhibit quartz rich-clay poor characteristics, which are horizontally well laminated, alternating clay, silt and fine sand beds. These siliceous facies are gas-charged and reflect either migration conduits from leaking Cretaceous reservoirs or zones of biogenic or thermogenic hydrocarbon accumulation, up to $70 \mathrm{~m}$ thick. Fracturing of these ultra-low porosity and permeability rocks would appear to be a strong factor controlling wet gas shows in Dannevirke aged mudstones. This notion is semi-qualified by an elevated gas chromatograph to elevated silica relationship throughout the Clipper Sub-Basin, particularly in the Kurinui, Moeraki and Katiki formations. Near-to-source vertical or lateral hydrocarbon conduits forming through brittle fractures of siliceous rock or intervals of finely laminated shale are doing so possibly from underlying leaking Cretaceous aged formations. Galleon-1 measured up to $10.1 \mathrm{mmscf} / \mathrm{d}$ gas and $2300 \mathrm{bbls} / \mathrm{d}$ of condensate from a $21 \mathrm{~m}$ thick zone of net pay in late Cretaceous sandstones, as did Clipper-1 with gas and condensate shows over at $18.5 \mathrm{~m}$ thick interval of net pay. 
Knowledge gained from this research has provided some insights into the type of unconventional hydrocarbon considered possible in Dannevirke aged mudstones of the Clipper Sub-Basin. In this study, the extent of known or suspected gas-charged siliceous facies was defined by wireline logs and subsequent laboratory testing. These gas-charged facies may provide economically sufficient wet gas accumulations if directionally drilled, particularly through siliceous facies which are prone to fracture propagation.

\subsection{Future work}

Many aspects of unconventional gas accumulation in the Clipper Sub-Basin remain unresolved. Future work concerning rock mechanics and organic geochemistry is required, which may include:

1. Mercury Injection Capillary Pressure (MICP) tests; and

2. Uniaxial confined compression (UCC) tests.

Results from MICP tests will give insight into the ability of Dannevirke aged mudstones to retain hydrocarbon leaking from Cretaceous reservoirs. UCC tests will quantify principal stress values required to fracture siliceous mudstone, allowing better determination of suspected fracture conduits. Stable isotope analysis of an actual gas sample would have determined the provenance of recorded downhole gas. If gas has migrated, it would have done so by controlling factors as determined by MICP and UCC testing. The ability or need to undertake this proposed work depends on evidence supporting an unconventional hydrocarbon play in the Clipper Sub-Basin. Evidence can only be obtained by drilling more exploration wells, through Dannevirke aged mudstones. 


\subsection{References}

Abercrombie, H. J., Hutcheon, I. E., Bloch, J. D., \& de Caritat, P. (1994). Silica Activity and the smectiteillite reaction. Geology , 22 (6), 539-542.

Adams, C. J., Campbell, H. J., Graham, I. J., \& Mortimer, N. (1998). Torlesse, Waipapa and Caples suspect terranes of New Zealand: Intergrated studies of their geological history in relation to neighbouring terranes. Journal of International Geoscience , v. 21 (4), p. 235 - 240.

Allen, P. A., \& Allen, J. R. (2005). Basin Analysis; Principles and Applications. Oxford: Blackwell Publishing, p.506.

Alpin, A. C., \& Macquaker, J. H. (2010). AAPG/Data Pages - Getting started Series. In AAPG, Getting Started in Shales (Vol. 20).

Armstrong, H. A., \& Braiser, M. D. (2005). Microfossils. Oxford: Blackwell Publishing, p.304.

Balfour, N. J., Savage, M. K., \& Townend, J. (2005). Stress and crustal anisotropy in Marlborough, New Zealand: evidence for low fault strength and structure-controlled anisotropy. Geophysics Journal International , v. 163, p. 1073-1086.

Bishop, D. G., Bradshaw, J. D., \& Landis, C. A. (1985). Provisional terrane map of South Island, New Zealand. Circum-Pacific Council for Energy Minerals and Earth Sciences Series 1. Houston .

Bisschop, J., den Brok, B., \& Miletich, R. (2005). Brittle deformation of quartz in a diamond anvil cell. Journal of Structural Geology , 27 (6), 943-947.

Bjorlykke, K., \& Hoeg, K. (1997). Effects of burial diagenesis on stresses, compaction and fluid flow in sedimentary basins. Marine and Petroleum Geology , v. 14 (3), p. 267-276.

Bodnar, R. J. (1990). Petroleum Migration in the Miocene Monterey Formation, California, USA: constraints from fluid-inclusion studies. Mineralogical Magazine , v. 54, p. 295-304.

Bowker, K. A. (2007). Barnett Shale gas production, Fortworth Basin: Issues and Discussion. AAPG Bulletin , v. 91, p. 523-533.

Boyer, C., Kieschnick, J., Suarez-Rivera, R., Lewis, R. E., \& Waters, G. (2006, Autumn). Producing Gas from its Source. Retrieved December 2009, from http://www.slb.com/:

http://www.slb.com/media/services/resources/oilfieldreview/ors06/aut06/producing_gas.pdf

Browne, G. H., \& Naish, T. R. (2003). Facies development and sequence architecture of a late Quaternary fluvial-marine transition, Canterbury Plans and shelf, New Zealand; implications for forced regressive deposits. Sedimentary Geology , v. 158 (1-2), p. 57-86.

Burford, R. (1975). Canterbury Basin - New Zealand, degree of organic diagenesis and source rock potential in Endeavour-1 well and Pitt Island outcrop sediments, unpublished openfile petroleum report 665. Wellington: Crown Minerals, Ministry of Economic Development.

Campbell, H., \& Hutching, G. (2007). In search of ancient New Zealand. Penguin Books, p.239.

Campbell, I. (2009, June/July). An overview of tight gas resources in Australia. p 95-100. 
Campbell, K. A., Francis, D. A., Collins, M., Gregory, M. R., Nelson, C. S., Greinert, J., et al. (2008). Hydrocarbon seep-carbonates of a Miocene forearc (East Coast Basin), North Island, New Zealand. Sedimentary Geology , v. 204 (3-4), p. 83-105.

Carter, R. M. (1985). The mid Oligocene Marshall Paraconformity, New Zealand: Coincident with global eustatic sea level fall or rise? Journal of Geology , v. 93 (3), p. 359-371.

Chaika, C., \& Williams, L. A. (2001). Density and mineralogy variations as a function of porosity in Miocene Monterey Formation oil and gas reservoirs in California. AAPG Bulletin , v. 85 (1), p. 149-167.

Cook, R. A., Sutherland, R., Zhu, H., \& others. (1999). Cretaceous-Cenezoic geology and petroleum systems of the Great South Basin, New Zealand. Institute of Geological and Nuclear Sciences, Monograph 20, p. 190.

Cooper, R. A. (2004). The New Zealand Geological Timescale. Institute of Geological and Nuclear Sciences information series 64 .

Crouch, E. M., \& Brinkhuis, H. (2005). Environmental changes across the Paleocene-Eocene transition from eastern New Zealand: A marine palynological approach. Marine Micropaleontology , v. 56, p. 138160.

Crown Minerals New Zealand. (2009, May). Retrieved January 2010, from Petroleum, Petroleum Basins, Canterbury Basin Map.: http://www.crownminerals.govt.nz/cms/petroleum/petroleum-basins/canterburybasin

Darby, D. (2002). Seal properties, overpressure and stress in the Taranaki and East Coast Basins, New Zealand. New Zealand Petroleum conference proceedings , p 1-10.

Darby, D., \& Funnell, R. H. (2001). Overpressure associated with a convergent plate margin, East Coast Basin, New Zealand. Petroleum Geoscience , v. 7 (3), p. 291-299.

Dart, R. L., \& Zoback, M. L. (1989). Wellbore breakout stress analysis within the central and eastern continental United States. Log Analyst , v. 30, p. 12-25.

Dewhurst, D. N., Yang, Y., \& Aplin, A. C. (1999). Permeability and fluid flow in natural mudstones. In: Aplin, A.C., Fleet, A.J. \& Macquaker, J.H.S. (eds) Muds and Mudstones: Physical and fluid-flow properties. Geological Society Special Publication, p 23-24.

Dickinson, W. R. (1971). Detrital modes of New Zealand Greywackes. Sedimentary Geology , v. 5, p. 3756.

Dow, W. G. (1977). Kerogen studies and geological interpretations. Journal of Geochemical Exploration, v. 7, p. 79-99.

Eichhubl, P., \& Boles, J. R. (2000). Focused fluid flow along faults in the Monterey Formation, coastal California. GSA Bulletin , v. 112 (11), p. 1667-1679.

Field, B. D., \& Browne, G. H. (1989). Cretaceous and Cenozoic Sedimentary Basins and Geological Evolution of the Canterbury Region, South Island, New Zealand. Lower Hutt: New Zealand Geological Survey Basin Studies; 2. New Zealand Geological Survey, p.91. 
Field, B. D., \& Uruski, C. I. (1997). Cretaceous - Cenezoic Geology and Petroleum Systems of the East Coast Region, New Zealand. Institute of Geological and Nuclear Sciences Monograph 19, p.301.

Field, B. D., Crundwell, M. P., Kennett, J. P., King, P. R., Jones, C. M., \& Scott, G. H. (2002). The early Middle Miocene paleoenvironmental setting of New Zealand. Revista Mexicana de Ciencias Geologica , v. 19 (3), p. 242-251.

Field, B. D., Funnell, R., Lyon, G., \& Uruski, C. I. (1998). Fluids, migration systems and diapirism, East Coast North Island, New Zealand. In Water-Rock Interaction: Proceedings of the 9th International conference (pp. p. 313-317). Taupo, New Zealand.

Folk, R. L., Andrews, P. B., \& Lewis, D. W. (1970). Detrital sedimentary rock classification and nomenclature for use in New Zealand. New Zealand Journal of Geology and Geophysics , v. 13, p. 937968.

Fulthorpe, C. S., Carter, R. M., Miller, K. G., \& Wilson, J. (1996). Marshall Paraconformity; a midOligocene record of inception of the Antarctic circumpolar current and coeval glacio-eustatic lowstand? Marine and Petroleum Geology, v. 13 (1), p. 61-77.

Gale, J. F., Reed, R. M., \& Holder, J. (2007). Barnett Shale and their importance for hydraulic fracture treatments. AAPG Bulletin , v. 91 (4), p. 603-622.

Gibbons, M. J., \& Fry, S. (1986). A geochemistry study of the Galleon-1 well, Canterbury Basin offshore New Zealand, unpublished openfile report 1146. Wellington: Crown Minerals, Ministry of Economic Development.

Gibbons, M. J., \& Herridge, K. J. (1984). Maturity and source potential of Clipper-1, Canterbury Basin offshore New Zealand, unpublished openfile report 1044. Wellington: Crown Minerals, Ministry of Economic Development.

Gluyas, J., \& Swarbrick, R. (2006). Petroleum Geoscience. Oxford: Blackwell Publishing, p.376 .

Graham, I. J. (2008). A Continent on the Move. The Geological Society of New Zealand in association with GNS Science, p. 377.

Greene, D. L., Hopson, J. L., \& Li, J. (2006). Have we run out of oil yet? Oil peaking analysis from an optimist's perspective. Energy Policy, v. 34 (5), p. 515-531.

Griffin, A. (2009). Overview of shale gas; exploration and exploitation characteristics and issues based on experience from the United States, and implications to New Zealand. GNS Science Report 2009/70.

Hawkes, P. W., \& Mound, D. G. (1984). Clipper-1 Geological Completion Report. Petroleum Report 1036. Crown Minerals, Ministry of Economic Development, New Zealand.

Heidbach, O., Tingay, M., Barth, A., Reinecker, J., Kurfeb, D., \& Muller, B. (2009). World Stress Map Illustration . GFZ German Research Centre for Geosciences.

Higgs, K. E. (2007a). A Petrographic Study of Sidewall Core Plug Samples, Cutter-1 Canterbury Basin. GNS Science Consultancy Report 07/27.

Higgs, K. E. (2007b). X-Ray Diffraction Analysis, Cutter-1 Canterbury Basin. GNS Science Consultancy Report 07/71. 
Hollis, C. J. (1993). Latest Cretaceous to Late Paleocene radiolarian biostratigraphy: A new zonation from the New Zealand region. Marine Micropaleontology , v. 21 (4), p. 295-327.

Hollis, C. J., Rodgers, K. A., \& Parker, R. J. (1995). Siliceous plankton bloom in the earliest Tertiary of Marlborough, New Zealand. Geology, v. 23 (9), p. 835-838.

Hornby, B. E., Schartz, L. M., \& Hudson, J. A. (1994). Anisotropic effective-medium modelling of the elastic properties of shales. Geophysics , v. 59 (10), p. 1570-1583.

Hyne, N. J. (1991). Dictionary of petroleum exploration, drilling \& production. PennWell Books, p.625.

Jarvie, D. M., Hill, R. J., Ruble, T. E., \& Pollastro, R. M. (2007). Unconventional shale-gas systems: The Mississippian Barnett Shale of the north-central Texas as one model for thermogenic shale-gas assessment. AAPG Bulletin , v. 91 (4), p. 475-499.

Johnson, H., \& Dore, A. G. (2009). Unconventional oil and gas resources and the geological storage of carbon dioxide:overview. Petroleum Geology: From mature basins to new frontiers - Proceedings of the 7th petroleum conference, p. 1061-1063.

Jones, J. B., \& Segnit, E. R. (1971). The Nature of Opal 1. Nomenclature and Constituent Phases. Journal of the Geological Society Australia , v. 18 (1), p. 57-68.

Killops, S. D., Cook, R. A., Sykes, R., \& Boudou, J. P. (1997). Petroleum potential and oil-source correlation in the Great South Basin and Canterbury Basins. New Zealand Journal of Geology and Geophysics , v. 40, p. 405-423.

Killops, S. D., Hollis, C. J., Morgans, H. E., Sutherland, R., Field, B., \& Leckie, D. A. (2000).

Paleoceanographic significance of late Paleocene dysaerobia at the shelf/slope break around New Zealand. Palaeogeography, Palaeoclimatology, Palaeoecology, v. 156 (1-2), p. 51-70.

Laird, M. G. (1993). Cretaceous continental rifts: New Zealand region. In: South Pacific Sedimentary Basin. (P.F. Ballance, Ed) Elsevier Science Publishers, Amsterdam.

Larmer, M. P. (1998). Clay minerals in mudstones of the Taranaki Basin, New Zealand. Geological and Nuclear Sciences Ltd, 98/26, p.62.

Larmer, M. P. (1998). SEM and thin section observations of mudstones from the Taranaki Basin, New Zealand. Geological and Nuclear Sciences Ltd Scientific Report, 98/28, p.12.

Law, B. E. (2002). Basin-centered gas systems. The American Association of Petroleum Geologists , v. 86 (11), p. 1891-1919.

Law, B. E., \& Curtis, J. B. (2002). Introduction to unconventional petroleum systems. The American Association of Petroleum Geologists , v. 86 (11), p. 1851-1852.

Lever, H. (2007). Review of unconformities in the late Eoecene to early Miocene successions of the South Island, New Zealand: Ages, correlations, and causes. New Zealand Journal of Geology and Geophysics , v. 50 (3), p. 245-261.

Lu, H., Fulthorpe, C., \& Mann, P. (2003). Three-dimensional architecture of shelf building sediment drifts in the offshore Canterbury Basin, New Zealand. Marine Geology , v. 193 (1-2), p. 19-47. 
Lu, H., Fulthorpe, C., Mann, P., \& Kominz, M. A. (2005). Miocene-Recent tectonic and climatic controls on sediment supply and sequence stratigraphy: Canterbury Basin, New Zealand. Basin Research , v. 17 (2), p. 311-328.

MacKinnon, T. C. (1983). Origin of the Torlesse and coeval rocks, South Island, New Zealand. Geological Society of America Bulletin , v. 94 (8), p. 976-985.

Magoon, L. B., \& Dow, W. G. (1994). The Petroleum System - From Source to Trap. Geological Society Publishing House, p. 644.

McGonigal, K., \& Di Stefano, A. (2002). Calcareous nannofossil biostratigraphy of the EoceneOligocene transition, ODP Sites 1123 and 1124. Retrieved from http://wwwodp.tamu.edu/publications/181_SR/207/207.htm

McLernon, C. R. (1978). Indications of Petroleum in New Zealand. New Zealand Geological Survey, unpublished open file petroleum report no. 839 .

McMillian, S. (1999). Geology of Northeast Otago: Hampden (J42) and Palmerson (J43). Lower Hutt: Institute of Geological and Nuclear Sciences, Science Report 98/25. 55 p. +2 maps.

Mohr, S. H., \& Evans, G. M. (2010). Long term prediction of unconventional oil production. Energy Policy, v. 38 (1), p. 265-276.

Molnar, P. (2004). Late Cenozoic increase in accumulation rates of terrestrial sediment: How might climate change have affected erosion rates? Annual Review of Earth and Planetary Science , v. 32, p. 6789.

Moore, P. R. (1988). Stratigraphy, composition and environment of deposition of the Whangai Formation and associated Late Cretaceous-Paleocene rocks, eastern North Island, New Zealand. Lower Hutt: New Zealand Geological Survey Bulletin 100.

Morgans, H. E. (2009). Late Paleocene to middle Eocene foraminiferal biostratigraphy of the Hampden Beach section, eastern South Island, New Zealand. New Zealand Journal of Geology \& Geophysics , v. 52, p. 273-230.

Morgans, H. E. (2009). Late Paleocene to middle Eocene foraminiferal biostratigraphy of the Hampden Beach section, eastern South Island, New Zealand. New Zealand Journal of Geology \& Geophysics, Vol. 52: 273-230.

Mortimer, N. (2007). Petrology of Cutter-1 Igneous Rocks 07/41. GNS Science Consultancy Report (at this point is confidential).

Norris, R. J., \& Cooper, A. F. (2000). Late Quaternary slip rates and slip partitioning on the Alpine Fault, New Zealand. Journal of Structural Geology , v. 23 (2-3), p. 507-520.

Peltonen, C., Marcussen, O., Bjorlykke, K., \& Jahren, J. (2009). Clay mineral diagenesis and quartz cementation in mudstones; The effects of smectite to illite reaction on rock properties. Marine and Petroleum Geology , v. 26 (6), p. 887-898.

Peters, K. E., \& Cassa, M. R. (1994). Applied source-rock geochemistry. In: Maggon, L.B., Dow, W.G. (Eds.), The Petroelum System-From Source to Trap. American Association of Petroleum Geologists Memoir , v. 60, p. 93-120. 
Pocknall, D., Raine, I., Strong, P., \& Wilson, G. (1991). Petroleum Report Series PR 1806.

Biostratigraphic revision of Mata \& Dannevirke series (Late cretaceous to early eocene) in Endeavour-1 \& Galleon-1 exploration wells, Canterbury Basin New Zealand PPL 38252. The Ministry of Economic Development.

Popov, M. A., Nuccio, V. F., Dyman, T. S., Gognat, T. A., Johson, R. C., Schmoker, J. W., et al. (2000). Basin Centred Gas Systems of the United States: Open file report OF 01-135. US Department of the Interior, Geological Survey, 1-299.

Pye, K., \& Krinsley, D. H. (1985). Formations of secondary porosity in sandstones by quartz framework grain dissolution. Nature; Letters to Nature , v. 317, p. 54-56.

Raine, J. I. (2008). Zonate lycophyte spores from New Zealand Cretaceous to Paleogene strata. Journal of Palaeontology , v. 32 (2), p. 99-127.

Raine, J. I., \& Schioler, P. (2007). Cretaceous to Eocene Biostratigraphy of Cutter-1 Well. GNS Science Consultancy Report 07/71 (at this point is confidential).

Retallack, G. J. (2001). Soils of the Past (2nd ed.). Oxford: Blackwell Science Ltd, p.512.

Rider, M. H. (2002). The Geological Interpretation of Well Logs. Sutherland, Scotland: Whittles Publishing, 2nd Edition, p. 288.

Rogers, K. M., Collen, J. D., Johnston, J. H., \& Elgar, N. E. (1999). A geochemical appraisal of oil seeps from East Coast Basin, New Zealand. Organic Geochemistry, v. 30 (7), p. 593-605.

Ross, D. J., \& Bustin, R. M. (2008). Characterizing the shale gas resource potential of DevonianMississippian strata in the Western Canada sedimentary basin: Application of an integrated formation evaluation. AAPG Bulletin , v. 92 (1), p. 87-125.

Schiøler, P., Rogers, K., Sykes, R., Hollis, C. J., Ilg, B., Meadows, D., et al. (2010). Palynofacies, organic geochemistry and depositional environment of the Tartan Formation (Late Paleocene), a potential source rock in the Great South Basin, New Zealand. Marine and Petroleum Geology , v. 27 (2), p. 351-369.

Schiøler, P., Roncaglia, L., Morgans, H. E., Raine, J. I., Strong, C. P., \& Wilson, G. J. (2007). Revised biostratigraphy and well correlation, Great South Basin, New Zealand. GNS Science Consultancy Report $08 / 01$.

Schmoker, J. W. (2002). Resource-assessment perspectives for unconventional gas systems. The American Association of Petroleum Geologists , v. 86 (11), p. 1993-1999.

Selley, R. C. (1998). Elements of Petroleum Geology. London: Academic Press.

Shell BP Todd Canterbury Services Ltd. (1984b). Petroleum Report Series PR 1012. Final report of operational \& field work marine seismic survey Canterbury Bight PPL 38023. The Ministry of Economic Development.

Shell BP Todd Canterbury Services Ltd. (1984c). Petroleum Report Series PR 1036. Well Completion Report, Clipper-1. The Ministry of Economic Development.

Shell BP Todd Canterbury Services Ltd. (1984d). Petroleum Report Series PR 1046. Interpretation and prospectivity of PPL 38203 Canterbury Basin New Zealand. The Ministry of Economic Development. 
Shell BP Todd. (1984a). Interpretation and prospectivity of PPL 38203 Canterbury Basin, New Zealand. New Zealand unpublished openfile petroleum report 1046. Crown Minerals, Ministry of Economic Development, Wellington.

Shelley, D. (1975). Optical Mineralogy (Second Edition ed.). Department of Geology, University of Canterbury Christchurch, New Zealand, 2nd Edition, p.352.

Smale, D., Jeffrey, M. L., Palmer, J., Soong, R., \& Blattner, P. F. (1999). Variations in sandstone diagenesis with depth, time, and space, onshore Taranaki wells, New Zealand. New Zealand Journal of Geology and Geophysics , v. 42 (2), p. 137-154.

Spencer, C. W. (1997). Describing Petroleum Reservoirs of the Future. Retrieved 2011, from United States Geological Survey: http://energy.usgs.gov/factsheets/Petroleum/reservoir.html

Suggate, R. P. (1990). Late Pliocene and Quaternary glaciations of New Zealand. Quarternary Science Reviews , v. 9 (2-3), p. 175-197.

Sutherland, R. (1999). Cenozoic bending of New Zealand basement terranes and Alpine Fault displacement: a brief view. New Zealand Journal of Geology and Geophysics , v. 42, p. 295-301.

Sutherland, R., Zhu, H., Funnell, R., Thorton, S., Hill, M., \& Cook, R. (2002). The Great South Basin, New Zealand: a regional study of basin structure, source and reservior rock distribution, and quantitative models of hydroarbon generation. Lower Hutt.

Sykes, R. (2004). Peat Biomass and early diagenetic controls on the paraffinic oil potential of humic coals, Canterbury Basin, New Zealand. Petroleum Geoscience, v. 10, p. 283-303.

Sykes, R., \& Funnell, R. H. (2002). Petroleum Source Rock Potential and Generation History in the Offshore Canterbury Basin. Institute of Geological \& Nuclear Sciences client report 44.

Tap Oil Limited. (2007 ). Cutter-1. Well Completion Report - Basic Data. Drilling, Engineering and Geological Data. (at this point is confidential).

The Economist. (2010, March). An Unconventional Glut.

Thyberg, B., Jahren, J., Winje, T., Bjorlykke, K., Faleide, J. I., \& Marcussen, O. (2010). Quartz cementation in Late Cretaceous mudstones, northern North Sea: Changes in rock properties due to dissolution of smectite and precipitation of micro-quartz crystals. Marine and Petroleum Geology , v. 27 (8), p. 1752-1764.

Tissot, B. P., \& Welte, D. H. (1978). Petroleum Formation and Occurrence. A new approach to oil and gas exploration. Springer-Verlag Berlin Heidelberg, p. 538.

Uruski, C. I. (2010). New Zealand's Deepwater Frontier. Marine and Petroleum Geology , v. 27 (9), p. 2005-2026.

US Information Administration. (2010). Retrieved from Independant Statistics and Analysis: http://www.eia.doe.gov/oil_gas/natural_gas/special/ngresources/ngresources.html

Velde, B. (1983). Diagenetic Reactions in Clays. Netherlands: D.Reidel Publishing.

Welton, J. E. (1984). SEM Petrology Atlas. The American Association of Petroleum Geologists, p. 237. 
Wilson, G. J., \& McMillan, S. G. (1996). Late Cretaceous - Tertiary Stratigraphic Sections of Coastal Otago, South Island, New Zealand: a summary of biostratigraphic and lithostratigraphic data. Institute of Geological and Nuclear Sciences Report 96/39, p.189.

Wilson, I. R. (1985). Galleon-1 Well Completion Report. Petroleum Report 1146. Crown Minerals, Ministry of Economic Development, New Zealand.

Wood, R. A., Andrews, P. B., \& Herzer, R. H. (1989). Cretaceous and Cenozoic Geology of the Chatham Rise Region, South Island, New Zealand. Lower Hutt: New Zealand Geological Survey Basin Studies; 3. New Zealand Geological Society, p.108. 
Appendix A: New Zealand Geological Timescale 


\begin{tabular}{|c|c|c|c|c|c|c|c|}
\hline \multicolumn{8}{|c|}{ After Cooper, (2004) } \\
\hline Era & System & Series & Series & Stage & Symbol & $\begin{array}{c}\text { Age of } \\
\text { base, Ma }\end{array}$ & $\begin{array}{c}\text { Duration, } \\
\text { Ma }\end{array}$ \\
\hline \multirow{25}{*}{$\begin{array}{l}\text { O } \\
\text { N } \\
\text { O } \\
\text { U. }\end{array}$} & \multirow{3}{*}{ Quaternary } & Holocene & \multirow{7}{*}{ Wanganui Series } & \multirow{2}{*}{ Haweran } & \multirow{2}{*}{ Wq } & & \\
\hline & & \multirow[b]{2}{*}{ Pleistocene } & & & & 0.34 & 0.34 \\
\hline & & & & Castlecliffian & Wc & 1.63 & 1.29 \\
\hline & \multirow{11}{*}{ Neogene } & \multirow{4}{*}{ Pliocene } & & Nukumaruan & $\mathrm{Wn}$ & 2.4 & 0.77 \\
\hline & & & & Mangapanian & $\mathrm{Wm}$ & 3.03 & 0.63 \\
\hline & & & & Waipipian & $W p$ & 3.6 & 0.57 \\
\hline & & & & Opoitian & Wo & 5.28 & 1.68 \\
\hline & & \multirow{7}{*}{ Miocene } & \multirow[t]{2}{*}{ Taranaki Series } & Kapitean & Tk & 6.5 & 1.22 \\
\hline & & & & Tongaporutuan & $\mathrm{Tt}$ & 11.0 & 4.5 \\
\hline & & & \multirow{3}{*}{ Southland Series } & Waiauan & Sw & 13.2 & 2.2 \\
\hline & & & & Lillburnian & $\mathrm{SI}$ & 15.1 & 1.9 \\
\hline & & & & Clifdenian & Sc & 16.0 & 0.9 \\
\hline & & & \multirow{2}{*}{ Pareora Series } & Altonian & $\mathrm{PI}$ & 19.0 & 3 \\
\hline & & & & Otaian & Po & 21.7 & 2.7 \\
\hline & \multirow{11}{*}{ Paleogene } & \multirow{3}{*}{ Oligocene } & \multirow[t]{3}{*}{ Landon Series } & Waitakian & $\mathrm{Lw}$ & 25.2 & 3.5 \\
\hline & & & & Duntroonian & Ld & 27.3 & 2.1 \\
\hline & & & & Whaingaroan & Lwh & 34.3 & 7 \\
\hline & & \multirow{7}{*}{ Eocene } & \multirow{3}{*}{ Arnold Series } & Runangan & $\mathrm{Ar}$ & 35.8 & 1.5 \\
\hline & & & & Kaiatan & $\mathrm{Ak}$ & 37.0 & 1.2 \\
\hline & & & & Bortonian & $\mathrm{Ab}$ & 43.0 & 6 \\
\hline & & & \multirow{5}{*}{ Dannevirke Series } & Porangan & $\mathrm{Dp}$ & 46.2 & 3.2 \\
\hline & & & & Heretaungan & $\mathrm{Dh}$ & 49.5 & 3.3 \\
\hline & & & & Mangaorapan & $\mathrm{Dm}$ & 53.0 & 3.5 \\
\hline & & & & Waipawan & Dw & 55.5 & 2.5 \\
\hline & & Paleocene & & Teurian & $\mathrm{Dt}$ & 65.0 & 9.5 \\
\hline \multirow{16}{*}{$\begin{array}{l}\text { O } \\
\text { N } \\
\text { On } \\
\text { W }\end{array}$} & \multirow{10}{*}{ Cretaceous } & & \multirow{2}{*}{ Mata Series } & Haumurian & $\mathrm{Mh}$ & 84.5 & 19.5 \\
\hline & & & & Piripauan & $\mathrm{Mp}$ & 86.5 & 2 \\
\hline & & & \multirow{3}{*}{ Raukumara Series } & Teratan & $\mathrm{Rt}$ & 89.0 & 2.5 \\
\hline & & & & Mangaotanean & $\mathrm{Rm}$ & 92.0 & 3 \\
\hline & & & & Arowhanan & $\mathrm{Ra}$ & 95.0 & 3 \\
\hline & & & \multirow{3}{*}{ Clarence Series } & Ngaterian & $\mathrm{Cn}$ & 100.0 & 5 \\
\hline & & & & Motuan & $\mathrm{Cm}$ & 103.0 & 3 \\
\hline & & & & Urutawan & $\mathrm{Cu}$ & 108.0 & 5 \\
\hline & & & & (Korangan) & Uk & $(117)$ & 9 \\
\hline & & & Taitai Series & $\begin{array}{c}\text { (no stages } \\
\text { designated) }\end{array}$ & $U$ & 144.2 & 27.2 \\
\hline & & & Oteke Series & Puaroan & Op & 148.5 & 4.3 \\
\hline & & & & Ohauan & Ko & 153.5 & 5 \\
\hline & Jurassic & & Kawhia Series & Heterian & $\mathrm{Kh}$ & 157.5 & 4 \\
\hline & & & & Temaikan & $\mathrm{Kt}$ & 178.0 & 20.5 \\
\hline & & & Heranai Series & Ururoan & $\mathrm{Hu}$ & 190.0 & 12 \\
\hline & & & & Aratauran & $\mathrm{Ha}$ & 200.0 & 10 \\
\hline
\end{tabular}


Appendix B: Wireline Abbreviations \& Oil Field Glossary 


\begin{tabular}{|c|c|c|}
\hline Acoustic Velocity & DT, DTC, MCF, DTSU & $\mathrm{ms} / \mathrm{ft}, \mathrm{ms} / \mathrm{m}$ \\
\hline Acoustic Velocity & DTL, LSS, BHC, DRH & $\mathrm{ms} / \mathrm{ft}, \mathrm{ms} / \mathrm{m}$ \\
\hline Bit Size & BIT, BS & inch \\
\hline Caliper - Acoustic image tools - Average & AVCA & inches, $\mathrm{mm}$ \\
\hline Caliper - Acoustic image tools - Maximum & CAL_MAX & inches, $\mathrm{mm}$ \\
\hline Caliper - Acoustic image tools - Minimum & CAL_MIN & inches, $\mathrm{mm}$ \\
\hline Caliper - Acoustic tools (Conventional) & CAL, CALS, CALI & inches, $\mathrm{mm}$ \\
\hline Caliper - Density tools & CAL, CALD & inches, $\mathrm{mm}$ \\
\hline Caliper - Resistivity image tools & $\mathrm{C} 13, \mathrm{C} 14$ & inches, $\mathrm{mm}$ \\
\hline Caliper - Resistivity image tools & $\mathrm{C} 24, \mathrm{C} 25$ & inches, $\mathrm{mm}$ \\
\hline Caliper - Resistivity image tools & $\mathrm{C} 36$ & inches, $\mathrm{mm}$ \\
\hline Caliper - Resistivity tools & CALI, CALR & inches, $\mathrm{mm}$ \\
\hline Caliper - Generic & CLI, CLD, CAL1,CAL2, & inches, $\mathrm{mm}$ \\
\hline Density & RHOB, DENS, ZDEN & $\mathrm{g} / \mathrm{cc}$ \\
\hline Density Correction & DRHO, HDRA, ZDNC & $\mathrm{g} / \mathrm{cc}$ \\
\hline Gamma ray - Sonic & GRS & GAPI \\
\hline Gamma ray - Density & GRD & GAPI \\
\hline Gamma ray - Imaging tool & GR & GAPI \\
\hline Gamma ray - Induction & GRI & GAPI \\
\hline Gamma ray - Laterlog & GRL & GAPI \\
\hline Gamma ray - Environmental correction & EGR & GAPI \\
\hline Imaging & FMI & Dimensionless \\
\hline Logging Parameters - Cable speed & CS, SPD & $\mathrm{m} / \mathrm{hr}, \mathrm{ft} / \mathrm{hr}$ \\
\hline Logging Parameters - Cable tension & TENS & $\mathrm{N}, \mathrm{lbs}, \mathrm{Kg}$ \\
\hline $\begin{array}{l}\text { Logging Parameters - Calibrated downhole } \\
\text { force }\end{array}$ & $\mathrm{CDF}$ & lbs \\
\hline Logging Parameters - Gain & EI & mamp \\
\hline Logging Parameters - Gain & EV & $\mathrm{V}$ \\
\hline Logging Parameters - Pad pressure & $\mathrm{PP}$ & Dimensionless \\
\hline Logging Parameters - Z-axis accelerometer & $\mathrm{AZ}$ & $\mathrm{m} / \mathrm{s}^{2}$ \\
\hline Neutron porosity & CNC, NEUT, NPHI, TNPH & $\%$, FRAC \\
\hline Orientation - Hole azimuth & DAZ, HAZI, HAZ & Degree \\
\hline Orientation - Hole deviation & DEV, DEVI & Degree \\
\hline Orientation - Magnetic field & ANOR & $\mathrm{m} / \mathrm{s}^{2}$ \\
\hline Orientation - Magnetic field & FINC & Degree \\
\hline Orientation - Magnetic field & FNOR & $\mathrm{A} / \mathrm{m}$ \\
\hline Orientation - Pad 1 azimuth & P1AZ, AZI & Degree \\
\hline Orientation - Relative bearing & $\mathrm{RB}, \mathrm{ROT}$ & Degree \\
\hline Photoelectric Factor & $\mathrm{Pe}, \mathrm{PEF}$ & barns/electron \\
\hline Resistivity - Deep & M1R6, AT60, LP34 & ohm.m \\
\hline Resistivity - Deep & $\mathrm{RD}$ & ohm.m \\
\hline Resistivity - Extra Deep & M1RX. LP40 & ohm.m \\
\hline Resistivity - Invaded zone & MLL, MSFL, RXO, RXO8 & ohm.m \\
\hline Resistivity - Medium & M1R3, LLM, ILM, AT30, LP28 & ohm.m \\
\hline Resistivity - Medium/Shallow & RS, LP22 & ohm.m \\
\hline Resistivity - Shallow & M1R2, AT20, LLS, LP16, 16N & ohm.m \\
\hline Resistivity - Spherically focussed & SFL, SFLU & ohm.m \\
\hline Resistivity - Very Deep & M1R9, LLD, ILD, AT90 & ohm.m \\
\hline Resistivity - Very Shallow & M1R1, LLS, AT10 & ohm.m \\
\hline Self Potential & $\mathrm{SP}$ & $\mathrm{mV}$ \\
\hline Spectral GR - Potassium & $\mathrm{K}$, POTA & $\%$ \\
\hline Spectral GR - Thorium & Th, THOR & $\mathrm{ppm}$ \\
\hline Spectral GR - Uranium & U, URAN & $\mathrm{ppm}$ \\
\hline
\end{tabular}




\section{Annulus}

The space between the drill string and the well wall, or between casing strings, or between the casing and the production tubing.

\section{Arnold Series}

New Zealand Series spanning 43.0-34.4Ma.

\section{Associated Gas}

Natural gas associated with oil accumulations, which may be dissolved in the oil at reservoir conditions or may form a cap of free gas above the oil.

\section{Barrel}

A unit of volume measurement used for petroleum and its products $(7.3$ barrels $=1$ ton 6.29 barrels $=1$ cubic meter $)$.

bbl

One barrel of oil; 1 barrel $=35$ Imperial gallons (approx.), or 159 litres (approx.); 7.5 barrels $=1$ ton (approx.); 6.29 barrels $=1$ cubic meter.

bcf

Billion cubic feet; 1 bcf $=0.83$ million tons of oil equivalent.

bcm

Billion cubic meters $(1$ cubic meter $=35.31$ cubic feet $)$.

\section{Borehole}

The hole as drilled by the drill bit.

Bortonian (Ab) Stage

New Zealand Stage spanning 43.0-37.0Ma

\section{Cap rock}

Impermeable rock overlying an oil or gas reservoir that tends to prevent migration of the reservoir fluids from the reservoir.

\section{Capped well}

A well capable of production but lacking wellhead installations and a pipeline connection.

\section{Casing}

Steel pipe threaded together and cemented into a well as drilling progresses to prevent the wall of the hole from caving in during drilling and to provide a means of extracting oil/gas if the well is productive.

\section{Casing string}

The steel tubing that lines a well after it has been drilled. It is formed from sections of steel tube screwed together.

\section{Circulate}

Cycling of the drilling fluid through the drill string and wellbore while drilling is temporarily suspended. This is done to condition the drilling fluid and wellbore before drilling proceeds.

\section{Clarence Series}

New Zealand Series spanning 108.4-95.2Ma.

\section{Claystone}

A term used to describe a clastic sedimentary rock that is composed primarily of clay-sized particles (less than 1/256 $\mathrm{mm}$ in diameter).

\section{Condensate}

Hydrocarbons which are in the gaseous state under reservoir conditions and which become liquid when temperature or pressure is reduced. A mixture of pentanes and higher hydrocarbons.

\section{Coring}

Taking rock samples from a well by means of a special tool called a "core barrel".

\section{Cretaceous Period}

Global Geochronological scale spanning 145.0-65.0Ma

\section{Cuttings}

Rock chips cut from the formation by the drill bit, and brought to the surface with the mud. Used by geologists to obtain formation data.

\section{Danian Age}

Global Geochronological scale spanning $65.0-61.0 \mathrm{Ma}$

\section{Dannevirke Series}

New Zealand Series timescale spanning 65.0-43.0Ma.

\section{Drill bit}

The component at the end of the drill string that cuts the rock and makes hole.

\section{Drill pipe}

Steel pipe, in approximately 30-foot (9-meter) lengths, screwed together to form a continuous pipe extending from the drilling rig to the drilling bit at the bottom of the hole. Rotation of the drill pipe and bit causes the bit to bore through the rock.

\section{Drilling rig}

A drilling unit that is not permanently fixed to the seabed, e.g. a drillship, a semi-submersible or a jack-up unit. Also means the derrick and its associated machinery.

\section{Drill string}

String of individual joints of pipe that extends from the bit to the kelly and carries the mud down to, and rotates, the bit.

\section{Drilling Fluids}

While a mixture of clay and water is the most common drilling fluid, wells can also be drilled with air, natural gas, oil, or plain water as the drilling fluid.

\section{Dry hole}

Generally refers to any well that does not produce oil or gas in commercial quantities.

\section{Dry Gas}

Natural gas composed mainly of methane with only minor amounts of ethane, propane and butane and little or no heavier hydrocarbons in the gasoline range.

\section{Eocene Epoch}

Global Geochronological scale spanning 55.5-33.7Ma.

\section{Exploration drilling}

Drilling carried out to determine whether hydrocarbons are present in a particular area or structure. 


\section{Exploration phase}

The phase of operations which covers the search for oil or gas by carrying out detailed geological and geophysical surveys followed up where appropriate by exploratory drilling.

\section{Exploration well}

A well drilled in an unproven area. Also known as a "wildcat well".

\section{Field}

An area consisting of a single reservoir or multiple reservoirs all grouped on, or related to, the same individual geological structural feature or stratigraphic condition. The field name refers to the surface area, although it may refer to both the surface and the underground productive formations.

\section{Fullbore MicroIamging (FMI)}

Wireline tool with a 4 arm, pad-based resistivity measurement device with 2 pads on each arm in contact with the borehole wall.

\section{Fracturing (frac)}

A method of stimulation production by opening new flow channels in the rock surrounding a production well by pumping proppants and fluid into the well at high pressure and volume.

\section{Gas cap}

Free gas, separate from, but overlying an oil zone that occurs within the same producing formation as oil. Since gas is lighter, it occupies the upper part of the reservoir.

\section{Haumurian (Mh) Stage}

New Zealand Stage spanning 84.0-65.0Ma.

\section{Heretaugan (Dh) Stage}

New Zealand Stage spanning 49.5-46.2Ma.

\section{Hydrocarbons}

Organic chemical compounds of hydrogen and carbon whose densities, boiling points, and freezing points increase as their molecular weights increase. The molecular structure of the most common petroleum hydrocarbon compounds varies from the simplest - methane, a constituent of natural gas - to the very heavy and complex.

\section{Illite Clay}

A group of white or pale-coloured potassium-aluminiummagnesium-iron silicate clay minerals.

\section{Jurassic Period}

Global Geochronological scale spanning 199.6-145.5Ma..

\section{Kaolinite Clay}

A white aluminium silicate mineral of the kaolin group.

\section{Kelly}

Square or hexagonal steel pipe about 43 feet (13 meters) long which transmits torque from the rotary table to drill string, thus rotating the string and bit.

\section{Liquids}

Hydrocarbons in solution in natural gas which are liquefiable at surface temperature and pressure or by treatment and processing.

\section{Log}

Systematic recording of data. To conduct a survey inside a borehole to gather information about the subsurface formations; the results of such a survey. Logs typically consist of several curves on a long grid that describe properties within the wellbore or surrounding formations that can be interpreted to provide information about the location of oil, gas, and water. Also called well logs, borehole logs, wireline logs.

\section{Lutetian Age}

Global Geochronological scale spanning 49.0-41.3Ma.

\section{Maastrichtian Age}

Global Geochronological scale spanning 70.6-65.0Ma.

\section{Mangaorapan (Dm) Stage}

New Zealand Stage spanning 53.0-49.5Ma.

\section{Mata Series}

New Zealand Series spanning 86.5-65.0Ma.

\section{Mbrt}

Metres below rotary table, a datum used by drillers.

MD

Measured depth, a datum used by drillers.

\section{Migration}

Natural movement of oil or gas within or out of a formation.

\section{Mud (drilling)}

Usually colloidal suspensions of clays in water with chemical additives that are circulated through the wellbore during rotary drilling and workover operations. Can use oil as the main medium.

\section{Mudstone}

A fine grained sedimentary rock whose original constituents were clays or muds. Grain size is up to $0.0625 \mathrm{~mm}$ with individual grains too small to be distinguished without a microscope.

\section{Neogene Period}

Global Geochronological scale spanning 23.8-present Ma.

\section{Oilfield}

Loosely defined term referring to an area where oil is found. May also include the oil reservoir, the surface and wells, and production equipment.

\section{Oligocene Epoch}

Global Geochronological scale spanning $65.0-55.5 \mathrm{Ma}$

\section{Open hole}

Uncased part of a well.

\section{Paleocene Epoch}

Global Geochronological scale spanning 33.7-23.9Ma.

\section{Pay or pay section}

Producing formation, or that formation which represents the objective of drilling.

Penetration, rate of ( ROP) 
Rate at which the drill bit proceeds in the deepening of the wellbore and usually expressed as feet (meters) per hour.

\section{Permeability}

Capacity of a porous rock formation to allow fluid to flow within the interconnecting pore network.

\section{Permian Period}

Global Geochronological scale spanning 299.0-250.4Ma.

\section{Piripauan (Mp) Stage}

New Zealand Stage spanning 86.5-84.0Ma.

\section{Plug \& abandon}

Act of placing cement plugs in a hole to prevent unwanted vertical migration in an abandoned well.

\section{Porangan (Dp) Stage}

New Zealand Stage spanning 46.2-43.0Ma.

Porosity

Volume of pore spaces between mineral grains expressed as a percentage of the total rock volume. Thus porosity measures the capacity of the rock to hold oil, gas, or water.

Potential

Actual or maximum volume of oil and/or gas that a well is capable of producing.

\section{Reservoir}

Porous, permeable sedimentary rock structure or trap containing oil and/or gas. A reservoir can contain more than one pool.

\section{Raukumara Series}

New Zealand Series spanning 95.2-86.5Ma.

\section{Rotary drilling}

Method of drilling in which the drill pipe is rotated to rotate a bit.

Rotary table

Equipment over the wellbore which transfers power from the engines to produce a rotary motion. Via bushings and gears the rotary motion is transferred to the kelly and through to the drill string.

\section{Sandfrac}

Method of fracturing subsurface rock formations by injection of fluid and sand under high pressure to increase permeability. Fractures induced in the rock by the hydraulic pressure are kept open by the grains of sand.

\section{Sandstone}

Sandstone (sometimes known as arenite) is a sedimentary rock composed mainly of sand-sized $(0.0625 \mathrm{~mm}$ to $2 \mathrm{~mm})$ minerals or rock grains. Most sandstone is composed of quartz and/or feldspar.

\section{Selandian Age}

Global Geochronological scale spanning 61.0-57.9Ma.

\section{Semi-submersible rig}

A mobile offshore drilling unit that floats on the water's surface above the subsea wellhead and is anchored in place. The semi-submersible rig gets its name from pontoons at its base which are empty while being towed to the drilling location and are partially filled with water to steady the rig over the well.

\section{Siltstone}

Finer than sandstone and coarser than claystones, siltstone is defined as grains between 3.9 and $62.5 \mu \mathrm{m}$.

Shale

A fine-grained, clastic sedimentary rock composed of mud that is a mix of flakes of clay minerals and tiny fragments (silt-sized particles) of other minerals, especially quartz and calcite.

\section{Shale Gas}

Shale gas is natural gas produced from shale.

\section{Smectite Clay}

A group of variably-coloured sodium-calcite-magnesiumiron-aluminium-silicate clay minerals.

\section{Spud or spudding in}

Commencement of actual drilling of well.

SS

Subsea floor measurement, a datum used by drillers.

\section{Stabiliser}

A centralizer installed in the drill string to centre the string in the hole and to stiffen the string to resist bending and deviation.

\section{Stratigraphic trap}

Subsurface formation created by sedimentation that might trap an accumulation of oil and/or gas

\section{Structure}

Subsurface geological feature capable of acting as a reservoir for oil and/or gas.

\section{Syncline}

Trough-shaped subsurface structure of folded stratified rock. Opposite of anticline.

\section{Thanetian Age}

Global Geochronological scale spanning 57.9-55.5Ma.

\section{Teurian (Dt) Stage}

New Zealand Stage spanning 65.0-55.5Ma.

\section{Tight Gas}

Tight gas is natural gas which is difficult to access because of the nature of the rock and sand surrounding the deposit.

\section{TD}

Total depth, maximum depth reached in a well.

\section{Trap}

Any geological structure which precludes the migration of oil and gas through subsurface rocks, causing the hydrocarbons to accumulate into pools.

\section{Triassic Period}

Global Geochronological scale spanning 250.4-199.6Ma.

\section{TWT}

Two way travel time.

TVD

True vertical depth, a datum used by drillers. 


\section{Waipawan (Dw) Stage}

New Zealand Stage spanning 55.5-53.9Ma.

\section{Weight on bit (WOB)}

The amount of downward force placed on a bit by the weight of the drill stem.

\section{Wellbore}

The hole made by a drilling bit.

\section{Wellhead}

The equipment at the surface of a well used to control the pressure; the point at which the hydrocarbons and water exit the ground.

\section{Well logging}

Recording information about subsurface geologic formations; methods include records kept by the driller, mud and cutting analysis, core analysis, drill stem tests, electric and radioactivity procedures.

\section{Wet Gas}

Term for a gaseous mixture of hydrocarbons that contain a significant amount of compounds with molecular weights heavier than ethane.

\section{Wireline}

A slender rod-like or threadlike small-diameter piece of metal used to lower tools, such as logging tools, perforating guns, valves, and fishing tools into a well. May include electrical conductors to power and control instruments and to convey data to the surface.

\section{Ypresian Age}

Global Geochronological scale spanning 55.5-49.0Ma.

\section{Zealandia}

The mainly submerged continental mass that split from Gondwana at c.a. 85 Ma. 
Appendix C: Formation Tops 


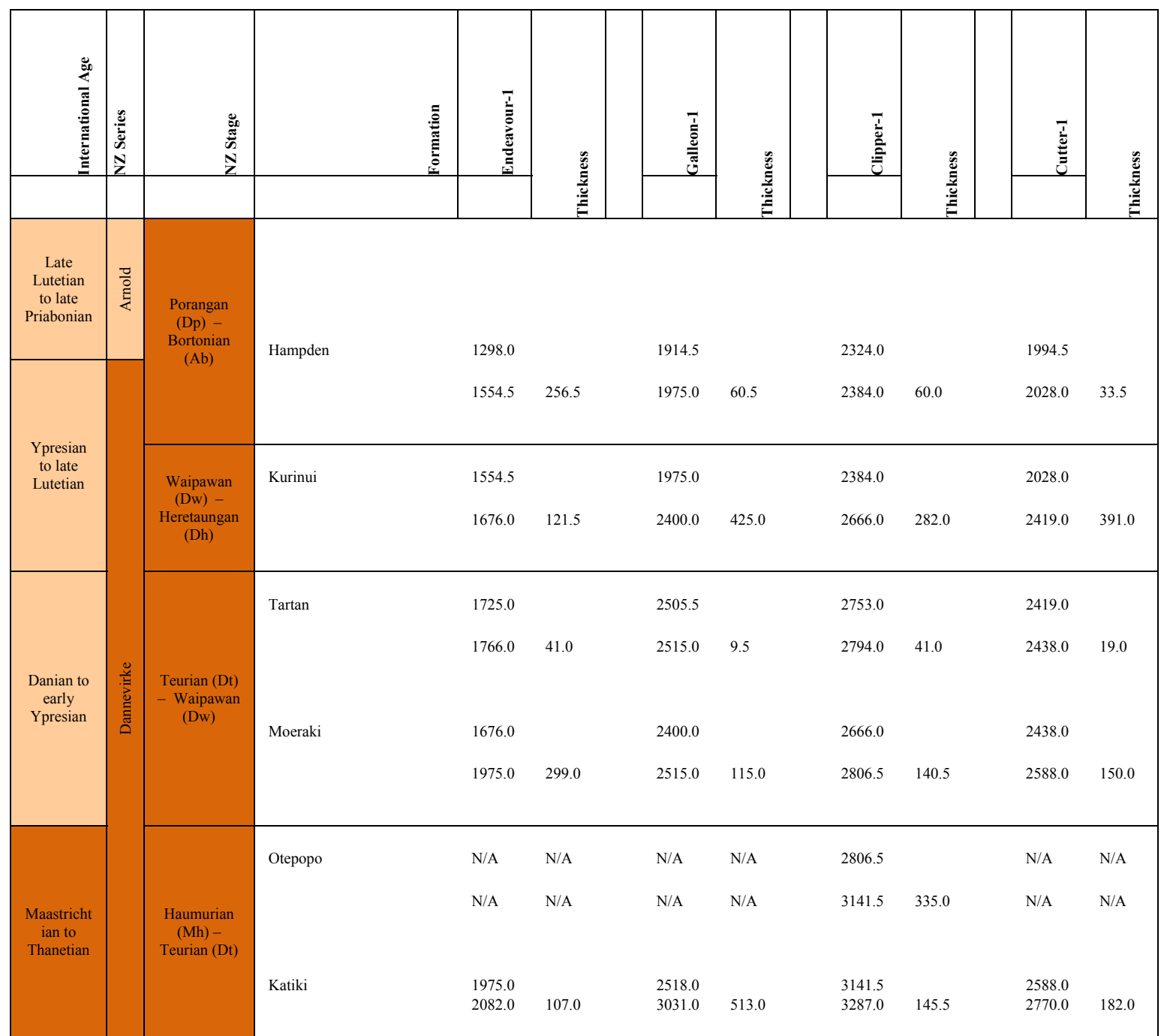

Data sourced from Shell BP Todd (1984a); Shell BP Todd Canterbury Services Ltd (1984b); Shell BP Todd Canterbury Services Ltd (1984c); Shell BP Todd Canterbury Services Ltd (1984d); Hawkes \& Mound (1984); Wilson I. R. (1985); and Tap Oil Limited (2007 ). Pocknall et al. (1991). 
Appendix D: Thin Section Analysis 


\begin{tabular}{|c|c|c|c|c|c|c|c|c|c|}
\hline \multirow[t]{2}{*}{$\begin{array}{l}\text { ocatio } \\
\text { n }\end{array}$} & \multirow[t]{2}{*}{ Formation } & \multirow{2}{*}{$\begin{array}{l}\text { Sample } \\
\text { Location }\end{array}$} & \multirow[t]{2}{*}{ Sample ID } & $\begin{array}{l}\text { Sample } \\
\text { Depth }\end{array}$ & $\begin{array}{c}\begin{array}{c}\text { Feldspa } \\
\mathbf{r}\end{array} \\
\end{array}$ & $\begin{array}{c}\text { Lithic } \\
\mathrm{s}\end{array}$ & $\begin{array}{c}\text { Quart } \\
\mathrm{z}\end{array}$ & \multirow[t]{2}{*}{ Data Source } & \multirow{2}{*}{$\begin{array}{c}\text { Classification } \\
\text { (after Folk et al. 1970) }\end{array}$} \\
\hline & & & & (m) & & $\%$ & & & \\
\hline \multirow{32}{*}{ 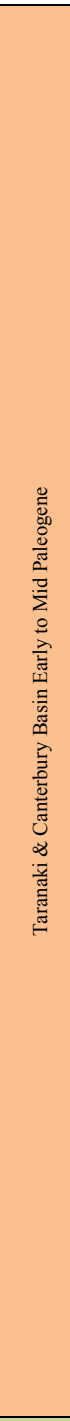 } & Hampden Formation & End-1 & $\begin{array}{l}\text { Set } 1 \& 4 \\
\text { Box3 }\end{array}$ & 1500 & 3.0 & 18.0 & 79.0 & This study & Sublitharenite \\
\hline & Kurinui Formation & End-1 & $\begin{array}{l}\text { Set } 2 \& 5 \text { Box } \\
4\end{array}$ & 1600 & 4.0 & 15.0 & 81.0 & & Sublitharenite \\
\hline & Kurinui Formation & Gall-1 & Set 1 Box 14 & 2300 & 5.0 & 15.0 & 80.0 & & Sublitharenite \\
\hline & Kurinui Formation & Cutt-1 & $\begin{array}{l}10 \\
\text { Set F/E Box }\end{array}$ & 2110 & 5.0 & 13.0 & 82.0 & & Sublitharenite \\
\hline & Kurinui Formation & Cutt-1 & $\begin{array}{l}11 \\
\text { Set F/E Box }\end{array}$ & 2140 & 4.0 & 8.0 & 88.0 & & Sublitharenite \\
\hline & Kurinui Formation & Cutt-1 & $\begin{array}{l}11 \\
\text { Set } 2 \& 5 \text { Box }\end{array}$ & 2390 & 2.0 & 8.0 & 90.0 & & Sublitharenite \\
\hline & Tartan Formation & End-1 & $\begin{array}{l}4 \\
\text { Set } 2 \& 5 \text { Box }\end{array}$ & 1750 & 2.0 & 12.0 & 86.0 & & Sublitharenite \\
\hline & Tartan Formation & End-1 & 4 & 1760 & 3.0 & 12.0 & 85.0 & & Sublitharenite \\
\hline & Tartan Formation & Gall-1 & Set1 Box 15 & 2500 & 4.0 & 15.0 & 81.0 & & Sublitharenite \\
\hline & Moeraki Formation & Gall-1 & Set 1 Box 14 & 2450 & 10.0 & 15.0 & 75.0 & & Subfeldsarenite \\
\hline & Moeraki Formation & Cutt-1 & $\begin{array}{l}11 \\
\text { SetF/E Box }\end{array}$ & 2430 & 12.0 & 8.0 & 80.0 & & Litharenite \\
\hline & Moeraki Formation & Cutt-1 & $\begin{array}{l}11 \\
\text { SetF/E Box }\end{array}$ & 2460 & 9.0 & 17.0 & 74.0 & & Litharenite \\
\hline & Moeraki Formation & Cutt-1 & & 2505 & 12.0 & 16.0 & 72.0 & & Sublitharenite \\
\hline & Katiki Formation & Gall-1 & Set 1 Box 18 & 2550 & 2.0 & 10.0 & 88.0 & & Sublitharenite \\
\hline & Katiki Formation & Gall-1 & $\begin{array}{l}\text { Set } 1 \text { Box } 19 \\
\text { Set F/F Box }\end{array}$ & 2650 & 3.0 & 11.0 & 86.0 & & Sublitharenite \\
\hline & Katiki Formation & Cutt-1 & $\begin{array}{l}11 \\
\text { Set F/E Box }\end{array}$ & 2640 & 6.0 & 10.0 & 84.0 & & Sublitharenite \\
\hline & Katiki Formation & Cutt-1 & 11 & 2660 & 4.0 & 11.0 & 85.0 & & Sublitharenite \\
\hline & Otepopo Formation & Clip-1 & Set 1 Box 21 & 3000 & 5.0 & 15.0 & 80.0 & & Sublitharenite \\
\hline & Otepopo Formation & Clip-1 & Set 1 Box 22 & 3100 & 4.0 & 17.0 & 79.0 & & Sublitharenite \\
\hline & Otepopo Formation & Clip-1 & Set 1 Box 23 & 3150 & 4.0 & 15.0 & 81.0 & & Sublitharenite \\
\hline & Mangahewa Formation & Kapuni-1 & $\mathrm{N} / \mathrm{A}$ & 3261 & 16.3 & 16.3 & 27 & Smale et al. (1999) & Feldsarenite \\
\hline & Mangahewa Formation & Kapuni-1 & N/A & 3332.6 & 7.3 & 11.7 & 26.1 & & Feldsarenite \\
\hline & Mangahewa Formation & New Plymouth-2 & $\mathrm{N} / \mathrm{A}$ & 3912.7 & 14.3 & 4.9 & 39 & & Feldsarenite \\
\hline & Mangahewa Formation & New Plymouth-2 & N/A & 3913.6 & 12.7 & 3.9 & 33 & & Feldsarenite \\
\hline & Mangahewa Formation & New Plymouth-2 & N/A & 3915 & 14 & 5.9 & 33 & & Feldsarenite \\
\hline & Mangahewa Formation & New Plymouth-2 & $\mathrm{N} / \mathrm{A}$ & 4039.1 & 24.3 & 3.3 & 35.7 & & Lithic Feldsarenite \\
\hline & Kaimiro Formation & Kapuni-3 & $\mathrm{N} / \mathrm{A}$ & 3685 & 5.9 & 4.3 & 38.7 & & Lithic Feldsarenite \\
\hline & Kaimiro Formation & Kapuni-3 & N/A & 3710.9 & 7.6 & 0.6 & 53.1 & & Lithic Feldsarenite \\
\hline & Kaimiro Formation & Kapuni-8 & N/A & 4058.2 & 14.7 & 7.3 & 36.7 & & Lithic Feldsarenite \\
\hline & Kaimiro Formation & Kapuni-14 & $\mathrm{N} / \mathrm{A}$ & 4075.1 & 10.3 & 2.3 & 49.4 & & Lithic Feldsarenite \\
\hline & Farewell Formation & Kapuni-13 & $\mathrm{N} / \mathrm{A}$ & 5185.14 & 32.6 & 7.2 & 24.7 & & Lithic Feldsarenite \\
\hline & Farewell Formation & Kapuni-13 & $\mathrm{N} / \mathrm{A}$ & 5519.4 & 23.1 & 3.9 & 23.7 & & Lithic Feldsarenite \\
\hline \multirow{21}{*}{ 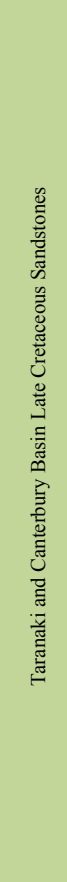 } & Herbert Formation & Clip-1 & N/A & 2781.5 & 0.30 & 9.60 & 53.00 & Higgs (2007a) & Sublitharenite \\
\hline & Herbert Formation & Clip-1 & N/A & 2787 & 0.30 & 5.60 & 69.60 & & Sublitharenite \\
\hline & Herbert Formation & Clip-1 & N/A & 2829.5 & 0.30 & 4.30 & 72.00 & & Sublitharenite \\
\hline & Herbert Formation & $\begin{array}{l}\text { Clip-1 } \\
\text { Mangarakau }\end{array}$ & N/A & 2881 & 0.30 & 3.60 & 36.00 & & Sublitharenite \\
\hline & North Cape Formation & Swamp & P75972 & $\mathrm{N} / \mathrm{A}$ & 29.30 & 9.30 & 27.30 & Higgs et al. (2010) & Lithic Feldsarenite \\
\hline & North Cape Formation & $\begin{array}{l}\text { Swamp } \\
\text { Mangarakau }\end{array}$ & P75973 & $\mathrm{N} / \mathrm{A}$ & 15.00 & 4.60 & 23.60 & & Feldsarenite \\
\hline & North Cape Formation & Swamp & P75974 & N/A & 23.30 & 4.90 & 30.00 & & $\begin{array}{l}\text { Feldsarenite } \\
\text { Feldspathic }\end{array}$ \\
\hline & North Cape Formation & Maori Point & P75979 & N/A & 17.00 & 3.60 & 25.40 & & Litharenite \\
\hline & North Cape Formation & Maori Point & P75983 & N/A & 31.00 & 16.70 & 21.70 & & Lithic Feldsarenite \\
\hline & North Cape Formation & Maori Point & P75984 & N/A & 29.00 & 16.70 & 29.00 & & Lithic Feldsarenite \\
\hline & North Cape Formation & McDonalds Farm & P75970 & N/A & 24.00 & 25.60 & 24.70 & & Feldsarenite \\
\hline & North Cape Formation & Muddy Creek & P75975 & N/A & 30.60 & 6.70 & 21.70 & & Feldsarenite \\
\hline & North Cape Formation & Muddy Creek & P75976 & N/A & 23.30 & 7.90 & 34.70 & & Feldsarenite \\
\hline & North Cape Formation & Muddy Creek & P75977 & $\mathrm{N} / \mathrm{A}$ & 23.00 & 9.30 & 27.60 & & Feldsarenite \\
\hline & North Cape Formation & Muddy Creek & P75978 & $\mathrm{N} / \mathrm{A}$ & 29.3 & 9.3 & 27.3 & & Feldsarenite \\
\hline & North Cape Formation & Oyster Point & P75985 & N/A & 26.4 & 9.3 & 20.7 & & Feldsarenite \\
\hline & North Cape Formation & Oyster Point & P75986 & N/A & 26.0 & 6.6 & 25.7 & & Feldsarenite \\
\hline & North Cape Formation & Oyster Point & P75987 & N/A & 27.0 & 7.1 & 16.4 & & Feldsarenite \\
\hline & North Cape Formation & Oyster Point & P75988 & N/A & 24.4 & 4.6 & 28.0 & & Lithic Feldsarenite \\
\hline & North Cape Formation & Paturau River & P75971 & N/A & 23.3 & 13.7 & 25.0 & & Lithic Feldsarenite \\
\hline & North Cape Formation & Kupe South-4 & P756552 & 3527 & 29.3 & 11.0 & 17.3 & & Feldsarenite \\
\hline
\end{tabular}




\begin{tabular}{|c|c|c|c|c|c|c|c|c|c|}
\hline & North Cape Formation & Kupe South-4 & P756553 & 3619 & 32.3 & 8.0 & 18.0 & & Feldsarenite \\
\hline & North Cape Formation & Kupe South-4 & P756554 & 3626 & 40.0 & 6.0 & 22.4 & & Lithic Feldsarenite \\
\hline & North Cape Formation & Kupe South-4 & P756555 & 3714 & 38.4 & 11.8 & 23.0 & & Feldsarenite \\
\hline & North Cape Formation & Kupe South-4 & P756556 & 3723 & 30.0 & 12.4 & 23.3 & & Lithic Feldsarenite \\
\hline & North Cape Formation & Kupe South-4 & P756557 & 3758 & 26.0 & 8.6 & 21.0 & & Lithic Feldsarenite \\
\hline & North Cape Formation & Pukeko-1 & ND & 4060.8 & 24.0 & 3.0 & 30.0 & $\begin{array}{l}\text { Pollock \& Funnell } \\
\text { (2004) }\end{array}$ & Feldsarenite \\
\hline & North Cape Formation & Pukeko-1 & ND & 4063 & 27.7 & 1.7 & 34.3 & & Feldsarenite \\
\hline & North Cape Formation & Pukeko-1 & ND & 4067 & 34.7 & 1.7 & 28.3 & & Feldsarenite \\
\hline & North Cape Formation & Pukeko-1 & ND & 4083 & 19.4 & 3.7 & 35.7 & & Feldsarenite \\
\hline & North Cape Formation & Pukeko-1 & ND & 4097.3 & 25.7 & 1.0 & 37.3 & & Feldsarenite \\
\hline & North Cape Formation & Pukeko-1 & ND & 4099 & 20.0 & 3.0 & 38.0 & & Feldsarenite \\
\hline & North Cape Formation & Pukeko-1 & ND & 4230 & 19.3 & 2.0 & 41.0 & & Feldsarenite \\
\hline & North Cape Formation & Pukeko-1 & ND & 4137.5 & 18.7 & 3.3 & 39.0 & & Feldsarenite \\
\hline & North Cape Formation & Pukeko-1 & ND & 4142.4 & 16.7 & 4.7 & 43.0 & & Feldsarenite \\
\hline & North Cape Formation & Pukeko-1 & ND & 4152.8 & 17.6 & 4.0 & 49.3 & & Feldsarenite \\
\hline & North Cape Formation & Tahi-1 & P76511 & 1270 & 22.0 & 3.0 & 39.3 & Higgs et al. (2010) & Litharenite \\
\hline & North Cape Formation & Tahi-1 & P76513 & 1320.5 & 34.7 & 16.7 & 22.4 & & Lithic Feldsarenite \\
\hline & North Cape Formation & Tahi-1 & P76512 & 1381.9 & 30.3 & 5.9 & 22.0 & & Feldsarenite \\
\hline & North Cape Formation & Tane-1 & P76522 & 3515 & 32.0 & 9.0 & 30.3 & & Feldsarenite \\
\hline & North Cape Formation & Tane-1 & P76517 & 3600 & 37.3 & 6.3 & 19.0 & & Feldsarenite \\
\hline & North Cape Formation & Tane-1 & P76520 & 3691.45 & 34.6 & 11.2 & 27.0 & & Lithic Feldsarenite \\
\hline & North Cape Formation & Tane-1 & P76521 & 3694.25 & 34.4 & 11.9 & 27.7 & & Lithic Feldsarenite \\
\hline & North Cape Formation & Taranga-1 & P76527 & 4138.5 & 17.3 & 8.3 & 20.0 & & Feldsarenite \\
\hline & North Cape Formation & Wainui-1 & P76523 & 3776.5 & 15.0 & 6.6 & 34.0 & & Feldsarenite \\
\hline & North Cape Formation & Wainui-1 & P76524 & 3785 & 21.4 & 10.9 & 37.4 & & Lithic Feldsarenite \\
\hline & North Cape Formation & Wainui-1 & P76525 & 3804 & 18.0 & 11.5 & 29.1 & & Lithic Feldsarenite \\
\hline & North Cape Formation & Wainui-1 & P76526 & 3867 & 16.0 & 11.6 & 25.0 & & Lithic Feldsarenite \\
\hline & Rakopi Formation & Collingwood & P69079 & $\mathrm{N} / \mathrm{A}$ & 10.3 & 4.7 & 36.3 & Browne et al. (2008) & Lithic Feldsarenite \\
\hline & Rakopi Formation & Collingwood & P69080 & N/A & 12.9 & 8.3 & 35.7 & & Lithic Feldsarenite \\
\hline & Rakopi Formation & Collingwood & P69081 & $\mathrm{N} / \mathrm{A}$ & 14.2 & 6.7 & 35.0 & & Litharenite \\
\hline & Rakopi Formation & Paturau River & P69083 & $\mathrm{N} / \mathrm{A}$ & 16.3 & 7.6 & 26.7 & & Litharenite \\
\hline & Rakopi Formation & Paturau River & P69084 & $\mathrm{N} / \mathrm{A}$ & 39.0 & 9.7 & 29.9 & & Lithic Feldsarenite \\
\hline & Rakopi Formation & Paturau River & P69086 & $\mathrm{N} / \mathrm{A}$ & 31.0 & 6.7 & 34.1 & & Feldsarenite \\
\hline & Rakopi Formation & Tahi-1 & P76515 & 1478.9 & 25.0 & 11.3 & 42.3 & & Litharenite \\
\hline & Rakopi Formation & Tahi-1 & P76514 & 1736 & 46.3 & 9.0 & 18.0 & & $\begin{array}{l}\text { Feldspathic } \\
\text { Litharenite }\end{array}$ \\
\hline & Rakopi Formation & Tane-1 & P76518 & 4052 & 42.7 & 7.0 & 23.1 & & Feldsarenite \\
\hline & Rakopi Formation & Tane-1 & P76519 & 4177 & 39.4 & 10.4 & 25.7 & & Feldsarenite \\
\hline & Western Marginal Facies of & & & & & & & & Feldsarenite \\
\hline & $\begin{array}{l}\text { NZ } \\
\text { Western Maroinal Facies of }\end{array}$ & N/A & SK-4 & N/A & 26.0 & 67.0 & 3.0 & Dickinson (1971) & Lithsarenite \\
\hline & NZ & $\mathrm{N} / \mathrm{A}$ & SP-8 & $\mathrm{N} / \mathrm{A}$ & 29.0 & 63.0 & 1.0 & & Lithsarenite \\
\hline & Western Marginal Facies of & & & & & & & & Feldsarenite \\
\hline & $\begin{array}{l}\text { NZ } \\
\text { Western Marginal Facies of }\end{array}$ & N/A & SD-7 & N/A & 46.0 & 48.0 & 3.0 & & $\begin{array}{l}\text { Lithsarenite } \\
\text { Feldsarenite }\end{array}$ \\
\hline & NZ & $\mathrm{N} / \mathrm{A}$ & SP-5 & $\mathrm{N} / \mathrm{A}$ & 47.0 & 48.0 & 2.0 & & Lithsarenite \\
\hline & $\begin{array}{l}\text { Western Marginal Facies of } \\
\text { NZ }\end{array}$ & $\mathrm{N} / \mathrm{A}$ & NC-8 & $\mathrm{N} / \mathrm{A}$ & 33.0 & 37.0 & 14.0 & & Lithic Feldsarenite \\
\hline 总 & $\begin{array}{l}\text { Western Marginal Facies of } \\
\text { NZ }\end{array}$ & N/A & SD-12 & $\mathrm{N} / \mathrm{A}$ & 45.0 & 35.0 & 14.0 & & Lithic Feldsarenite \\
\hline 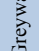 & $\begin{array}{l}\text { Western Marginal Facies of } \\
\text { NZ }\end{array}$ & $\mathrm{N} / \mathrm{A}$ & SD-13 & N/A & 46.0 & 29.0 & 170 & & $\begin{array}{l}\text { Feldsarenite } \\
\text { Sitharenite }\end{array}$ \\
\hline క్ & Western Marginal Facies of & N/A & SD-15 & $\mathrm{N} / \mathrm{A}$ & 46.0 & & 17.0 & & $\begin{array}{l}\text { Lithsarenite } \\
\text { Feldsarenite }\end{array}$ \\
\hline 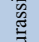 & $\mathrm{NZ}$ & N/A & SD-22 & N/A & 31.0 & 43.0 & 18.0 & & Lithsarenite \\
\hline 5 & $\begin{array}{l}\text { Western Marginal Facies of } \\
\text { NZ }\end{array}$ & $\mathrm{N} / \mathrm{A}$ & SK-2 & $\mathrm{N} / \mathrm{A}$ & 40.0 & 36.0 & 16.0 & & \\
\hline 馬 & Eastern Marginal Facies of & & & & & & & & Feldspathic \\
\hline है & $\begin{array}{l}\text { NZ } \\
\text { Fastern Maroinal Facies of }\end{array}$ & N/A & SK-7 & N/A & 32.0 & 59.0 & 5.0 & MacKinnon (1983) & Lithsarenite \\
\hline$\stackrel{n}{g}$ & NZ & N/A & NB-1C & $\mathrm{N} / \mathrm{A}$ & 46.0 & 39.0 & 7.0 & & Lithic Feldsarenite \\
\hline 胥 & $\begin{array}{l}\text { Eastern Marginal Facies of } \\
\text { NZ }\end{array}$ & N/A & NA-1 & N/A & 39.0 & 40.0 & 12.0 & & $\begin{array}{l}\text { Feldspathic } \\
\text { Litsparenite }\end{array}$ \\
\hline 3 & Eastern Marginal Facies of & & $N A-1$ & N/A & 39.0 & & & & Feldspathic \\
\hline $\mathrm{z}$ & $\begin{array}{l}\text { NZ } \\
\text { Eastern Marginal Facies of }\end{array}$ & N/A & SO-5 & N/A & 30.0 & 34.0 & 25.0 & & Lithsarenite \\
\hline & $\begin{array}{l}\text { Eastern Marginal Facies of } \\
\text { NZ }\end{array}$ & $\mathrm{N} / \mathrm{A}$ & SO-4 & $\mathrm{N} / \mathrm{A}$ & 37.0 & 27.0 & 30.0 & & Lithic Feldsarenite \\
\hline & $\begin{array}{l}\text { Eastern Marginal Facies of } \\
\text { NZ }\end{array}$ & $\mathrm{N} / \mathrm{A}$ & SO-6 & $\mathrm{N} / \mathrm{A}$ & 37.0 & 24.0 & 33.0 & & Lithic Feldsarenite \\
\hline & $\begin{array}{l}\text { Eastern Marginal Facies of } \\
\text { NZ }\end{array}$ & $\mathrm{N} / \mathrm{A}$ & SL-5 & $\mathrm{N} / \mathrm{A}$ & 31.0 & 28.0 & 35.0 & & Lithic Feldsarenite \\
\hline & $\begin{array}{l}\text { Eastern Marginal Facies of } \\
\mathrm{NZ}\end{array}$ & $\mathrm{N} / \mathrm{A}$ & SL-4 & $\mathrm{N} / \mathrm{A}$ & 38.0 & 17.0 & 41.0 & & Lithic Feldsarenite \\
\hline & Eastern Marginal Facies of & N/A & SO-1 & $\mathrm{N} / \mathrm{A}$ & 27.0 & 20.0 & 41.0 & & Lithic Feldsarenite \\
\hline
\end{tabular}




\begin{tabular}{|l|l|l|l|lll|l|} 
NZ & & & & & & & \\
Eastern Marginal Facies of & & & & & & & \\
NZ & SO-2 & N/A & 25.0 & 19.0 & 47.0 & & Lithic Feldsarenite \\
\hline
\end{tabular}


Appendix E: X-Ray Diffraction Analysis 


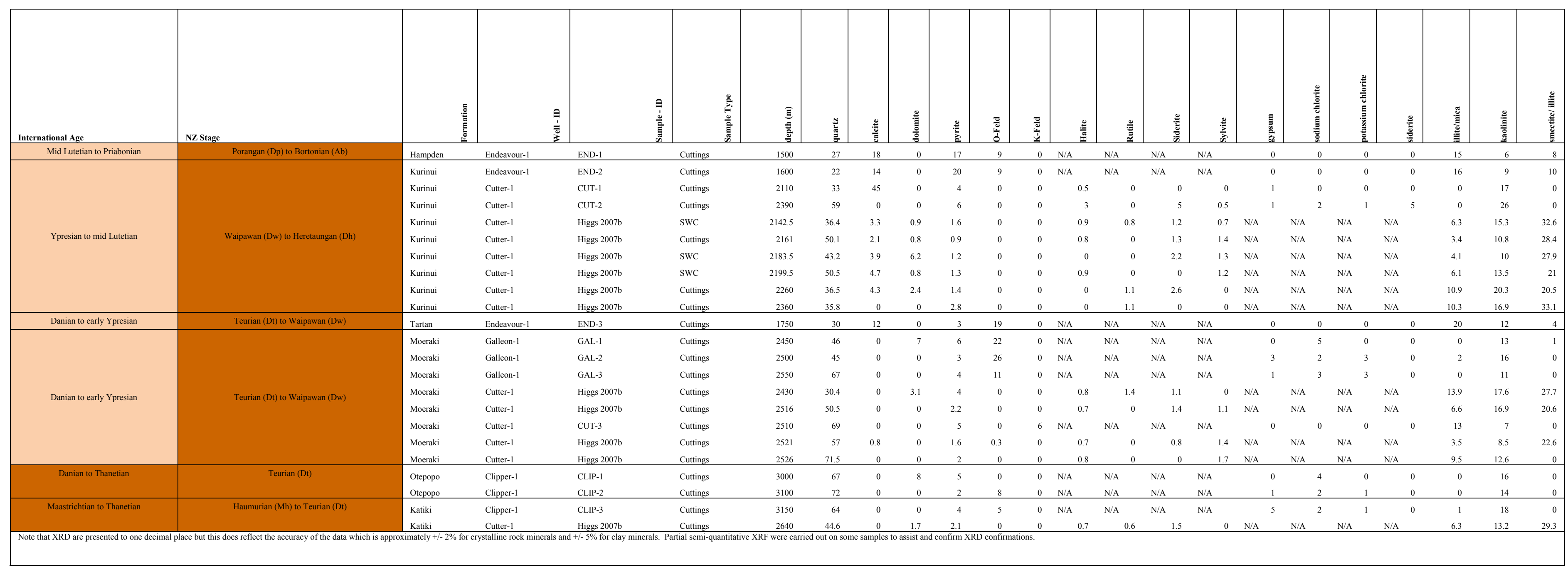




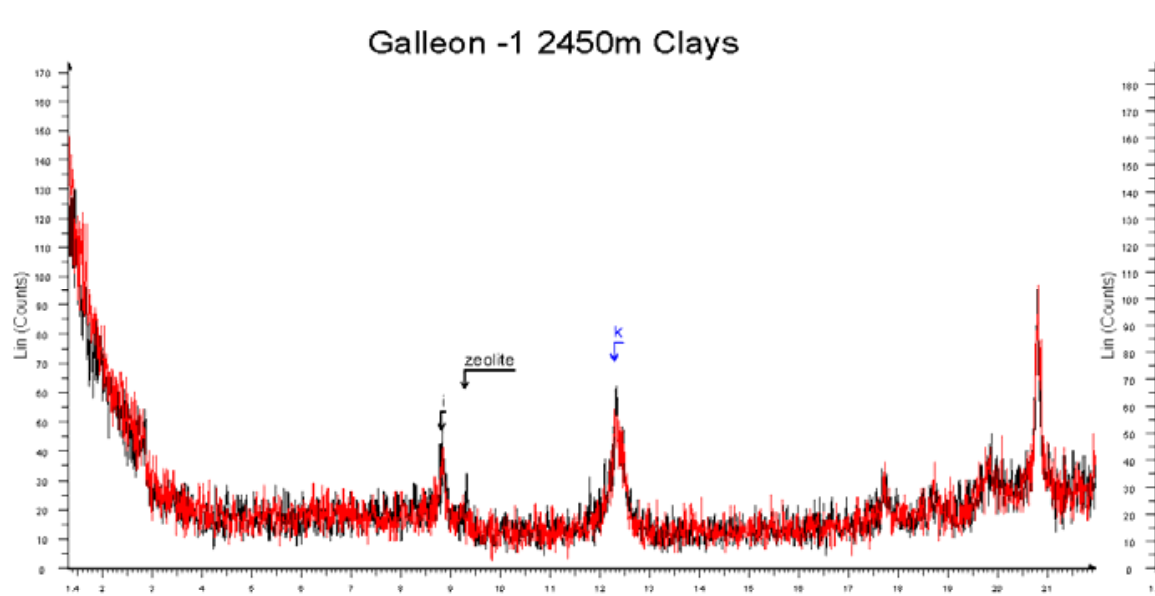

Galleon-1 2500m Clays

Galleon-1 2550m Clays
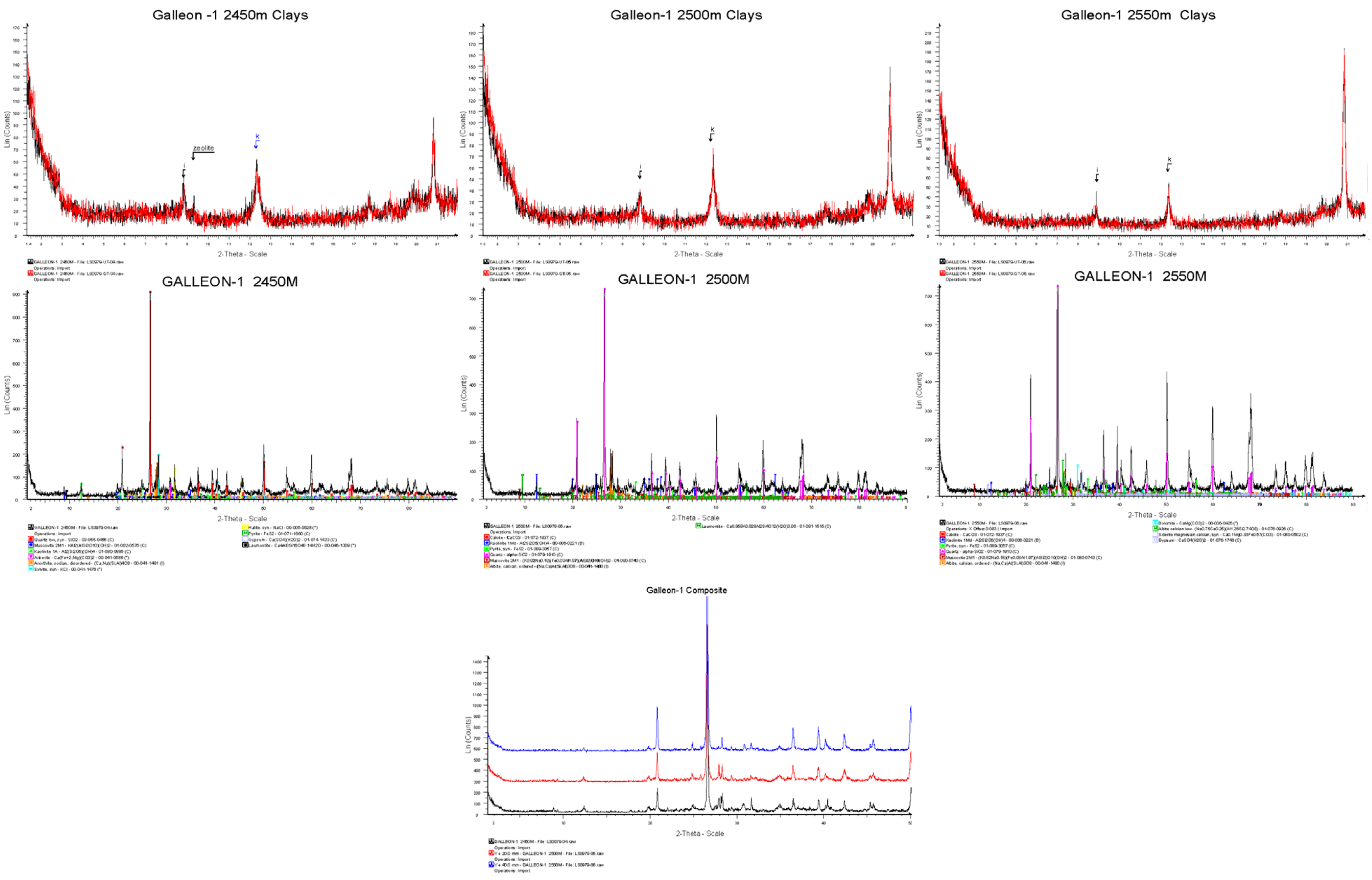


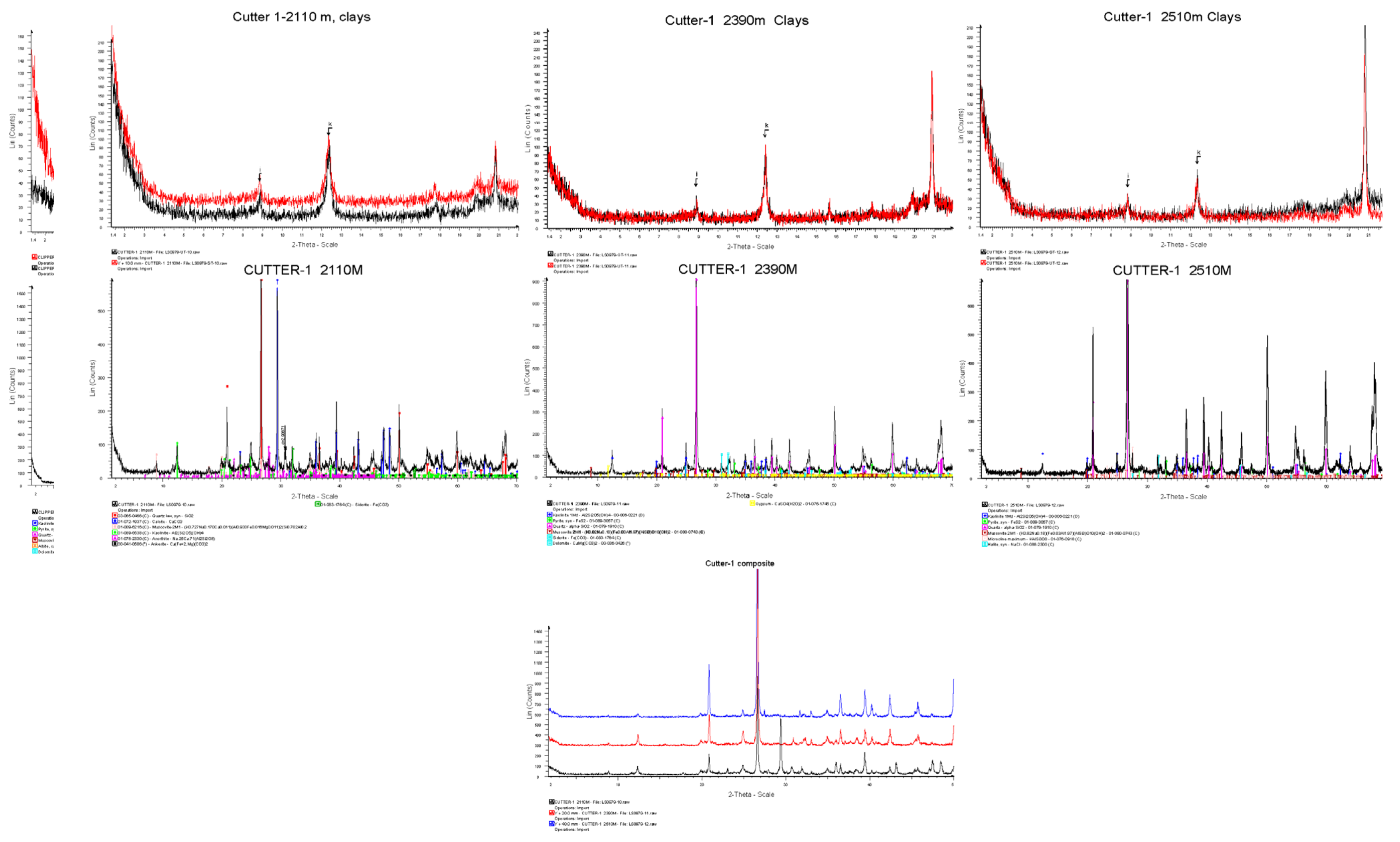


Appendix F: Scanning Electron Microscopy \& Energy Dispersive Spectroscopy Analysis 


\section{Clipper-1 3000 mbrt. Back Scattered Image 17000 x mag}
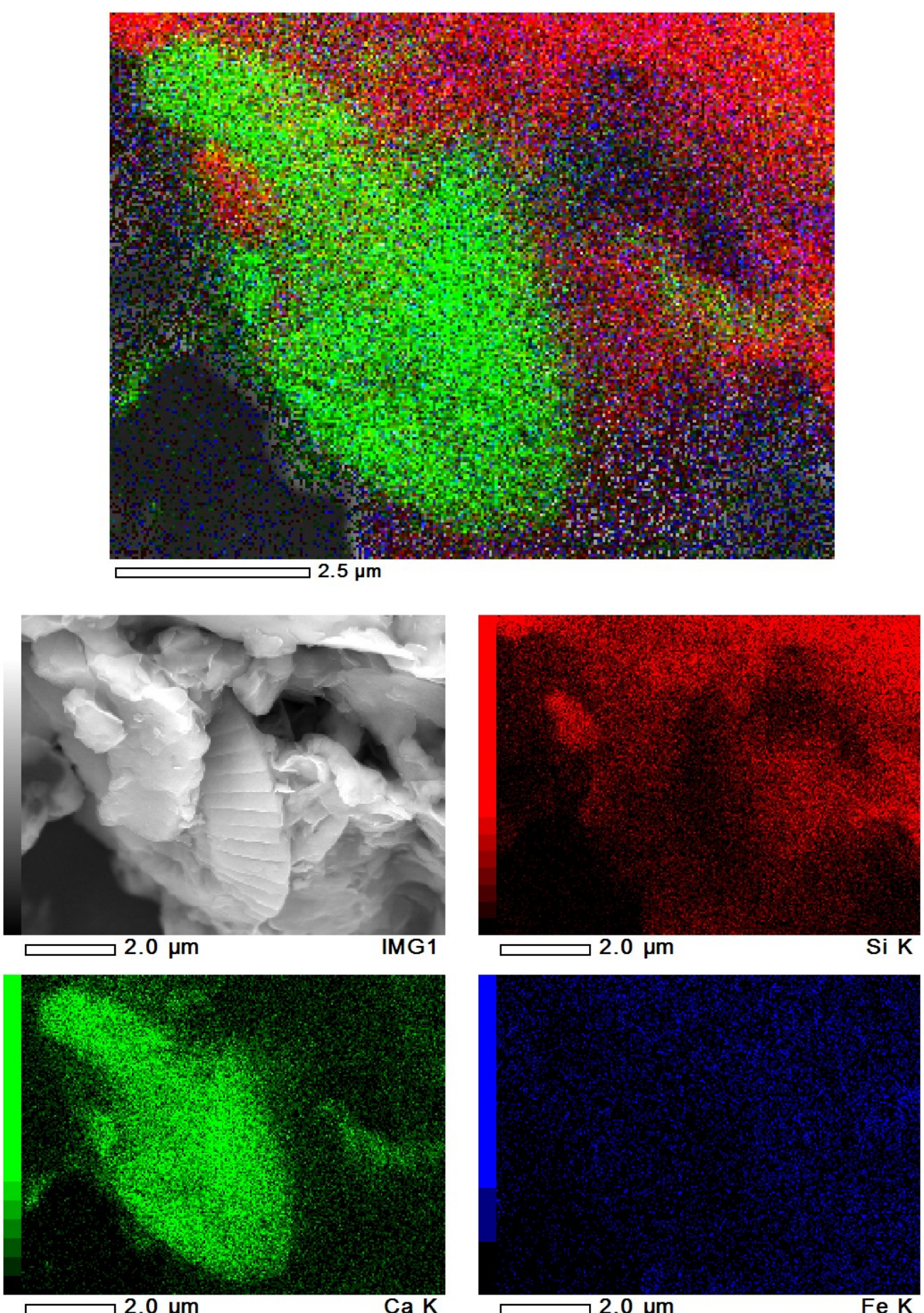

JEOL 
Clipper-1 3000 mbrt. Back Scattered Image 17000 x mag
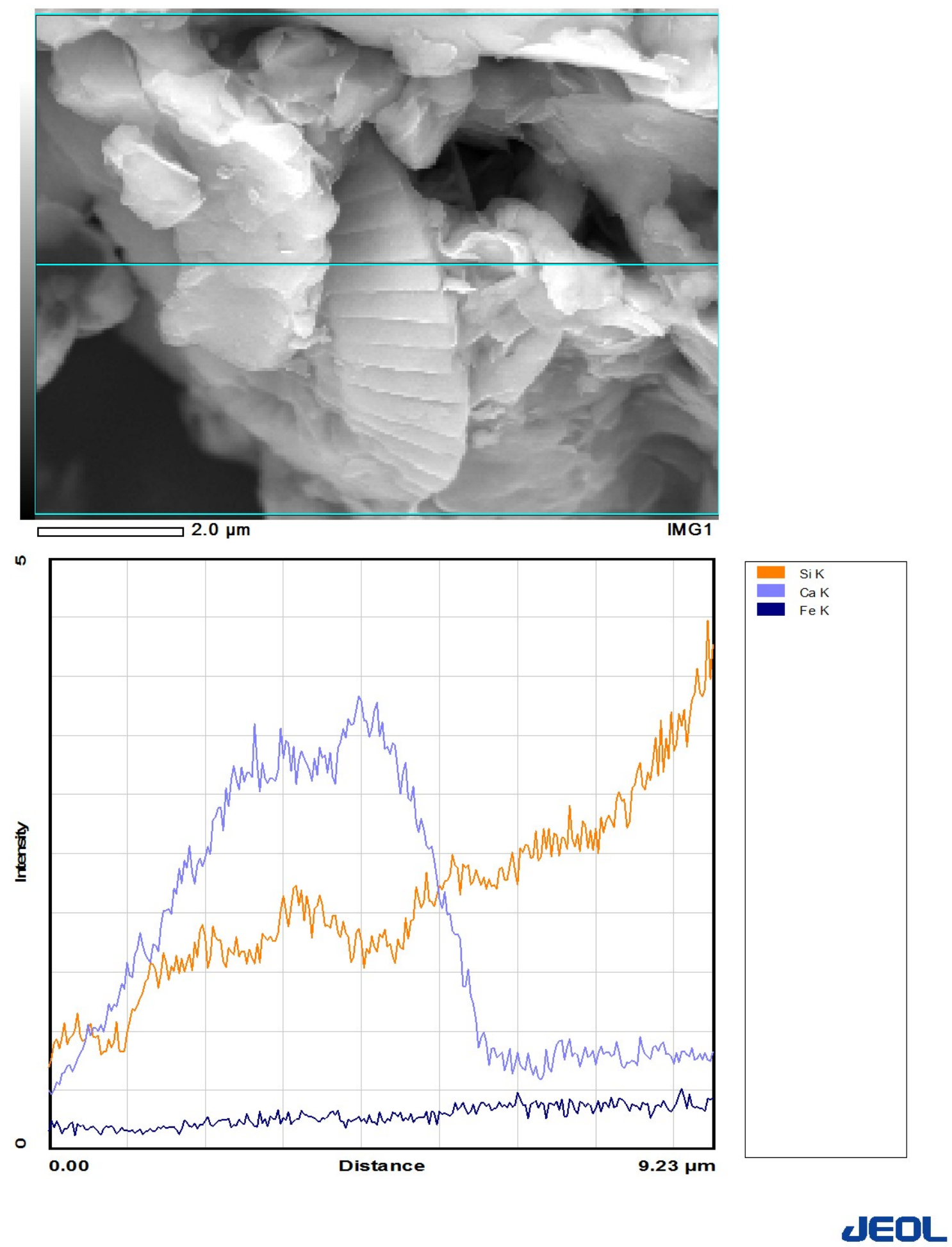


\section{Clipper-1 3150 mbrt. Back Scattered Image 17000 x mag}
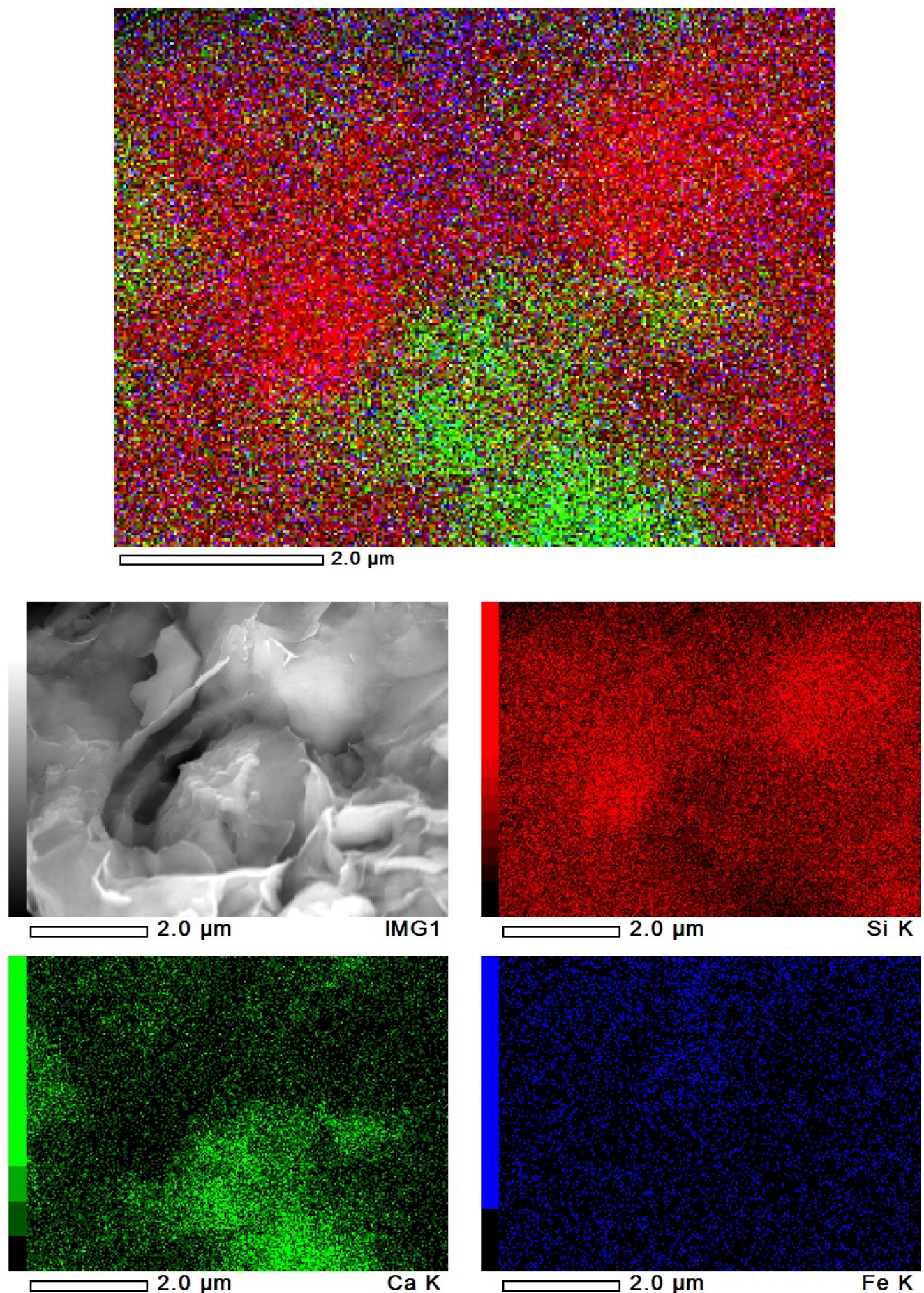

JEOL 
Clipper-1 3150 mbrt. Back Scattered Image 17000 x mag
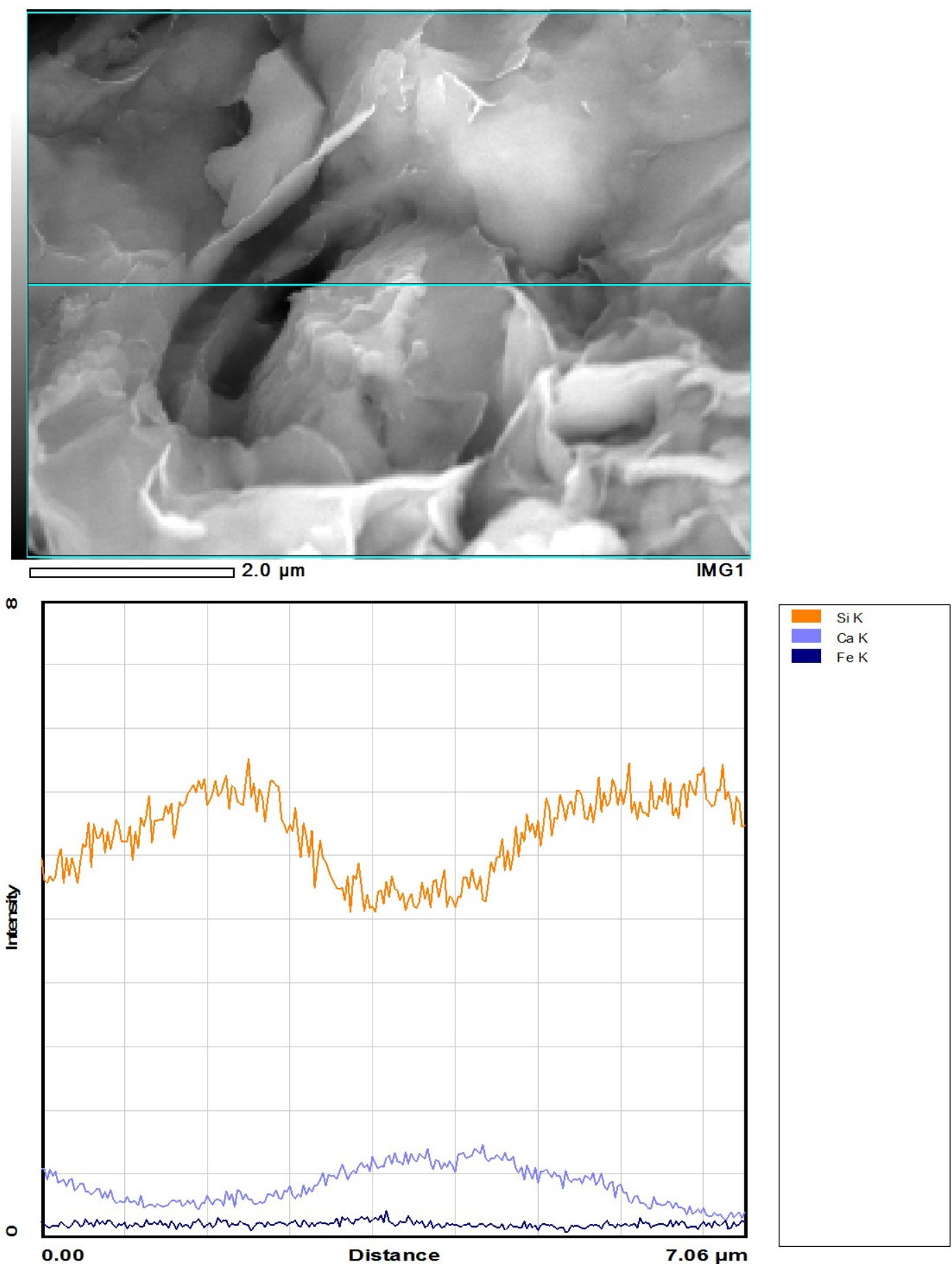

JEOL 


\section{Endeavour-1 1900 mbrt. Back Scattered Image 7500 x mag}


JEOL 
Appendix G: Rock Evaluation Pyrolysis 


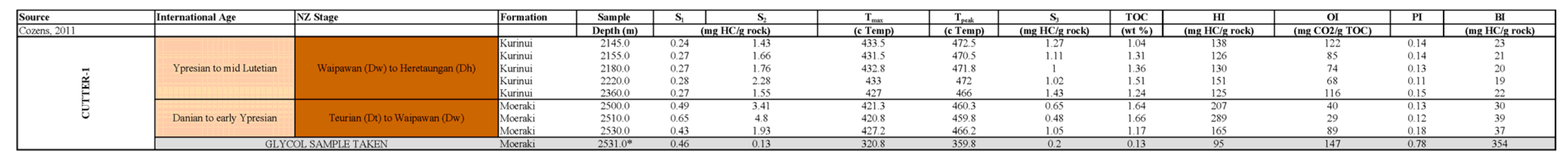

\begin{tabular}{|c|c|c|c|c|c|c|c|}
\hline $\begin{array}{l}\text { Source } \\
\text { Gibbons \& Fry (1986) }\end{array}$ & International Age & NZ Stage & Formation & \begin{tabular}{|c|} 
Sample \\
Depth (m)
\end{tabular} & $\begin{array}{l}\text { TOC } \\
(\text { wt \% } \%)\end{array}$ & $\begin{array}{c}\mathrm{HI} \\
\text { (mg HC/g rock) }\end{array}$ & $\frac{\mathbf{S}_{2}}{\text { (mg HClg rock) }}$ \\
\hline \multirow{16}{*}{ 竞 } & Mid Lutetian to Priabonian & Porangan (Dp) to Bortonian (Ab) & $\begin{array}{l}\text { Hampden } \\
\text { Hampden }\end{array}$ & $\begin{array}{l}1914.4 \\
19200\end{array}$ & 0.63 & $\begin{array}{r}190 \\
182 \\
\end{array}$ & $\begin{array}{l}1.2 \\
08\end{array}$ \\
\hline & \multirow{8}{*}{ Ypresian to mid Lutetian } & \multirow{8}{*}{ Waipawan (Dw) to Heretaungan (Dh) } & $\begin{array}{l}\text { Kurnui } \\
\text { Kurinui }\end{array}$ & $\begin{array}{ll}2010.0 \\
21000\end{array}$ & $\begin{array}{l}0.31 \\
0.33\end{array}$ & $\begin{array}{ll}129 \\
303\end{array}$ & \\
\hline & & & $\begin{array}{l}\text { Kurinui } \\
\text { Kurnu }\end{array}$ & 2163.0 & 0.49 & 347 & \\
\hline & & & $\begin{array}{l}\text { 甚urinui } \\
\text { Kurinui }\end{array}$ & $\begin{array}{l}2197.6 \\
2190.0\end{array}$ & $\begin{array}{l}0.61 \\
0.57\end{array}$ & $\begin{array}{l}344 \\
175\end{array}$ & \\
\hline & & & 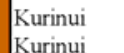 & 2220.0 & & & \\
\hline & & & 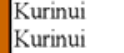 & 2259.1 & $\begin{array}{l}0.51 \\
0.51\end{array}$ & $\begin{array}{l}333 \\
78\end{array}$ & 0 \\
\hline & & & $\begin{array}{l}\text { Kurinui } \\
\text { Kurinui }\end{array}$ & 22280.6 & $\begin{array}{l}0.41 \\
0.32\end{array}$ & & \\
\hline & & & $\begin{array}{l}\text { Kurinui } \\
\text { Kunvi } \\
\end{array}$ & 2310.0 & 0.28 & 143 & 0 \\
\hline & & & 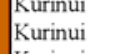 & 2381.6 & $\begin{array}{l}0.35 \\
2.2\end{array}$ & 268 & . \\
\hline & \multirow{8}{*}{ Danian to early Ypresian } & \multirow{8}{*}{ Teurian (Dt to Waipawan (Dw) } & $\begin{array}{l}\text { Surnin } \\
\text { Moers }\end{array}$ & $\frac{2306.3}{2370.0}$ & $\frac{1.3}{0.9}$ & 256 & 叀. \\
\hline & & & $\mid \begin{array}{l}\text { Moeraki } \\
\text { Mocerki }\end{array}$ & 2400.0 & 2.5 & 296 & $7.4 .42=$ \\
\hline & & & Meraki & & 0.88 & & 3 \\
\hline & & & $\begin{array}{l}\text { Moreraki } \\
\text { Mocraki }\end{array}$ & $\begin{array}{l}2430.0 \\
2440.0\end{array}$ & & $\begin{array}{l}354 \\
283\end{array}$ & 3. \\
\hline & & & $\mid \begin{array}{l}\text { Moeraki } \\
\text { Mocerki }\end{array}$ & 2474.6 & 1.8 & 250 & 4. \\
\hline & & & $\begin{array}{l}\text { Morerala } \\
\text { Moraki }\end{array}$ & 25020 & & & \\
\hline & & & Mocraki & 2519.5 & 1.8. & 100 & \\
\hline & & & & & & & \\
\hline \multirow{2}{*}{ CLIPPER-1 } & Ypresian to mid Lutetian & Waipawan (Dw) to Heretaungan (Dh) & $\begin{array}{l}\text { Kurinui } \\
\text { Kuriumi }\end{array}$ & $\begin{array}{l}2410.0 \\
2480\end{array}$ & $\begin{array}{c}0.2 \\
0.38\end{array}$ & $\begin{array}{c}\text { n/a } \\
105\end{array}$ & \\
\hline & Danian to arly Ypresian & Eurian (D) to Waipawan & $\begin{array}{c}\text { reaki } \\
\end{array}$ & & $\frac{177}{77}$ & & \\
\hline
\end{tabular}

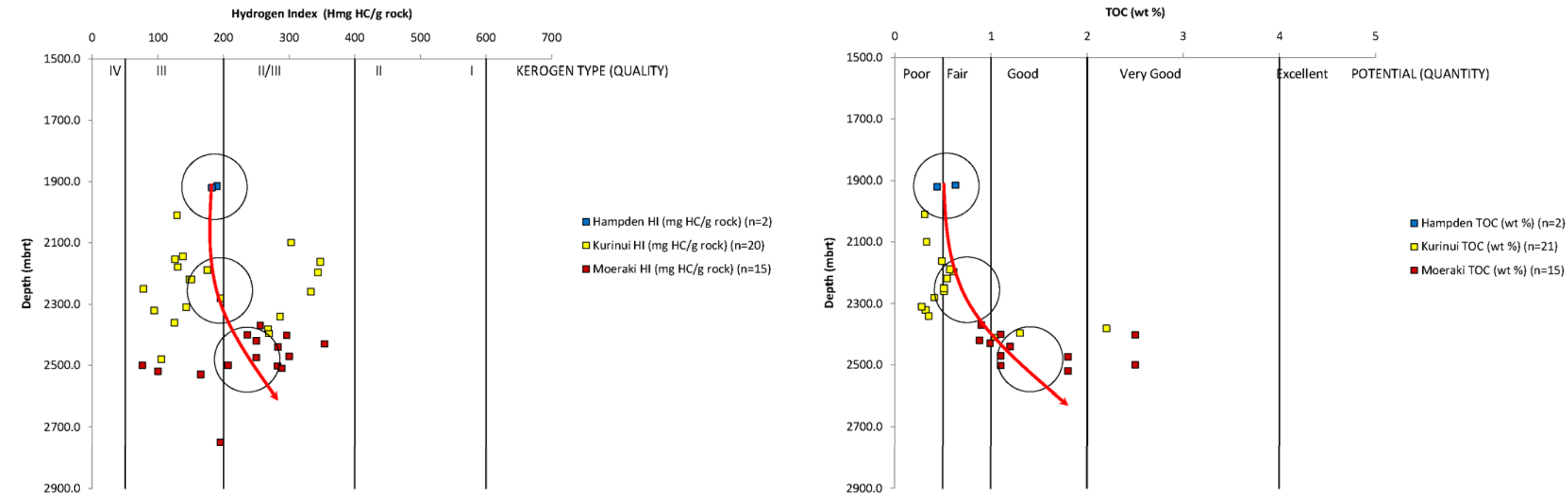

COMPOSITE CLIPPER SUB-BASIN CROSS PLOTS. KURINUI AND UNDERL YING MOERARI FORMATION INTERVALS PLOTTED DUE TO THE ELEVATED GAS CHROMATOGRAPH READINGS IN THESE FORMATIONS MADE DURING DRILLING OPERATIONS

GENERATIE POTENTAL (OLANTITY) AND KEROGEN TYPE- EXPELED PRODLCTS 
SR Analyzer (SRA -TOC) - TPH TOC Analysis v6.5.113

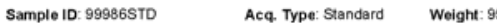

Depth: Date: December 18 2010/4:54:21 PM

Crucible: 2

Data C:ISRA JOBSISRA001A_Cutter-1_181210199986STD.RAW

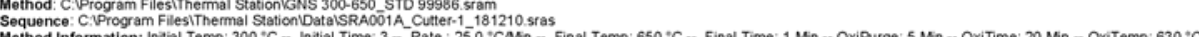

FID Temp: $325^{\circ} \mathrm{C}$
FID Gain: Low (1016)

Callibration Standard Information: Standard Name: 99986 tTemp: $457.0^{\circ} \mathrm{C} \quad$ PTPH (S2): $8.41 \mathrm{mg} / \mathrm{g} \quad$ S3: $0.39 \mathrm{mg} / \mathrm{g} \quad$ S4: $23.99 \mathrm{mg} / \mathrm{g}$

Temp: $: 675^{\circ} \mathrm{C}$
FID $45.62 \mathrm{mV}$
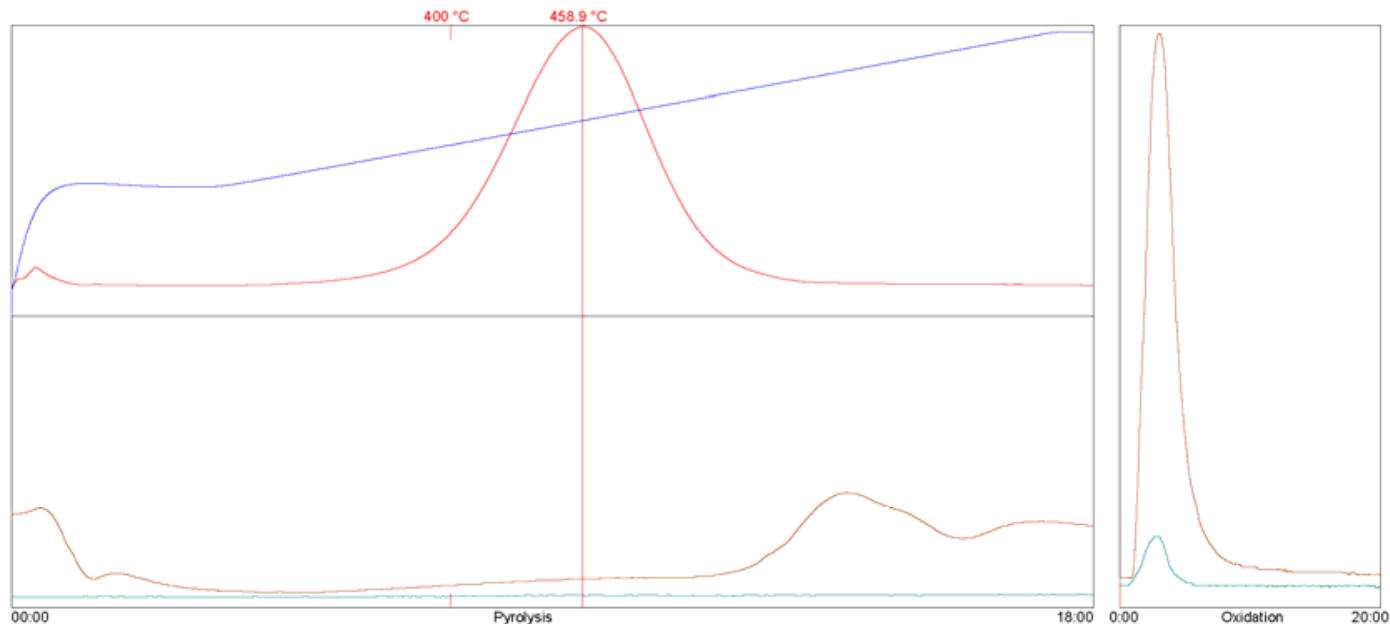

FID Response: $9.26 \mathrm{E}+7$ Temperature Offset- $-1.9^{\circ} \mathrm{C}$ IR S3 Response:224E+8 IR S4 Response:6.44E+8

Monday, 20 December 2010 14:07:20

SR Analyzer (SRA -TOC) - TPH TOC Analysis v6.5.113

$\begin{array}{llll}\text { Sample 1D: } 99986 & \text { Acq. Type: TPH Weight: } 98.5 & \text { Crucible: } 3\end{array}$

Acq. Date: December 18 2010/5:47:06 PM

Data CISRA JOBSISRA001A_Cutter-1_181210199986.RAW

Method: C.P. Program Filestithermal StationiGNS 300-650_STD 99986. stam

Method Information: Intilial Temp: $300^{\circ} \mathrm{C}$ - Intilial Time: 3 - Rate : $25.0^{\circ} \mathrm{CMMn}$ - Final Temp: $650^{\circ} \mathrm{C}$ - Final Time: 1 Min -. OxiPurge: 5 Mn - OxiTime: 20 Min - OxiTemp: 630 ${ }^{\circ} \mathrm{C}$ FID Temp: $325^{\circ} \mathrm{C}$.
FID Galn: Low (1006)

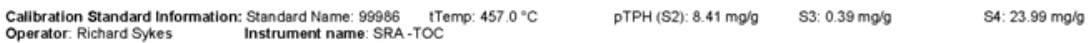

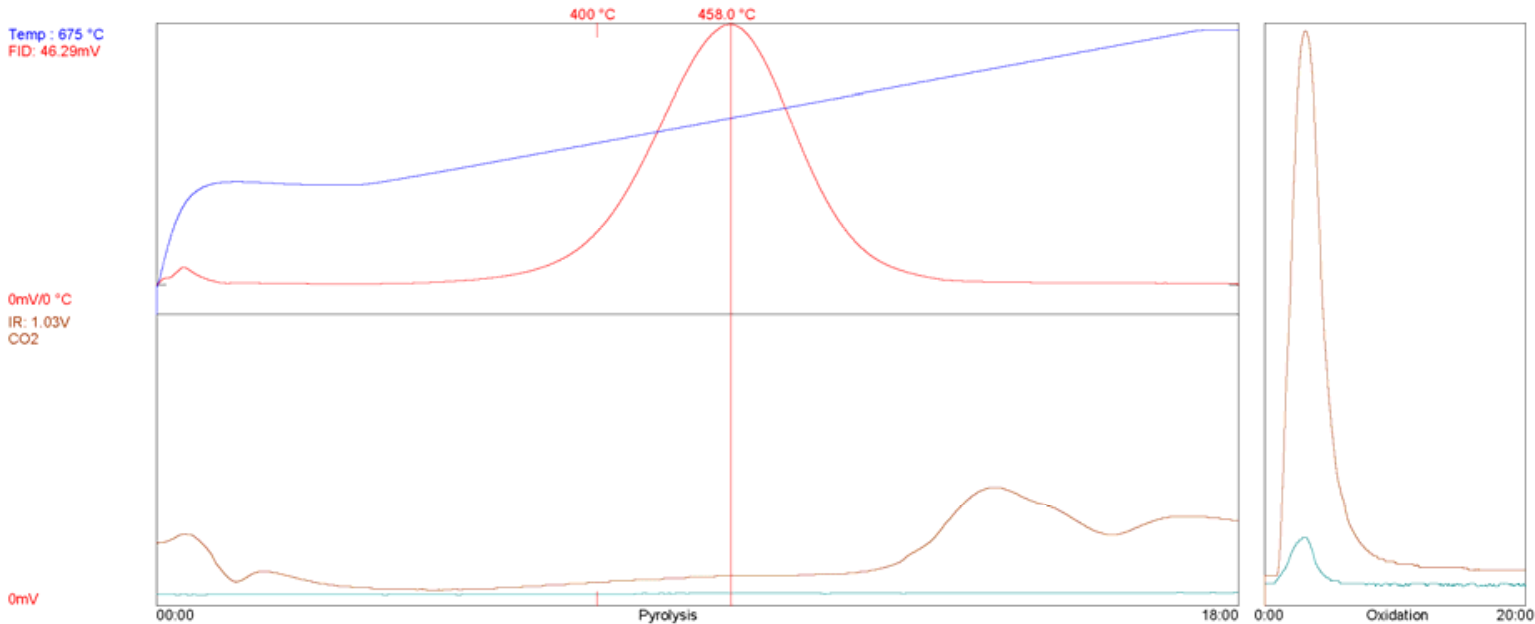

VTPH(S1):12mg/g PTPH(S2): 8.27mg/g cTemp(Tmax): $419.00^{\circ} \mathrm{C}$ tTemp:458.0 $0^{\circ} \mathrm{C}$ S3.40mg/g TOC:3.12\% HI:265 Ol:13 Pl:0.01 S1/TOC:0.04

Monday, 20 December 2010 14:08:03 
SR Analyzer (SRA -TOC) - TPH TOC Analysis v6.5.113

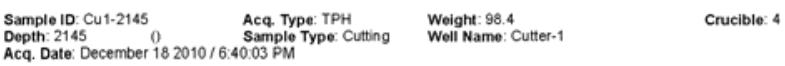

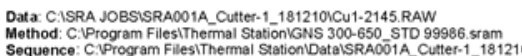

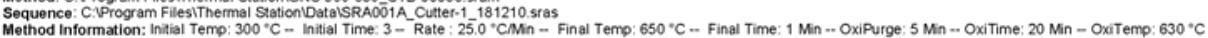
FID Temp: $325^{\circ} \mathrm{C}$
FID Gain: Low (1016)

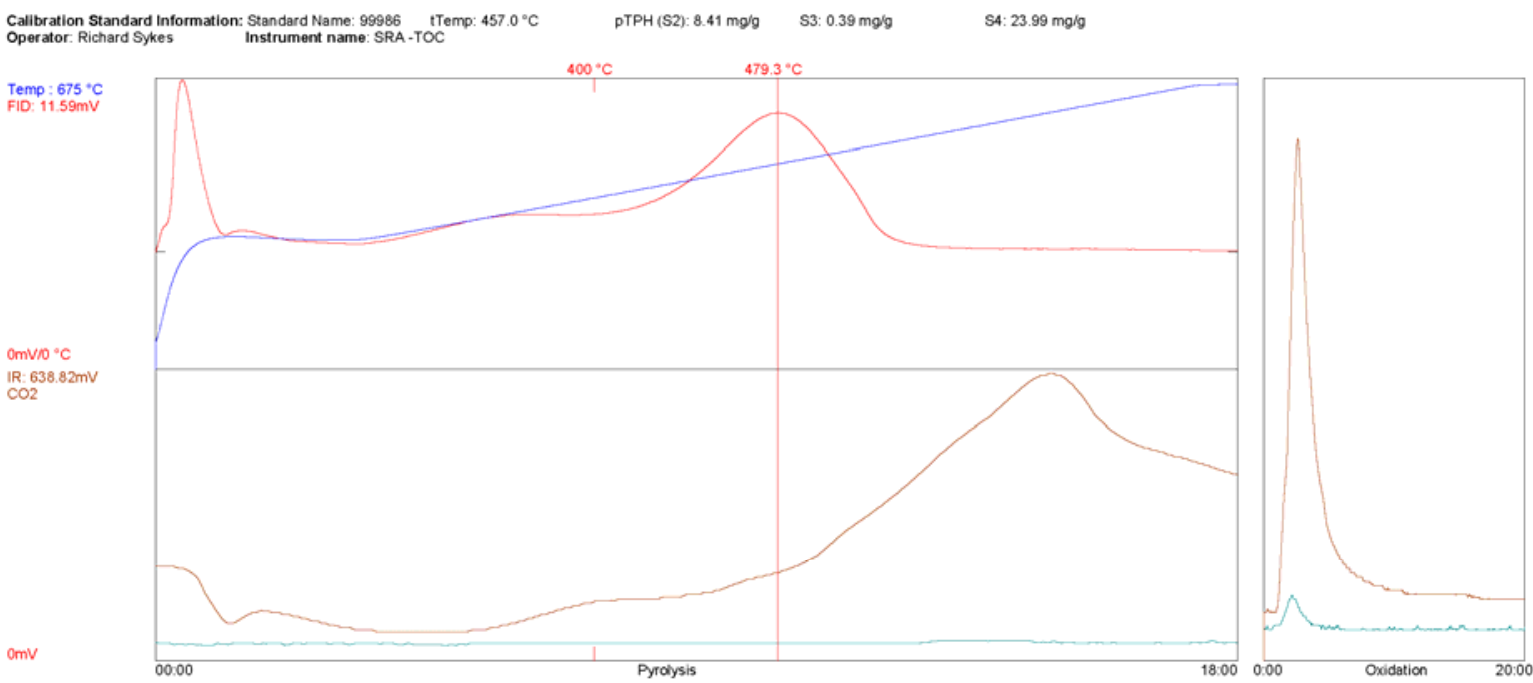

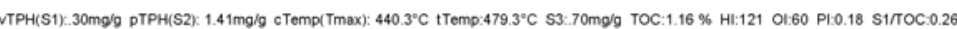

SR Analyzer (SRA -TOC) - TPH TOC Analysis v6.5.113
Sample ID: Cu1-2155
Depth: 2155
Acq. Type: TPH
Woight: 97.1 Cutter-1
Woll Name Cutter
Crucible: 5

Data C:ISRA JOBSTSRA001A_Cutter-1_1812101CU1-2155.RAW

Method: C:Program FilesiThermal StationiGNS 300-650_STD 99986.sram

Method Information: Intilial Temp: $300^{\circ} \mathrm{C}$ - Intilial Time: 3 - Rate : $25.0^{\circ} \mathrm{CM}$ - Final Temp: $650^{\circ} \mathrm{C}$ - Final Time: 1 Min -. OxiPurge: 5 Mn - OxiTime: 20 Min - OxiTemp: $630^{\circ} \mathrm{C}$ FID Temp: $325^{\circ} \mathrm{C}$
FID Gain: Low (10,9)

$\begin{aligned} & \text { Callbration Standard Information: Standard Name: } 99986 \\ & \text { Operator. Richard Sykes }\end{aligned}$ Temp: $457.0^{\circ} \mathrm{C}$
Instrument name: SRA.TOC

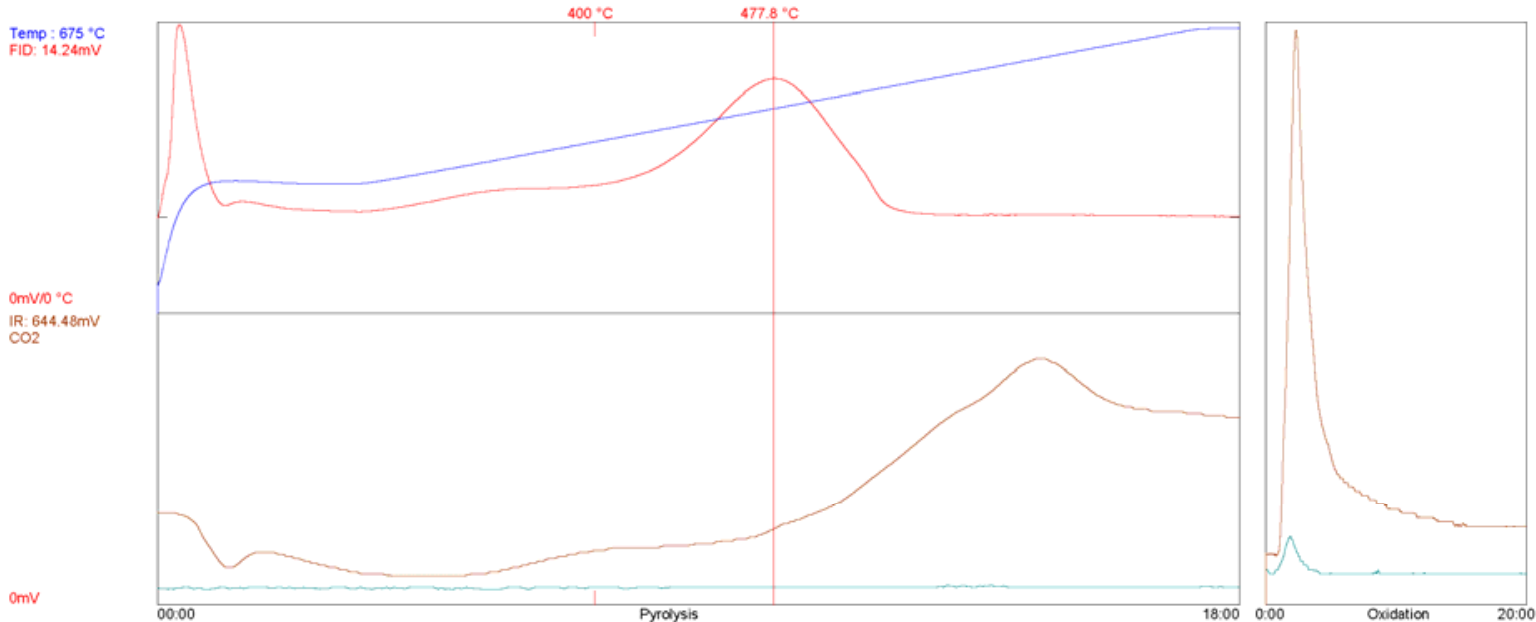

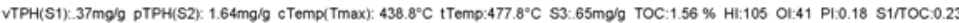

Monday, 20 December 2010 14:10:05 
SR Analyzer (SRA -TOC) - TPH TOC Analysis v6.5.113

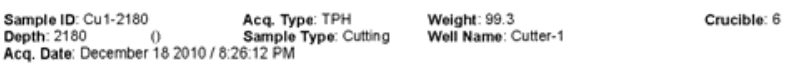

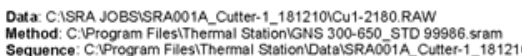

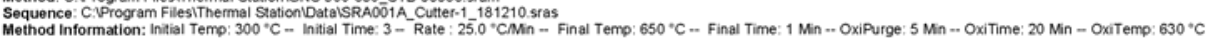
FID Temp: $325^{\circ} \mathrm{C}$
FID Gain: Low (1016)

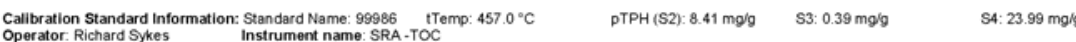

Temp: $: 675^{\circ} \mathrm{C}$
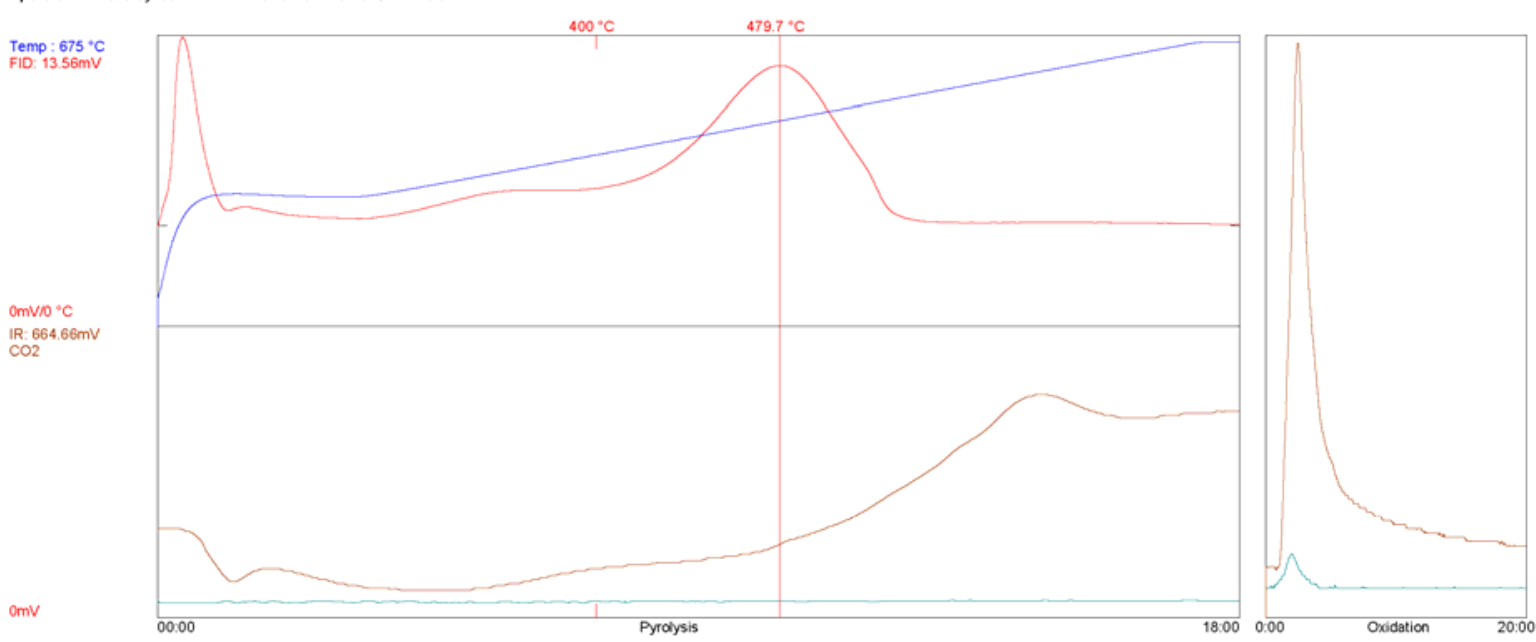

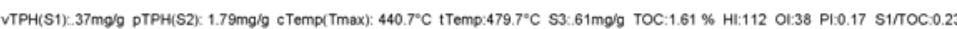

SR Analyzer (SRA -TOC) - TPH TOC Analysis v6.5.113
Sample ID: Cu1-2220
Depth: 2220
Acq. Type: TPH
Weight: 97.2
Crucible: 7

Data C:ISRA JOBSTSRA001A_Cutter-1_1812101CU1-2220.RAW

Method: C:Program FilesiThermal StationiGNS 300-650_STD 99986.stam

Method Information: Intilial Temp: $300^{\circ} \mathrm{C}$ - Intilial Time: 3 - Rate : $25.0^{\circ} \mathrm{CMMn}$ - Final Temp: $650^{\circ} \mathrm{C}$ - Final Time: 1 Min -. OxiPurge: 5 Mn - OxiTime: 20 Min - OxiTemp: $630^{\circ} \mathrm{C}$ FID Temp: $325^{\circ} \mathrm{C}$

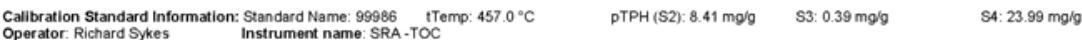

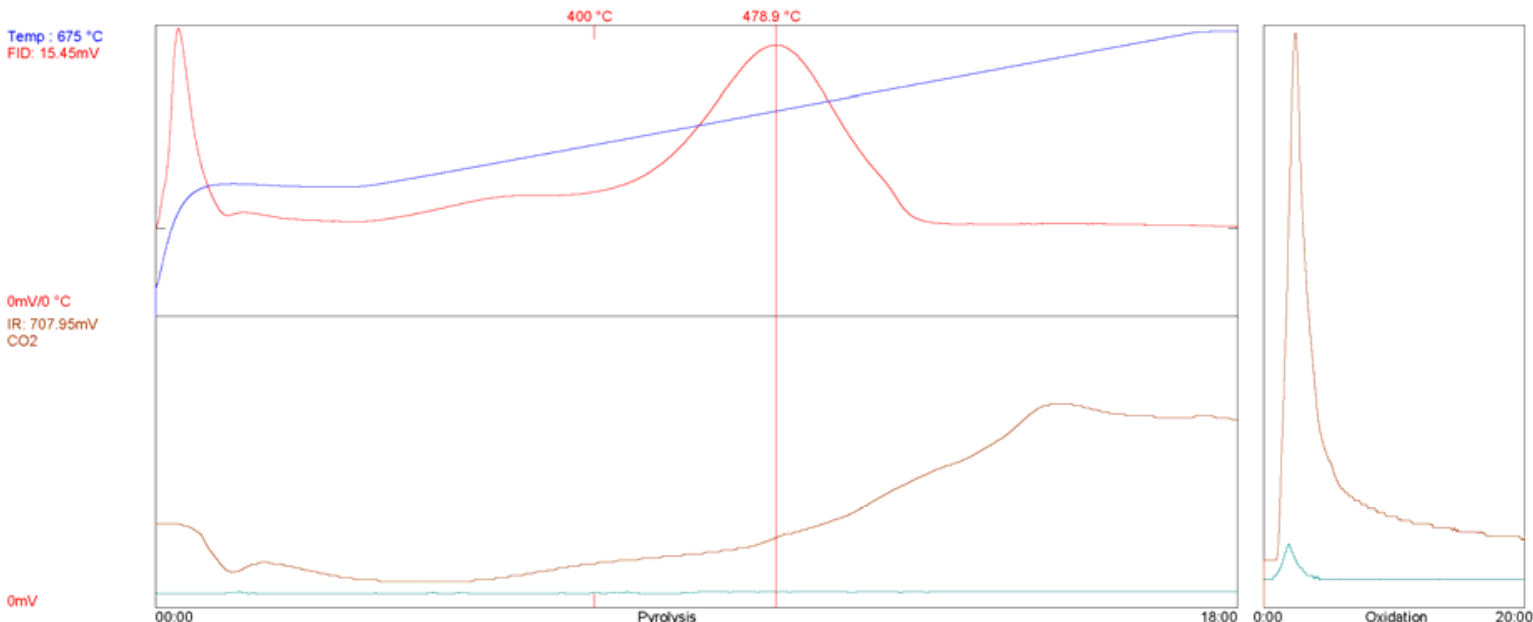

VTPH(S1) $41 \mathrm{mg} / \mathrm{g}$ PTPH(S2): $234 \mathrm{mg} / 9$ cTemp(Tmax): $439.9^{\circ} \mathrm{C}$ tTemp. $478.9^{\circ} \mathrm{C}$ S3.61mg/g TOC: $1.77 \%$ HI: 132 Ol:34 Pl:0.15 S1/TOC 0.23

Monday, 20 December 2010 14:11:30 
SR Analyzer (SRA -TOC) - TPH TOC Analysis v6.5.113

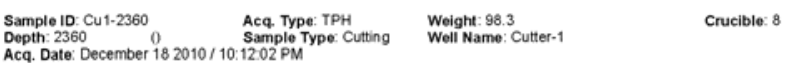

Data CISRA JOBSISRA001A_Cutter-1_1812101CU1-2360.RAW

Method: C:Program Files:Themal StationlGNS 300-650 STD 99986.sram

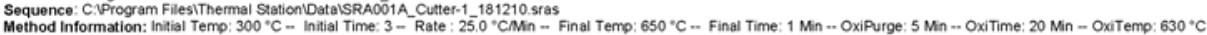
MiD Temp: $325^{\circ} \mathrm{C}$

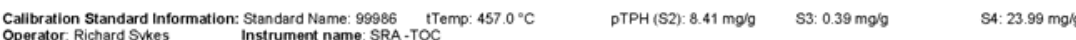

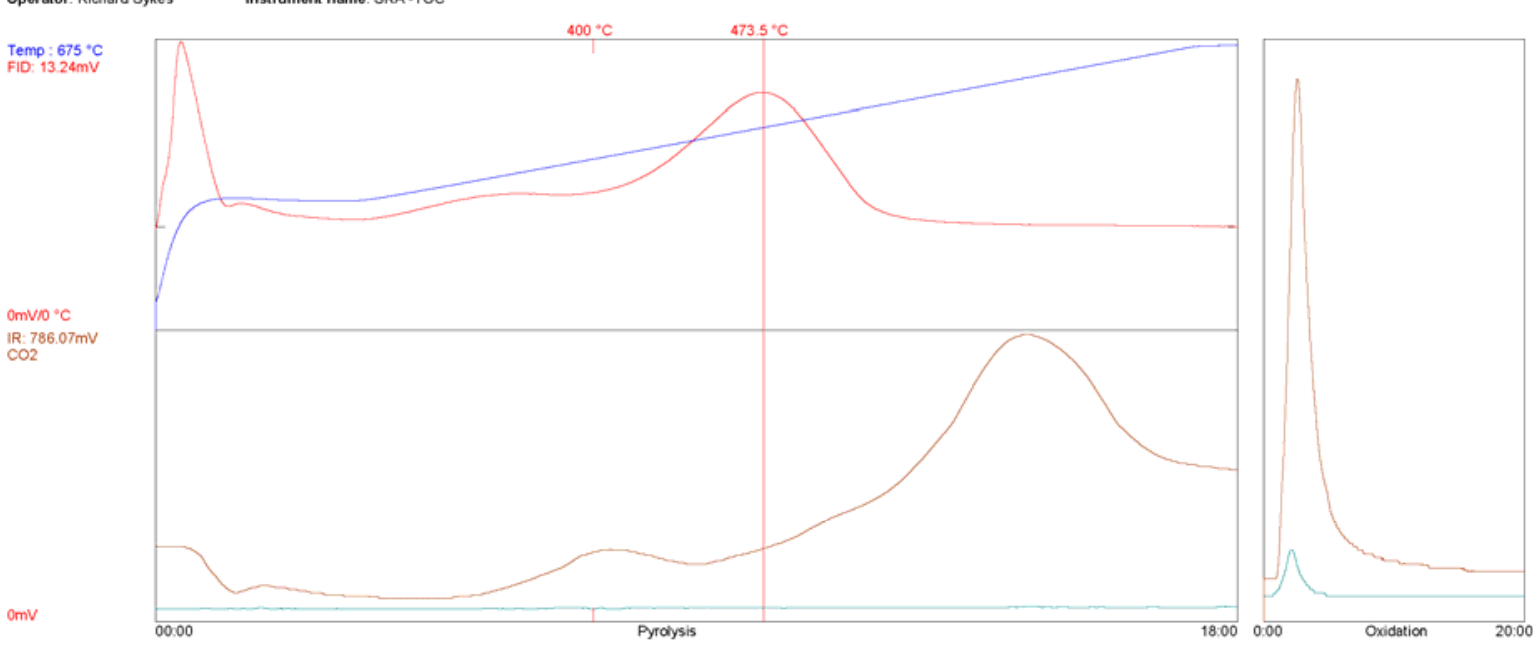

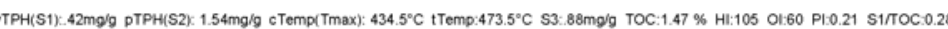

SR Analyzer (SRA -TOC) - TPH TOC Analysis v6.5.113
Sample ID: Cu1-2500
Acq. Type. TPH
Weight: 100.8
Crucible: 9
Acq. Date December 18 2010/11:04:58 PM

Data CISRA JOBSISRA001A_Cutter-1_1812101Cu1-2500.RAW

Method: C:Program Filesithermal StationiGNS 300-650_STD 99986.sram

Method Information: Intial Temp: $300^{\circ} \mathrm{C}$ - Initial Time: 3 - Rate : $25.0^{\circ} \mathrm{CM}$ - Final Temp: $650^{\circ} \mathrm{C}$ - Final Time: 1 Min -. OxiPurge: 5 Mn - OxiTime: 20 Min - OxiTemp: $630^{\circ} \mathrm{C}$ FID Temp: $325^{\circ} \mathrm{C}$
FID Gain: Low (1009)

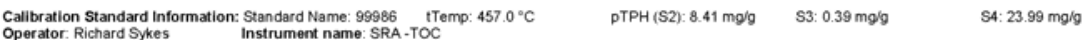

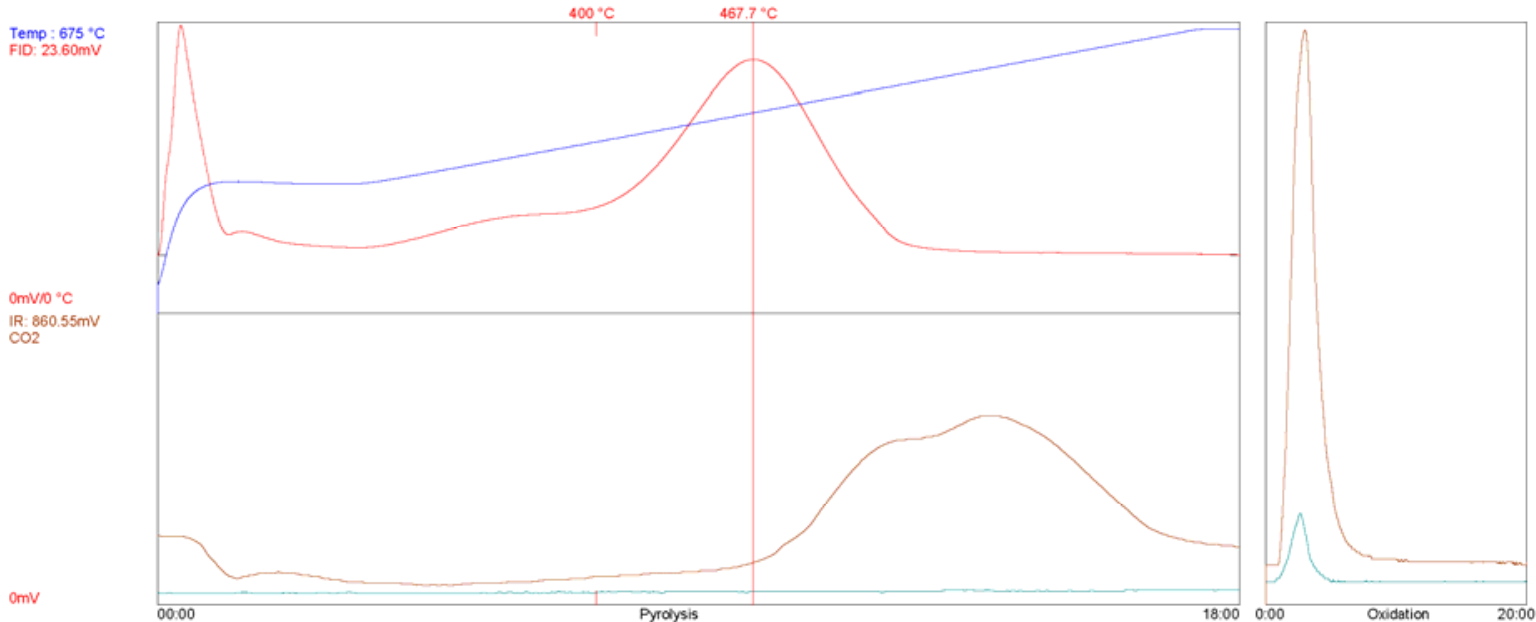

VTPH(S1): $82 \mathrm{mg} / \mathrm{g}$ PTPH(S2) $3.76 \mathrm{mg} / \mathrm{g}$ cTemp(Tmax): $428.7^{\circ} \mathrm{C}$ tTemp: $467.7^{\circ} \mathrm{C}$ S3. $42 \mathrm{mg} / \mathrm{g}$ TOC: $1.91 \%$ HI: 197 Ol:22 Pl0.18 S1/TOC 0.43

Monday, 20 December 2010 14:12:53 
SR Analyzer (SRA -TOC) - TPH TOC Analysis v6.5.113

$\begin{array}{llll}\text { Sample 10: Cu1-2510 } & \text { Acq. Type: TPH } & \text { Weight: } 94.1 & \text { Crucible: } 10 \\ \text { Dopth } 2510 & \text { Sample Type: Cutting } & \text { Well Name: Cutter-1 } & \\ \text { Acq. Date. December } 182010 / 11: 58: 00 \text { PM } & & \end{array}$

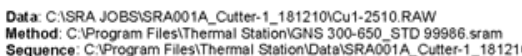

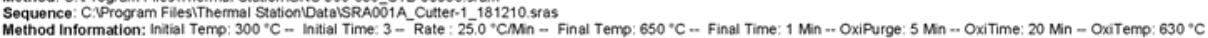
FID Temp: $325^{\circ} \mathrm{C}$
FID Gain: Low (1016)

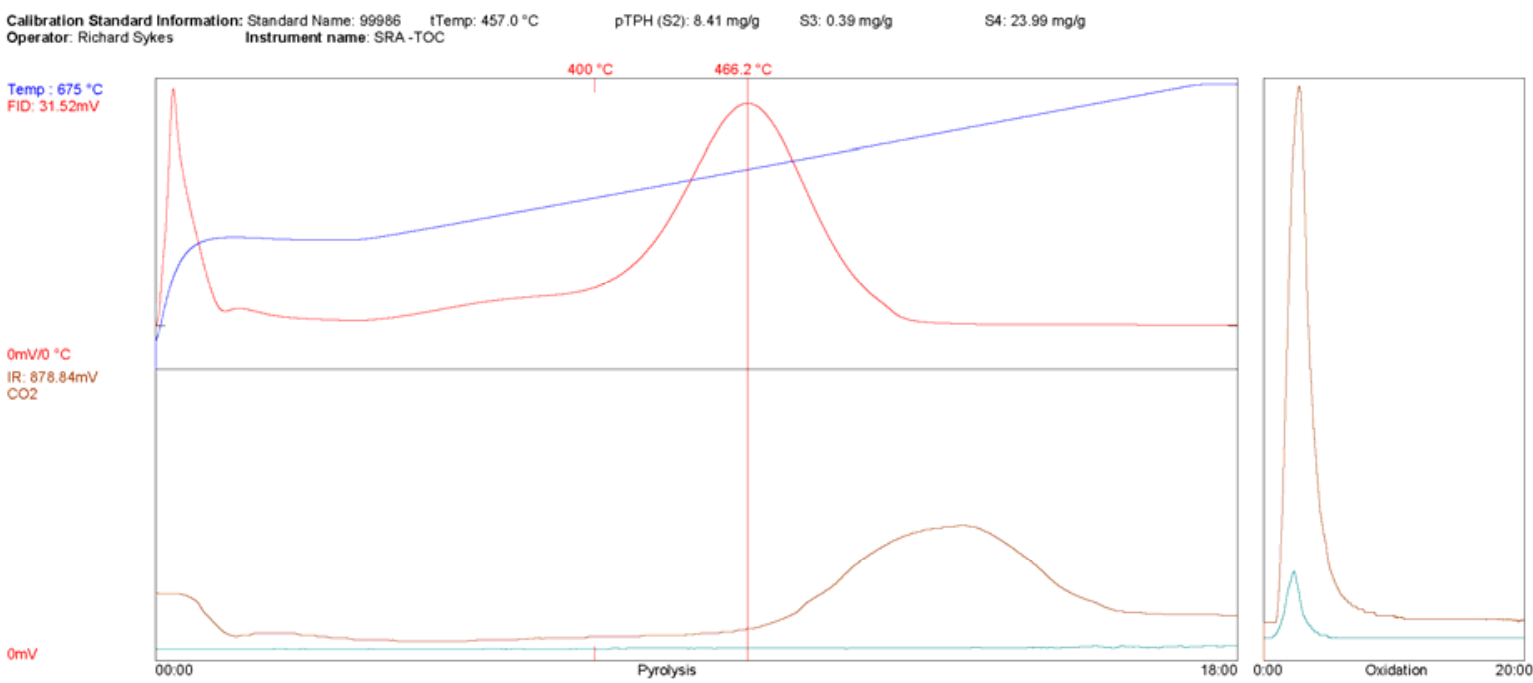

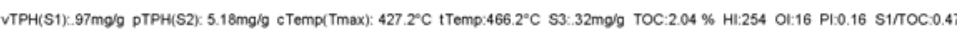

SR Analyzer (SRA -TOC) - TPH TOC Analysis v6.5.113
Sample ID: Cu1-2530
Depth: 2530 - 2530 .
Acq. Type: TPH
Weight: 95.1
Well Name: Cutter-1
Crucible: 11
Acq. Date December 19 2010/12:50:59 AM

Data C:ISRA JOBSISRA001A_Cutter-1_1812101Cu1-2530.RAW

Method: C:Program Filesithermal StationiGNS 300-650_STD 99986.sram

Method Information: Intilial Temp: $300^{\circ} \mathrm{C}$ - Intilial Time: 3 - Rate : $25.0^{\circ} \mathrm{CM}$ - Final Temp: $650^{\circ} \mathrm{C}$ - Final Time: 1 Min -. OxiPurge: 5 Mn - OxiTime: 20 Min - OxiTemp: $630^{\circ} \mathrm{C}$ FID Temp: $325^{\circ} \mathrm{C}$

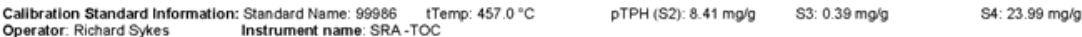

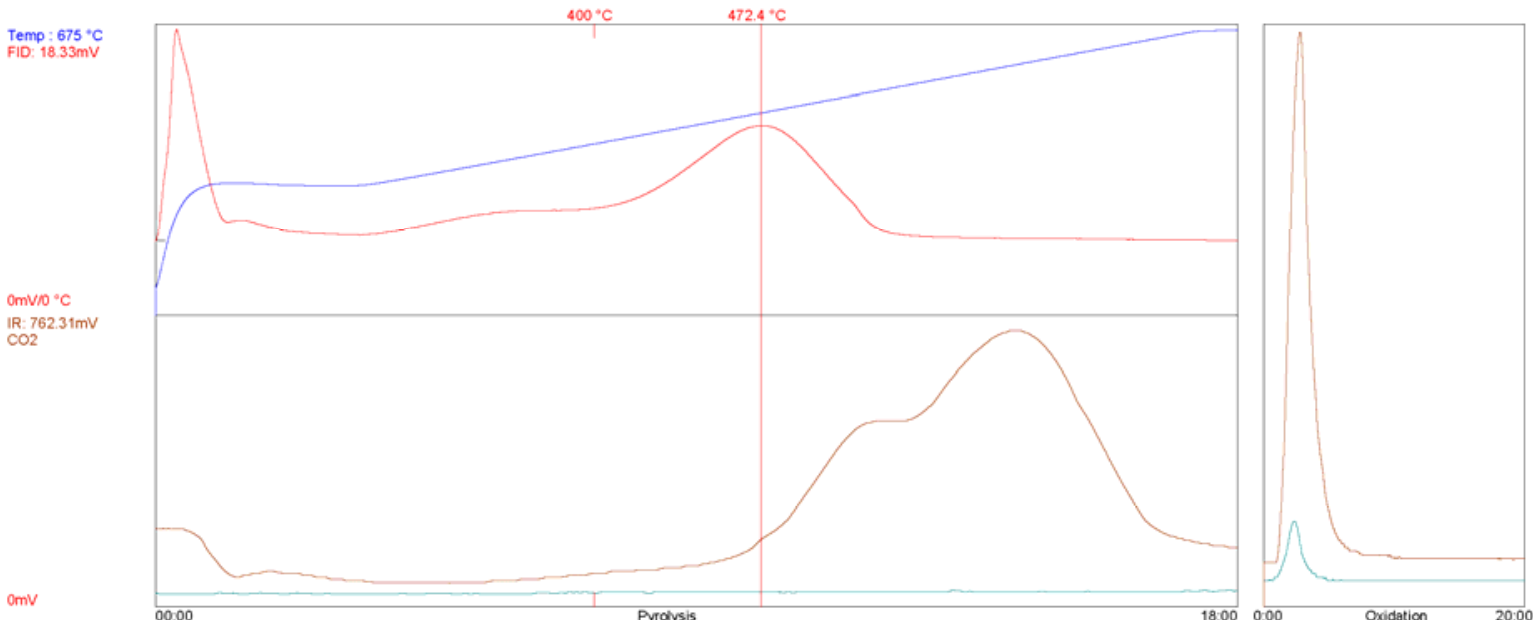

VTPH(S1) $62 \mathrm{mg} / \mathrm{p}$ PTPH(S2) $1.92 \mathrm{mg} / \mathrm{g}$ cTemp(Tmax): $433.4^{\circ} \mathrm{C}$ tTemp $4724^{\circ} \mathrm{C}$ S3. $52 \mathrm{mg} / \mathrm{g}$ TOC: $1.41 \%$ Hl:136 Ol:37 Pl: 0.24 S1/TOC. 0.43

Nonday, 20 December 2010 14:14:19 
SR Analyzer (SRA -TOC) - TPH TOC Analysis v6.5.113

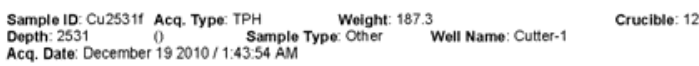

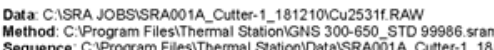

Sequence: C.Program FilesiThermal Station DataiSRA001A_Cutter-1_181210.sras

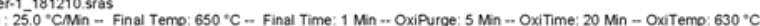

FID Temp: $325^{\circ} \mathrm{C}$
FID Gain: Low (1006)

$\begin{aligned} & \text { Callbration Standard Information: Standard Name: } 99986 \\ & \text { Operator. Richard Sykes }\end{aligned}$ TTemp: $457.0^{\circ} \mathrm{C}$
Instrument name SRA.TOC

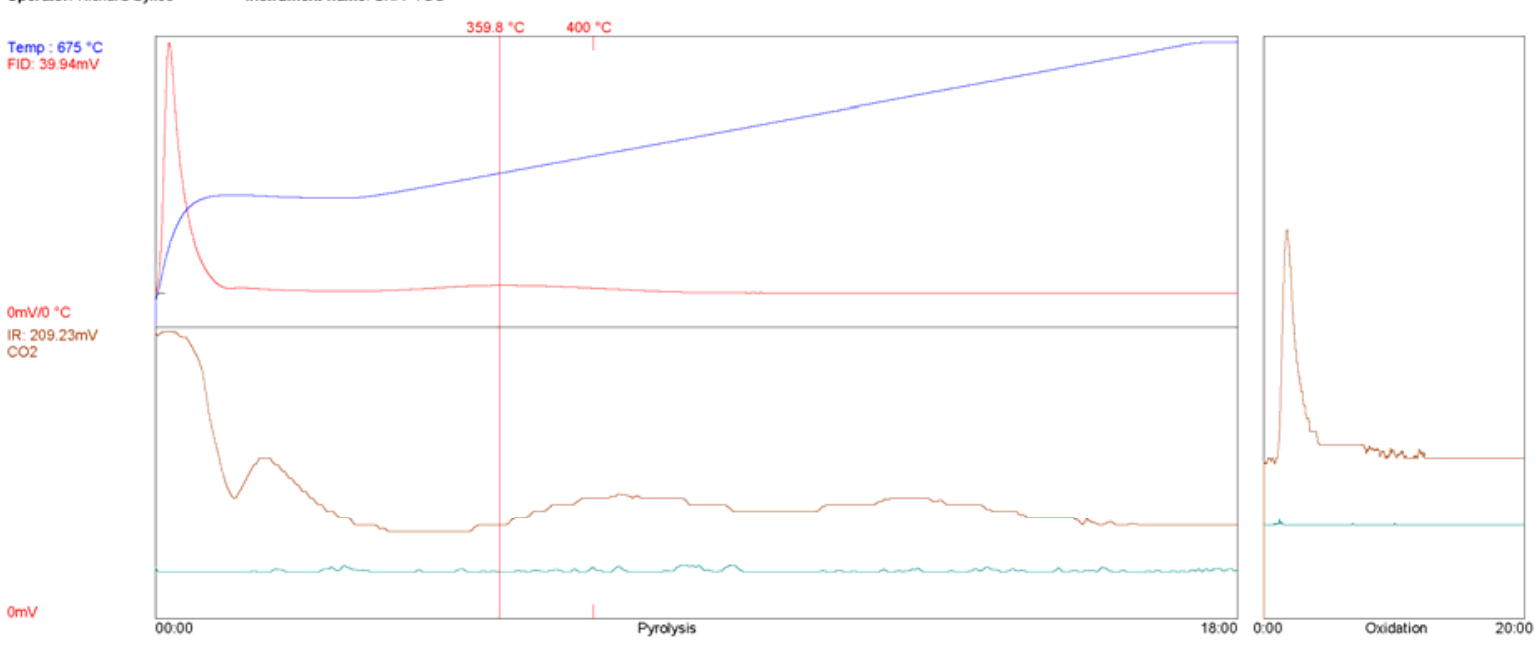

VTPH(S1).46mg/g PTPH(S2) . $13 \mathrm{mg} / 9$ cTemp(Tmax): $320.8^{\circ} \mathrm{C}$ tTemp:359.8 $8^{\circ} \mathrm{C}$ s3:20mg/g TOC:0.13\% HI:95 Ol:147 P1:0.78 S1/TOC:3.45

SR Analyzer (SRA -TOC) - TPH TOC Analysis v6.5.113

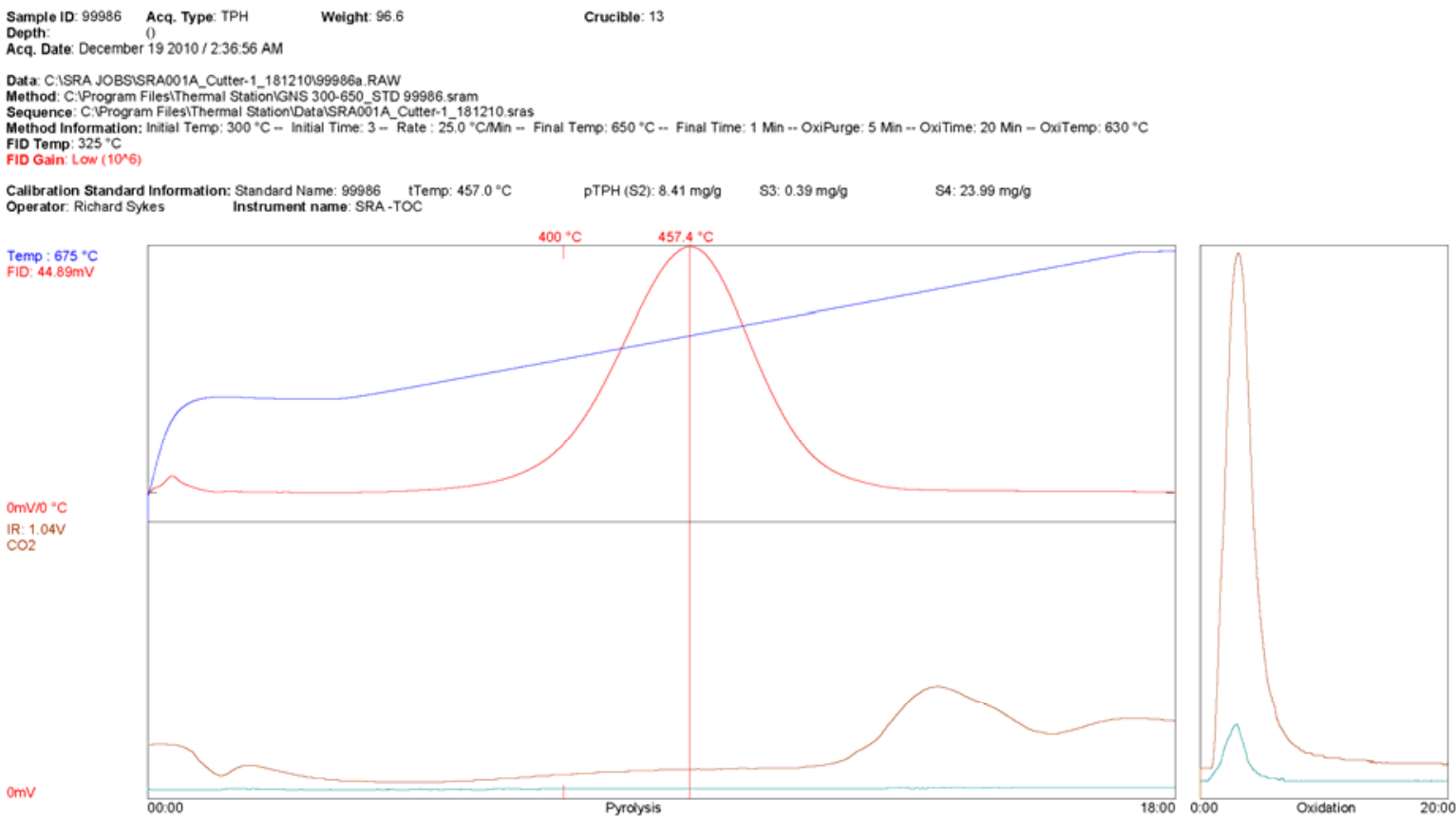

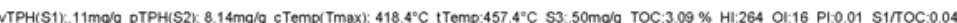




\section{Enclosure 1: Openhole logs}

(See enclosed electronic copy)

Enclosure 2: FullBore MicroImaging Log.

(See enclosed electronic copy)

Enclosure 3: FullBore MicroImaging QC Logs

(See enclosed electronic cop 